\title{
Separation of Depleted Uranium from Soil
}

Steven Larson, John Ballard, Victor Medina,

March 2009

Michelle Thompson, Greg O'Connor, Chris Griggs,

and Catherine Nestler

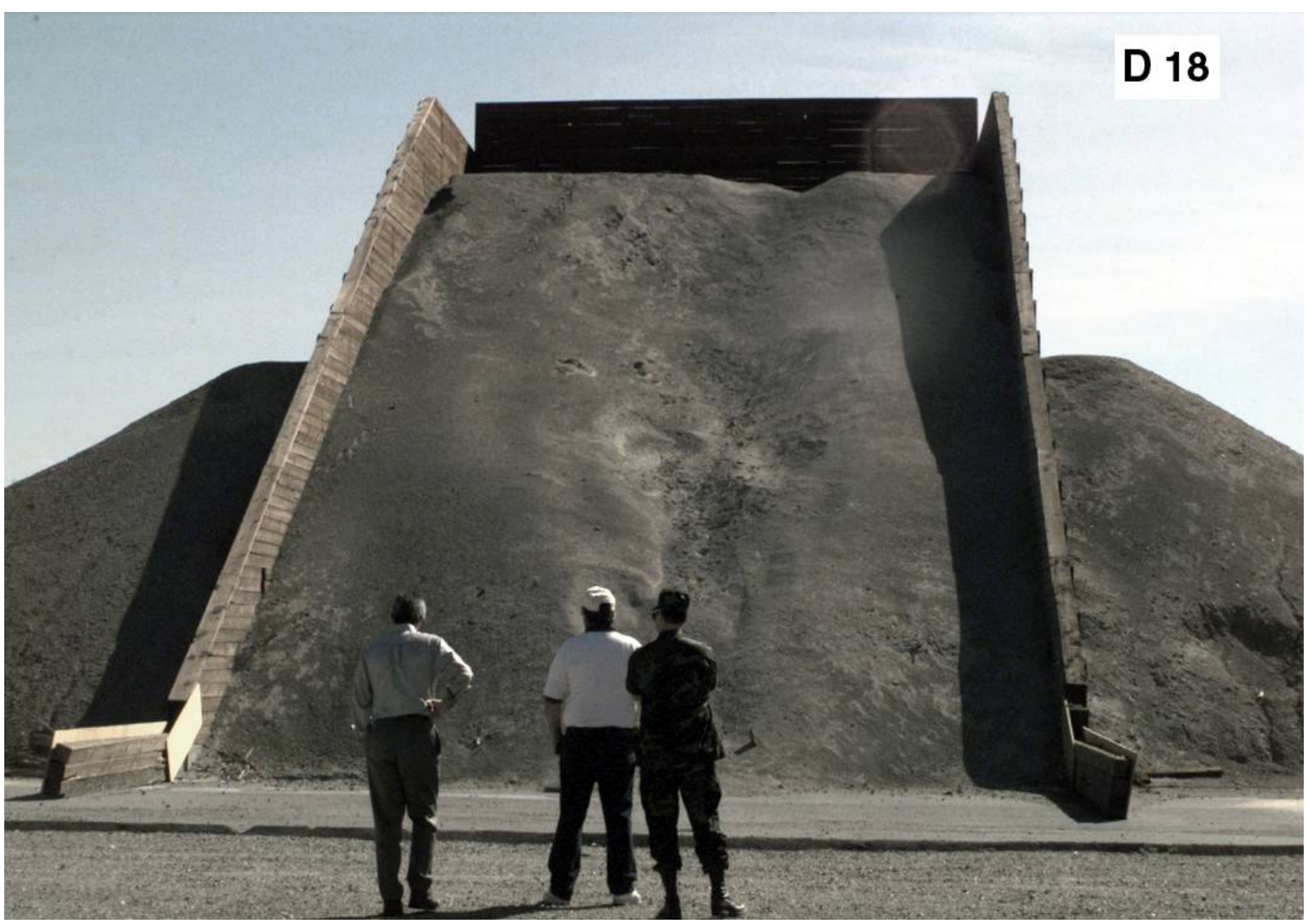




\section{Separation of Depleted Uranium from Soil}

Steven L. Larson, John Ballard, Victor Medina, Chris Griggs

Environmental Laboratory

U.S. Army Engineer Research and Development Center

3909 Halls Ferry Road

Vicksburg, MS 39180-6199

Gregory O'Connor

ARDEC

Picatinny Arsenal, Building 355

NJ 07806-5008

Michelle Thompson, Catherine Nestler

Applied Research Associates, Inc., Southern Division

119 Monument Place

Vicksburg, MS 39180

Final report

Approved for public release; distribution is unlimited.

Prepared for U.S. Army Corps of Engineers

Washington, DC 20314-1000

Under Work Unit 33143

Monitored by U.S. Army Engineer Research and Development Center 3909 Halls Ferry Road, Vicksburg, MS 39180-6199 


\begin{abstract}
Dry and wet physical separation processes were tested at Yuma Proving Ground to remove depleted uranium (DU) from soil. Four sample locations were tested that had varied uranium concentration, weathering, and aging of fired, DU residues. Reduction of soil DU concentration was achieved using simple vibratory or agitated screening techniques. For soils into which the DU had been recently fired, these techniques were successful at removing a large fraction ( $>70$ percent) of the total uranium present (by mass). A heavy liquid separation process based on a water/ sodium polytungstate solution was tested. This produced a sinking fraction that contained nearly 100-percent uranium and uranium oxide by mass for the less weathered soils. However, this type of wet separation is not currently practical for field use. A water-based separation process using an angled vibrating table to facilitate gravity transport of separated DU was also tested. This method produced a fraction of concentrated uranium along with fractions of soil particles with reduced densities. However, this process required extensive particle size separation prior to use and produced a contaminated waste stream that required secondary treatment. The extent to which DU and DU residues could be removed from the Yuma soils depended on the extent of soil weathering and corrosion of the DU alloy.
\end{abstract}

DISCLAIMER: The contents of this report are not to be used for advertising, publication, or promotional purposes. Citation of trade names does not constitute an official endorsement or approval of the use of such commercial products. All product names and trademarks cited are the property of their respective owners. The findings of this report are not to be construed as an official Department of the Army position unless so designated by other authorized documents. 


\section{Contents}

Figures and Tables..........................................................................................................................

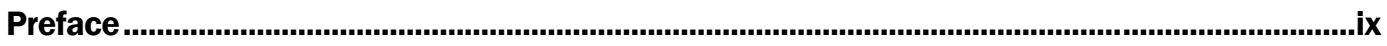

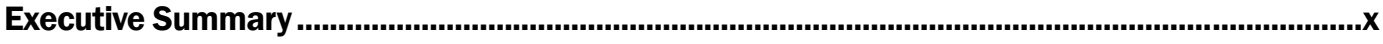

Unit Conversion Factors.......................................................................................................... xii

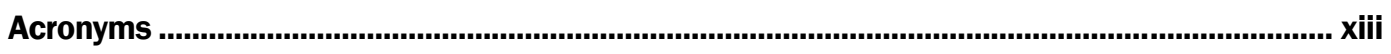

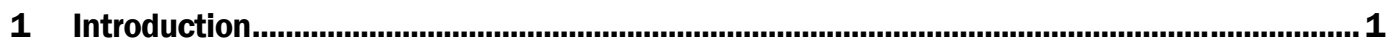

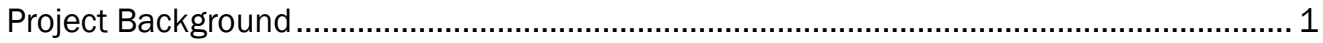

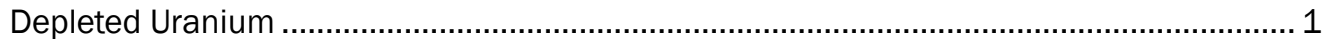

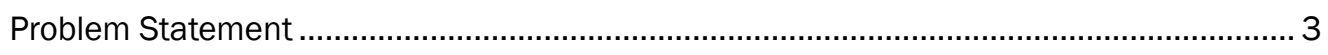

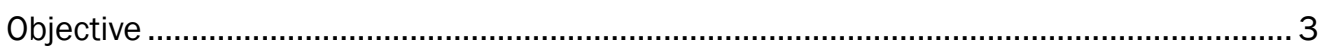

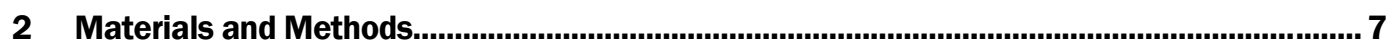

Bulk Soil Collection and Homogenization .................................................................... 7

Initial (Gross) Soil Separation .................................................................................. 9

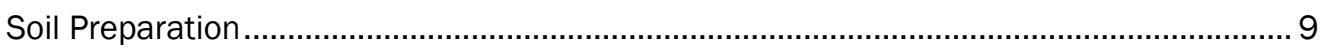

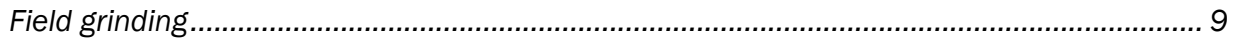

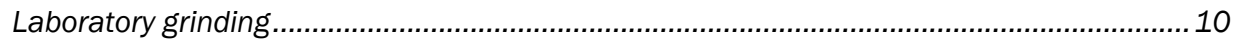

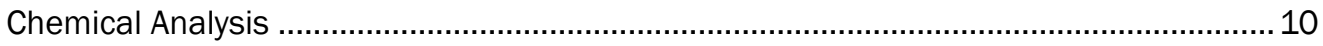

Sequential Extraction Leaching Analysis ................................................................. 11

Soil Separation Technologies ..................................................................................... 13

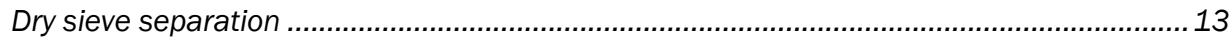

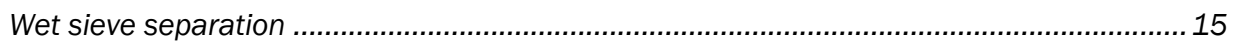

Heavy liquid density separation ........................................................................................ 16

Water/momentum density separation............................................................................. 18

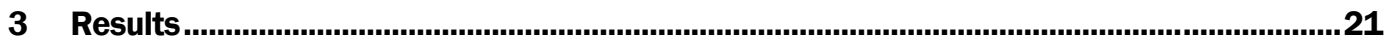

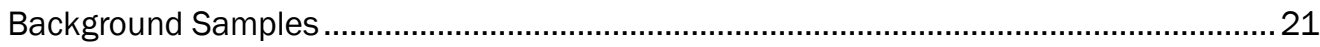

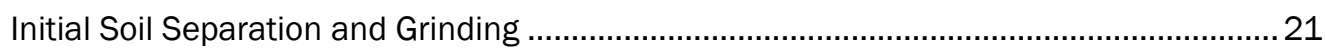

Separation Technologies........................................................................................ 28

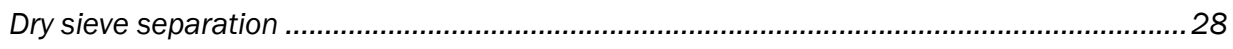

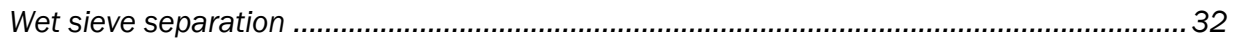

Heavy liquid density separation $(H L D S)$....................................................................... 40

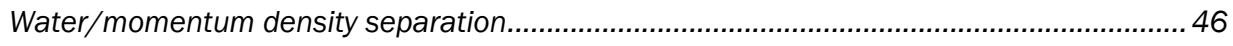

Depleted uranium depth profile in soil .............................................................. 51

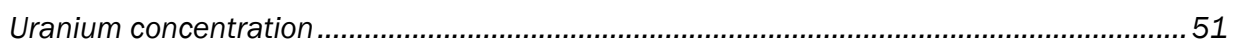

Sequential extraction ......................................................................................................... 52

YPG Site Comparison by Sequential Extraction of Depleted Uranium ................................54 


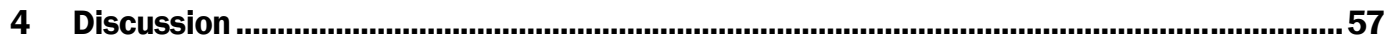

Comparison of DU Concentrations from the Four Sites ................................................57

Comparison of the Effectiveness of Field Grinding and Laboratory Grinding for the

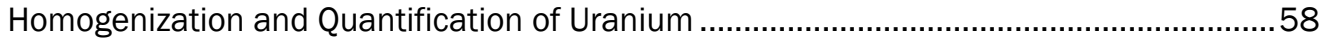

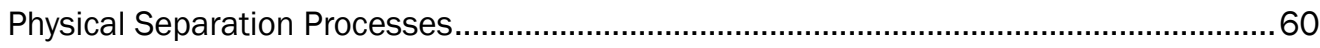

Dry sieve separation for uranium removal: Comparison of three site soils............................ 61

Wet sieve separation for uranium removal: Comparison of four site soils ............................. 65

Heavy liquid density separation for uranium removal: Comparison of four site soils............ 68

Water/momentum density separation for uranium removal: Comparison of three site soils

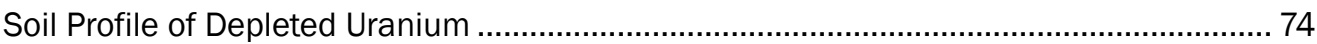

Comparison of DU forms from Various YPG Sites............................................................. 75

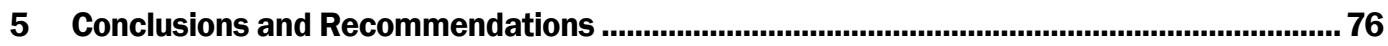

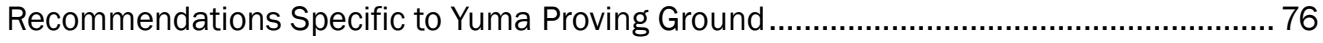

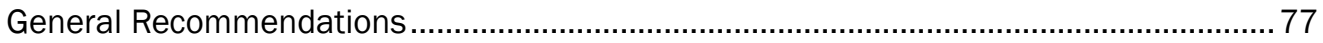

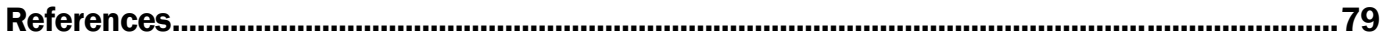

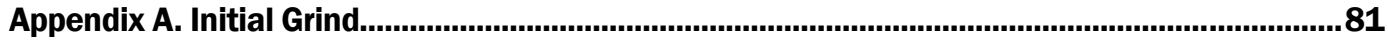

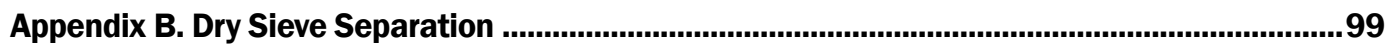

Appendix C. Wet Sieve Separation ...............................................................................117

Appendix D. Heavy Liquid Density Separation.......................................................................... 139

Appendix E. Water/Momentum Density Separation (Wilfley Table)......................................... 164

Report Documentation Page 


\section{Figures and Tables}

\section{Figures}

Figure 1. Comparison of weathered and unweathered depleted uranium rods illustrating the formation of uranyl oxides and salts.

Figure 2. A DU Catch Box at Yuma Proving Ground, Yuma, Arizona. ................................................... 4

Figure 3. Mixing large soil samples prior to sub-sampling and grinding........................................... 8

Figure 4. Summary of samples collected for soil separation testing. ........................................... 8

Figure 5. The BICO UD Direct Driven Disk Pulverizer.......................................................................... 10

Figure 6. SWECO Vibro-Energy round soil separator used for dry sieve operations ......................... 14

Figure 7. The wet sieve operation employed at YPG ....................................................................... 16

Figure 8. Schematic of the heavy liquid density separation process................................................ 18

Figure 9. The soil fractions produced by filtration of the heavy liquid solution................................ 18

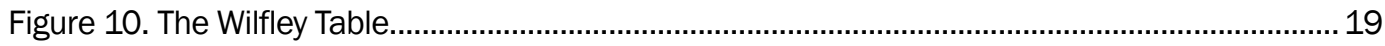

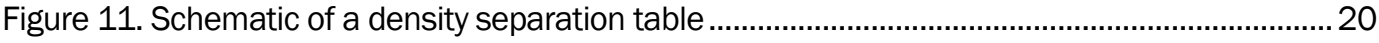

Figure 12. Field operation of the Wilfley Table showing the arrangement of the buckets collecting separation water with the various density fractions of soil..

Figure 13. An example of the appearance of the size fractions obtained through dry sieving. These are the four size fractions obtained from a DU Garden soil sample.

Figure 14. An example of the appearance of soil fractions obtained through wet sieving of Range 20 and DU Garden soil samples. Sieve number and soil particle sizes are indicated above the pans.

Figure 15. Size fractions obtained through HLDS. These fractions are from a Catch Box soil sample. Note the yellow particles in the bottom fraction.

Figure 16. Size fractions obtained by Wilfley Table separation of a Catch Box soil sample identified from smallest density to the greatest density fraction by bucket (Bucket 1 to Bucket 5, respectively).

Figure 17. The uranium concentration in sequential extraction fractions of the YPG DU Garden soil, Lifts 4 and 5, from 9- to 15-in. bgs

Figure 18. Results of the sequential extraction of DU from soil obtained from different test areas of the Yuma Proving Ground.

\section{Tables}

Table 1. Sample collection areas at Yuma Proving Ground, Yuma, AZ. ............................................. 7

Table 2. Analysis procedures for depleted uranium in YPG soil....................................................... 11

Table 3. Sequential extraction method .............................................................................................. 12

Table 4.Sieve sizes used in the comparison of physical separation processes for the Yuma Proving Ground soils

Table 5. Specific sieve sizes and particle sizes of fractions collected during the dry sieve process. 
Table 6. Specific sieve sizes and particle sizes of fractions collected during the wet sieve separation of the Retention Pond soil..

Table 7. Masses of soil and uranium in the $>4.76-\mathrm{mm}$ size fraction of soil collected from the Catch Box area, the Retention Pond, Range 20, and the DU Garden at YPG.

Table 8. Total uranium concentration in the $<4.76-\mathrm{mm}$ size fraction of the Catch Box soils, field grind.

Table 9. Total uranium concentration in the $<4.76-\mathrm{mm}$ size fraction of the Catch Box soils, laboratory grind.

Table 10. Total uranium concentration in the $<4.76-\mathrm{mm}$ size fraction taken from the

Retention Pond, field ground.

Table 11. Total uranium concentration in the $<4.76-\mathrm{mm}$ size fraction of the sample taken from the Retention Pond, laboratory ground.

Table 12. Total uranium concentration in the $<4.76-\mathrm{mm}$ size fraction of the Range 20 soils, field ground.

Table 13. Total uranium concentration in the $<4.76-\mathrm{mm}$ size fraction of the Range 20 soils, laboratory ground.

Table 14. Depth (bgs) and soil mass associated with the excavation of a buried penetrator rod from the DU Garden.

Table 15. Total uranium concentrations in the $<4.76-\mathrm{mm}$ size fraction of the five depth range samples obtained during the excavation of a penetrator rod buried at $30.48 \mathrm{~cm}$ (12 in. bgs) in the DU Garden, field ground.

Table 16. Total uranium concentrations in the $<4.76-\mathrm{mm}$ size fraction of the five depth range samples obtained during the excavation of a penetrator rod buried at $30.48 \mathrm{~cm}$ (12 in. bgs) in the DU Garden, laboratory ground.

Table 17. Concentration of uranium and percent of total uranium in each of the four field ground size fractions of the Catch Box soils obtained through dry sieving separation and field grinding.

Table 18. Concentration of uranium and the percent of the total uranium in each of the four field ground size fractions of the Range 20 soils obtained through dry sieving separation and field grinding.

Table 19. DU Garden excavation of a 12-in. penetrator rod and the soil concentration and percent mass of uranium in 7.62-cm (3-in.) increments of field ground fractions obtained by dry sieve separation and field grinding.

Table 20. Concentration and percent of the total uranium in the different size fractions of soil from wet sieve separation of Catch Box soil samples...

Table 21. Concentration and percent of the total uranium in the different size fractions of soil from the Retention Pond determined through Wet Sieve separation.

Table 22. Uranium concentration and percent of the total uranium in the different size fractions of soil from Range 20 as determined through wet sieve separation.

Table 23. Concentration and percent of the total uranium in the different size fractions of soil from the five excavation depths of an intact DU rod buried at $12 \mathrm{in.}(22.86 \mathrm{~cm})$, determined through wet sieve separation.

Table 24. Concentration of uranium and the percentage of total uranium in each density fraction determined by heavy liquid density separation (HLDS) of soil from the Catch Box site 
Table 25. Concentration of uranium and the percentage of total uranium in each density fraction determined by heavy liquid density separation (HLDS) and laboratory grinding of soil from the Retention Pond site..

Table 26. Concentration of uranium and the percentage of total uranium in each density fraction determined by heavy liquid density separation (HLDS) of soil from the Range 20 sites.

Table 27. Concentration of uranium and the percentage of total uranium in each density fraction from each soil lift as determined by heavy liquid density separation (HLDS) of soil from the DU Garden site

Table 28. Uranium concentration in soil size fractions determined by Wilfley Table density separation of the $<0.841-\mathrm{mm}$ to $>0.297-\mathrm{mm}$ size fraction of the Catch Box 1 composite soil sample.

Table 29. Uranium concentration in soil size fractions determined by Wiffley Table density separation of the $<0.297-\mathrm{mm}$ size fractions of the Catch Box 1 composite soil sample.

Table 30. Uranium concentration in soil size fractions determined by Wilfley Table water/momentum separation of the $<0.841-\mathrm{mm}$ to $>0.297$ - $\mathrm{mm}$ size fraction of the Range 20 composite soil samples.

Table 31. Uranium concentration in soil size fractions determined by Wilfley Table density separation of the $<0.297-\mathrm{mm}$ size fractions of the Range 20 composite soil sample.

Table 32. Uranium concentration in soil size fractions determined by Wilfley Table water/momentum density separation of the $<0.841-\mathrm{mm}$ to $>0.297-\mathrm{mm}$ size fraction of the 30.48- to 8.10-cm (12- to 15-in.) lift collected at the DU Garden ..

Table 33. Uranium concentration in soil size fractions determined by Wilfley Table water/momentum separation of the $<0.297-\mathrm{mm}$ size fractions of the 30.48- to 38.10-cm

(12- to 15-in.) lift collected at the DU Garden.

Table 34. Geiger counter readings of the depth profile of the DU Garden core.

Table 35. Depth profile of uranium obtained from the DU Garden sampling site

Table 36. Sequential extraction for depleted uranium through the depth profile of the soil core taken from the DU Garden sampling site.

Table 37. Average concentration of uranium in each of the SE fractions from different sampling areas of the YPG vs. sum of the fractions

Table 38. Comparison of uranium concentration in the $>4.76-\mathrm{mm}$ soil fraction of the YPG soils..

Table 39. Comparison of the uranium concentration in the $<4.76-\mathrm{mm}$ soil particle size fraction, determined by either field or laboratory grinding, of the soil sampled from the Catch Box and Range 20.

Table 40. Summary of uranium mass in dry sieve size fractions from three YPG sites, and the percentage of total uranium in each fraction

Table 41. Distribution of uranium according to soil particle size achieved by wet sieve separation of Catch Box, Range 20, and DU Garden soil samples.

Table 42. Comparison of uranium distribution in soil size fractions produced by dry and wet sieve separation.

Table 43. Distribution of uranium according to soil particle density achieved by heavy liquid density separation of Catch Box, Range 20, DU Garden and Retention Pond soils.

Table 44. Distribution of uranium according to soil particle size and density achieved by Wilfley Table water/momentum separation of Catch Box, Range 20, and DU Garden soils in the $0.841-\mathrm{mm}$ to $0.297-\mathrm{mm}$ size range. 
Table 45. Distribution of uranium according to soil particle size and density achieved by Wifley Table water/momentum separation of Catch Box, Range 20, and DU Garden soils in the $<0.297-\mathrm{mm}$ size range... 


\section{Preface}

This report was prepared as part of the Congressional Interest Training Range Sustainment Program; Depleted Uranium Sensing, Containment, and Removal Focus Area. The work was funded by MIPR6FNC005521 and conducted under Contract No. W912HZ-06-C-0032, Purchase Request No. W81EWF61607208, titled, "Technical Assistance for the Locating and Retrieving of Expended Depleted Uranium Munition." Research was conducted by the U.S. Army Engineer Research and Development Center (ERDC)-Environmental Laboratory (EL), Vicksburg, MS, and Mississippi State University-Institute for Clean Energy Technology (MSU-ICET), under the sponsorship of the U.S. Army Armament, Research, Development and Engineering Center (ARDEC), Picatinny Arsenal and the U.S. Army ARDEC Program Executive Office for Ammunition, Heavy Metals Office, Picatinny Arsenal.

This project was performed under the general supervision of Dr. M. J ohn Cullinane, Jr., Technical Director, Military Environmental Engineering and Sciences, EL; J ohn H. Ballard, Office of Technical Director and DU Program Manager, EL; and Dr. Steve L. Larson, Lead Principal Investigator, EL. In-house review was provided by Mr. W. A. Martin, Chief, Environmental Engineering Branch and Ms. Susan Bailey, Environmental Engineering Branch. We gratefully acknowledge the field assistance of Mr. Marvin Unger, Public Works, and the staff of the Yuma Proving Ground.

This study was conducted under the direct supervision of Mr. W. Andy Martin, Branch Chief, EP-E, and under the general supervision of Dr. Richard E. Price, Division Chief, EPED, and Dr. Elizabeth C. Fleming, Director, EL.

COL Gary E. J ohnston was Commander and Executive Director of ERDC. Dr. J ames R. Houston was Director. 


\section{Executive Summary}

Dry and wet physical separation processes were tested at Yuma Proving Ground (YPG) to recover residuals of fired depleted uranium (DU) from contaminated soils from four locations with varied degrees of uranium concentration, weathering, and aging. At the four locations, the DU munitions used for testing were penetrator ordnance of varying sizes. The uranium present in the soils consisted of metallic DU as well as uranium corrosion products, and the products of dissolution of those uranium oxides. Metallic DU, uranium oxides, and solid uranium salts have a higher density than most soil constituents. The extent to which DU and DU residues from kinetic penetrators could be removed from the YPG soils depended on the extent of weathering the soils had undergone during the period between firing and attempted separation.

Dry separation of DU fragments from the surrounding sand was successfully and inexpensively achieved using simple vibratory or agitated screening techniques. For soils into which the DU had been recently fired (i.e. the Catch Box soil), these techniques were successful at removing greater than 70 percent of the total uranium present (by mass). In soils in which long periods of time had passed since firing, or that had been heavily weathered, the removal efficiency of this technique was somewhat lower; approximately 50 percent of the $>4.76-\mathrm{mm}$ soil size fraction of DU Garden deep lifts and 16 percent of the $>4$.76- $\mathrm{mm}$ soil size fraction of the Range 20 soil, and no uranium was removed from the Retention Pond soil using a 4.76-mm dry sieving process.

A heavy liquid density separation system was developed, based on a water/ sodium polytungstate solution, to remove uranium salts and oxides from soil. This produced a sinking fraction that contained nearly 100 percent uranium and uranium oxide by mass for the less weathered soils. However, due to the expense, this type of heavy liquid separation is not currently practical for field use. Another approach for the removal of uranium salts and oxides from soils was a water-based separation process using an angled vibrating table to facilitate gravity transport of separated DU. This method produced a fraction of concentrated uranium along with fractions of soil particles with reduced densities. However, this process was shown to require extensive particle size separation prior to use for a 
number of the YPG soils and produced a contaminated waste stream of separation water that required secondary treatment. Wet separation procedures had the advantage of separating the fine uranium oxides observed in soils impacted with DU rounds from the less dense soils. The solubilities of these oxides also resulted in significant levels of dissolved uranium in the separation waters. Techniques such as ion exchange filtration and zero valent iron or titanium oxide filtration might be applicable for dealing with water containing dissolved uranium. The fine soil particles, although separated from the uranium metal and uranium oxides, were noted to contain large concentrations of uranium that had adhered to these particles as uranium ions.

Recommendations for management of DU at YPG are regular removal of DU fragments from the sand bed using dry separation techniques in order to remove the metallic DU present in these soils. This procedure would reduce the amount of time that metallic uranium could undergo corrosion and weathering as well as mediate any risks associated with the pyrophoric combustion of metallic DU in the impact area. Smaller particulates containing metallic uranium, uranium oxides, or soil particles associated with uranium would remain in the soil. For this reason, dust abatement technologies might be useful for reducing the spatial distribution of uranium on the range. 


\section{Unit Conversion Factors}

\begin{tabular}{|l|l|l|}
\hline Multiply & By & To Obtain \\
\hline gallons (U.S. liquid) & $3.785412 \mathrm{E}-03$ & cubic meters \\
\hline inches & 0.0254 & meters \\
\hline pounds (mass) & 0.45359237 & kilograms \\
\hline square miles & $2.589998 \mathrm{E}+06$ & square meters \\
\hline
\end{tabular}




\section{Acronyms}

$\begin{array}{ll}\text { ARTP } & \text { Army Range Technology Program } \\ \text { bgs } & \text { below ground surface } \\ \text { DU } & \text { Depleted uranium } \\ \text { EL } & \text { Environmental Laboratory } \\ \text { ERDC } & \text { Engineer Research and Development Center } \\ \text { ICP-MS } & \text { Inductively coupled plasma mass spectroscopy } \\ \text { ICP-OES } & \text { Inductively coupled plasma optical emission spectros- } \\ & \text { copy } \\ \text { MS } & \text { Mass spectrometry } \\ \text { MSU-ICET } & \text { Mississippi State University - Institute for Clean En- } \\ & \text { ergy Technology } \\ \text { PEO-AMMO } & \text { The Army Program Executive Office for Ammunition } \\ \text { SE } & \text { Sequential extraction } \\ \text { XRD } & \text { X-ray diffraction } \\ \text { YPG } & \text { Yuma Proving Ground }\end{array}$




\section{Introduction}

\section{Project Background}

The U.S. Army Engineer Research and Development Center (ERDC)Vicksburg, Mississippi, executed the Army Range Technology Program (ARTP) research program with the Mississippi State University-Institute for Clean Energy Technology (MSU-ICET) under the sponsorship of the Program Executive Office for Ammunition (PEO-AMMO), Picatinny Arsenal and a Congressional Interest training range sustainment program. The objective of the ARTP was to develop and evaluate technologies for the detection and separation of depleted uranium (DU) penetrator projectiles and uranium oxide compounds from Catch Box and training range soils. The technologies under development are designed to provide engineered solutions that allow sustainable use of DU at test ranges.

Originally established in 1943, the Yuma Proving Ground (YPG) is a test facility for the US Army, managing testing in three different environmental extremes. The Yuma Test Center in Yuma, AZ serves as the arid environment testing facility, encompassing approximately 1,300 square miles. The YPG was selected as the research site because of the diversity in age and weathering of the DU in this area.

\section{Depleted Uranium}

The chemical toxicity of DU in soil has raised health concerns world-wide due to its military deployment (Bleise et al. 2003, Burkart et al. 2005, Giannardi and Domenici 2003, McLaughlin 2005) as well as widespread civilian uses (Betti 2003, Hamilton 2001). This concern has generated interest in the remediation of soils contaminated with DU in the course of combat operations, as well as sustainable use of DU weapons testing ranges in this country. Unique approaches are required due to the radiological, toxic heavy metal, and pyrophoric hazards associated with the use of metallic uranium.

The specific gravity of uranium is $18.95 \mathrm{~g} / \mathrm{cm}^{3}$, while that of rock/ soil/sand can vary, but can be approximated at 1.5 to $2.5 \mathrm{~g} / \mathrm{cm}^{3}$. Uranium oxidizes as it weathers, producing uranyl oxides and salts, evident as black and yellow coatings on the solid surface (Mellini and Riccobono 
2005; Figure 1). The black substance has been identified by X-ray diffraction (XRD) analysis as uraninite, $\mathrm{UO}_{2}$. A possible further oxidation product was tentatively identified as $\mathrm{U}_{3} \mathrm{O}_{8}$ (Mellini and Riccobono 2005). The amorphous yellow coating is composed of uranyl ions, and hydroxyl compounds and/ or water, producing a compound that is possibly schoepite, $\mathrm{UO}_{3} \cdot 2 \mathrm{H}_{2} \mathrm{O}$ (Mellini and Riccobono 2005). These compounds have relatively high solubility in water (Meinrath et al. 2003). The density of uranium oxide is $10.96 \mathrm{~g} / \mathrm{cm}^{3}$, making gravimetric separation of these corrosion products of DU residues separable by density from soil. However, the uranium oxides have significant solubility in water and the resulting ionic uranium can form uranium-based salts with lower densities as well as sorb to clays and organic matter in soil and form complexes with soil particles (J ohnson et al. 2004, Dong et al. 2006, Choy et al. 2006).

Certain metals, including uranium, are referred to as pyrophoric (combustible) metals because of the ease of ignition when they reach a high specific area ratio (as thin sections, fine particles, or molten states). Uranium in finely divided form is readily ignitable. Uranium also has an increased tendency to burn after prolonged exposure to moist air. A few metals, such as thorium, uranium, and plutonium, emit ionizing radiation that, when ignited, can complicate fire fighting and introduce a radioactive contamination problem. Under a dry, slightly oxidizing atmosphere, however, uranium corrodes quiescently. The heat generated from slow corrosion is not sufficient to ignite the uranium.

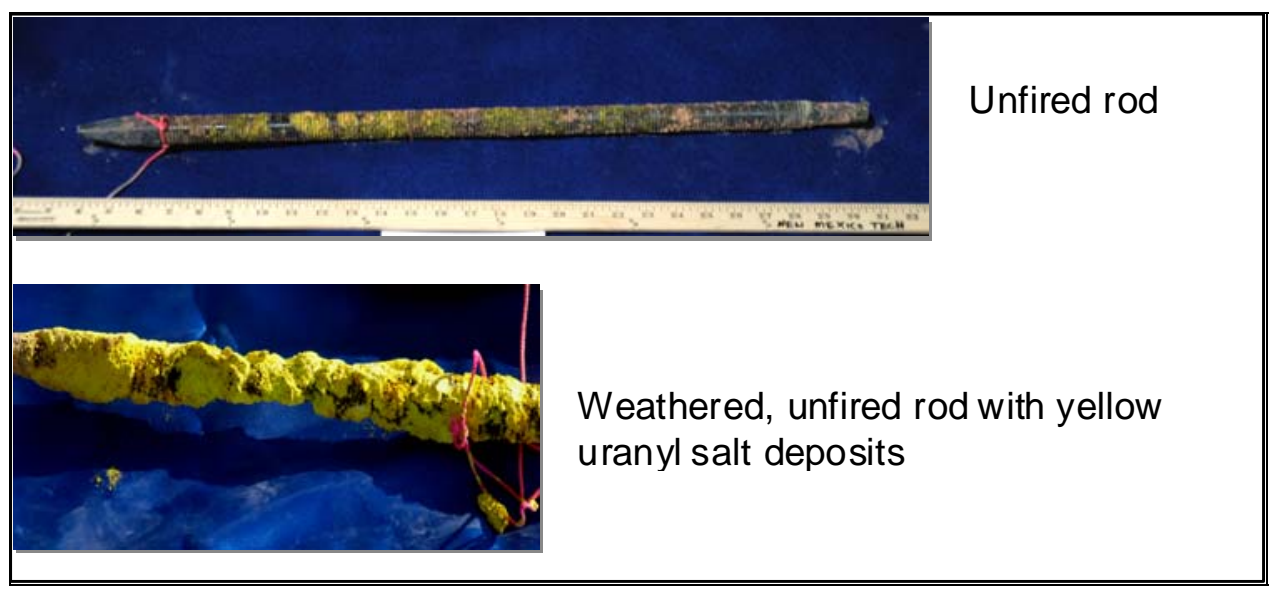

Figure 1. Comparison of weathered and unweathered depleted uranium rods illustrating the formation of uranyl oxides and salts. 


\section{Problem Statement}

This research addresses the following concerns associated with the use of Catch Boxes for testing with depleted uranium munitions:

1. Movement of uranium from the impact area (Catch Box).

2. Accumulation of large masses of metallic uranium in the impact area, presenting a risk for the occurrence of a sustained phyrophoric reaction.

Currently, when maintenance is performed on DU firing ranges, large volumes of range soil or berm material are excavated and shipped to a hazardous material or low-level radiation disposal site. From an operational perspective this approach is hindered by the high cost associated with such activities, the potential for exposure of personnel performing excavation, containerization and transport of the material, and disruption of range use during the operation.

The removal of depleted uranium from firing ranges varies from:

- Collection and storage of freshly fired DU penetrators,

- Removal of the uranium oxide residues that result from the aging of DU projectiles in soils,

- Removal of soil containing uranium residues for bulk disposal.

Technologies are needed to reduce the mass of metallic DU in the impact area as well as reduce the amount of uranium associated with the fine portions of the soil as uranium oxides, uranium salts, or soil particles loaded with uranium ions. This will reduce or eliminate the large disposal costs of soils associated with low-level radioactivity. Disposal costs can be further reduced if the DU metal-free soil is returned to its original site on the firing range assuming all legal and regulatory requirements for returning soils have been met.

\section{Objective}

Research focused on the effectiveness of physical separation technologies for uranium removal from four dissimilar soils impacted by testing of DU penetrators. Physical separation processes, used frequently for both maintenance and remediation of heavy metals where metal particles are present, are based on soil particle characteristics such as size, shape, density and/ or magnetism (Larson et al. 2007b). The specific processes used for 
separation of uranium from the four site soils at YPG included size separation, through both wet and dry sieving, and density separation using either heavy liquid or water.

When combined with improved, rapid detection methods for DUcontaminated areas, by separating the DU from the uncontaminated soil, a significant volume reduction for hazardous material disposal can be achieved resulting in considerable cost savings in DU life-cycle management.

Research was conducted at several areas within the YPG; Range 20, the DU Catch Box (Figure 2), the retention pond for runoff water from the Catch Box, and an excavation area known as the "DU Garden." The DU Garden was an experimental area prepared in 2003/2004. In this area, fired and unfired penetrator rods were buried in rows at several depths

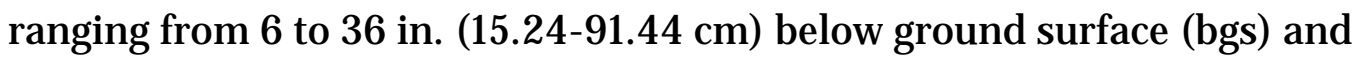
allowed to weather. These four areas represent a wide range of weathering times and processes present at YPG.

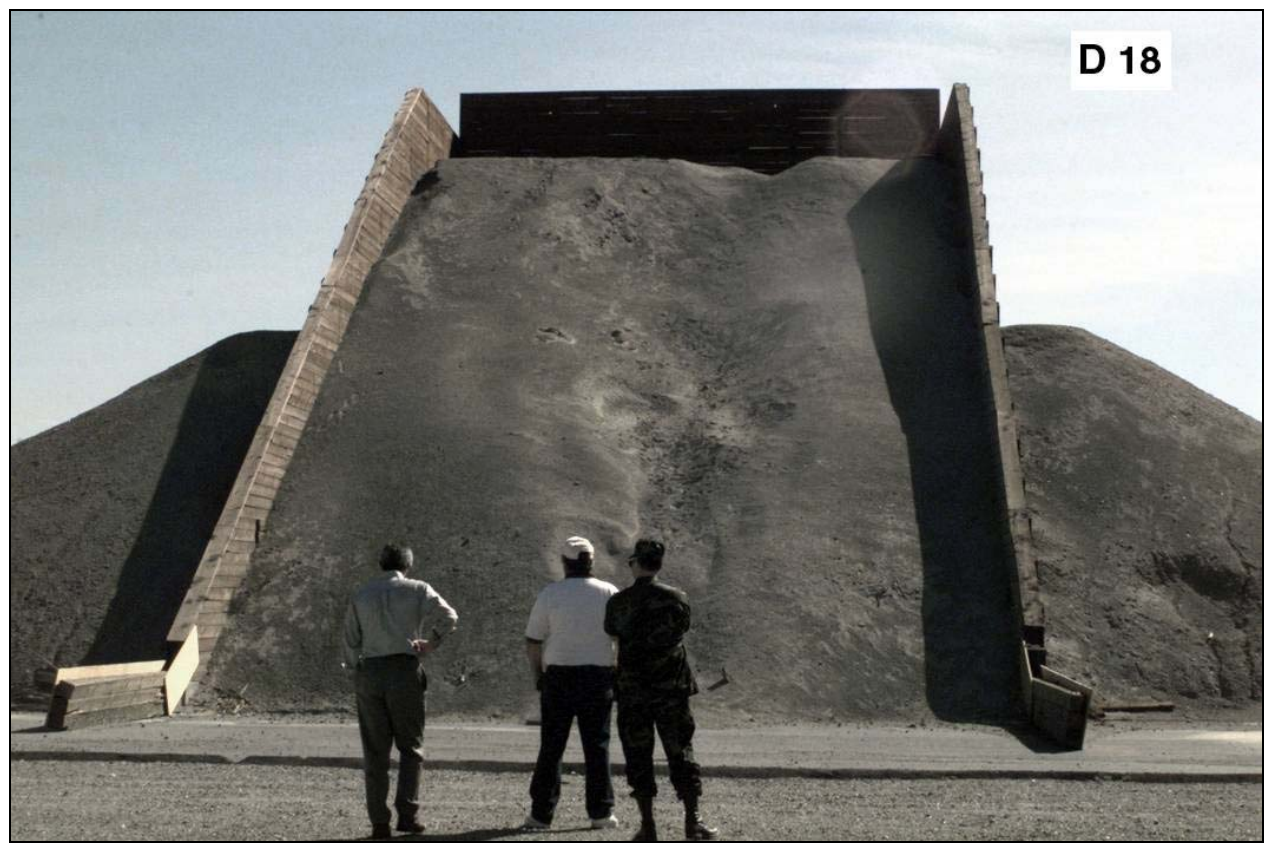

Figure 2. A DU Catch Box at Yuma Proving Ground, Yuma, Arizona.

The samples obtained from the Catch Box represent the least weathered area. The Catch Box was recently excavated with the soil being removed and disposed of as radioactive waste. The soil material that was used to replace the excavated soil was not native YPG soil but rather construction 
sand trucked in to the Catch Box. Since that maintenance, the Catch Box was used for a series of tests in which large caliber, long rod penetrators were fired into the replacement soil. As such, it provides a soil in which weathering of the DU metal occurred over a period of less than 2 years. This provided a means of evaluating separation technologies that mimic most closely the types of impact area maintenance approaches that might be used on a periodic basis for removal of metallic DU residues.

The DU Garden represents a situation where the penetrators were weathered for up to six years in the subsurface. This soil type and the effectiveness of particle size and density separations of DU residues from soils with these weathering conditions provided an opportunity to evaluate separation approaches for less frequent removal of DU residues from YPG soils.

The material excavated from the retention pond below the Catch Box differed from the other three sites because it did not have intact penetrators or clearly observable metallic DU particles. The retention pond area is a lined surface water runoff collection and settling area. When rain events do occur, water laden with suspended soils runs out of the Catch Box, onto the apron area, and down into the retention pond. The water is held there and evaporation takes place over time leaving the resulting sediment as a dry layer on the bottom of the basin. The depth of sediment in the basin varied from 3 to $9 \mathrm{in}$. and has not been previously removed. This sediment contained fine material that leaves the Catch Box, along with solubilized uranium. During the saturated period, when evaporation is the mechanism for water removal, settling of solids occurs along with potential dissolution of any soluble uranium forms. As the area becomes free of water, these soluble species interact with the solids at the bottom of the retention pond. They form uranium salts of varying solubilities, they sorb to clays and organic matter in soil, and they form complexes with soil particles (Choy et al. 2006, Dong et al. 2007, J ohnson et al. 2004).

The Range 20 area is the first area at YPG where DU rounds were fired. The impact area is widespread and consists of a series of trenches that resulted from the physical disruption due to firing as well as erosion over the 20 years that the range was used for testing of DU penetrators. Soil at this site was directly impacted by DU penetrators and contains residues from DU penetrators. These residues and penetrators have undergone extensive weathering and multiple rain events. In this significant amount of time, 
they have possibly formed uranium oxides, salts, and soil particles containing sorbed uranium species.

The ability to directly compare the removal efficiency of DU residues from the four dissimilar areas provided a means by which to recommend range management practices for sustainable use of DU at YPG. Varied soil types, deposition processes, and weathering times allowed evaluation of the effectiveness of both particle size and density separation technologies for uranium removal. 


\section{Materials and Methods}

\section{Bulk Soil Collection and Homogenization}

Four locations were sampled at the YPG (Table 1), as well as an uncontaminated area. The four sites provided a variety of soil/ DU systems for comparison. The uncontaminated area provided background (control) data.

Table 1. Sample collection areas at Yuma Proving Ground, Yuma, AZ.

\begin{tabular}{|l|l|l|l|l|}
\hline Site & Description & DU Age & Comment & $\begin{array}{c}\text { Bulk } \\
\text { Samples }\end{array}$ \\
\hline Catch Box & Low DU & 18 months & $\begin{array}{l}\text { Used for prove out of 105-mm and } \\
\text { 120-mm ammunition }\end{array}$ & $\begin{array}{l}\text { 3, 25-Kg } \\
\text { samples }\end{array}$ \\
\hline $\begin{array}{l}\text { Catch Box } \\
\text { retention } \\
\text { pond }\end{array}$ & $\begin{array}{l}\text { Runoff water } \\
\text { from the Catch } \\
\text { Box }\end{array}$ & $\begin{array}{l}\text { Unknown } \\
\text { number of } \\
\text { years }\end{array}$ & $\begin{array}{l}\text { Fine sediment only. Total DU disso- } \\
\text { lution and precipitation }\end{array}$ & $\begin{array}{l}\text { 1, 25-Kg } \\
\text { sample }\end{array}$ \\
\hline $\begin{array}{l}\text { DU Garden } \\
\text { Excavation } \\
\text { samples }\end{array}$ & $\begin{array}{l}\text { Intact penetra- } \\
\text { tors }\end{array}$ & 5 years & $\begin{array}{l}\text { Buried at depths that ranged from } \\
\text { - to 36-in. bgs (15.5 cm to 91.4 } \\
\text { cm). A DU rod buried at 12- in. bgs } \\
\text { was selected for study. }\end{array}$ & $\begin{array}{l}\text { 5, 25-Kg } \\
\text { samples }\end{array}$ \\
\hline Range 20 & High DU & $\leq 20$ years & Heavy weathering & $\begin{array}{l}\text { 3, 25-Kg } \\
\text { samples }\end{array}$ \\
\hline
\end{tabular}

The sampling procedure began by selecting areas that appeared representative of the site as a whole. A large volume of soil was removed from the sample site, the quantity dependent on the diameter of the largest piece of soil/ munition residue present on the site (Taggart 1945). This large volume of soil was mixed 12 times in a process that involved 12 splitting and recombining steps (Figure 3 ) and is referred to in this report as the bulk soil sample. The bulk samples from the Catch Box and Range 20 were subsampled by dividing the soil into nine approximately equal areas and filling three 5-gal buckets with soil taken sequentially from each of these nine areas. This resulted in the samples referred to as Catch Box 1, Catch Box 2, and Catch Box 3 and Range 20, 1, 2, and 3. Each of the 5-gal buckets contained $25 \mathrm{Kg}$ of homogenized soil. The Retention Pond soil was already very homogeneous in texture; therefore a single 25-Kg sample was obtained. The soil removal from around the buried penetrators in the DU 
Garden is detailed elsewhere in this report. Briefly, each 3-in. lift bgs was treated as a single sample. The sample collection is summarized in the flowchart in Figure 4.

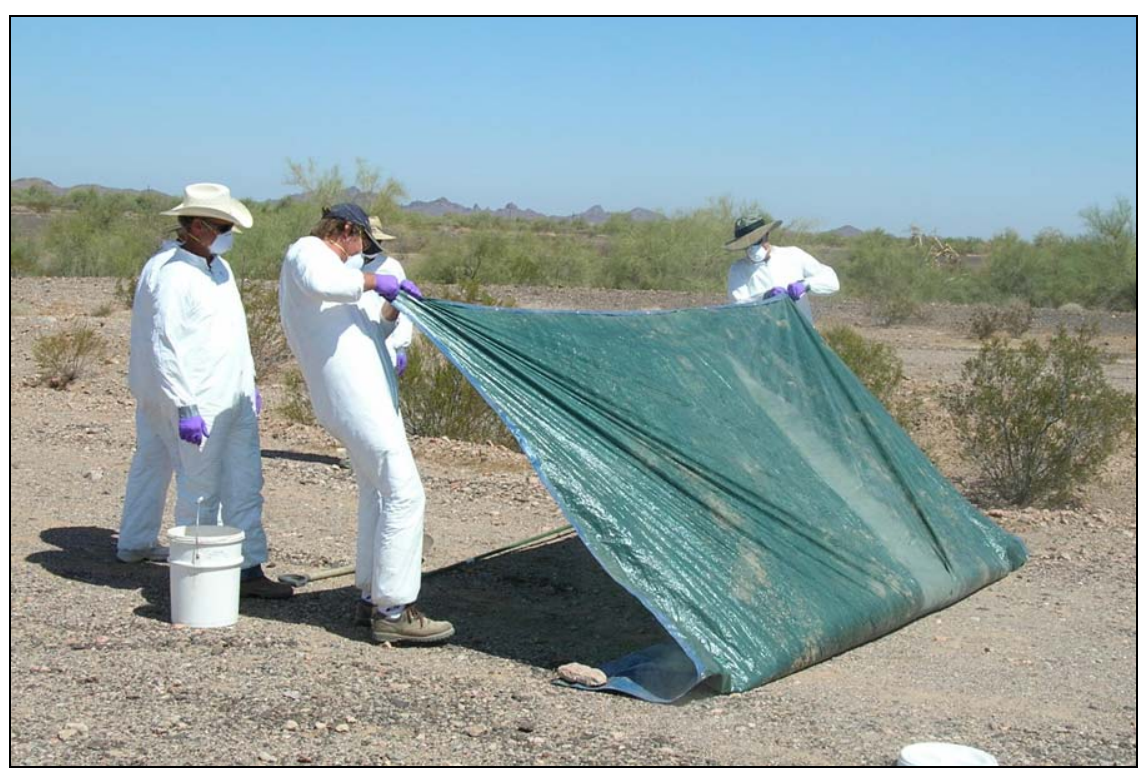

Figure 3. Mixing large soil samples prior to sub-sampling and grinding.

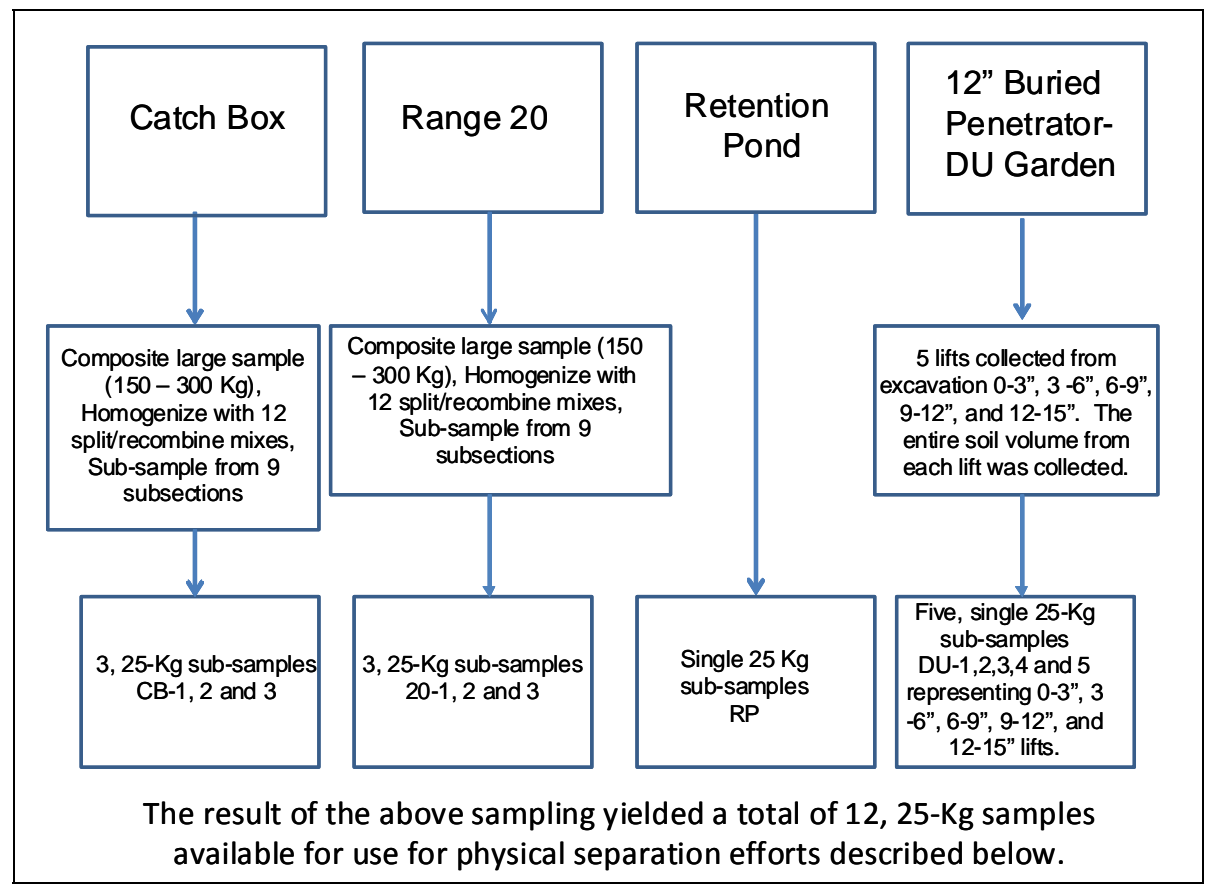

Figure 4. Summary of samples collected for soil separation testing. 
In addition to the bulk samples, soil cores were taken from two areas of the YPG. One set of cores, taken in an uncontaminated area, provided a background study of DU contamination with depth. Cores were also taken from the DU Garden area to prepare a depth profile of DU vertical transport. The cores were taken $38.1 \mathrm{~cm}$ ( $15 \mathrm{in}$.) bgs and were analyzed for DU concentration at 8-cm (3-in.) intervals. The penetrator at the DU Garden was buried at $30.5 \mathrm{~cm}$ ( $12 \mathrm{in}$.) bgs.

\section{Initial (Gross) Soil Separation}

The entire bulk sample was dry sieved using a \#4 mesh sieve $(4.76 \mathrm{~mm})$ in order to separate out the large soil particles and DU fragments. The mass of the soil present in both of these large fractions $(>4.76 \mathrm{~mm}$ and $<4.76 \mathrm{~mm}$ ) was determined. The larger particles were sorted by hand using a field Geiger-Mueller counter in order to obtain the relative amounts of soil and uranium in this large size fraction. The material that passed through the \#4 mesh sieve was ground in the field and sub-sampled for digestion and metals analysis. Additional data from this initial grinding, including concentrations of metals other than uranium, is available in Appendix A for each of the YPG soils.

\section{Soil Preparation}

Metals in soil are known to be distributed heterogeneously. Two methods were tested in an attempt to overcome this heterogeneity, improve the reliability of sample analysis, and reduce analytical costs associated with soil remediation. A sample of each soil was field ground, as described below, and then returned to the laboratory for digestion and analysis. A portion of the field ground soil was ground a second time in the laboratory and then also digested and analyzed. A significant cost savings could be realized for in situ remediation of the depleted uranium-contaminated soils if field grinding alone would yield reliable results.

\section{Field grinding}

In the field, a BICO UD Direct Driven Disk Pulverizer (Figure 5) was used to reduce the soil to fine powder of \#120 mesh size $(0.125 \mathrm{~mm})$ at a rate of approximately $1 \mathrm{lb} /$ minute (based on quartz). The 8-in. ceramic grinding plates were adjusted and locked into position to obtain the required particle size. 

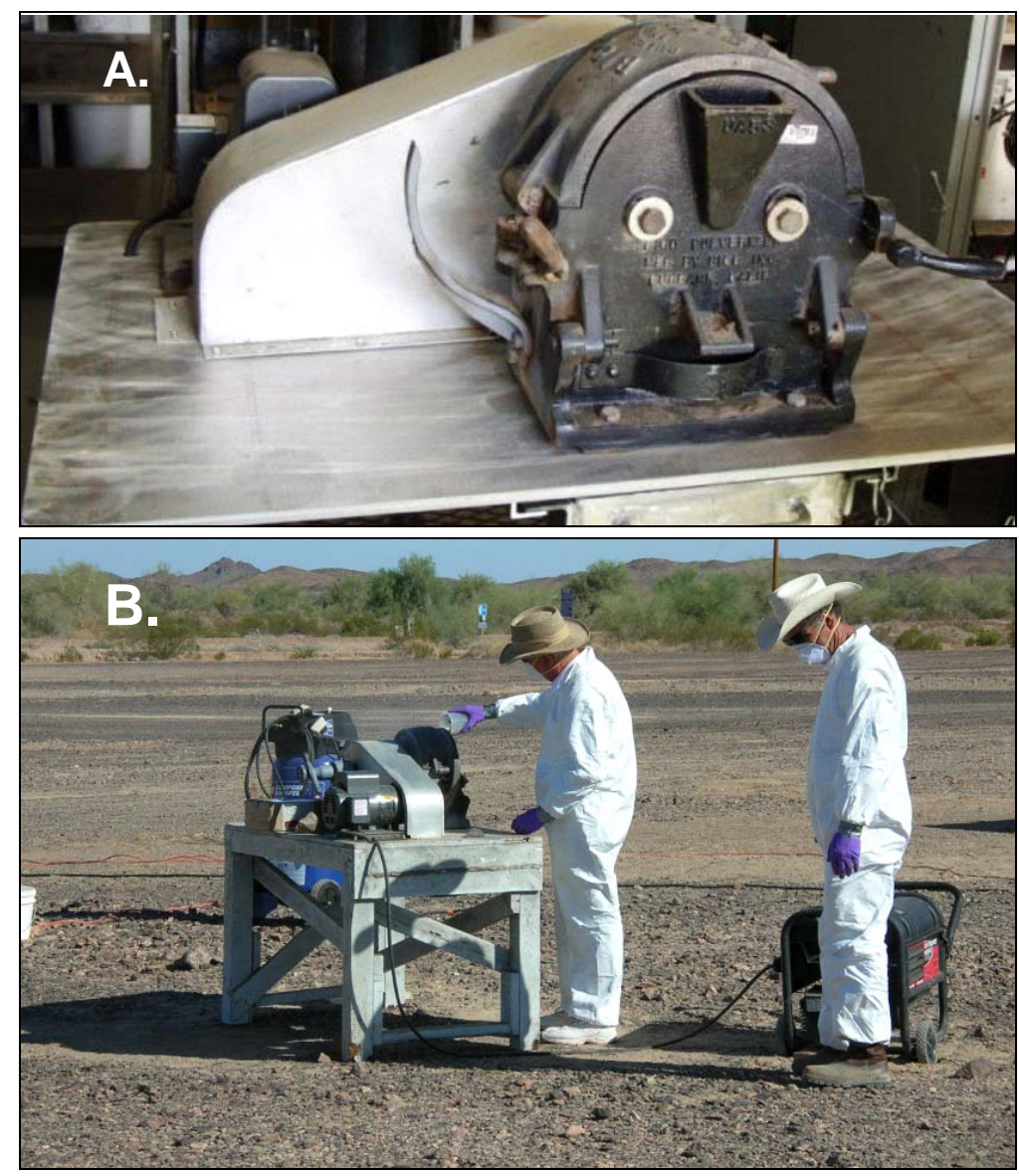

Figure 5. The BICO UD Direct Driven Disk Pulverizer. A. In the laboratory. B. Soil grinding field operation at Yuma Proving Ground.

\section{Laboratory grinding}

Following sieve separation in the field, soil samples were shipped to the ERDC-Vicksburg, MS for metal analysis. Upon arrival at ERDC, the samples were homogenized and sub-samples were taken for a second grinding. These samples were ground using the Fritsch Pulverisette 7 to pass a \#400 mesh sieve $(0.037 \mathrm{~mm})$. All samples were digested and analyzed for metals in triplicate. The concentration of uranium in field-ground samples was compared to the concentration in samples that were ground in the laboratory in order to establish the homogeneity of the field-ground samples.

\section{Chemical Analysis}

Table 2 lists the procedures used during this study for analysis of the $\mathrm{U}$ in soil. Analysis was performed using Inductively Coupled Plasma (ICP) on a Perkins Elmer Optima 3000 or by ICP-Mass Spectrometry (MS) on a Perkins Elmer Sciex 6000. Non-detect values are those that are below the ICP 
reporting limit. For data analysis purposes, the ICP reporting limit, $0.05 \mathrm{mg} / \mathrm{kg}$, was used in place of non-detect. Uranium concentration in the various soil size fractions by the different treatment procedures was reported as the average, standard deviation and percent standard deviation using a 95-percent confidence interval where the sample size $(n=3,5$, or 9) is indicated in the text and in the specific tables (SigmaStat, Systat Software, Inc.).

Table 2. Analysis procedures for depleted uranium in YPG soil.

\begin{tabular}{|l|c|c|}
\hline \multicolumn{1}{|c|}{ Procedure } & Method & Reporting Limit (mg/kg) \\
\hline Soil digestion & SW-846-3051 \\
SW-846-3015 & $\mathrm{na}^{1}$ \\
\hline ICP2 & EPA Method 200.7 & 0.50 \\
\hline 1na=not applicable \\
2ICP=inductively coupled plasma spectrometry
\end{tabular}

\section{Sequential Extraction Leaching Analysis}

In order to study the mineral forms of DU, YPG field soils from each sampling site were evaluated by sequential extraction (SE) analysis. The entire soil fraction that was less than $4.76 \mathrm{~mm}$ in size was used for the extraction. This study used the method reported by Ryan et al. (2001) and Tessier et al. $(1979,1988)$ to separate the soil into five operationally defined fractions (Table 3). The method was modified by reducing the amount of the soil that was extracted. The 1:10 ratio between soil and acid extractant was maintained throughout the procedure. The five fractions are:

1. Exchangeable: includes metals that are reversibly sorbed to soil minerals, amorphous solids, and/ or organic material.

2. Carbonate: made up of metals that are irreversibly sorbed, or otherwise bound in metal carbonate minerals that are removed by mild acid ( $\mathrm{pH} 5$ ) dissolution.

3. Fe-Mn Oxide: comprises the metals bound to hydroxides of iron, manganese and/ or aluminum, which are liberated by an acidic reducing agent.

4. Organic matter and sulfide: consists of any metal associated with sulfide minerals or that are irreversibly bound to organic groups.

5. Residual: consists of the remaining metals that are distributed between the silicates, phosphates, and refractory oxides released by total dissolution of the material. 
Table 3. Sequential extraction method

\begin{tabular}{|c|c|c|}
\hline Sequence & Reagents & Conditions \\
\hline \multirow{6}{*}{$\begin{array}{l}\text { Step 1: } \\
\text { Exchangeable Pb }\end{array}$} & \multirow{6}{*}{$1 \mathrm{M} \mathrm{MgCl}_{2}$} & 1. Weigh $10 \mathrm{~g}$ of soil into a $1000-\mathrm{mL}$ centrifuge bottle \\
\hline & & 2. Add $100 \mathrm{~mL}$ of $1 \mathrm{M} \mathrm{MgCl}_{2}$ solution at $\mathrm{pH} 7$ \\
\hline & & 3. Shake for $1 \mathrm{hr}$ \\
\hline & & 4. Centrifuge at $2000 \mathrm{rpm}$ for 30 minutes \\
\hline & & 5. Filter supernatant using 0.45 -micron filter \\
\hline & & 6. Collect filtrate, label “Exchangeable” \\
\hline \multirow{5}{*}{$\begin{array}{l}\text { Step2: } \\
\text { Lead Carbonates }\end{array}$} & \multirow{5}{*}{$1 \mathrm{M} \mathrm{NaOAc}$} & $\begin{array}{l}\text { 1. To residue from the centrifuge step above, add } \\
100 \mathrm{~mL} \text { of } 1 \mathrm{M} \mathrm{NaOAc} \text { solution at } \mathrm{pH} 5\end{array}$ \\
\hline & & 2. Shake for $3 \mathrm{hr}$ \\
\hline & & 3. Centrifuge at $2000 \mathrm{rpm}$ for 30 minutes \\
\hline & & 4. Filter supernatant using 0.45 -micron filter \\
\hline & & 5. Collect filtrate, label "Carbonates" \\
\hline \multirow{5}{*}{$\begin{array}{l}\text { Step 3: } \\
\text { Fe-Mn Oxides }\end{array}$} & \multirow{5}{*}{$\begin{array}{l}0.04 \mathrm{M} \mathrm{NH}{ }_{2} \mathrm{OH} \cdot \mathrm{HCl} \\
\text { in } 25 \%(\mathrm{v} / \mathrm{v}) \mathrm{HOAC}\end{array}$} & $\begin{array}{l}\text { 1. To residue from the centrifuge step above, add } \\
100 \mathrm{~mL} \text { of } 0.04 \mathrm{M} \mathrm{NH} \mathrm{H}_{2} \mathrm{OH} \cdot \mathrm{HCl} \text { in } 25 \%(\mathrm{v} / \mathrm{v}) \mathrm{HOAc}\end{array}$ \\
\hline & & $\begin{array}{l}\text { 2. Heat in water bath at } 95^{\circ} \mathrm{C} \text { for } 3 \mathrm{hr} \\
\text { with intermittent agitation }\end{array}$ \\
\hline & & 3. Centrifuge at $2000 \mathrm{rpm}$ for 30 minutes \\
\hline & & 4. Filter supernatant using 0.45 -micron filter \\
\hline & & 5. Collect filtrate, label "Fe-Mn Oxides" \\
\hline \multirow{9}{*}{$\begin{array}{l}\text { Step 4: } \\
\text { Organic Matter \& Sulfide }\end{array}$} & \multirow{4}{*}{$0.02 \mathrm{M} \mathrm{HNO}_{2}$ and $30 \% \mathrm{H}_{2} \mathrm{O}_{2}$} & $\begin{array}{l}\text { 1. To residue from the centrifuge step above, add } 30 \mathrm{~mL} \\
\text { of } 0.02 \mathrm{M} \mathrm{HNO}_{3} \text { and } 240 \mathrm{~mL} \text { of } 30 \% \mathrm{H}_{2} \mathrm{O}_{2} \text { at } \mathrm{pH} 2\end{array}$ \\
\hline & & 2. Warm in water bath at $85^{\circ} \mathrm{C}$ for $2 \mathrm{hr}$ \\
\hline & & 3. Add $30 \mathrm{~mL}$ of $30 \% \mathrm{H}_{2} \mathrm{O}_{2}$ at $\mathrm{pH} 2$ \\
\hline & & $\begin{array}{l}\text { 4. Warm in water bath at } 85^{\circ} \mathrm{C} \text { for another } 3 \mathrm{hr} \text { with } \\
\text { intermittent agitation }\end{array}$ \\
\hline & \multirow{5}{*}{$\begin{array}{l}\text { 3.2 } \mathrm{M} \mathrm{NH}_{4} \mathrm{OAc} \text { in } \\
220 \% \mathrm{HNO}_{3}\end{array}$} & 5. Cool and add $50 \mathrm{~mL}$ of $3.2 \mathrm{M} \mathrm{NH}_{4} \mathrm{Oac}$ in $20 \% \mathrm{HNO}_{3}$ \\
\hline & & 6. Dilute to $200 \mathrm{~mL}$ and shake for 30 minutes \\
\hline & & 7. Centrifuge at $2000 \mathrm{rpm}$ for 30 minutes \\
\hline & & 8. Filter supernatant using 0.45 -micron filter \\
\hline & & 9. Collect supernatant, label "OM and Sulfides" \\
\hline \multirow{5}{*}{$\begin{array}{l}\text { Step 5: } \\
\text { Residual }\end{array}$} & \multirow{5}{*}{$1 \mathrm{M} \mathrm{HNO}_{3}$ and $1 \mathrm{M} \mathrm{H}_{3} \mathrm{PO}_{4}$} & 1. Remove residue from centrifuge bottles and weigh \\
\hline & & 2. Dry residue for $24 \mathrm{hr}$ \\
\hline & & 3. Weigh dried sample and grind for 10 minutes \\
\hline & & $\begin{array}{l}\text { 4. Microwave samples using method } 3050 \mathrm{~B} \text { (method } \\
\text { modified by using } 8 \mathrm{~mL} \text { of } \mathrm{HNO}_{3} \text { and } 2 \mathrm{~mL} \text { of } \mathrm{H}_{3} \mathrm{PO}_{4} \text { to } 2 \mathrm{~g} \\
\text { of dried sample) }\end{array}$ \\
\hline & & 5. Filter samples and label "Residual” \\
\hline
\end{tabular}


The names of the fractions are attributed to the metal (i.e. lead) phases found in the environment. Because the definition is operational, the extraction system becomes more aggressive by using different extraction solutions. In this way, the relative availability of the metals can be evaluated, with metals in the exchangeable fraction considered the most bioavailable and metals in the residual fraction the least bioavailable.

\section{Soil Separation Technologies}

The removal of DU from each site soil was compared using dry sieving, wet sieving, heavy liquid density separation, and water/momentum density separation (Wilfley Table). The sieve sizes and the corresponding soil particle sizes used in the physical separation processes are listed in Table 4.

Table 4. Sieve sizes used in the comparison of physical separation processes for the Yuma Proving Ground soils

\begin{tabular}{|c|c|c|}
\hline \multirow{2}{*}{$\begin{array}{c}\text { US Mesh } \\
\text { Sieve Number }\end{array}$} & \multicolumn{2}{|c|}{ Mesh Size } \\
\cline { 2 - 3 } & Inches & Millimeters \\
\hline 4 & 0.1870 & 4.76 \\
\hline 10 & 0.0787 & 2.00 \\
\hline 20 & 0.0331 & 0.841 \\
\hline 50 & 0.0117 & 0.297 \\
\hline 60 & 0.0098 & 0.250 \\
\hline 120 & 0.0049 & 0.125 \\
\hline 400 & 0.0015 & 0.037 \\
\hline
\end{tabular}

\section{Dry sieve separation}

The sites tested by dry sieve separation were the Catch Box, Range 20, and the DU Garden. The Retention Pond soil was not separated by dry sieving because it was of a very fine texture and very homogeneous in particle size. The dry sieve operation conducted at YPG used a SWECO Vibro-Energy Round Separator with discreet screen sizes to separate 4 to $8 \mathrm{Kg}$ of soil from each of the sampling sites (Figure 6). The fractions collected and analyzed were based on the specific U.S. sieve screen sizes listed in Table 5. The sieves were stacked to divide samples into four size fractions. Each size fraction was analyzed for DU in order to establish whether DU is preferentially associated with a particular soil particle size. Following sieving, the samples were shipped to ERDC-Vicksburg, MS where they were sub- 
sampled for the second laboratory grinding, as described above, and metals extraction and analysis.
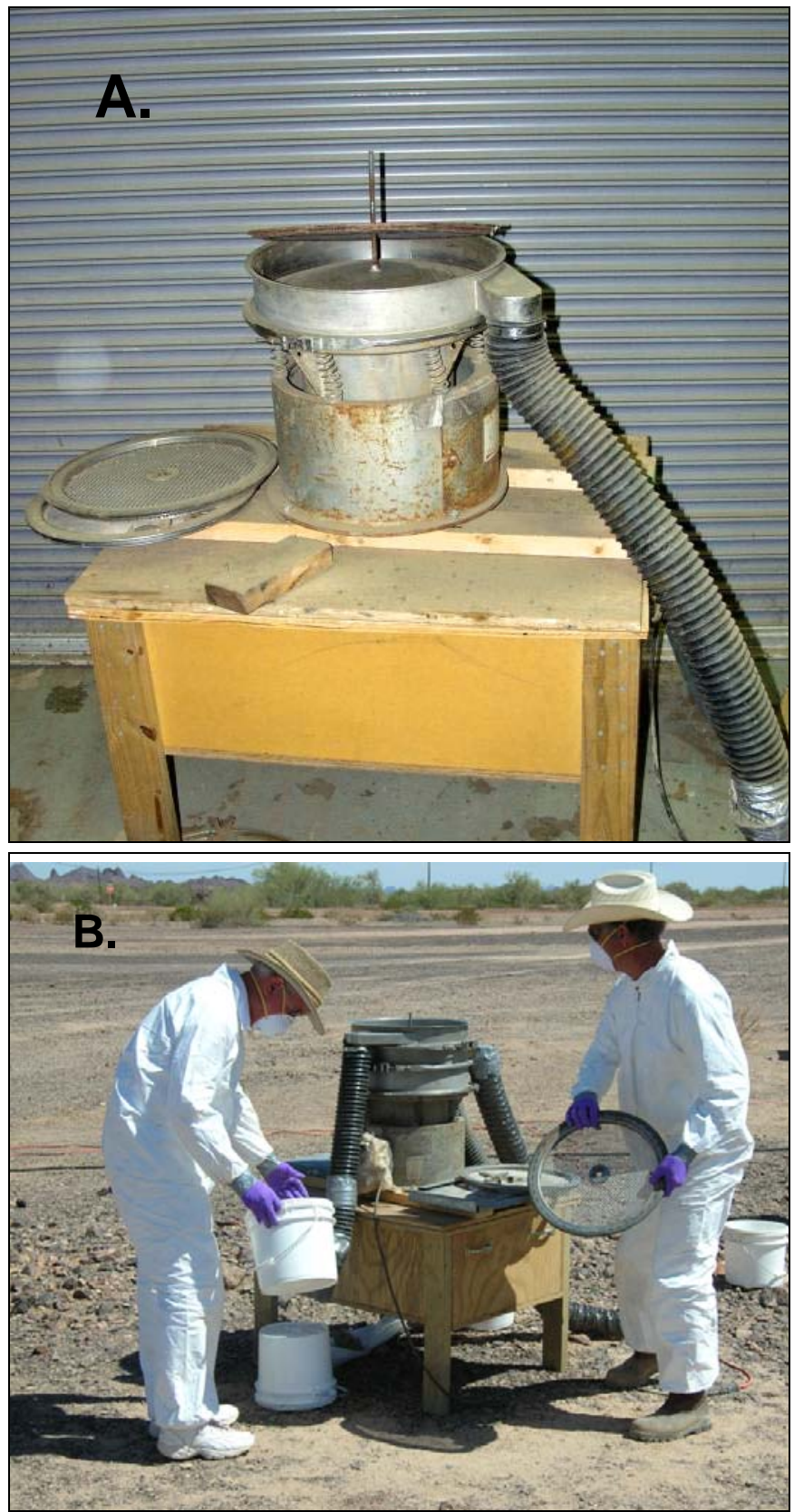

Figure 6. SWECO Vibro-Energy round soil separator used for dry sieve operations, a. In the laboratory, b. Dry sieve soil separation field operation at Yuma Proving Ground 
Table 5. Specific sieve sizes and particle sizes of fractions collected during the dry sieve process.

\begin{tabular}{|c|c|l|}
\hline US Mesh Sieve Number & \multicolumn{1}{|c|}{$\begin{array}{c}\text { Particle Size } \\
(\mathrm{mm})\end{array}$} & \multicolumn{1}{|c|}{ Fraction Collected } \\
\hline 4 & 4.76 & $>4.76 \mathrm{~mm}$ \\
\hline 10 & 2.00 & $4.76 \mathrm{~mm}$ to $2.00 \mathrm{~mm}$ \\
\hline 50 & 0.297 & $2.00 \mathrm{~mm}$ to $0.297 \mathrm{~mm}$ \\
\cline { 2 - 3 } & & $<0.297 \mathrm{~mm}$ \\
\hline
\end{tabular}

\section{Wet sieve separation}

The wet sieve separation examined soils from the Retention Pond, Range 20, and the DU Garden. The wet sieve operation conducted at YPG is illustrated in Figure 7. The sieve sizes and particle size fractions collected were the same as for the dry sieve for Range 20 and the DU Garden (Table 5) but the sample size was somewhat less $(0.50$ - $1 \mathrm{Kg})$. Because previous sieve measurements had shown the Retention Pond sediment to be fine and homogeneous in texture, finer sieve sizes (\#20, \#60, \#120, and \#400 meshes) were used for the wet separation of this sample, separating the sample into 0.841-mm to 0.037-mm particle sizes (Table 6). The wet sieving process was set up like the dry process: the sieves were stacked and the sample was placed on the top sieve. Water was run into the stacked sieves through the top using Tygon ${ }^{\circledR}$ tubing and a peristaltic pump set at $15-50 \mathrm{~mL} / \mathrm{min}$. The water works with the sieving motion to disaggregate soil lumps, rapidly separating the soil into the various size fractions. The wet process separates the fine material much more efficiently than dry sieving. A plastic funnel was placed between the sieves and bucket to eliminate spillage. The wet sieve continued until the discharge liquid was clear. Sample residues on the sieves were oven-dried overnight at $105^{\circ} \mathrm{C}$, then transferred to a desiccator and weighed. The dried samples were shipped to ERDC-Vicksburg, MS where they were sub-sampled for a second laboratory grinding, as described above, and metals extraction and analysis. 


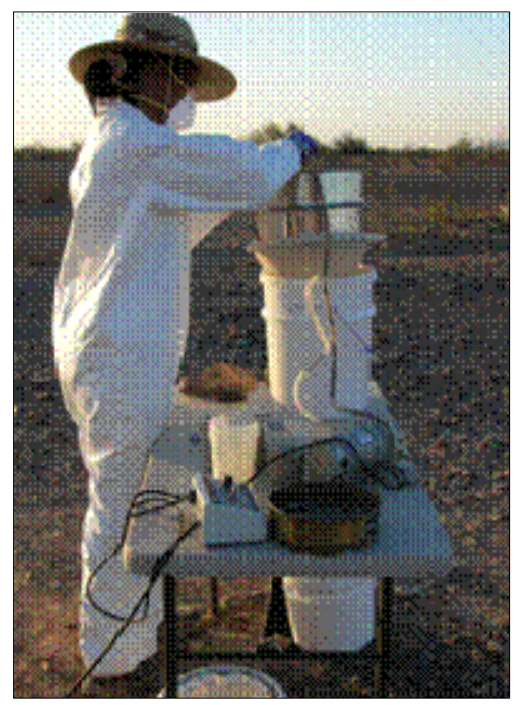

Figure 7. The wet sieve operation employed at YPG

Table 6. Specific sieve sizes and particle sizes of fractions collected during the wet sieve separation of the Retention Pond soil.

\begin{tabular}{|c|c|l|}
\hline US Mesh Sieve Number & $\begin{array}{c}\text { Particle Size } \\
(\mathrm{mm})\end{array}$ & \multicolumn{1}{|c|}{ Fraction Collected } \\
\hline 20 & 0.841 & $>0.841 \mathrm{~mm}$ \\
\hline 60 & 0.250 & $<0.841 \mathrm{~mm}$ to $>0.250 \mathrm{~mm}$ \\
\hline 120 & 0.125 & $<0.250 \mathrm{~mm}$ to $>0.125 \mathrm{~mm}$ \\
\hline 400 & 0.037 & $<0.125 \mathrm{~mm}$ to $>0.037 \mathrm{~mm}$ \\
\cline { 3 - 3 } & & $<0.037 \mathrm{~mm}$ \\
\hline
\end{tabular}

\section{Heavy liquid density separation}

Gravity separation technologies separate particles based on differential settling (related to particle size, shape, and density) through water, or another liquid medium. Each separated fraction consists of various size particles that fall into a similar range of density. These technologies can be very effective for separating organic, metallic, and geologic particles of the same or similar size that have different densities (Larson et al. 2007b). This approach was considered for the YPG site because of the high density of both the uranium metal and the uranium oxides. The specific gravity of uranium is $18.95 \mathrm{~g} / \mathrm{cm}^{3}$, while that of rock/ soil/sand varies, but can be approximated at $2.5 \mathrm{~g} / \mathrm{cm}^{3}$. In order to evaluate the separation of uranium from the four site soils studied at YPG, a series of heavy liquid density separations were performed using a polytungstate solution with a density 
of $2.85 \mathrm{~g} / \mathrm{cm}^{3}$. This liquid is dense enough to suspend most soil particles, including stones, in the solution, leaving a bottom layer of solids with densities significantly greater than that of the heavy liquid. An additional fraction is suspended in the heavy liquid and is most often considered part of the floating fraction. Because of the small sample sizes obtained from HLDS, the large field grinder would not produce useful field ground samples. Therefore all of the HLDS samples were transported to the laboratory for grinding, digestion, and analysis.

In the mining industry, the heavy fraction of a mineral suite usually contains the valuable component, which is separated from sand (silica) and other components having a density less than $2.5 \mathrm{~g} / \mathrm{cm}^{3}$. The solution density used for this type of separation is $2.85 \mathrm{~g} / \mathrm{cm}^{3}$, nearly three times the density of water. Two isopolytungstate compounds have been available for some time, and are known as sodium metatungstate or sodium polytungstate (SPT) and lithium metatungstate (LMT). The tungsten anion for SPT and LMT is $\left[\mathrm{H}_{2} \mathrm{~W}_{12} \mathrm{O}_{40}\right]^{6-}$. These compounds belong to a class of structures known in the literature as the "Keggin" species. Both SPT and LMT are relatively non-toxic and generally inert. SPT has a viscosity of over $20 \mathrm{cP}$ at a density of $2.85 \mathrm{~g} / \mathrm{mL}$. While this makes a gravity separation technique potentially very effective for the removal of uranium from soil, the expense of SPT makes it impractical for field-scale separations.

Heavy liquid density separation was used to separate soil samples from the Catch Box, the Retention Pond, Range 20, and the DU Garden. The heavy liquid used at the YPG site was a sodium polytungstate/ water solution (POLY-GEE Brand Sodium Polytungstate (liquid), density 2.9, GEOLIQUIDS, Prospect Heights, IL). A schematic of the heavy liquid density separation process is shown in Figure 8. The heavy liquid is poured slowly over the soil sample in a large container. The heavy liquid will float the less dense soil away from the dense DU metal and DU oxides. Pouring off the heavy liquid through filter paper physically separates the three fractions: the floating fraction on the surface of the heavy liquid, the suspended fraction held within the liquid, and the bottom fraction resting on the container bottom (Figure 9). The values for tungsten seen in the data tables in Appendix D, "Heavy Liquid Density Separation," are due to the tungsten heavy liquid used in the separation. 


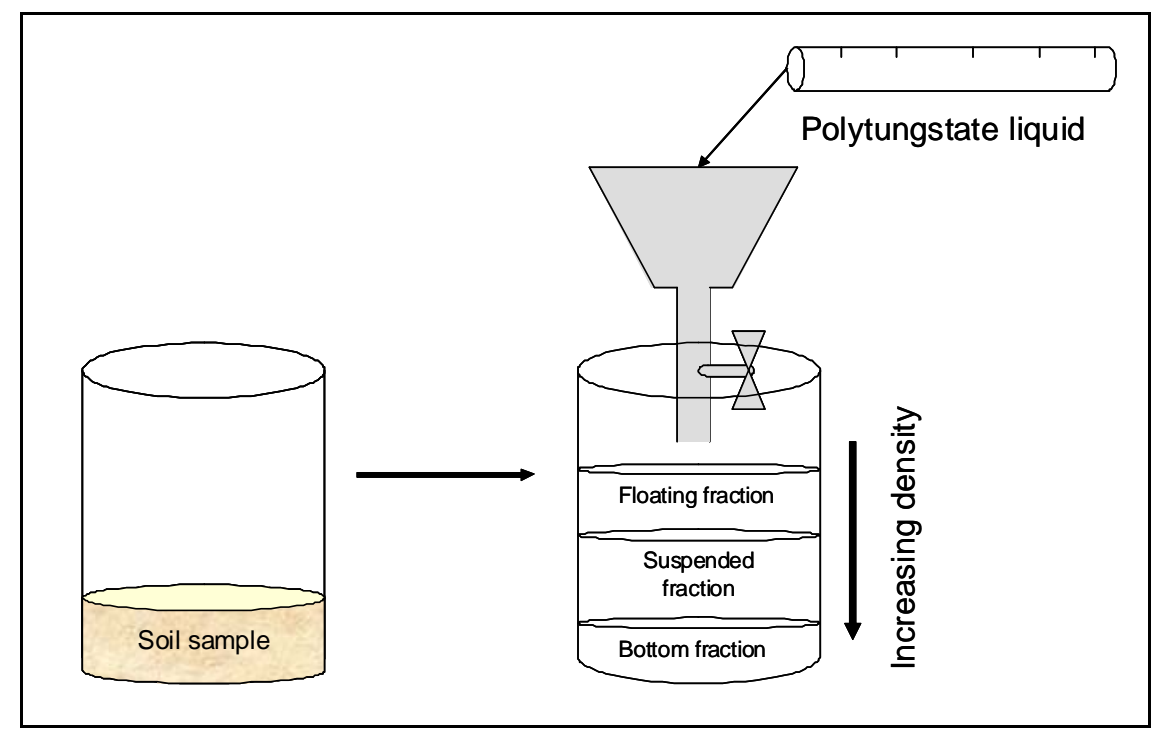

Figure 8. Schematic of the heavy liquid density separation process.

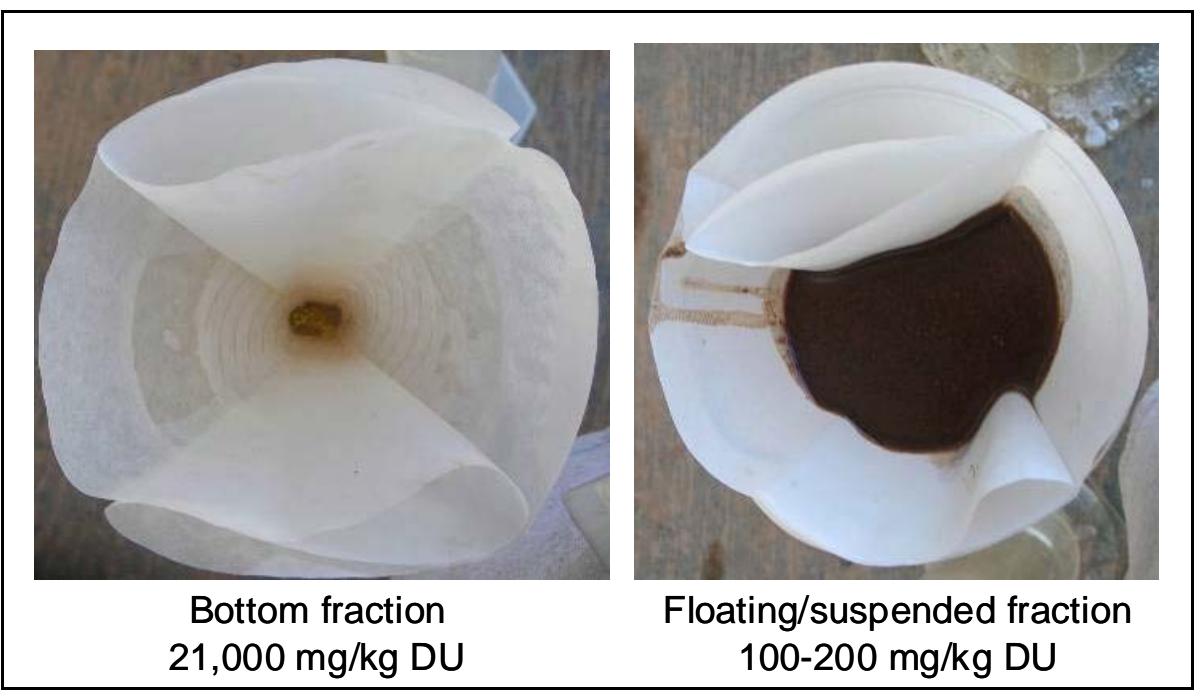

Figure 9 . The soil fractions produced by filtration of the heavy liquid solution.

\section{Water/momentum density separation}

Water/momentum density separation was used to process the YPG soils from the Catch Box, Range 20, and the DU Garden. The Wilfley Table separation processed two different sieve sizes of soil from each site, the 0.841-mm and 0.297-mm particle sizes.

The Wilfley table (Figures 10, 11, and 12) has a slope of $25^{\circ}$. As water flows across the surface, the table moves from side to side with a rapid backstroke and a slower forward stroke. The longitudinal grooves in the surface trap the high-density particulates moving them to the end of the table opposite the feed. The coarser, lighter particles exit near the feed end of the 
table. The previously dried, sieved soil fractions from the study sites were slurried in water and introduced to the separator. Soil (and separation water) was deposited in one of several buckets depending on the distance that it migrated along the table. Six or seven buckets were used to catch the fractions depending on the soil characteristics of the sample being separated.

Following separation, the dried samples were shipped to ERDC-Vicksburg, MS where they were sub-sampled for a second laboratory grinding, as described above, and metals extraction and analysis of all samples.

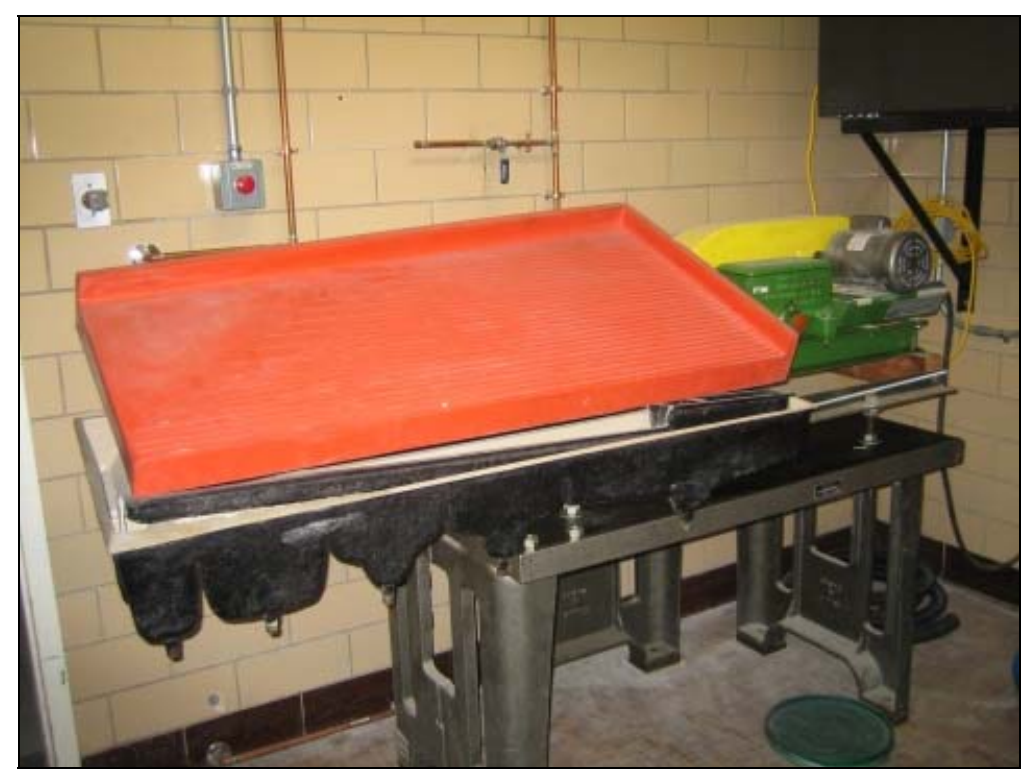

Figure 10. The Wilfley Table 


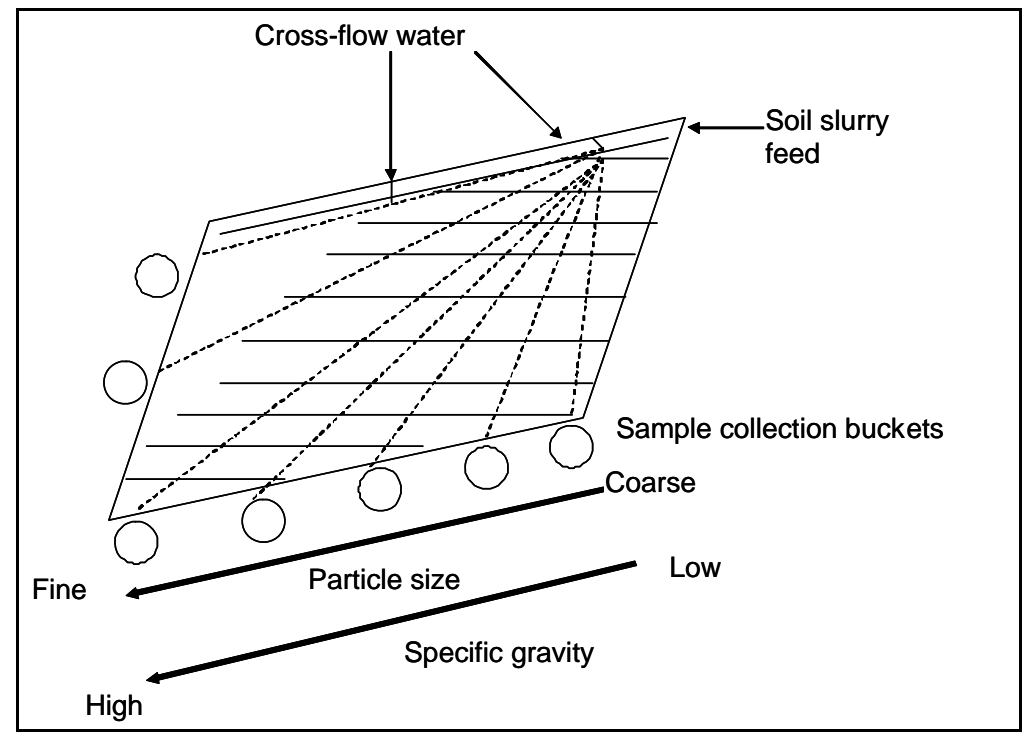

Figure 11. Schematic of a density separation table

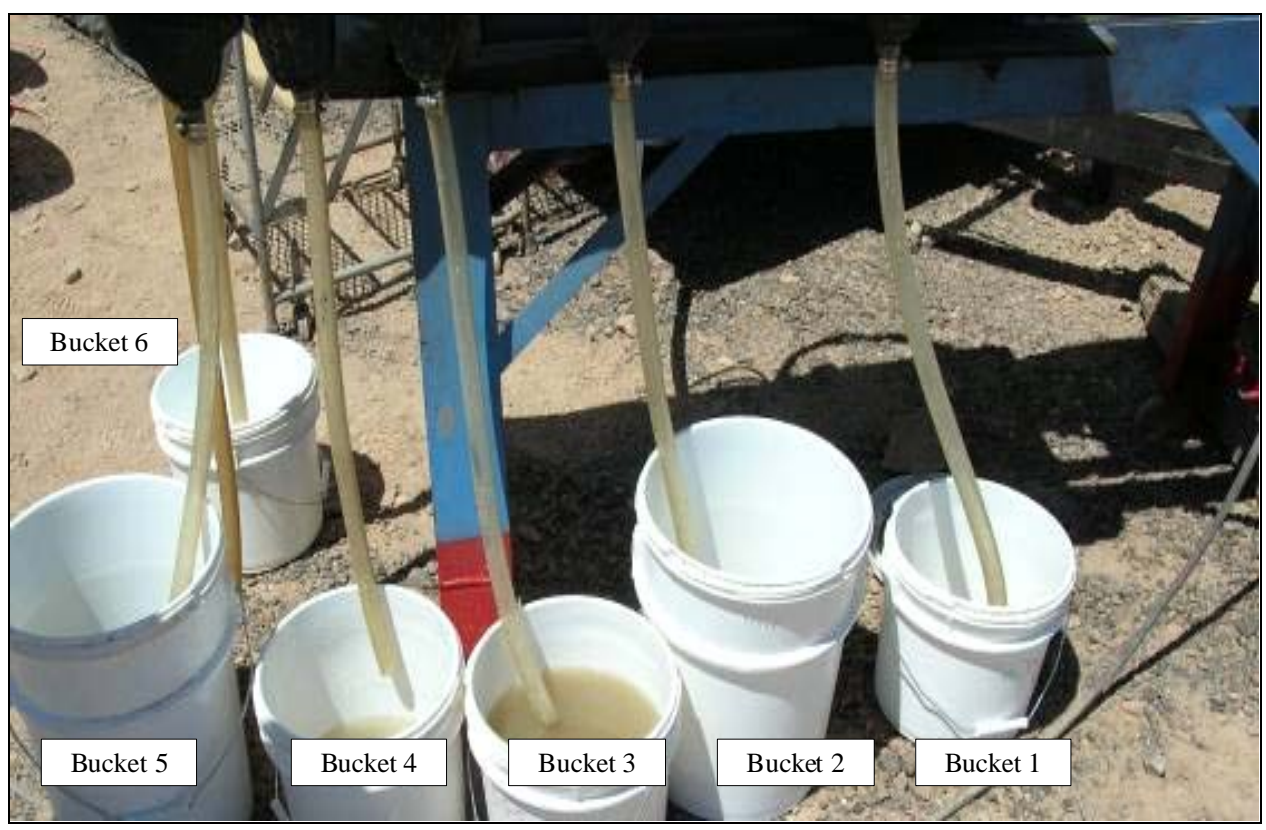

Figure 12. Field operation of the Wilfley Table showing the arrangement of the buckets collecting separation water with the various density fractions of soil. 


\section{Results}

\section{Background Samples}

Control soils obtained from areas on the YPG site believed to be uncontaminated by uranium were separated, ground, digested, and analyzed along with each of the experimental soils. Complete data on the background samples are available at the beginning of each appendix.

\section{Initial Soil Separation and Grinding}

The concentration of uranium in each of the four soil systems that were collected as composites, homogenized in the field and sub-sampled, was determined, as well as the uranium concentration in the background samples. For each site, the entire soil sample was dry sieved using a 4.76-mm sieve in order to separate the large soil particles and any DU particulates present that did not pass the 4.76-mm sieve. The mass of the soil present as the $>4.76-\mathrm{mm}$ fraction was determined gravimetrically. These larger particles were sorted by hand using a field Geiger-Mueller counter in order to separate out the DU and obtain the relative amounts of soil and uranium in this large size fraction. Table 7 presents the relative mass of both soil and uranium in the $>4$.76-mm size fraction for all four soils. There was no uranium present in the $>4.76-\mathrm{mm}$ fraction of the background soil.

Table 7. Masses of soil and uranium in the $>4.76-\mathrm{mm}$ size fraction of soil collected from the Catch Box area, the Retention Pond, Range 20, and the DU Garden at YPG.

\begin{tabular}{|c|c|c|}
\hline Sample & $\begin{array}{c}\text { Soil Mass }>4.76 \mathrm{~mm} \\
(\mathrm{~kg})\end{array}$ & $\begin{array}{c}\text { U Mass }>4.76 \mathrm{~mm} \\
(\mathrm{~g})\end{array}$ \\
\hline Catch Box & 0.41 & 3.59 \\
\hline Retention pond & * & * \\
\hline Range 20 & 5.60 & $27.7 * *$ \\
\hline DU Garden*** & 3.55 & $1,141.00$ \\
\hline \multicolumn{3}{|c|}{$\begin{array}{l}* \text { no soil / uranium particles were detected in the }>4.76-\mathrm{mm} \text { size } \\
\text { fraction } \\
* * \text { One penetrator was retained on the sieve } \\
* * * \text { lifts } 4 \text { and } 5(22.86 \mathrm{~cm}-38.10 \mathrm{~cm} \text { bgs, } 9 \text { to } 15 \mathrm{in} . \mathrm{bgs})\end{array}$} \\
\hline
\end{tabular}


The material that passed through the $4.76-\mathrm{mm}$ sieve (i.e. was $<4.76 \mathrm{~mm}$ ) was homogenized, ground in the field and sub-sampled for digestion and metals analysis using ICP-MS. Tables 8, 10, 12, and 14 present the uranium concentration present in the Catch Box, Range 20, DU Garden and Retention Pond soils, respectively, obtained by field grinding.

Additionally, the material previously sieved and ground in the field was taken to the laboratory and a sub-sample was ground a second time using the Fritsch Pulverisette 7. These samples were then digested and the digests were analyzed using ICP-MS. Tables 9, 11, 13, and 15 present the uranium concentration in the Catch Box, Range 20, the DU Garden and Retention Pond soils obtained by the second laboratory grinding.

Additional results, including data on metals other than uranium, are included in the appendices. For the initial grind, data are available in Appendix A. Data from the background samples are available in Tables A1 through A4.

For data analysis purposes, the ICP reporting limit, $0.05 \mathrm{mg} / \mathrm{kg}$, was used in place of "non-detect."

\section{Background}

In the initial grind of the background samples (Tables A1 - A4), no U was present in the field ground samples from the four sites. Uranium was present in low concentrations in all of the laboratory ground samples.

\section{Catch Box}

Three sub-samples of the single, large Catch Box soil sample were sieved through a 4.76-mm sieve, ground in the field, and digested and analyzed in the laboratory. The uranium concentration in the $>4.76-\mathrm{mm}$ fraction was determined gravimetrically. The uranium concentration in the $<4.76-\mathrm{mm}$ fraction was determined by digestion and analysis of the three sieved samples. These data, along with the average concentration of the three subsamples, are shown in Table 8.

The replicates of each of the three samples were, generally, very consistent. The percent standard deviation ranged from 6 to 22 percent. The agreement between the three Catch Box site samples had a percent standard deviation of 21 percent. 
Additional data on Catch Box Initial Grind samples can be found in Tables A5 through A7.

Table 8. Total uranium concentration in the $<4.76-\mathrm{mm}$ size fraction of the Catch Box soils, field grind.

\begin{tabular}{|c|c|c|c|c|c|c|}
\hline \multirow[t]{2}{*}{ Sample } & \multicolumn{3}{|c|}{$\begin{array}{l}\text { U Concentration } \\
(\mathrm{mg} / \mathrm{kg})\end{array}$} & \multirow[t]{2}{*}{$\begin{array}{c}\text { Average } \\
(n=3)\end{array}$} & \multirow[t]{2}{*}{ Stdev } & \multirow[t]{2}{*}{ \% Stdev } \\
\hline & 1 & 2 & 3 & & & \\
\hline Replicate A & 1115.00 & 1441.00 & 633.30 & & & \\
\hline Replicate B & 1260.00 & 1191.00 & 786.20 & & & \\
\hline Replicate C & 1228.00 & 1268.00 & 935.10 & & & \\
\hline $\begin{array}{l}\text { Average } \\
(n=3)\end{array}$ & 1201.00 & 1300.00 & 784.87 & 1095.29 & 273.35 & $24.96 \%$ \\
\hline Stdev & 76.18 & 128.04 & 150.90 & & & \\
\hline$\%$ Stdev & 6.34 & 9.85 & 19.23 & & & \\
\hline
\end{tabular}

Three sub-samples of the single, large Catch Box soil sample that were sieved through a 4.76-mm sieve and ground in the field, were further ground in the laboratory using the Fritsch Pulverisette 7, then digested and analyzed. The uranium concentrations determined by digestion and analysis of the three sieved samples along with the average concentration of the three sub-samples are shown in Table 9. Compared to the single field grinding, the uranium concentrations following the laboratory grinding were slightly lower. However, the percent standard deviation was also decreased, ranging from 0.5 to 8.9 percent, indicating a more homogeneous sample. Overall, the percent standard deviation between the three sub-samples was 18 percent, only a slight decrease from the 21 percent obtained from the single grinding.

\section{Retention Pond}

The Retention Pond collects surface water runoff diverted from the Catch Box. A single sample of the dried sediment present in the pond area was homogenized, ground in the field, and digested and analyzed in the laboratory. This sample contained no soil particles or penetrator particles $>4.76 \mathrm{~mm}$ (see Table 6). The uranium concentrations determined by digestion and analysis of the three field-ground samples are shown in Table 10. Additional data on the results of the analysis of the Initial Grind samples from the Retention Pond soil are presented in Table A8. 
Table 9. Total uranium concentration in the $<4.76-\mathrm{mm}$ size fraction of the Catch Box soils, laboratory grind.

\begin{tabular}{|c|c|c|c|c|c|c|}
\hline \multirow[t]{2}{*}{ Sample } & \multicolumn{3}{|c|}{$\begin{array}{l}\text { U Concentration } \\
(\mathrm{mg} / \mathrm{kg})\end{array}$} & \multirow[t]{2}{*}{$\begin{array}{c}\text { Average } \\
(n=3)\end{array}$} & \multirow[t]{2}{*}{ Stdev } & \multirow[t]{2}{*}{$\begin{array}{c}\% \\
\text { Stdev }\end{array}$} \\
\hline & 1 & 2 & 3 & & & \\
\hline Replicate A & 988.20 & $1,060.00$ & 751.50 & & & \\
\hline Replicate B & 940.30 & $1,068.00$ & 700.90 & & & \\
\hline Replicate C & $1,115.00$ & $1,071.00$ & 775.60 & & & \\
\hline $\begin{array}{l}\text { Average } \\
(n=3)\end{array}$ & $1,014.50$ & $1,066.33$ & 742.67 & 941.17 & 173.85 & 18.47 \\
\hline Stdev & 90.27 & 5.69 & 38.13 & & & \\
\hline \% Stdev & 8.90 & 0.53 & 5.13 & & & \\
\hline
\end{tabular}

Table 10. Total uranium concentration in the $<4.76-\mathrm{mm}$ size fraction taken from the Retention Pond, field ground.

\begin{tabular}{|l|c|c|c|c|}
\hline Replicate & $\begin{array}{c}\text { U } \\
\text { Concentration } \\
(\mathrm{mg} / \mathrm{kg})\end{array}$ & $\begin{array}{c}\text { Avg } \\
(\mathrm{n}=3)\end{array}$ & Stdev & \% Stdev \\
\cline { 1 - 2 } A & 910.10 & 904.83 & 9.21 & 1.02 \\
\cline { 1 - 2 } & 894.20 & & & \\
\hline C & 910.20 & & & \\
\hline
\end{tabular}

A single sample of the dried sediment present in the Retention Pond was further ground using the Fritsch Pulverisette 7 and digested and analyzed in the laboratory. The uranium concentrations determined by digestion and analysis of the three sieved samples are shown in Table 11. Compared to the single field grinding, the uranium concentrations following the second laboratory grinding were slightly higher, with an identical 1-percent standard deviation.

Table 11. Total uranium concentration in the $<4.76-\mathrm{mm}$ size fraction of the sample taken from the Retention Pond, laboratory ground.

\begin{tabular}{|l|c|c|c|c|}
\hline Replicate & $\begin{array}{c}\text { U } \\
\text { Concentration } \\
(\mathrm{mg} / \mathrm{kg})\end{array}$ & $\begin{array}{c}\text { Avg } \\
(\mathrm{n}=3)\end{array}$ & Stdev & \% Stdev \\
\cline { 1 - 2 } A & $1,151.00$ & $1,160.67$ & 13.43 & 1.16 \\
\cline { 1 - 2 } B & $1,155.00$ & & & \\
\hline
\end{tabular}


Range 20

Following screening with the Geiger-Mueller counter, the $>4.76-\mathrm{mm}$ fraction was separated into DU and non-DU-containing fractions. The uranium concentration of the $>4.76$ - $\mathrm{mm}$ fraction was determined gravimetrically. Table 12 presents the uranium concentrations of the triplicate digestion and analysis of the three $<4$.76-mm sieved samples of the Range 20 soil following field grinding. Table 13 presents the uranium concentrations of the digestion and analysis of the three sieved samples along with the average concentration of the three sub-samples from the $<4.76-\mathrm{mm}$ size fraction of the three samples from Range 20 that received a second laboratory grinding. The average concentrations and percent standard deviations of the replicates were similar between the single and double grindings. However, the percent standard deviation between the subsamples increased with the laboratory grinding from 19 to 28 percent. Additional data on the results of analysis of the Initial Grind of the Range 20 soils are presented in Tables A9 through A12.

Table 12. Total uranium concentration in the $<4.76-\mathrm{mm}$ size fraction of the Range 20 soils, field ground.

\begin{tabular}{|c|c|c|c|c|c|c|}
\hline \multirow[t]{2}{*}{ Sample } & \multicolumn{3}{|c|}{$\begin{array}{l}\text { U Concentration } \\
(\mathrm{mg} / \mathrm{kg})\end{array}$} & \multirow[t]{2}{*}{$\begin{array}{c}\text { Average } \\
(n=3)\end{array}$} & \multirow[t]{2}{*}{ Stdev } & \multirow[t]{2}{*}{ \% Stdel } \\
\hline & 1 & 2 & 3 & & & \\
\hline Replicate A & $8,928.00$ & $12,780.00$ & $13,330.00$ & & & \\
\hline Replicate B & $10,166.00$ & $12,960.00$ & $13,330.00$ & & & \\
\hline Replicate C & $8,866.00$ & $13,340.00$ & $13,650.00$ & & & \\
\hline $\begin{array}{l}\text { Average } \\
(n=3)\end{array}$ & $9,320.00$ & $13,026.67$ & $13,436.67$ & $11,927.78$ & $2,267.69$ & 19.01 \\
\hline Stdev & 733.31 & 285.89 & 184.75 & & & \\
\hline$\%$ stdev & 7.87 & 2.19 & 1.37 & & & \\
\hline
\end{tabular}

\section{DU Garden}

An excavation of one of the penetrators that was buried at a depth of $30.48 \mathrm{~cm}$ (12 in.) in the DU Garden at YPG produced five soil lifts. Each lift contained the entire mass of soil excavated within a 7.62-cm (3-in.) depth. The depth and mass of each lift are recorded in Table 14. 
Table 13. Total uranium concentration in the $<4.76-\mathrm{mm}$ size fraction of the Range 20 soils, laboratory ground.

\begin{tabular}{|c|c|c|c|c|c|c|}
\hline \multirow[t]{2}{*}{ Sample } & \multicolumn{3}{|c|}{$\begin{array}{l}\text { U Concentration } \\
(\mathrm{mg} / \mathrm{kg})\end{array}$} & \multirow[t]{2}{*}{$\begin{array}{l}\text { Average } \\
(n=3)\end{array}$} & \multirow[t]{2}{*}{ Stdev } & \multirow[t]{2}{*}{ \% Stdev } \\
\hline & 1 & 2 & 3 & & & \\
\hline Replicate A & $6,635.00$ & $13,080.00$ & $12,850.00$ & & & \\
\hline Replicate B & $7,649.00$ & $13,120.00$ & $12,950.00$ & & & \\
\hline Replicate C & $7,620.00$ & $13,120.00$ & $12,550.00$ & & & \\
\hline $\begin{array}{l}\text { Average } \\
(n=3)\end{array}$ & $7,301.33$ & $13,106.67$ & $12,783.33$ & $11,063.78$ & $3,262.38$ & 29.49 \\
\hline Stdev & 577.24 & 23.09 & 208.17 & & & \\
\hline$\%$ stdev & 7.91 & 0.18 & 1.63 & & & \\
\hline
\end{tabular}

Table 14. Depth (bgs) and soil mass associated with the excavation of a buried penetrator rod from the DU Garden.

\begin{tabular}{|c|c|c|c|}
\hline \multirow[t]{2}{*}{ Lift Number } & \multicolumn{2}{|c|}{$\begin{array}{c}\text { Depth } \\
\text { (bgs) }\end{array}$} & \multirow[t]{2}{*}{$\begin{array}{c}\text { Soil Mass } \\
\text { (Kg) }\end{array}$} \\
\hline & $\mathrm{cm}$ & in & \\
\hline 1 & $0-7.62$ & $0-3$ & 112.58 \\
\hline 2 & $7.62-15.24$ & $3-6$ & 94.60 \\
\hline 3 & $15.24-22.86$ & $6-9$ & 78.18 \\
\hline 4 & $22.86-30.48$ & $9-12$ & 63.33 \\
\hline 5 & $30.48-38.10$ & $12-15$ & 50.04 \\
\hline
\end{tabular}

Following screening with the Geiger-Mueller counter, the $>4.76-\mathrm{mm}$ fraction was separated into DU and non-DU-containing fractions. The uranium concentration of the $>4$.76-mm fraction was determined gravimetrically. Each of the size fractions $<4.76 \mathrm{~mm}$ was ground in the field and digested and analyzed in the laboratory. Table 15 presents the uranium concentrations of the digestion and analysis of this sieved sample along with the average concentration of the three digestion/ analysis replicates for each of the five depth samples. Unlike the Catch Box and Range 20 sites, a single sample was obtained from each of the five depths. This sample was digested and analyzed in triplicate. There was no triplicate analysis of separate samples. Additional data on the results of the Initial Grind of the Catch Box soils can be found in Tables A13 through A17. 
Table 15. Total uranium concentrations in the $<4.76-\mathrm{mm}$ size fraction of the five depth range samples obtained during the excavation of a penetrator rod buried at $30.48 \mathrm{~cm} \mathrm{(12} \mathrm{in.} \mathrm{bgs)} \mathrm{in}$ the DU Garden, field ground.

\begin{tabular}{|l|c|c|c|c|c|}
\hline \multirow{2}{*}{ Replicate } & \multicolumn{5}{|c|}{ U Concentration per Lift (mg/kg) } \\
\cline { 2 - 6 } & $\begin{array}{c}1 \\
0-7.62 \\
\mathrm{~cm}\end{array}$ & $\begin{array}{c}2 \\
7.62-15.24 \\
\mathrm{~cm}\end{array}$ & $\begin{array}{c}3 \\
15.24- \\
22.86 \mathrm{~cm}\end{array}$ & $\begin{array}{c}22.86-30.48 \\
\mathrm{~cm}\end{array}$ & $\begin{array}{c}30.48-38.10 \\
\mathrm{~cm}\end{array}$ \\
\hline A & $<0.05^{*}$ & $<0.05$ & $<0.05$ & $22,160.00$ & $36,290.00$ \\
\hline B & $<0.05$ & $<0.05$ & $<0.05$ & $20,670.00$ & $34,870.00$ \\
\hline C & $<0.05$ & $<0.05$ & $<0.05$ & $21,700.00$ & $35,890.00$ \\
\hline $\begin{array}{l}\text { Average } \\
(\mathrm{n}=3)\end{array}$ & na & na & na & $21,510.00$ & $35,683.33$ \\
\hline Stdev & & & & 762.95 & 732.21 \\
\hline \% Stdev & & & & 3.55 & 2.05 \\
\hline $\begin{array}{l}\text { *The laboratory reporting limit was used for calculations when the value was non-detect. } \\
\text { na - not applicable }\end{array}$
\end{tabular}

Each of these soil samples was further ground in the laboratory using the Fritsch Pulverisette 7, and digested and analyzed. Table 16 presents the uranium concentrations produced by the digestion and analysis of this laboratory ground sample along with the average concentration of the three digestion/ analysis replicates for each of the five depth samples.

Table 16. Total uranium concentrations in the $<4.76-\mathrm{mm}$ size fraction of the five depth range samples obtained during the excavation of a penetrator rod buried at $30.48 \mathrm{~cm}$ (12 in. bgs) in the DU Garden, laboratory ground.

\begin{tabular}{|c|c|c|c|c|c|}
\hline \multirow{2}{*}{ Replicate } & \multicolumn{5}{|c|}{ U Concentration per Lift (mg/kg) } \\
\cline { 2 - 6 } & $\begin{array}{c}1 \\
0-7.62 \\
\mathrm{~cm}\end{array}$ & $\begin{array}{c}2 \\
7.62-15.24 \\
\mathrm{~cm}\end{array}$ & $\begin{array}{c}15.24-22.86 \\
\mathrm{~cm}\end{array}$ & $\begin{array}{c}22.86-30.48 \\
\mathrm{~cm}\end{array}$ & $\begin{array}{c}30.48-38.10 \\
\mathrm{~cm}\end{array}$ \\
\hline A & $<0.05^{*}$ & $<0.05$ & $<0.05$ & $19,860.00$ & $33,030.00$ \\
\hline B & $<0.05$ & $<0.05$ & $<0.05$ & $20,150.00$ & $33,740.00$ \\
\hline C & $<0.05$ & $<0.05$ & $<0.05$ & $20,220.00$ & $33,100.00$ \\
\hline $\begin{array}{l}\text { Average } \\
(\mathrm{n}=3)\end{array}$ & na & na & na & $20,076.67$ & $33,290.00$ \\
\hline Stdev & & & & 190.88 & 391.28 \\
\hline \% Stdev & \multicolumn{7}{|l|}{0.95} & 1.18 \\
\hline $\begin{array}{l}\text { *The laboratory reporting limit was used for calculations when the value was non-detect. } \\
\text { na - not applicable }\end{array}$
\end{tabular}




\section{Separation Technologies}

\section{Dry sieve separation}

The Catch Box, Range 20, and DU Garden samples were dry sieved using three sieve sizes. Appearances of the four size fractions of soil obtained by dry sieving are shown in Figure 13. The distribution of the uranium was then determined in these four particle size ranges. These were: $>4.76 \mathrm{~mm}$, between 4.76 and $2.00 \mathrm{~mm}$, between $2.00 \mathrm{~mm}$ and $0.297 \mathrm{~mm}$, and $<0.297 \mathrm{~mm}$. Following the initial separation, the $>4$.76- $\mathrm{mm}$ fraction was screened using a Geiger-Mueller counter and separated into DU and nonDU-containing fractions. The mass of the DU fraction was determined gravimetrically.

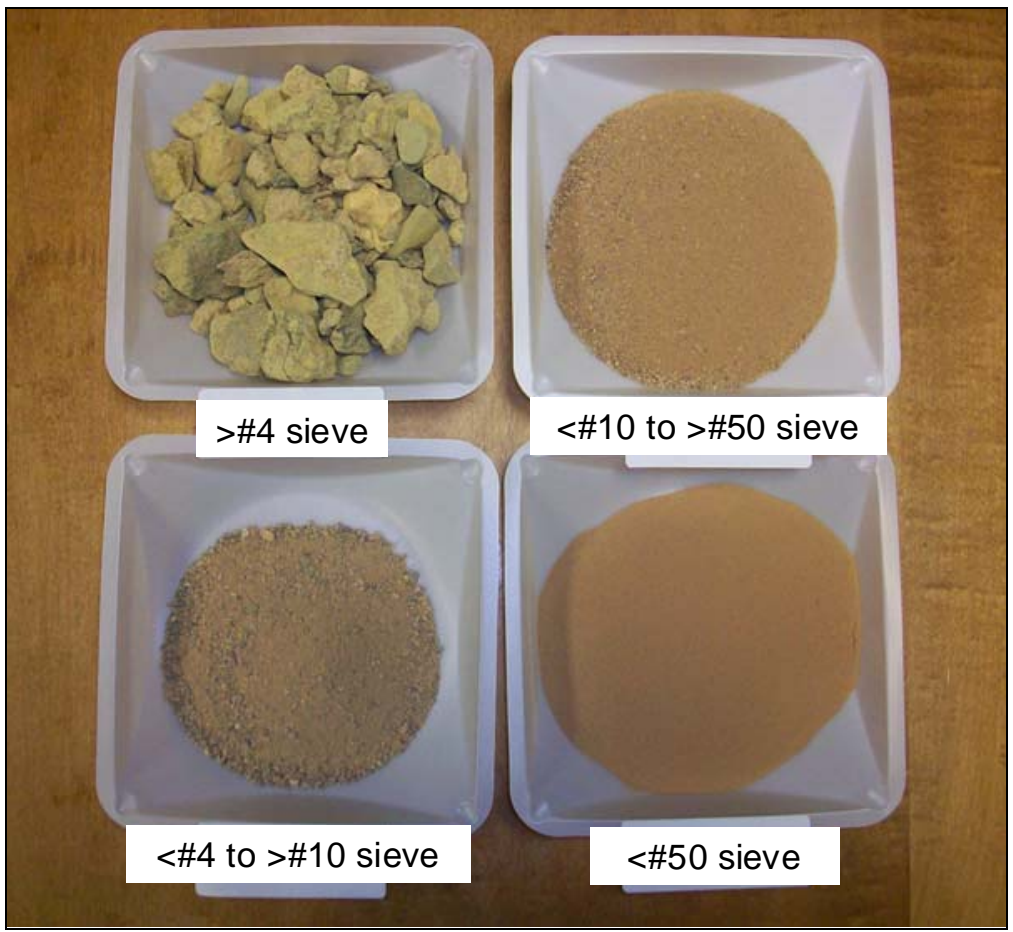

Figure 13. An example of the appearance of the size fractions obtained through dry sieving. These are the four size fractions obtained from a DU Garden soil sample.

The uranium concentration for the $>4.76$ - $\mathrm{mm}$ size fraction was obtained gravimetrically. The soil that fell in the size ranges 4.76 to $2.00 \mathrm{~mm}$ and 2.00 to $0.297 \mathrm{~mm}$ was sub-sampled, ground in the field, sub-sampled after grinding, and digested and analyzed using ICP-MS. The finest fraction, $<0.297 \mathrm{~mm}$, was sub-sampled, digested, and then analyzed using ICP-MS.

The dried sediment sample from the Retention Pond was not separated using the dry sieve apparatus. This sample contained very little material 
that was $>0.297 \mathrm{~mm}$ in size if the soil particle aggregates were allowed sufficient time to break up during the dry sieving process. A significant number of aggregate particles were easily disaggregated by hand in this sample, so dry sieving of this material was not performed.

Tables 17 through 22 present the relative mass of both soil and uranium in the greater four size ranges obtained through dry sieving of the Catch Box, Range 20, and DU Garden soil samples. Further data on the results of dry sieving these soils can be found in Appendix B.

\section{Background}

No uranium was detected in any of the replicates of size fractions produced by dry sieve separation of the background soil samples. Additional data from analysis of the background soil fractions can be found in Tables B1 through B4.

\section{Catch Box}

Table 17 presents the uranium concentrations of the triplicate digestion and analysis of the size-separated Catch Box soil along with the percent uranium in each fraction, by mass. The largest concentration of uranium (33 percent), by mass, was observed in the $<4$.76- $\mathrm{mm}$ to $>2.00$ - $\mathrm{mm}$ size fraction. An average of 15 percent of the total uranium, by mass, was detected in the $>4.76-\mathrm{mm}$ size fraction of the soil. Additional data on the results of analysis of the Catch Box soils separated by dry sieving can be found in Tables B5 through B8.

\section{Range 20}

Table 18 presents the uranium concentrations of the triplicate digestion and analysis of the size-separated Range 20 soil along with the percent $U$ in each fraction, by mass. The highest percentage of $U$ in the Range 20 soils (38 percent) was found in the $<2.00-\mathrm{mm}$ to $>0.30-\mathrm{mm}$ size fraction. The remainder of the mass of uranium from Range 20 was dispersed throughout the other three size fractions at 17, 23, and 21 percent in the $>4.76-\mathrm{mm},<4.76-\mathrm{mm}$ to $>2.00-\mathrm{mm}$, and the $<0.30$ - $\mathrm{mm}$ fractions, respectively. 
Table 17. Concentration of uranium and percent of total uranium in each of the four field ground size fractions of the Catch Box soils obtained through dry sieving separation and field grinding.

\begin{tabular}{|c|c|c|c|c|c|c|c|c|}
\hline \multirow[t]{2}{*}{ Size Fraction } & \multicolumn{3}{|c|}{$\begin{array}{l}\text { U Concentration } \\
(\mathrm{mg} / \mathrm{kg})\end{array}$} & \multirow[t]{2}{*}{$\begin{array}{l}\text { U Concentration } \\
\text { Avg, } n=3\end{array}$} & \multirow[t]{2}{*}{ Stdev } & \multirow[t]{2}{*}{$\begin{array}{c}\text { Avg Soil Mass } \\
(\mathrm{Kg})\end{array}$} & \multirow[t]{2}{*}{$\begin{array}{c}\text { Avg DU Mass } \\
\text { (mg) }\end{array}$} & \multirow[t]{2}{*}{$\begin{array}{c}\text { Avg \% Total U per } \\
\text { Size Fraction }\end{array}$} \\
\hline & CB 1 & CB 2 & CB3 & & & & & \\
\hline$>4.76 \mathrm{~mm} *$ & $12,500.00$ & $5,000.00$ & $8,678.57$ & $8,726.19$ & $3,750.23$ & 0.14 & 1196.67 & $14.84 \%$ \\
\hline$<4.76 \mathrm{~mm}$ to $>2.00 \mathrm{~mm}$ & $1,048.13$ & $1,132.33$ & $4,400.00$ & $2,206.82$ & $1,934.45$ & 1.67 & 4055.84 & $33.34 \%$ \\
\hline$<2.00 \mathrm{~mm}$ to $>0.30 \mathrm{~mm}$ & 864.70 & 853.27 & $3,424.43$ & $1,714.13$ & $1,481.17$ & 2.05 & 3385.61 & $31.02 \%$ \\
\hline$<0.30 \mathrm{~mm}$ & $1,685.67$ & $2,260.00$ & $1,911.30$ & $1,952.32$ & 289.35 & 0.87 & 1700.90 & $20.80 \%$ \\
\hline Total & $16,098.50$ & $9,245.60$ & $18,454.30$ & $14,599.47$ & $4,783.87$ & & & \\
\hline
\end{tabular}


Table 18. Concentration of uranium and the percent of the total uranium in each of the four field ground size fractions of the Range 20 soils obtained through dry sieving separation and field grinding.

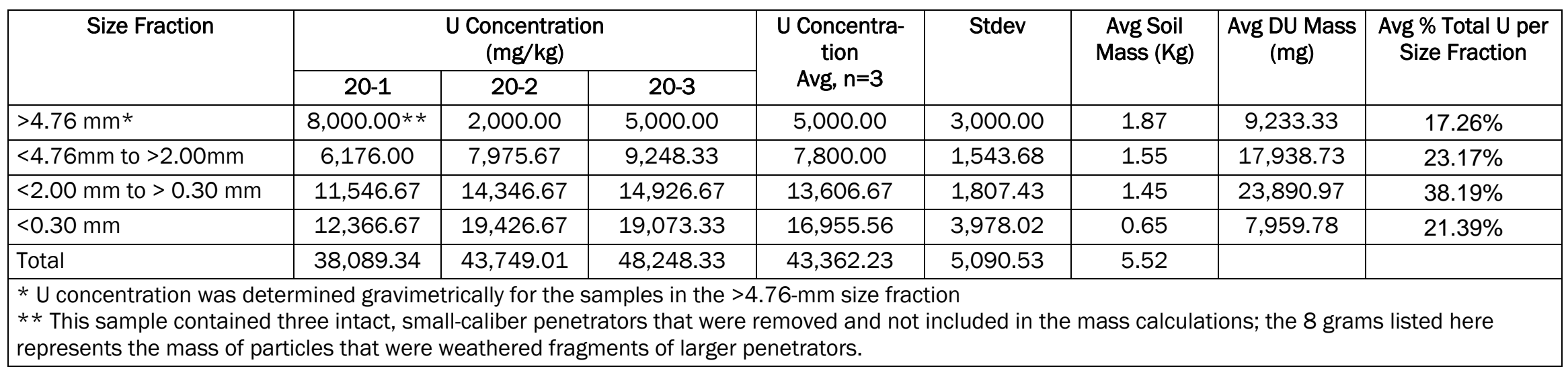


Additional data from the analysis of the fractions produced by the dry sieve separation of the Range 20 soils are presented in Tables B14 through B17.

\section{DU Garden}

One DU penetrator rod was excavated from the DU Garden. Each DU Garden sample contained the entire mass of soil excavated within a lift. Each of these soil samples was sieved through the three sieve sizes and was analyzed in triplicate. Table 19 presents the uranium concentrations of the triplicate digestion and analysis of the size-separated DU Garden soil along with the percent uranium in each fraction, by mass, for each of the five depth samples. No uranium was detected until the 22.86- $\mathrm{cm}$ (12-in.) bgs lift was reached and uranium was most concentrated at a depth of $38.10 \mathrm{~cm}$ (15 in.). At both depths, $>70$ percent of the uranium, by mass, was in the largest soil size fraction. The least amount of uranium at both depths was in the smallest soil size fraction.

Additional data from the analysis of soil size fractions obtained by dry sieve of the DU Garden soil are available in Tables B9 through B13.

\section{Wet sieve separation}

Figure 14 shows the general appearance of soil fractions obtained through wet sieving of the Catch Box, Range 20, and DU Garden soils. Because the Retention Pond sediment had a homogeneous texture and much smaller particle size distribution than the other site soils, a different set of sieves was used for the Retention Pond samples, as discussed in the section titled Materials and Methods. Tables 20, 21, 22, and 23 provide details on the concentration of uranium obtained by wet sieving soil samples from the Catch Box, the Retention Pond, Range 20, and the DU Garden, respectively. Additional data obtained from wet sieving these soils are available in Appendix C. 
Table 19. DU Garden excavation of a 12-in. penetrator rod and the soil concentration and percent mass of uranium in 7.62-cm (3-in.) increments of field ground fractions obtained by dry sieve separation and field grinding.

\begin{tabular}{|c|c|c|c|c|c|c|c|c|c|c|c|}
\hline \multirow[t]{2}{*}{$\begin{array}{l}\text { Size Frac- } \\
\text { tion }\end{array}$} & \multicolumn{5}{|c|}{$\begin{array}{c}\text { U Concentration } \\
(\mathrm{mg} / \mathrm{kg}) \\
\text { (in } 7.62 \mathrm{~cm}(3-\text { inch) increments bgs) }\end{array}$} & \multicolumn{2}{|c|}{$\begin{array}{l}\text { Soil Mass per Frac- } \\
\text { tion }\end{array}$} & \multicolumn{2}{|c|}{ Mg of $U$ per Fraction } & \multicolumn{2}{|c|}{$\begin{array}{l}\text { \% Total U per Size } \\
\text { Fraction at Depth }\end{array}$} \\
\hline & $\begin{array}{c}1 \\
0-7.62 \\
\mathrm{~cm}\end{array}$ & $\begin{array}{c}2 \\
7.62- \\
15.24 \\
\mathrm{~cm}\end{array}$ & $\begin{array}{c}3 \\
15.24- \\
22.86 \\
\mathrm{~cm}\end{array}$ & $\begin{array}{c}4 \\
22.86-30.48 \\
\mathrm{~cm}\end{array}$ & $\begin{array}{c}5 \\
30.48-38.10 \\
\mathrm{~cm}\end{array}$ & \begin{tabular}{|c|}
4 \\
$22.86-$ \\
$30.48 \mathrm{~cm}$
\end{tabular} & $\begin{array}{c}5 \\
30.48- \\
38.10 \\
\mathrm{~cm}\end{array}$ & $\begin{array}{c}4 \\
22.86-30.48 \\
\mathrm{~cm}\end{array}$ & $\begin{array}{c}5 \\
30.48-38.10 \\
\mathrm{~cm}\end{array}$ & $\begin{array}{c}4 \\
22.86- \\
30.48 \\
\mathrm{~cm}\end{array}$ & $\begin{array}{c}5 \\
30.48- \\
38.10 \\
\mathrm{~cm}\end{array}$ \\
\hline$>4.76 \mathrm{~mm} *$ & $<0.50 * *$ & $<0.50$ & $<0.50$ & $239,000.00$ & $406,000.00$ & 1.80 & 1.75 & $430,200.00$ & $710,500.00$ & $72.78 \%$ & $75.02 \%$ \\
\hline $\begin{array}{c}<4.76 \mathrm{~mm} \\
\text { to } \\
>2.00 \mathrm{~mm}\end{array}$ & $<0.50$ & $<0.50$ & $<0.50$ & $33,586.67$ & $44,000.00$ & 1.40 & 1.75 & $47,021.34$ & $77,000.00$ & $7.95 \%$ & $8.13 \%$ \\
\hline $\begin{array}{c}<2.00 \mathrm{~mm} \\
\text { to }>0.30 \\
\mathrm{~mm}\end{array}$ & $<0.50$ & $<0.50$ & $<0.50$ & $29,640.00$ & $42,756.67$ & 3.15 & 3.30 & $93,366.00$ & $141,097.01$ & $15.79 \%$ & $14.90 \%$ \\
\hline$<0.30 \mathrm{~mm}$ & $<0.50$ & $<0.50$ & $<0.50$ & $13,256.67$ & $16,820.00$ & 1.55 & 1.10 & $20,547.84$ & $18,502.00$ & $3.48 \%$ & $1.95 \%$ \\
\hline Total & & & & $315,483.34$ & $509,576.67$ & 7.90 & 7.90 & $591,135.18$ & $947,099.01$ & & \\
\hline
\end{tabular}




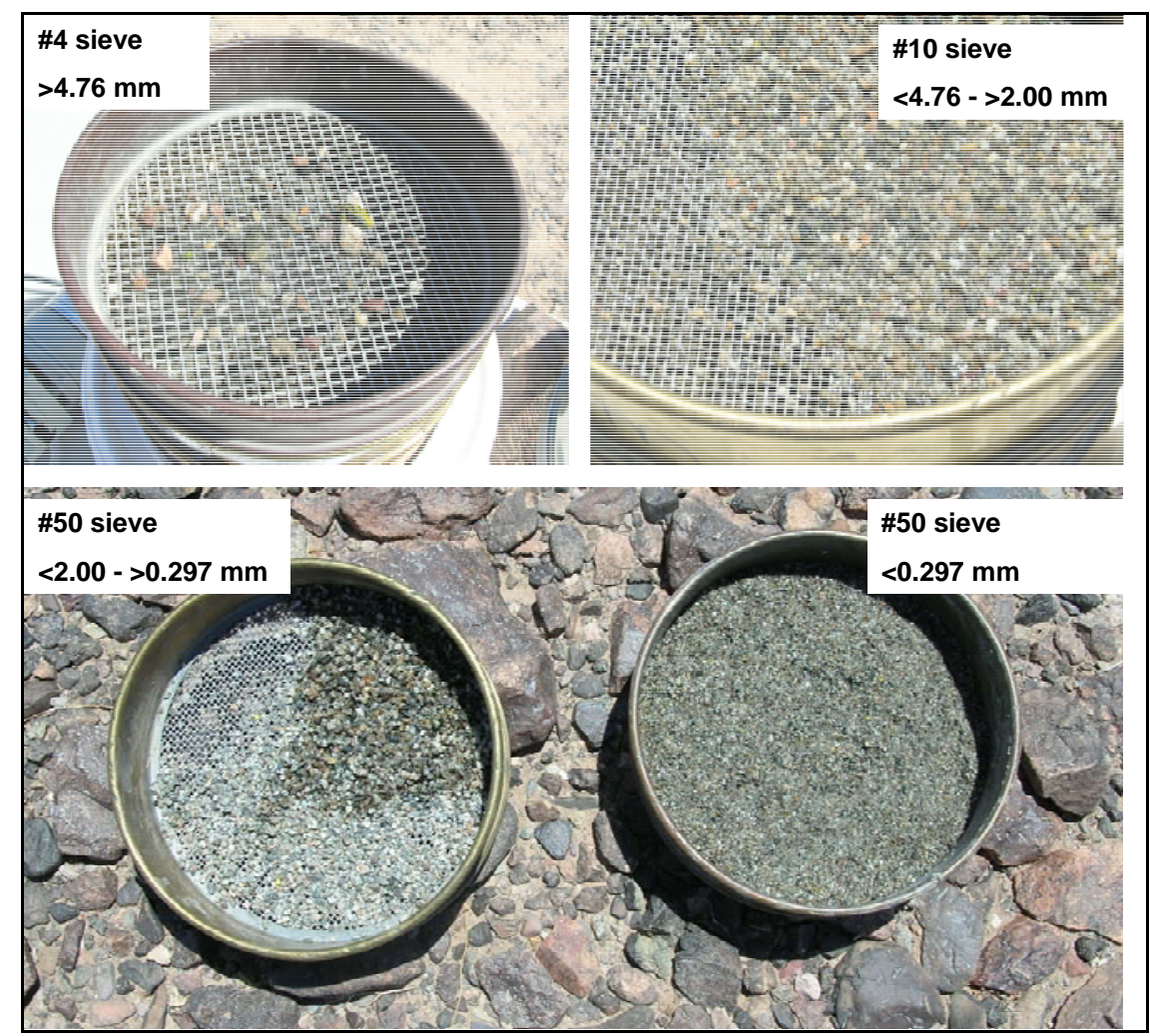

Figure 14. An example of the appearance of soil fractions obtained through wet sieving of Range 20 and DU Garden soil samples. Sieve number and soil particle sizes are indicated above the pans.

\section{Background}

No uranium was detected in any of the replicates of size fractions produced by wet sieve separation of the background soil samples. Additional data from analysis of the background soil fractions can be found in Tables $\mathrm{C} 1$ through $\mathrm{C} 4$.

\section{Catch Box}

Table 20 presents the uranium concentrations of the triplicate digestion and analysis of the size-separated Catch Box soil along with the percent uranium in each fraction, field ground, by mass. The standard deviation obtained for the concentration of uranium in each size fraction was unusually large. Normally this would indicate insufficient mixing and homogenization of the soil sample; however, the dry sieve separation results did not show this tendency and the soils for both were prepared at one time. Therefore, the high standard deviations in the wet sieve separation may be: 
Table 20. Concentration and percent of the total uranium in the different size fractions of soil from wet sieve separation of Catch Box soil samples.

\begin{tabular}{|c|c|c|c|c|c|c|c|c|}
\hline \multirow[t]{2}{*}{ Size Fraction } & \multicolumn{3}{|c|}{$\begin{array}{l}\text { U Concentration } \\
(\mathrm{mg} / \mathrm{L})\end{array}$} & \multirow{2}{*}{$\begin{array}{c}U \\
\text { Concentration } \\
\text { Avg, } n=3\end{array}$} & \multirow{2}{*}{$\begin{array}{c}U \\
\text { Concentration } \\
\text { Stdev }\end{array}$} & \multirow{2}{*}{$\begin{array}{l}\text { Avg Soil } \\
\text { Mass } \\
\text { (Kg) }\end{array}$} & \multirow[t]{2}{*}{$\begin{array}{l}\text { Avg DU Mass } \\
\text { (mg) }\end{array}$} & \multirow[t]{2}{*}{$\begin{array}{l}\text { Avg \% Total U per } \\
\text { Size Fraction }\end{array}$} \\
\hline & $\mathrm{CB}-1^{*}$ & CB -2 & CB-3 & & & & & \\
\hline$<4.76 \mathrm{~mm}$ to $>2.00 \mathrm{~mm}$ & 392.11 & $0.05 * * *$ & 68.51 & 153.56 & 209.41 & 0.15 & 23.27 & $3.07 \%$ \\
\hline$<2.00 \mathrm{~mm}$ to $>0.30 \mathrm{~mm}$ & 472.45 & 1084.00 & 1491.67 & $1,016.04$ & 513.00 & 0.41 & 426.93 & $48.90 \%$ \\
\hline
\end{tabular}

*Triplicate wet sieve analyses were performed on the Catch Box 1 sample and the average value of these triplicate analyses are presented here.

$* * U$ concentration was determined gravimetrically for the samples in the $>4.76-\mathrm{mm}$ size fraction

$* * *$ One of the three triplicates from Catch Box 1 had a 2.0-g particle of DU metal, one had a 1.0-g particle of DU metal, and the third had no DU metal par-

ticles.

$* * * *$ The laboratory reporting limit is used in place of non-detect. 
- a reflection of the water disaggregation that is part of the separation process itself,

- a reflection of the sample size undergoing separation. Wet sieving used a significantly smaller sample than the dry sieving.

For total uranium (by mass), 49 percent was present in the $<2.00-\mathrm{mm}$ to $>0.30$-mm size fraction and 46 percent was present in the $<0.30-\mathrm{mm}$ soil size fraction.

Additional data from the analysis of the soil size fractions obtained through wet sieving of the Catch Box soils can be found in Tables C5 through C8.

\section{Retention Pond}

As seen in Table 21, 97 percent of the total uranium by mass, in the sediment from the Retention Pond, was found in the smallest particle size fraction, $<0.037 \mathrm{~mm}$.

Additional data from the analysis of the size fractions produced by wet sieve separation of the Retention Pond soil are available in Table C18.

Table 21. Concentration and percent of the total uranium in the different size fractions of soil from the Retention Pond determined through Wet Sieve separation.

\begin{tabular}{|l|c|c|c|c|}
\hline Soil Fraction & $\begin{array}{c}\text { U Concentration } \\
(\mathrm{mg} / \mathrm{Kg})\end{array}$ & $\begin{array}{c}\text { Soil Mass } \\
(\mathrm{Kg})\end{array}$ & $\begin{array}{c}\text { Mass of DU } \\
(\mathrm{mg})\end{array}$ & \% Total U \\
\hline$>0.841 \mathrm{~mm}$ & 64.90 & 0.009 & 0.58 & $0.11 \%$ \\
\hline $\begin{array}{l}<0.841 \mathrm{~mm} \\
\text { to }>0.25 \mathrm{~mm}\end{array}$ & 300.87 & 0.014 & 4.21 & $0.76 \%$ \\
\hline $\begin{array}{l}<0.25 \mathrm{~mm} \text { to } \\
>0.125 \mathrm{~mm}\end{array}$ & 1515.67 & 0.006 & 9.09 & $1.64 \%$ \\
\hline $\begin{array}{l}<0.125 \mathrm{~mm} \text { to } \\
>0.037 \mathrm{~mm}\end{array}$ & 77.22 & 0.016 & 1.24 & $0.22 \%$ \\
\hline$<0.037 \mathrm{~mm}$ & 1303.67 & 0.413 & 538.42 & $97.27 \%$ \\
\hline Total & 3262.33 & 0.458 & 553.54 & \\
\hline
\end{tabular}


Range 20

Table 22 presents the uranium concentrations of the triplicate digestion and analysis of the size-separated Range 20 soil along with the percent uranium in each fraction, by mass. Over 97 percent of the total uranium present in the Range 20 soil sample used for wet sieve separation was found in the two smallest size fractions. The uranium concentration in the largest size fraction was below laboratory reporting limits for each of the three large samples. For analysis, the reporting limit was used in place of "non-detect."

Additional data on the analysis of the size fractions produced by wet sieve separation of the Range 20 soil are available in Tables C14 through C17.

\section{DU Garden}

As seen in Table 23, no uranium was detected in any of the three lifts taken from the surface down to a depth of $22.86 \mathrm{~cm}$ (9 in.). The penetrator rod was buried at $30.48 \mathrm{~cm}$ (12 in.) bgs. The 22.86- to 30.48-cm lift (9-12 in.), directly overlying the penetrator rod, had a low total concentration of uranium. The majority of this uranium was found in the finest $(<0.30 \mathrm{~mm})$ size fraction (74 percent). The trend at this depth was of increasing mass of uranium in each smaller size fraction, from 0 to 74 percent. The 30.48to $38.10-\mathrm{cm}$ lift (12-15 in.), directly beneath the penetrator rod, had a much higher total concentration of uranium. The pattern of distribution of the uranium was the same as in the overlying lift, however, with the largest size fraction holding 4 percent of the uranium, by mass, and increasing with each smaller size fraction up to 84 percent of the total uranium, by mass, in the smallest size fraction.

Additional data on the analysis of the soil size fractions produced by wet sieve separation of the DU Garden soil are available in Tables C9 to C13. 
Table 22. Uranium concentration and percent of the total uranium in the different size fractions of soil from Range 20 as determined through wet sieve separation.

\begin{tabular}{|c|c|c|c|c|c|c|c|c|}
\hline \multirow[t]{2}{*}{ Size Fraction } & \multicolumn{3}{|c|}{$\begin{array}{l}\text { U Concentration } \\
\qquad(\mathrm{mg} / \mathrm{kg})\end{array}$} & \multirow{2}{*}{$\begin{array}{c}\text { U Concentra- } \\
\text { tion } \\
\text { Avg, } n=3\end{array}$} & \multirow[t]{2}{*}{ Stdev } & \multirow[t]{2}{*}{$\begin{array}{l}\text { Avg Soil } \\
\text { Mass (Kg) }\end{array}$} & \multirow[t]{2}{*}{$\begin{array}{c}\text { Avg DU Mass } \\
(\mathrm{mg})\end{array}$} & \multirow[t]{2}{*}{$\begin{array}{l}\text { Avg } \% \text { Total U per } \\
\text { Size Fraction }\end{array}$} \\
\hline & $20-1$ & $20-2$ & $20-3$ & & & & & \\
\hline$>4.76 \mathrm{~mm}$ & $0.05 *$ & $0.05 *$ & $0.05 *$ & 0.05 & 0.00 & 0.20 & 0.01 & $0.00 \%$ \\
\hline$<4.76 \mathrm{~mm}$ to $>2.00 \mathrm{~mm}$ & $0.05 *$ & $2,027.33$ & $2,805.33$ & $1,610.90$ & $1,448.26$ & 0.16 & 266.58 & $2.23 \%$ \\
\hline$<0.30 \mathrm{~mm}$ & $11,716.67$ & $20,573.33$ & $18,690.00$ & $16,993.33$ & $4,665.74$ & 0.31 & $5,321.75$ & $49.39 \%$ \\
\hline Total & $26,950.10$ & $38,700.71$ & $41,242.05$ & $35,630.95$ & & 0.96 & $10,594.86$ & \\
\hline
\end{tabular}


Table 23. Concentration and percent of the total uranium in the different size fractions of soil from the five excavation depths of an intact DU rod buried at 12 in. $(22.86 \mathrm{~cm})$, determined through wet sieve separation.

\begin{tabular}{|c|c|c|c|c|c|c|c|c|c|c|c|}
\hline \multirow[t]{2}{*}{ Size Fraction } & \multicolumn{5}{|c|}{$\begin{array}{l}\text { Concentration of U per Sample (mg/kg) } \\
\text { (in 3-inch increments bgs) }\end{array}$} & \multicolumn{2}{|c|}{$\begin{array}{l}\text { Soil Mass per Frac- } \\
\text { tion }\end{array}$} & \multicolumn{2}{|c|}{$\begin{array}{l}\text { mg of Du per Frac- } \\
\text { tion }\end{array}$} & \multicolumn{2}{|c|}{$\begin{array}{c}\text { \% Total U per Size Fraction at } \\
\text { Depth }\end{array}$} \\
\hline & $\begin{array}{c}1 \\
0- \\
7.62 \\
\mathrm{~cm}\end{array}$ & $\begin{array}{c}2 \\
7.62- \\
15.24 \\
\mathrm{~cm}\end{array}$ & $\begin{array}{c}3 \\
15.24- \\
22.86 \\
\mathrm{~cm}\end{array}$ & $\begin{array}{c}4 \\
22.86- \\
30.48 \mathrm{~cm}\end{array}$ & $\begin{array}{c}5 \\
30.48- \\
38.10 \\
\mathrm{~cm}\end{array}$ & $\begin{array}{c}4 \\
22.86- \\
30.48 \\
\mathrm{~cm}\end{array}$ & $\begin{array}{c}5 \\
30.48- \\
38.10 \\
\mathrm{~cm}\end{array}$ & \begin{tabular}{|c|}
4 \\
$22.86-$ \\
30.48 \\
$\mathrm{~cm}$
\end{tabular} & $\begin{array}{c}5 \\
30.48- \\
38.10 \\
\mathrm{~cm}\end{array}$ & $\begin{array}{c}4 \\
22.86-30.48 \\
\mathrm{~cm}\end{array}$ & $\begin{array}{c}5 \\
30.48-38.10 \\
\mathrm{~cm}\end{array}$ \\
\hline$>4.76 \mathrm{~mm} * *$ & $0.05 *$ & $0.05 *$ & $0.05 *$ & $0.05^{*}$ & $8,000.00$ & 0.11 & 0.15 & 0.01 & $1,200.00$ & $0.00 \%$ & $3.80 \%$ \\
\hline$<4.76 \mathrm{~mm}$ to $>2.00 \mathrm{~mm}$ & 0.05 & 0.05 & 0.05 & 326.83 & 385.17 & 0.07 & 0.07 & 22.55 & 28.12 & $2.41 \%$ & $0.09 \%$ \\
\hline$<2.00 \mathrm{~mm}$ to $>0.30 \mathrm{~mm}$ & 0.05 & 0.05 & 0.05 & $1,866.00$ & $34,833.33$ & 0.12 & 0.11 & 239.92 & $3,971.00$ & $23.97 \%$ & $12.56 \%$ \\
\hline$<0.30 \mathrm{~mm}$ & 0.05 & 0.05 & 0.05 & $1,432.33$ & $51,376.67$ & 0.48 & 0.51 & 687.52 & $26,407.61$ & $73.61 \%$ & $83.55 \%$ \\
\hline Total & & & & $3,625.21$ & $94,595.17$ & 0.78 & 0.85 & 934.00 & $31,606.73$ & $100.00 \%$ & $100.00 \%$ \\
\hline
\end{tabular}




\section{Heavy liquid density separation (HLDS)}

Heavy liquid density separation (HLDS) produced three fractions of soil separated by density: the sinking (bottom) fraction, the floating fraction, and the suspended fraction. The sample referred to as "floating" represents the material that was able to be scooped off the top of the heavy liquid using a spatula tip. The sample referred to as "suspended" represents the material that remained in the heavy liquid. The suspended material was decanted from the bottom fraction and removed from the heavy liquid by filtration. The sample referred to as "bottom" is the material that sank to the bottom of the separation vessel representing material that could conceivably be removed via density separation. An example of the appearance of these size fractions is shown in Figure 15. Because the separation process produces very small sample amounts, they were not ground in the field. The samples were ground, digested, and analyzed in the laboratory.

Tables 24, 25, 26, and 27 show the concentration of DU in each of these fractions for the Catch Box, the Retention Pond, Range 20, and the DU Garden, respectively. Additional data from the analysis of the soil fractions derived from HLDS separation of these soils are available in Appendix D. Because a polytungstate heavy liquid was used for the separation, the tungsten concentrations found in the samples and reported in Appendix D are artificially high.

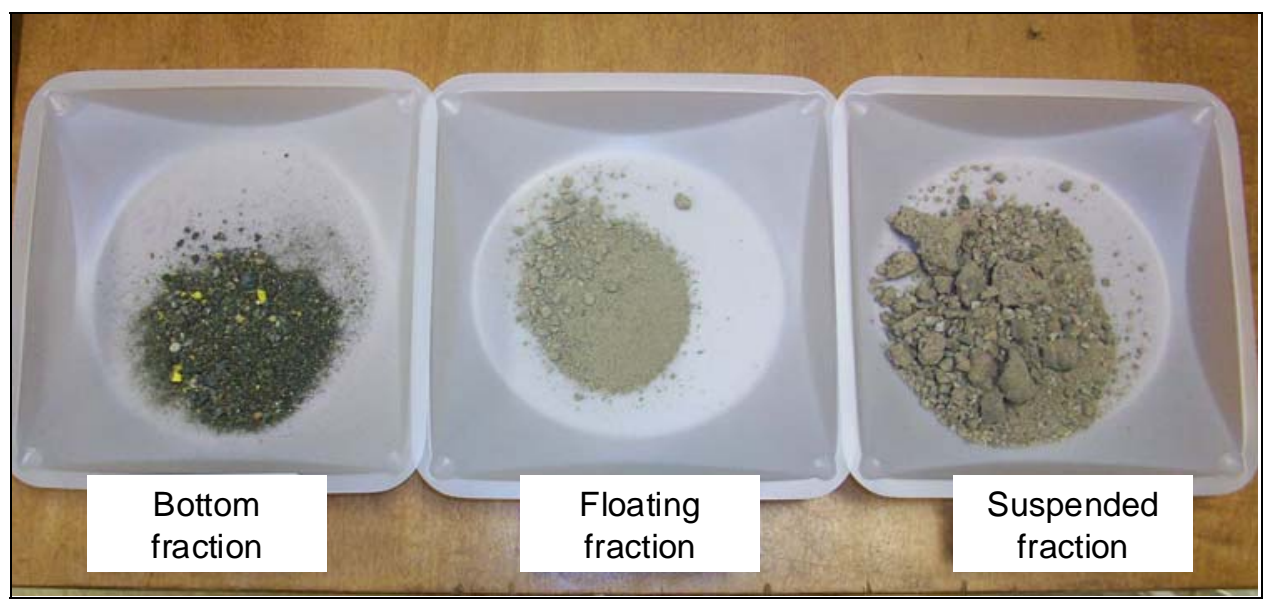

Figure 15. Size fractions obtained through HLDS. These fractions are from a Catch Box soil sample. Note the yellow particles in the bottom fraction.

\section{Background}

No uranium was detected in any of the replicates of size fractions produced by heavy liquid density separation of the background soil samples. 
Additional data from analysis of the background soil fractions can be found in Tables D1 through D4.

Catch Box

Table 24 presents the uranium concentrations of the triplicate digestion and analysis of the density-separated Catch Box soil along with the percent uranium in each fraction, by mass. As determined by HLDS, 84 percent of the total uranium, by mass, from the Catch Box soil was held in the bottom (the densest) fraction. Only 16 percent of the uranium was in the least dense (floating and suspended) fractions.

Additional data from the analysis of the soil fractions produced by HLDS separation of the Catch Box soils can be found in Tables D5 through D8. Because a polytungstate heavy liquid was used for the separation, the tungsten concentrations found in the samples and reported in Appendix D are artificially high.

\section{Retention Pond}

No uranium was detected in the bottom fraction of the Retention Pond sediment (Table 25). All of the uranium in this sample (100 percent, by mass) was held in the suspended/ floating fractions, with 64 percent, by mass, in the floating fraction.

Additional data from the analysis of the soil fractions produced by HLDS separation of the Retention Pond soil can be found in Table D18. Because a polytungstate heavy liquid was used for the separation, the tungsten concentrations found in the samples and reported in Appendix D are artificially high. 
Table 24. Concentration of uranium and the percentage of total uranium in each density fraction determined by heavy liquid density separation (HLDS) of soil from the Catch Box site

\begin{tabular}{|c|c|c|c|c|c|c|c|c|}
\hline \multirow[t]{2}{*}{$\begin{array}{l}\text { Density } \\
\text { Fraction }\end{array}$} & \multicolumn{3}{|c|}{$\begin{array}{l}\text { U Concentration per Sample* } \\
\qquad(\mathrm{mg} / \mathrm{kg})\end{array}$} & \multirow[t]{2}{*}{$\begin{array}{l}\text { U Concentration } \\
\text { (Avg, } n=3)\end{array}$} & \multirow[t]{2}{*}{ Stdev } & \multirow[t]{2}{*}{$\begin{array}{c}\text { Avg Soil Mass } \\
\text { (Kg) }\end{array}$} & \multirow[t]{2}{*}{$\begin{array}{l}\text { Avg DU Mass } \\
\text { (mg) }\end{array}$} & \multirow{2}{*}{$\begin{array}{l}\text { Avg \% Total U } \\
\text { per Size } \\
\text { Fraction }\end{array}$} \\
\hline & CB 1 & CB 2 & CB 3 & & & & & \\
\hline Suspended & 150.25 & 581.84 & 214.05 & 315.38 & 232.96 & 0.03 & 9.31 & $5.14 \%$ \\
\hline Floating & 204.62 & 808.45 & 275.05 & 429.37 & 330.17 & 0.05 & 23.73 & $10.71 \%$ \\
\hline
\end{tabular}


Table 25. Concentration of uranium and the percentage of total uranium in each density fraction determined by heavy liquid density separation (HLDS) and laboratory grinding of soil from the Retention Pond site.

\begin{tabular}{|l|c|c|c|c|}
\hline Density Fraction & $\begin{array}{c}\text { Concentration of U } \\
\text { in Each Size } \\
\text { Fraction } \\
(\mathrm{mg} / \mathrm{Kg})\end{array}$ & $\begin{array}{c}\text { Soil Mass per } \\
\text { Size Fraction } \\
(\mathrm{Kg})\end{array}$ & $\begin{array}{c}\text { Mass of DU per } \\
\text { Size Fraction } \\
(\mathrm{mg})\end{array}$ & $\begin{array}{c}\text { \% Total U per } \\
\text { Size Fraction }\end{array}$ \\
\hline Bottom* & 0.00 & 0.00 & 0.00 & $0.00 \%$ \\
\hline Suspended & 250.00 & 0.057 & 14.25 & $36.91 \%$ \\
\hline Floating & 276.77 & 0.088 & 24.36 & $63.09 \%$ \\
\hline Total & 526.77 & 0.145 & 38.61 & $100.00 \%$ \\
\hline *No soil was present in the bottom fraction for digestion and analysis \\
\hline
\end{tabular}

Range 20

The Range 20 soil samples separated by HLDS showed that a majority of the uranium (84 percent) was held in the bottom (most dense) soil fraction (Table 26). Sixteen percent of the total uranium, by mass, was found in the two less dense fractions.

Additional data from the analysis of the soil fractions produced by HLDS separation of the Range 20 soils can be found in Tables D13 through D16. Because a polytungstate heavy liquid was used for the separation, the tungsten concentrations found in the samples and reported in Appendix D are artificially high.

\section{DU Garden}

As seen in Table 27, in the 22.86- to 30.48-cm (9- to 12-in.) lift, the soil directly above the buried penetrator rod, no uranium was detected in the bottom fraction. All of the uranium was held in the suspended/ floating fractions; 25 and 75 percent, respectively. In contrast, the area directly beneath the buried rod, 30.48 to $38.10 \mathrm{~cm}$ (12-15 in.) bgs, held 93 percent of the total uranium, by mass, in the bottom fraction.

Additional data from the analysis of the soil fractions produced by HLDS separation of the DU Garden soils can be found in Tables D9 through D13. Because a polytungstate heavy liquid was used for the separation, the tungsten concentrations found in the samples and reported in Appendix D are artificially high. 
Table 26. Concentration of uranium and the percentage of total uranium in each density fraction determined by heavy liquid density separation (HLDS) of soil from the Range 20 sites.

\begin{tabular}{|c|c|c|c|c|c|c|c|c|}
\hline \multirow[t]{2}{*}{$\begin{array}{l}\text { Density } \\
\text { Fraction }\end{array}$} & \multicolumn{3}{|c|}{$\begin{array}{l}\text { U Concentration per Sample } \\
\qquad(\mathrm{mg} / \mathrm{kg})\end{array}$} & \multirow{2}{*}{$\begin{array}{c}U \\
\text { Concentration } \\
(\text { avg, } n=3)\end{array}$} & \multirow[t]{2}{*}{ Stdev } & \multirow[t]{2}{*}{$\begin{array}{c}\text { Avg Soil Mass } \\
(\mathrm{kg})\end{array}$} & \multirow[t]{2}{*}{$\begin{array}{l}\text { Avg DU Mass } \\
(\mathrm{mg})\end{array}$} & \multirow{2}{*}{$\begin{array}{l}\text { Avg \% Total U } \\
\text { per Size } \\
\text { Fraction }\end{array}$} \\
\hline & $20-1 *$ & $20-2$ & $20-3$ & & & & & \\
\hline Bottom & $189,688.89$ & $446,400.00$ & $296,633.33$ & $310,907.41$ & $128,949.45$ & 0.003 & $1,017.03$ & $83.83 \%$ \\
\hline Suspended & $2,446.67$ & $2,910.00$ & $4,215.33$ & $3,190.67$ & 917.13 & 0.016 & 53.15 & $4.66 \%$ \\
\hline Floating & $2,346.45$ & 979.70 & $1,245.67$ & $1,523.94$ & 724.62 & 0.083 & 130.25 & $11.51 \%$ \\
\hline Total & $194,482.00$ & $450,289.70$ & $302,094.33$ & $315,622.01$ & $128,439.26$ & & & \\
\hline
\end{tabular}


Table 27. Concentration of uranium and the percentage of total uranium in each density fraction from each soil lift as determined by heavy liquid density separation (HLDS) of soil from the DU Garden site

\begin{tabular}{|c|c|c|c|c|c|c|c|c|c|c|c|}
\hline \multirow[t]{2}{*}{ Size Fraction } & \multicolumn{5}{|c|}{$\begin{array}{c}\text { Concentration of U } \\
(\mathrm{mg} / \mathrm{kg}) \\
\text { (in 3-in. increments bgs) }\end{array}$} & \multicolumn{2}{|c|}{$\begin{array}{l}\text { Soil Mass } \\
\text { (mg) }\end{array}$} & \multicolumn{2}{|c|}{$\mathrm{mg}$ of $\mathrm{Du}$} & \multicolumn{2}{|c|}{ \% Total U } \\
\hline & $\begin{array}{c}1 * \\
0- \\
7.62 \\
\mathrm{~cm}\end{array}$ & $\begin{array}{c}2 * \\
7.62- \\
15.24 \mathrm{~cm}\end{array}$ & $\begin{array}{c}3^{*} \\
15.24- \\
22.86 \mathrm{~cm}\end{array}$ & $\begin{array}{c}4 \\
22.86-30.48 \\
\mathrm{~cm}\end{array}$ & $\begin{array}{c}5 \\
30.48-38.10 \\
\mathrm{~cm}\end{array}$ & $\begin{array}{c}4 \\
22.86- \\
30.48 \mathrm{~cm}\end{array}$ & $\begin{array}{c}5 \\
30.48- \\
38.10 \\
\mathrm{~cm}\end{array}$ & $\begin{array}{c}4 \\
22.86- \\
30.48 \mathrm{~cm}\end{array}$ & $\begin{array}{c}5 \\
30.48- \\
38.10 \\
\mathrm{~cm}\end{array}$ & $\begin{array}{c}4 \\
22.86-30.48 \\
\mathrm{~cm}\end{array}$ & $\begin{array}{c}5 \\
30.48- \\
38.10 \\
\mathrm{~cm}\end{array}$ \\
\hline Bottom & 0.05 & 0.05 & 0.05 & 0.05 & $624,766.67$ & 0.001 & 0.05 & 0.00 & $3,123.83$ & $0.00 \%$ & $93.02 \%$ \\
\hline Suspended & 0.05 & 0.05 & 0.05 & 536.83 & $1,805.00$ & 0.029 & 0.017 & 15.57 & 30.69 & $24.53 \%$ & $0.91 \%$ \\
\hline Floating & 0.05 & 0.05 & 0.05 & 656.27 & $2,424.33$ & 0.073 & 0.084 & 47.91 & 203.64 & $75.47 \%$ & $6.06 \%$ \\
\hline Total & 0.05 & 0.05 & 0.05 & $1,193.15$ & $628,996.00$ & 0.103 & 0.106 & 63.48 & $3,358.16$ & $100.00 \%$ & $100.00 \%$ \\
\hline
\end{tabular}

*None of the soil samples from the top $22.86 \mathrm{~cm}$ (9 in.) of soil above the penetrator contained uranium above the $0.05-p p m$ laboratory reporting limit,

which was used in place of non-detect for statistical analysis. 


\section{Water/momentum density separation}

Water/momentum density separation using a Wilfley Table produces a range of soil fractions of varied density. This separation method was used to process the YPG soils from the Catch Box, Range 20, and the DU Garden sites. Two different sieve sizes, the \#20 and the \#50 mesh, corresponding to the $0.841-\mathrm{mm}$ and $0.297-\mathrm{mm}$ size soil particle, were used as initial samples for the Wilfley Table separation process. Two particle size ranges produced using these sieves were separated, digested, and analyzed (the $<0.841-\mathrm{mm}$ to $>0.297-\mathrm{mm}$ size fraction and the $<0.297-\mathrm{mm}$ size fraction). Separation results using these two soil sieve size fractions are shown in Tables 28 through 32. Additional data resulting from analysis of the soil fractions produced by Wilfley Table water/ momentum density separation of the YPG soils are available in Appendix E.

Figure 16 is an example of the appearance of the soil fractions produced by Wilfley Table water/ momentum density separation.

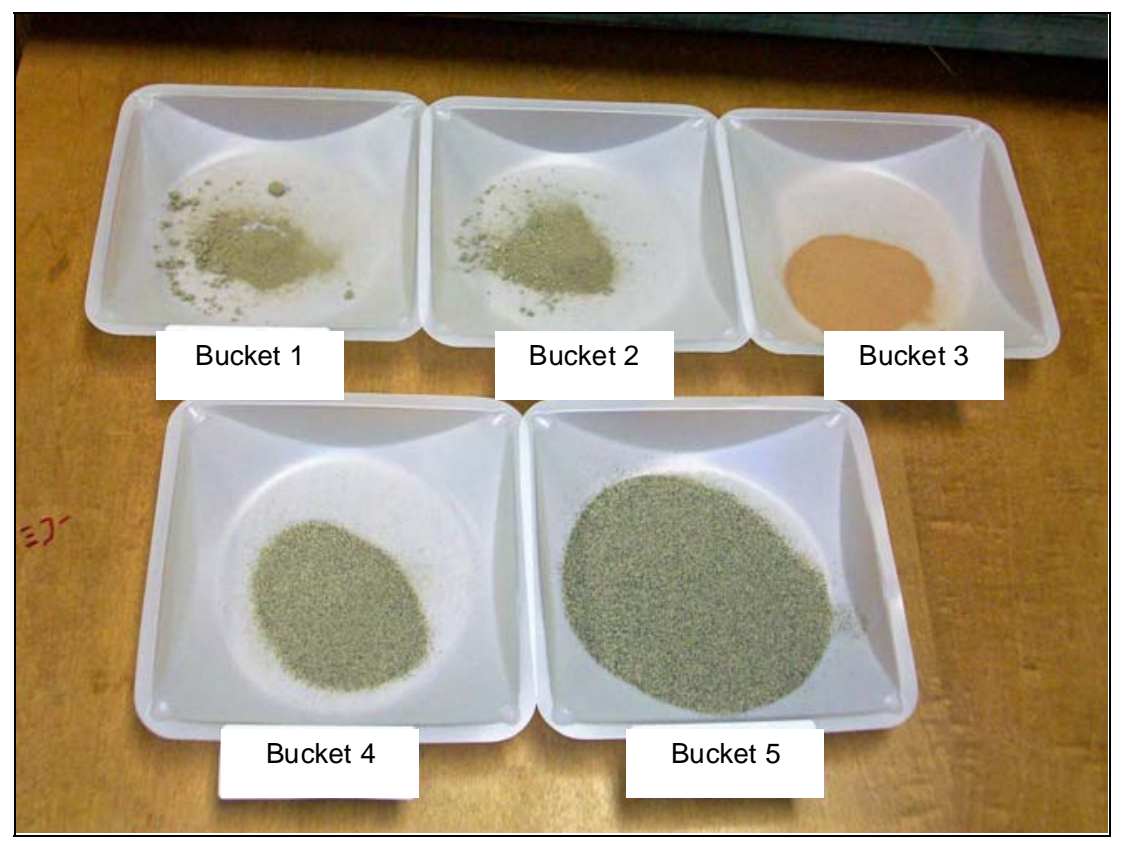

Figure 16. Size fractions obtained by Wilfley Table separation of a Catch Box soil sample identified from smallest density to the greatest density fraction by bucket (Bucket 1 to Bucket 5, respectively).

\section{Background}

No uranium was detected in any of the replicates of size fractions produced by heavy liquid density separation of the background soil samples. 
Additional data from analysis of the background soil fractions can be found in Tables E1 through E4.

Catch Box

As seen in Table 28, 95 percent of the total concentration of uranium in the Catch Box soil size fraction between 0.297 and $0.841 \mathrm{~mm}$, as determined by water/ momentum separation performed on the Wilfley Table, was found in the last two buckets, representing the soil fractions with the highest density. This mass of DU represents 98 percent of the soil sample mass. Bucket 5 contained 61 percent of the DU or 86 percent of the soil mass. Separation of the finer fraction of the soil (less than $0.297 \mathrm{~mm}$ in size, Table 29) also showed the highest total concentration of uranium (58 percent) was in Bucket 5, which comprised 67 percent of the soil sample mass.

Additional data from the analysis of the soil fractions produced by Wilfley Table separation of the Catch Box soils can be found in Table E5.

Table 28. Uranium concentration in soil size fractions determined by Wilfley Table density separation of the $<0.841-\mathrm{mm}$ to $>0.297-\mathrm{mm}$ size fraction of the Catch Box 1 composite soil sample.

\begin{tabular}{|l|c|c|c|c|c|}
\hline $\begin{array}{c}\text { Size/Density } \\
\text { Fraction } \\
(\text { Bucket \#) }\end{array}$ & $\begin{array}{c}\text { Concentration of } \\
\text { ( } \mathrm{mg} / \mathrm{kg})\end{array}$ & $\begin{array}{c}\text { Soil Mass } \\
(\mathrm{kg})\end{array}$ & Mg of DU & \% of Total DU & $\begin{array}{c}\text { \% of Total } \\
\text { Soil Mass }\end{array}$ \\
\hline 1 & $3,254.50$ & 0.001 & 3.25 & $1.20 \%$ & $0.46 \%$ \\
\hline 2 & $4,041.00$ & 0.001 & 4.04 & $1.49 \%$ & $0.46 \%$ \\
\hline 3 & $4,019.50$ & 0.001 & 4.02 & $1.49 \%$ & $0.46 \%$ \\
\hline 4 & $2,437.00$ & 0.001 & 2.44 & $0.90 \%$ & $0.46 \%$ \\
\hline 5 & 879.93 & 0.187 & 164.55 & $60.84 \%$ & $86.18 \%$ \\
\hline 6 & $3,544.30$ & 0.026 & 92.15 & $34.07 \%$ & $11.98 \%$ \\
\hline Total & $17,311.80$ & 0.217 & 270.45 & $100.00 \%$ & \\
\hline
\end{tabular}


Table 29. Uranium concentration in soil size fractions determined by Wilfley Table density separation of the $<0.297-\mathrm{mm}$ size fractions of the Catch Box 1 composite soil sample.

\begin{tabular}{|l|c|c|c|c|c|}
\hline $\begin{array}{c}\text { Size/Density } \\
\text { Fraction } \\
(\text { Bucket \#) }\end{array}$ & $\begin{array}{c}\text { Concentration of } \\
\mathbf{( m g / k g )}\end{array}$ & $\begin{array}{c}\text { Soil Mass } \\
(\mathrm{kg})\end{array}$ & Mg of DU & \% of Total DU & $\begin{array}{c}\text { \% of Total } \\
\text { Soil Mass }\end{array}$ \\
\hline 1 & $3,098.67$ & 0.010 & 30.99 & $7.04 \%$ & $4.88 \%$ \\
\hline 2 & $3,322.67$ & 0.010 & 33.23 & $7.54 \%$ & $4.88 \%$ \\
\hline 3 & $6,560.67$ & 0.010 & 65.61 & $14.90 \%$ & $4.88 \%$ \\
\hline 4 & 460.30 & 0.032 & 14.73 & $3.34 \%$ & $15.61 \%$ \\
\hline 5 & 1875.67 & 0.137 & 256.97 & $58.35 \%$ & $66.83 \%$ \\
\hline 6 & $6,481.00$ & 0.006 & 38.89 & $8.83 \%$ & $2.93 \%$ \\
\hline Total & $21,798.98$ & 0.205 & 440.40 & $100.00 \%$ & \\
\hline
\end{tabular}

Range 20

Table 30 details the water/ momentum density separation of the $<0.841-\mathrm{mm}$ to $>0.297-\mathrm{mm}$ size fraction of the Range 20 soil. This larger size fraction held 96 percent of the total uranium in the two densest fractions, buckets 5 and 6 . Bucket 5 contained 70 percent of the total soil mass from the sample. Buckets 1 to 4 together contained $<5$ percent of the total uranium, by mass. The smaller soil size fraction $(<0.297 \mathrm{~mm}$, Table 31) held 83 percent of the total uranium in the two densest fractions, again, with a relatively small amount of uranium in the other, less dense, fractions. Bucket 5 again held the highest amount of soil, 41 percent of the total soil mass of the sample.

Table 30. Uranium concentration in soil size fractions determined by Wilfley Table water/momentum separation of the $<0.841-\mathrm{mm}$ to $>0.297-\mathrm{mm}$ size fraction of the Range 20 composite soil samples.

\begin{tabular}{|l|c|c|c|c|c|}
\hline $\begin{array}{c}\text { Size/Density } \\
\text { Fraction } \\
(\text { Bucket \#) }\end{array}$ & $\begin{array}{c}\text { Concentration of } \\
\mathbf{( m g / k g}\end{array}$ & $\begin{array}{c}\text { Soil Mass } \\
(\mathrm{kg})\end{array}$ & Mg of DU & \% of Total DU & $\begin{array}{c}\text { \% of Soil } \\
\text { Mass }\end{array}$ \\
\hline 1 & $5,717.00$ & 0.001 & 5.72 & $0.25 \%$ & $0.53 \%$ \\
\hline 2 & $3,390.67$ & 0.004 & 13.56 & $0.60 \%$ & $2.12 \%$ \\
\hline 3 & $1,899.00$ & 0.011 & 20.89 & $0.92 \%$ & $5.82 \%$ \\
\hline 4 & $1,842.00$ & 0.030 & 55.26 & $2.43 \%$ & $15.87 \%$ \\
\hline 5 & $14,000.00$ & 0.132 & $1,848.00$ & $81.23 \%$ & $69.84 \%$ \\
\hline 6 & $30,146.67$ & 0.011 & 331.61 & $14.58 \%$ & $5.82 \%$ \\
\hline Total & $56,995.34$ & 0.190 & $2,275.04$ & $100.00 \%$ & \\
\hline
\end{tabular}


Table 31. Uranium concentration in soil size fractions determined by Wilfley Table density separation of the $<0.297-\mathrm{mm}$ size fractions of the Range 20 composite soil sample.

\begin{tabular}{|l|c|c|c|c|c|}
\hline $\begin{array}{c}\text { Size/Density } \\
\text { Fraction } \\
\text { (Bucket \#) }\end{array}$ & $\begin{array}{c}\text { Concentration of } \\
\mathbf{( m g / k g}\end{array}$ & $\begin{array}{c}\text { Soil Mass } \\
(\mathrm{kg})\end{array}$ & Mg of DU & \% of Total DU & $\begin{array}{c}\text { \% of Soil } \\
\text { Mass }\end{array}$ \\
\hline 1 & $6,096.00$ & 0.012 & 73.15 & $2.75 \%$ & $5.45 \%$ \\
\hline 2 & 943.63 & 0.045 & 42.46 & $1.59 \%$ & $20.45 \%$ \\
\hline 3 & $5,788.67$ & 0.040 & 231.55 & $8.69 \%$ & $18.18 \%$ \\
\hline 4 & $3,484.33$ & 0.028 & 97.56 & $3.66 \%$ & $12.73 \%$ \\
\hline 5 & $19,653.33$ & 0.090 & $1,768.80$ & $66.39 \%$ & $40.91 \%$ \\
\hline 6 & $90,136.67$ & 0.005 & 450.68 & $16.92 \%$ & $2.27 \%$ \\
\hline Total & $126,102.63$ & 0.220 & $2,664.21$ & $100.00 \%$ & \\
\hline
\end{tabular}

Additional data from the analysis of the soil fractions produced by Wilfley Table separation of the Range 20 soil can be found in Table E7.

\section{DU Garden}

Tables 32 and 33 detail the water/ momentum separation of two size fractions of the 30.48- to 38.10-cm (12- to 15-in.) lift of the DU Garden soil, the $<0.841-\mathrm{mm}$ to $>0.297-\mathrm{mm}$ size and the $<0.297-\mathrm{mm}$ size, respectively. The larger size fraction held 58 percent of the total uranium in a fraction with high density (bucket 5), which was only 38 percent of the total soil mass.

The smaller size fraction treated by Wilfley Table separation (Table 33) held 67 percent of the total uranium divided evenly between two highdensity fractions (buckets 5 and 6). These two fractions comprised 43 percent of the total soil mass of the sample.

Additional data from the analysis of the soil fractions produced by Wilfley Table separation of the DU Garden Lift 5 soil can be found in Table E6. 
Table 32. Uranium concentration in soil size fractions determined by Wilfley Table water/momentum density separation of the $<0.841-\mathrm{mm}$ to $>0.297-\mathrm{mm}$ size fraction of the 30.48- to 8.10-cm (12- to 15-in.) lift collected at the DU Garden.

\begin{tabular}{|l|c|c|c|c|c|}
\hline $\begin{array}{c}\text { Size/Density } \\
\text { Fraction } \\
(\text { Bucket \#) }\end{array}$ & $\begin{array}{c}\text { Concentration of } \\
\mathbf{( m g / k g}\end{array}$ & $\begin{array}{c}\text { Soil Mass } \\
(\mathrm{kg})\end{array}$ & Mg of DU & \% of Total DU & $\begin{array}{c}\text { \% of Soil } \\
\text { Mass }\end{array}$ \\
\hline 1 & $25,583.33$ & 0.023 & 588.42 & $3.75 \%$ & $5.84 \%$ \\
\hline 2 & $23,630.00$ & 0.030 & 708.90 & $4.52 \%$ & $7.61 \%$ \\
\hline 3 & $11,620.00$ & 0.107 & $1,243.34$ & $7.93 \%$ & $27.16 \%$ \\
\hline 4 & $13,226.67$ & 0.071 & 939.09 & $5.99 \%$ & $18.02 \%$ \\
\hline 5 & $60,490.00$ & 0.150 & $9,073.50$ & $57.88 \%$ & $38.07 \%$ \\
\hline 6 & $256,400.00$ & 0.012 & $3,076.80$ & $19.63 \%$ & $3.05 \%$ \\
\hline 7 & $46,300.00$ & 0.001 & 46.30 & $0.30 \%$ & $0.25 \%$ \\
\hline Total & $437,250.00$ & 0.394 & $15,676.35$ & $100.00 \%$ & \\
\hline
\end{tabular}

Table 33. Uranium concentration in soil size fractions determined by Wilfley Table water/momentum separation of the $<0.297-\mathrm{mm}$ size fractions of the 30.48 - to $38.10-\mathrm{cm}$ (12to 15-in.) lift collected at the DU Garden.

\begin{tabular}{|l|c|c|c|c|c|}
\hline $\begin{array}{c}\text { Size/Density } \\
\text { Fraction } \\
(\text { Bucket \#) }\end{array}$ & $\begin{array}{c}\text { Concentration of } \\
\mathbf{( m g / k g )}\end{array}$ & $\begin{array}{c}\text { Soil Mass } \\
(\mathrm{kg})\end{array}$ & Mg of DU & \% of Total DU & $\begin{array}{c}\text { \% of Soil } \\
\text { Mass }\end{array}$ \\
\hline 1 & $14,400.00$ & 0.005 & 72.00 & $1.57 \%$ & $1.99 \%$ \\
\hline 2 & $12,840.00$ & 0.054 & 693.36 & $15.12 \%$ & $21.50 \%$ \\
\hline 3 & $10,943.33$ & 0.044 & 481.51 & $10.50 \%$ & $17.52 \%$ \\
\hline 4 & $6,412.33$ & 0.039 & 250.08 & $5.45 \%$ & $15.53 \%$ \\
\hline 5 & $16,316.67$ & 0.100 & 1631.67 & $35.59 \%$ & $39.81 \%$ \\
\hline 6 & $161,733.33$ & 0.009 & 1455.60 & $31.75 \%$ & $3.58 \%$ \\
\hline 7 & $2,846.00$ & 0.000 & 0.57 & $0.01 \%$ & $0.08 \%$ \\
\hline Total & $225,491.66$ & 0.251 & 4584.78 & $100.00 \%$ & \\
\hline
\end{tabular}

Wilfley Table Separation Water

The separation water collected in each density fraction was decanted and analyzed. Uranium concentrations were highest in the buckets collecting the highest percentage of $U$. Additional data from the analysis of the separation water produced from each Wilfley Table separation of the YPG soils can be found in Tables E5 through E7. 


\section{Depleted uranium depth profile in soil}

\section{Uranium concentration}

A DU concentration depth profile was run on a soil core pulled from a control site and from the DU Garden sampling site where a penetrator was buried at $30.5 \mathrm{~cm}$ ( $12 \mathrm{in}$.). Cores were sampled in 7.6-cm (3-in.) increments from the surface to $38.1 \mathrm{~cm}$ ( $15 \mathrm{in}$.) bgs. No DU was found in the control samples. In the DU Garden core, yellow schoepite was noticed at $30.5 \mathrm{~cm}$ (12 in.). Screening was done with a handheld Geiger counter, TA Model TBM-15 (Table 34). Background was 60 counts per minute (cpm). The counts from the DU Garden core increased with depth to $30.5 \mathrm{~cm}$ (12 in.), then decreased back to background at $38.1 \mathrm{~cm}$ (15 in.).

Soil samples were then analyzed in the laboratory for uranium (Table 35). No DU was detected in the first $3 \mathrm{in}$. Nearly $7-\mathrm{mg} / \mathrm{kg}$ was detected at the 7.6- to 15.2-cm (3- to 6-in.) level. Much higher levels of DU were detected in the 15.2- to 22.9-cm (6- to 9-in.) levels and still higher in the 22.9- to 30.5- $\mathrm{cm}$ and 30.5- to 38.1-cm (9- to 12-in.) levels. However, below the 38.1-cm (15-in.) level, no DU was detected. As the penetrator was buried at $30.5 \mathrm{~cm}$ (12 in.), this suggests that the DU migrates upward, with minimal downward movement.

Table 34. Geiger counter readings of the depth profile of the DU Garden core.

\begin{tabular}{|c|c|c|}
\hline Soil Depth in cm bgs (in. bgs) & $\begin{array}{l}\text { Geiger Counter Readings } \\
\text { (cpm) }\end{array}$ & Comments \\
\hline Background & 60 & \\
\hline \multicolumn{3}{|l|}{ DU Garden } \\
\hline Surface & 120 & \\
\hline $0-7.6(0-3)$ & 240 & \\
\hline $7.6-15.2(3-6)$ & 800 & \\
\hline $15.2-22.9(6-9)$ & 1100 & \\
\hline $22.9-30.5(9-12)$ & $50,000 *$ & Schoepite found at $10 \mathrm{in.} \mathrm{bgs}$ \\
\hline $33.0-38.1(12-15)$ & $50,000 *$ & $\begin{array}{l}\text { Background counts re- } \\
\text { established at the } 15 \text {-in. } \\
\text { mark. Schoepite found at } 12 \\
14 \text { in. bgs. }\end{array}$ \\
\hline Over 38.1 (over 15) & 60 & Background \\
\hline
\end{tabular}


Table 35. Depth profile of uranium obtained from the DU Garden sampling site

\begin{tabular}{|c|c|c|c|}
\hline \multirow[t]{2}{*}{ Soil Excavation Lift Number } & \multirow[t]{2}{*}{$\begin{array}{l}\text { Soil Depth } \\
\text { in cm-bgs (in-bgs) }\end{array}$} & \multicolumn{2}{|c|}{$\begin{array}{l}\text { U Concentration } \\
(\mathrm{mg} / \mathrm{kg})\end{array}$} \\
\hline & & Average & Stdev \\
\hline 1 & $0-7.6(0-3)$ & $<0.05^{*}$ & na \\
\hline 2 & $7.6-15.2(3-6)$ & $<0.05^{*}$ & na \\
\hline 3 & $15.2-22.9(6-9)$ & $<0.05^{*}$ & na \\
\hline 4 & $22.9-30.5(9-12)$ & $21,510.00$ & 762.95 \\
\hline 5 & 33.0 - $38.1(12-15)$ & $35,683.33$ & 732.21 \\
\hline 6 & Over 38.1 (over 15) & $<0.05 * *$ & na \\
\hline
\end{tabular}

\section{Sequential extraction}

Each lift of the DU Garden site was then subjected to sequential extraction and analysis in order to investigate the potential availability of the DU in YPG soil. The results are shown in Table 36 and Figure 17. No uranium was detected in any of the residual fractions so these were removed from the table for brevity and clarity. Also, no uranium was detected in any fraction of the shallow surface samples. In the 7.6- to 15.2-cm lift, uranium was detected in one out of three replicates of the Fe-Mn Oxide fraction, which resulted in a high standard deviation. Uranium was detected reliably in both the Carbonate and the OM-Sulfide fractions of the 15.2- to 22.9-cm lift. Uranium was detected at low concentration in the Exchangeable fraction, considered the most bioavailable, only in the 22.9- to 30.5-cm lift, directly above the buried penetrator. 
Table 36. Sequential extraction for depleted uranium through the depth profile of the soil core taken from the DU Garden sampling site.

\begin{tabular}{|c|c|c|c|c|c|c|c|c|c|}
\hline \multirow[t]{2}{*}{ Soil Lift } & \multirow[t]{2}{*}{$\begin{array}{l}\text { Soil Depth } \\
\text { in cm bgs (in. bgs) }\end{array}$} & \multicolumn{8}{|c|}{$\begin{array}{l}\text { Concentration of U by Sequential Extraction Fraction } \\
\qquad(\mathrm{mg} / \mathrm{kg})\end{array}$} \\
\hline & & \multicolumn{2}{|c|}{ Exchangeable } & \multicolumn{2}{|c|}{ Carbonate } & \multicolumn{2}{|c|}{ Fe-Mn Oxide } & \multicolumn{2}{|c|}{ OM-Sulfide } \\
\hline 1 & $0-7.6(0-3)$ & $<0.05 *$ & na & $<0.05 *$ & na & $<0.05 *$ & na & $<0.05^{*}$ & na \\
\hline 2 & $7.6-15.2(3-6)$ & & & & & & & & \\
\hline 5 & $30.5-38.1(12-15)$ & 19.06 & 0.86 & $2,174.00$ & 63.06 & $1,101.13$ & 837.55 & 42.34 & 1.90 \\
\hline
\end{tabular}




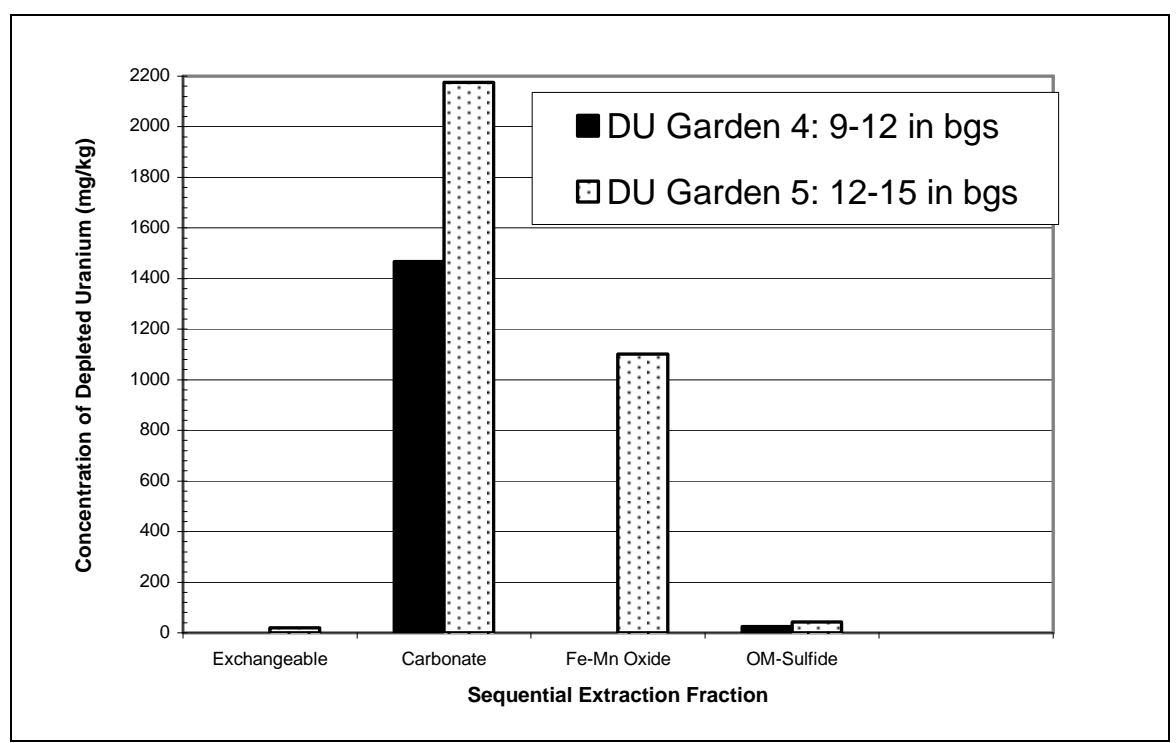

Figure 17. The uranium concentration in sequential extraction fractions of the YPG DU Garden soil, Lifts 4 and 5 , from 9 to 15 in. bgs.

\section{YPG Site Comparison by Sequential Extraction of Depleted Uranium}

The differences in $\mathrm{U}$ concentration in each of the sequential extraction fractions of soil from the DU Garden Lift 4 and 5 were compared to sequential extraction fractions of the other site soils. The sequential extraction of each site soil encompassed the entire soil fraction less than $4.76 \mathrm{~mm}$ in size. The results are shown in Figure 18 and detailed in Table 37. The sites with the higher total U concentrations also had higher concentrations of the more extractable forms. The DU Garden, for example, had high concentrations of $U$ in both the Carbonate and Fe-Mn oxide fractions. Range 20, on the other hand, had a single, Fe-Mn oxide spike. Bioavailability of the metal is generally considered to conform to the extraction sequence. That is, the Exchangeable fraction is the most bioavailable, the Carbonate fraction is more bioavailable than the Fe-Mn Oxide and OM-Sulfide fractions, etc. Additional data on the results of sequential extraction of YPG soils can be found in Appendix F. 


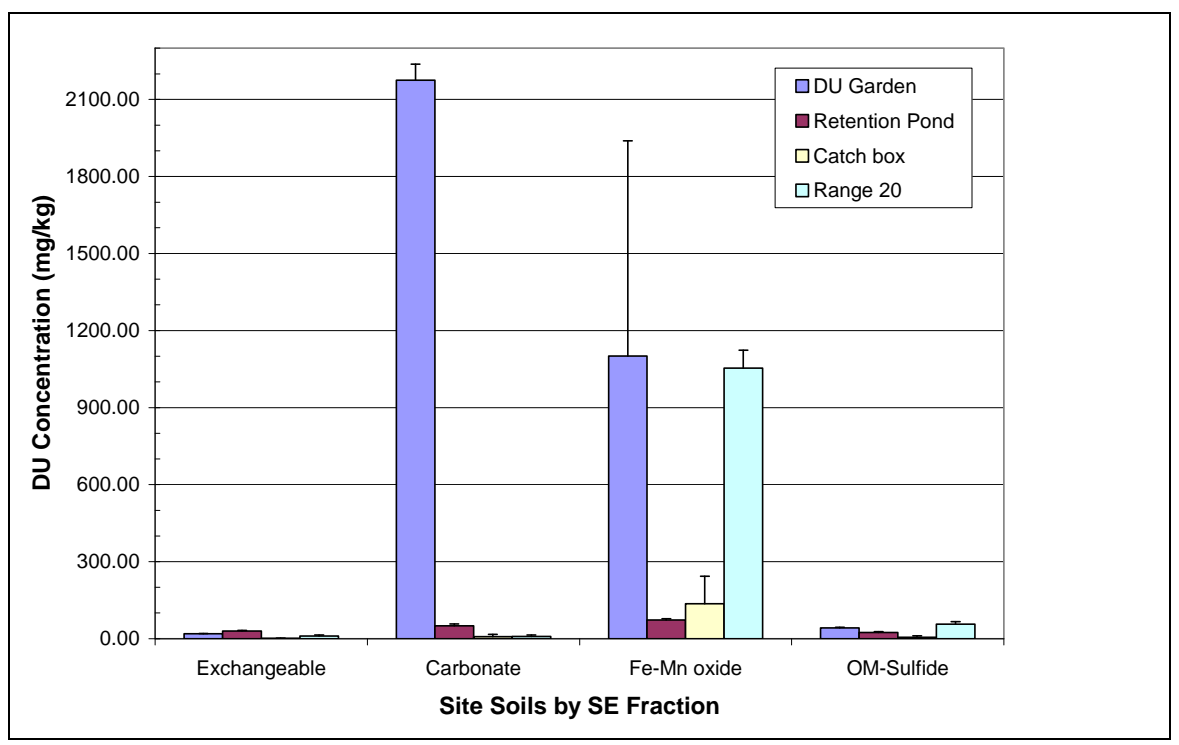

Figure 18. Results of the sequential extraction of DU from soil obtained from different test areas of the Yuma Proving Ground. 
Table 37. Average concentration of uranium in each of the SE fractions from different sampling areas of the YPG vs. sum of the fractions

\begin{tabular}{|l|c|c|c|c|c|c|}
\hline \multirow{2}{*}{ YPG Site } & \multicolumn{5}{c|}{$\begin{array}{c}\text { Concentration of U by SE fraction (mg/kg) } \\
\text { (avg, } \mathrm{n=3})\end{array}$} \\
\cline { 2 - 8 } & Exchangeable & Carbonate & Fe-Mn Oxide & Organic Matter/Sulfide & Residual & Sum of the Fractions \\
\hline Background & $<0.05^{*}$ & $<0.05^{*}$ & $<0.05^{*}$ & $<0.05^{*}$ & $<0.05^{*}$ & $<0.05^{*}$ \\
\hline DU Garden, lift 4 & $<0.05^{*}$ & $1,467.00 \pm 150.14$ & $<0.05^{*}$ & $24.04 \pm 0.47$ & $<0.05^{*}$ & $1,491.04$ \\
\hline DU Garden, lift 5 & $19.06 \pm 0.86$ & $2,174.67 \pm 63.06$ & $1,101.13 \pm 837.55$ & $42.34 \pm 1.90$ & $<0.05^{*}$ & $3,337.20$ \\
\hline Catch Box & $1.83 \pm 0.43$ & $24.77 \pm 40.12$ & $135.78 \pm 106.90$ & $5.77 \pm 5.62$ & $<0.05^{*}$ & 151.05 \\
\hline Range 20 & $10.68 \pm 3.40$ & $8.50 \pm 5.56$ & $1,053.70 \pm 69.92$ & $56.29 \pm 10.16$ & $<0.05^{*}$ & $1,129.16$ \\
\hline Retention Pond & $29.45 \pm 3.06$ & $50.35 \pm 6.87$ & $72.10 \pm 6.15$ & $24.23 \pm 2.47$ & $<0.05^{*}$ & 176.13 \\
\hline *The reporting limit is used in place of non-detect value. & & & & \\
\hline
\end{tabular}




\section{Discussion}

\section{Comparison of DU Concentrations from the Four Sites}

The various sampling sites at YPG allowed access to DU exposed to different degrees of weathering/ aging (Table 38). The soil from these sites, with the exception of the Retention Pond, was sieved using a 4.76- $\mathrm{mm}$ sieve. Large particles retained on the sieve $(>4.76 \mathrm{~mm})$ were checked by GeigerMueller counter for the presence of uranium. Uranium comprised 15 percent of this largest size fraction of the Catch Box soil. The Range 20 and DU Garden soils had uranium present in the form of intact penetrators in this largest size fraction. In Range 20, 17 percent, by mass, of the U present was seen in the largest soil size fraction. While no uranium was found in the upper lifts of the DU Garden penetrator rod excavation, when the levels were reached that surrounded the rod, the $U$ in the largest size fraction increased to 73-75 percent, by mass. The Retention Pond was created specifically to hold the soil fines carried by runoff water from the Catch Box. This site also did not have uranium in the largest size soil fraction. As the soil and the associated uranium contamination age together, the uranium becomes associated with the smaller size soil fractions.

Table 38. Comparison of uranium concentration in the $>4.76-\mathrm{mm}$ soil fraction of the YPG soils.

\begin{tabular}{|l|c|l|}
\hline Site & \multicolumn{1}{|c|}{ Age } & \multicolumn{1}{c|}{ U Concentration } \\
\hline Catch box & 18 months & $\begin{array}{l}15 \% \text { of the mass of the largest particle size } \\
\text { soil fraction. }\end{array}$ \\
\hline Catch Box Retention Pond & $\begin{array}{c}\text { Unknown number } \\
\text { of years }\end{array}$ & $\begin{array}{l}\text { Soil fines carried by runoff water from the } \\
\text { Catch Box. No U present as large particles. }\end{array}$ \\
\hline $\begin{array}{l}\text { Ex Gavation samples } \\
\text { Range } 20\end{array}$ & $\begin{array}{l}\text { Buried penetrator rod. Seventy-three to } 75 \% \\
\text { of the uranium, by mass, was found in the } \\
>4.76-m m \text { fraction of the lifts surrounding the } \\
\text { penetrator rod. No uranium was present in } \\
\text { the upper soil levels. }\end{array}$ \\
\hline$\leq 20$ years & $\begin{array}{l}\text { Heavy weathering. Only 17\% of the U, by } \\
\text { mass, was found as large particles. }\end{array}$ \\
\hline
\end{tabular}




\section{Comparison of the Effectiveness of Field Grinding and Laboratory Grinding for the Homogenization and Quantification of Uranium}

Metals in soil are known to be distributed heterogeneously. The extensive mixing of the large soil samples was intended to reduce this heterogeneity (Larson et al. 2007a, 2007b). Two soil grinding procedures were also tested in an attempt to improve the reliability of sample analysis and reduce analytical costs associated with soil remediation. A sample of each test soil was field ground and then returned to the laboratory. At the laboratory, the soil sample was divided in half. One half was digested and analyzed (the field ground sample). The other half was ground a second, finer, time, and then digested and analyzed. A significant cost savings could be realized for in situ remediation of the depleted uranium-contaminated soils if field grinding alone would yield reliable results.

Table 39 shows the effectiveness of this homogenization, sub-sampling, and soil grinding effort in the analysis of the entire $<4$.76-mm size fraction of each of these soils. Several points become clear:

- When comparing the $U$ concentration from the field-ground and the lab-ground samples, there was, more often, a significant decrease or no significant change, than there was a significant increase in concentration. The sample that demonstrated an increase in uranium concentration following the lab grinding was the Retention Pond sediment. The Catch Box 3 sample showed no significant change in concentration. All other samples demonstrated a significant decrease in U concentration after the second, laboratory, grinding.

- The standard deviations between soil replicates of the Catch Box and Range 20 samples are very small, ranging from 0.10 to 0.19 , corresponding to a percent standard deviation of 0.7 to 2.06 percent. The additional grinding effort did not result in greater homogeneity for the sample. This indicates that the particle size distribution achieved by field grinding was small enough that efficient mixing was possible.

- Of the triplicate pairs tested, after laboratory grinding, only the Retention Pond soil showed an increased percent standard deviation (increased homogeneity). No significant change in soil homogeneity occurred in the Range 20 soils. The Catch Box soil and both DU Garden soils showed a decreased percent standard deviation (decreased soil homogeneity). 
Table 39. Comparison of the uranium concentration in the $<4.76-\mathrm{mm}$ soil particle size fraction, determined by either field or laboratory grinding, of the soil sampled from the Catch Box and Range 20.

\begin{tabular}{|c|c|c|c|c|}
\hline \multirow[t]{2}{*}{ YPG site } & \multirow[t]{2}{*}{ Grinding Procedure } & \multicolumn{3}{|c|}{ U Concentration } \\
\hline & & Avg & Stdev & $\%$ Stdev \\
\hline \multirow[t]{2}{*}{ Catch Box 1} & Field grind & $1,201.00$ & 76.18 & $6.34 \%$ \\
\hline & Lab grind & $1,014.50^{\mathrm{D}}$ & 90.27 & $8.90 \%$ \\
\hline \multirow[t]{2}{*}{ Catch Box 2} & Field grind & 1300.00 & 128.04 & $9.85 \%$ \\
\hline & Lab grind & $1,066.33^{\prime}$ & 5.69 & $0.53 \%$ \\
\hline \multirow[t]{2}{*}{ Catch Box 3} & Field grind & 784.87 & 150.90 & $19.23 \%$ \\
\hline & Lab grind & 742.67 NS & 38.13 & $5.13 \%$ \\
\hline \multirow[t]{2}{*}{ Catch Box summary } & Field grind & 1095.29 & 0.19 & $2.06 \%$ \\
\hline & Lab grind & 941.17 & 0.10 & $1.09 \%$ \\
\hline \multirow[t]{2}{*}{ Range 20- 1} & Field grind & $9,320.00$ & 733.31 & $7.87 \%$ \\
\hline & Lab grind & $7,301 . .33^{D}$ & 577.24 & $7.91 \%$ \\
\hline \multirow[t]{2}{*}{ Range $20-2$} & Field grind & $13,026.67$ & 285.89 & $2.19 \%$ \\
\hline & Lab grind & $13,106.67^{D}$ & 23.09 & $0.18 \%$ \\
\hline \multirow[t]{2}{*}{ Range 20- 3} & Field grind & $13,436.67$ & 184.75 & $1.37 \%$ \\
\hline & Lab grind & $12,783.33^{D}$ & 208.17 & $1.63 \%$ \\
\hline \multirow[t]{2}{*}{ Range 20 summary } & Field grind & 11927.78 & 0.07 & $0.07 \%$ \\
\hline & Lab grind & 11063.78 & 0.06 & $0.07 \%$ \\
\hline \multirow{2}{*}{$\begin{array}{l}\text { DU Garden lift } 4 \\
(22.86-30.48 \mathrm{~cm} \text { bgs })\end{array}$} & Field grind & $21,510.00$ & 762.95 & $3.55 \%$ \\
\hline & Lab grind & $20,076.67^{D}$ & 190.88 & $0.95 \%$ \\
\hline \multirow{2}{*}{$\begin{array}{l}\text { DU Garden lift } 5 \\
(30.48-38.10 \mathrm{~cm} \text { bgs })\end{array}$} & Field grind & $35,683.33$ & 732.21 & $2.05 \%$ \\
\hline & Lab grind & $33,290.00^{D}$ & 391.28 & $1.18 \%$ \\
\hline \multirow{2}{*}{ Retention Pond } & Field grind & 904.83 & 9.21 & $1.02 \%$ \\
\hline & Lab grind & $1,160.67^{1}$ & 13.43 & $1.16 \%$ \\
\hline
\end{tabular}

The increase or decrease in the average uranium concentration measured in the digest produced by field and laboratory grinding can be the result of several factors: 
- Smaller particles are more completely digested during the microwave digestion process and, as a result, it is possible to observe increased concentrations of uranium in the more finely ground samples.

- However, the additional sample handling that is required to perform the laboratory grinding provides a means for physical loss of uranium from a sample because uranium can adhere to the surface of the grinding apparatus.

- The agate bowls used in the Fritsch Pulverisette 7 can act as a sink for uranium if static charges or the bowl coating preferentially remove uranium from the bulk sample in a manner that is not uniform with the other soil constituents.

Because laboratory grinding was not effective at reducing the sample heterogeneity beyond the reductions observed in the field-ground samples, and because there was a potential loss of analyte during the second, laboratory, grinding, it was determined that analytical results from the field ground samples were most useful.

\section{Physical Separation Processes}

Two main concerns regarding the use of uranium in Catch Boxes are:

1. Keeping the uranium within the impact area.

2. Ensuring that a situation does not develop where so much metallic uranium is present that a sustained phyrophoric reaction can occur within the impact area.

These two concerns can be addressed by separating and removing particulate uranium from the soil using physical separation processes. Physical separation processes use particle characteristics such as size, shape, density, and/ or magnetism for separating particles. The two physical characteristics most commonly used to separate particles from range soils are particle size (using sieving) and density (using gravity separation). Size separation is a mechanical process in which the soil material is applied to one or more chambers with progressively smaller openings. Material is sorted based on whether it passes through or is retained at each step. Four methods for physically separating DU from the soil were compared in this study: 
1. Dry sieve separation

2. Wet sieve separation

3. Heavy liquid density separation

4. Water/momentum density separation

\section{Dry sieve separation for uranium removal: Comparison of three site soils}

Dry sieving technologies use different size sieves or screens, often in a nested or sequential configuration, to segregate materials according to particle size. Dry sieving is an effective method for separating different sized particle fractions, is relatively efficient and cost-effective, and requires minimal mobilization effort. Conventional dry sieving is effective for a wide range of particle sizes. However, sieve sizes smaller than $4.76 \mathrm{~mm}$ may require very dry soil (depending upon the soil silt and clay content) due to blinding and blockage of the screen. Hard clumps of soil may not break up and thus may be retained intact on the larger screens. Dry sieving does not differentiate between organic, metallic, and geologic materials, and cannot separate bullets and bullet fragments, for example, from soil material of the same size.

The use of simple dry sieving to separate the large particles of DU metal and DU oxides that are the residuals of DU penetrators impacting soils was evaluated for three of the four site soils collected at YPG. The Catch Box soil type represented the type of uranium separation achievable from Catch Box soil if separation was performed periodically. The uranium present in the Catch Box soil was deposited approximately 18 months prior to collection of the large composite sample. The samples obtained from the excavation of an intact penetrator buried in the DU Garden at a depth of $30.48 \mathrm{~cm}$ (12 in.), 5 years prior to sample collection, represented a system in which a penetrator lies undisturbed for an extended period of time in the subsurface. Range 20 has a history of depleted uranium penetrator testing that goes back over 20 years. The large, composite soil sample obtained there reflects the long-term changes that might be found when DU penetrator residues are allowed to weather over extended periods of time. Table 40 presents the mass of uranium measured in each of the four size fractions obtained from the dry sieving techniques as well as the percentage of the total uranium present in each of the size fractions. 
Table 40. Summary of uranium mass in dry sieve size fractions from three YPG sites, and the percentage of total uranium in each fraction.

\begin{tabular}{|c|c|c|c|c|c|c|c|c|}
\hline Soil Size Fraction $(\mathrm{mm})$ & \multicolumn{4}{|c|}{ Mass of U (mg) per Sampling Area } & \multicolumn{4}{|c|}{$\%$ of Total U per Sampling Area } \\
\hline$>4.76 \mathrm{~mm}$ & $1,196.67$ & $9,233.33$ & $430,200.00$ & $710,500.00$ & $11.30 \%$ & $15.84 \%$ & $72.78 \%$ & $75.02 \%$ \\
\hline$<2.00 \mathrm{~mm}$ to $>0.297 \mathrm{~mm}$ & $4,754.65$ & $23,890.97$ & $93,366.00$ & $141,097.01$ & $40.59 \%$ & $41.93 \%$ & $15.79 \%$ & $14.90 \%$ \\
\hline$<0.297 \mathrm{~mm}$ & $1,543.20$ & $7,959.78^{b}$ & $20,547.84$ & $18,502.00$ & $13.70 \%$ & $14.07 \%$ & $3.48 \%$ & $1.95 \%$ \\
\hline Total & $12,135.78$ & $59,022.82$ & $591,135.18$ & $947,099.01$ & & & & \\
\hline $\begin{array}{l}\text { Avg soil mass } \\
\text { (kg) }\end{array}$ & 4.72 & 5.52 & 7.90 & 7.90 & & & & \\
\hline
\end{tabular}


In the Catch Box soil, the majority ( 75 percent) of the uranium was found in the two middle size fractions, the $<4.76 \mathrm{~mm}$ to $2.00 \mathrm{~mm}$ and the $<2.00 \mathrm{~mm}$ to $>0.297 \mathrm{~mm}$. The remaining uranium ( 25 percent) was divided fairly evenly between the largest and the smallest size fractions $(>4.76$ and $<0.297 \mathrm{~mm}$ ). This suggests that a combination of factors within the Catch Box results in the uranium distribution within the various soil size fractions:

- Impacts with the Catch Box sand resulting in abrasion of the penetrator surface and consequent metal deposition.

- Impacts with the Catch Box sand resulting in finer and finer sand particles and loss of stopping power.

- Impacts with other penetrators in the Catch box resulting in fragmentation of the metallic residues.

- Weathering of the penetrator residues.

The gradual increase of the uranium mass in the three larger soil size fractions is a strong indication that dry sieving of this material is going to be useful for the removal of uranium from soil to a level that will be protective of fugitive emissions of uranium as dust and prevent pyrophoric reactions within the Catch Box. The weathering of uranium residues over the relatively short time period involved with the Catch Box was not long enough to significantly degrade the uranium to a point where it could not be separated from individual soil particles.

Dry sieve separation of the Catch Box and Range 20 soils showed very similar distribution of uranium between the different soil size fractions (Table 40). The removal of large fragments of DU (>4.76 mm) was 11 and 16 percent of the total DU mass, in the Catch Box and Range 20 soils, respectively. The bulk of the mass of DU was found in the middle particle size ranges for both sites, 75 and 70 percent of the total mass of DU in the Catch Box and the Range 20 soils, respectively.

Three small-caliber DU penetrators were present in the sub-samples from the large, composite sample obtained from Range 20. These items were essentially intact with little evidence of corrosion. The penetrators represented a significant mass of DU but they appeared to either be recently deposited or had remained on the surface of the soil since their deposition. DU metal that is present on the soil surface has been noted to undergo minimal oxidation to form the uranium oxides over time. In the DU Gar- 
den, the two sets of penetrators that were placed directly on the soil surface showed significantly less degradation compared to those that were buried in the subsurface. (Buck et al. 2004).

The two uranium-laden samples obtained from the excavation of the intact penetrator buried for five years at a depth of $30.5 \mathrm{~cm}$ (12 in.) in the DU Garden provided an example of penetrators that end up buried in the shallow subsurface and remain undisturbed by subsequent range use or erosion. These conditions are important as this type of DU residue is one that can be detected readily using state-of-the-art DU location tools (Etheridge et al. 2008). Once located, the excavation of these residues may be useful for long-term range management activities in order to reduce the spatial distribution of uranium on the range. As the excavation proceeded, 7.6- $\mathrm{cm}$ (3-in.) soil lifts were removed from the region above the penetrator. The first three soil lifts were free of uranium above the background levels for the site. The remaining two lifts, DU Garden lift 4 and DU Garden lift 5, were processed by dry sieving. The overall concentration and distribution of uranium in these two fractions was significantly different than those noted in the Catch Box and Range 20 soils. Greater than 70 percent of the total uranium was found in the $>4.76 \mathrm{~mm}$ ( \#4 sieve) size fraction of both lift 4 and lift 5 . The $<2.00$ to $>0.297-\mathrm{mm}$ soil size fraction contained most of the remaining DU in both lifts (16-15 percent). Less than 5 percent of the uranium was found in the finest fraction $(<0.297-\mathrm{mm})$ for either lift. When compared to the samples taken from Range 20, this particle size distribution was much more amenable to a gross sieving separation. This is thought to occur because the area was undisturbed over the 5 years that the penetrator remained buried.

Range management of Catch Box areas could be accomplished with simple dry sieve separation using the four sieve sizes employed in this study. The largest and the smallest fractions could be combined and returned to the Catch Box as a relatively uranium-free impact medium and supplemented with additional clean sand.

Range management of buried penetrators, once located and excavated, would require only a single dry sieve separation. Using the 4.76- $\mathrm{mm}$ sieve, the soil could be separated into two fractions, $>4.76 \mathrm{~mm}$ and $<4.76 \mathrm{~mm}$. The $>4.76-\mathrm{mm}$ fraction containing $>70$ percent of the uranium could be stored and disposed of with the other high uranium content materials col- 
lected from the range during normal range management operations. This would leave a largely uranium-free soil to be returned to the range.

\section{Wet sieve separation for uranium removal: Comparison of four site soils}

Wet sieving uses water to slurry, de-agglomerate the soil, and aid the passage of the material through screens, often in a nested or sequential configuration, for separation according to particle size. Similar to the dry process, wet sieving alone does not differentiate between organic, metallic, and geologic materials, and cannot separate bullets and bullet fragments from soil material of the same size.

In order to further evaluate the effectiveness of separation of uranium from soils impacted by DU penetrators, smaller sub-samples of the eight $25-\mathrm{Kg}$ sub-samples were obtained and water was used to pass the soil through a series of sieves. This procedure was performed by hand and it can lead to a more complete disaggregation of particles as a result of the effect of water in separating soil and DU residue agglomerates. Table 41 compares the distribution of uranium in the four soil particle size fractions achieved by wet sieving soil from the Catch Box, Range 20, and the DU Garden, lifts 4 and 5.

The uranium distribution in soil size fractions achieved by wet sieve separation of the Catch Box and Range 20 soils was very similar. Compared to the dry sieve separation results for the same soil size fractions, there was a shift in the particle size distribution of the uranium to the smaller particle size fractions when water was introduced into the separation process (Table 42). A similar and even more striking shift in the uranium distribution when wet sieving was compared to dry sieving was observed for the two samples obtained from the DU Garden (Table 42). The 22.86- to 30.48-cm (9- to 12-in.) and the 30.48- to 38.10-cm (12- to 15-in.) soil lifts showed 74 and 84 percent uranium in the smallest size fraction during wet sieving compared to 73 and 75 percent in the largest size fraction during dry sieving. 
Table 41. Distribution of uranium according to soil particle size achieved by wet sieve separation of Catch Box, Range 20 , and DU Garden soil samples.

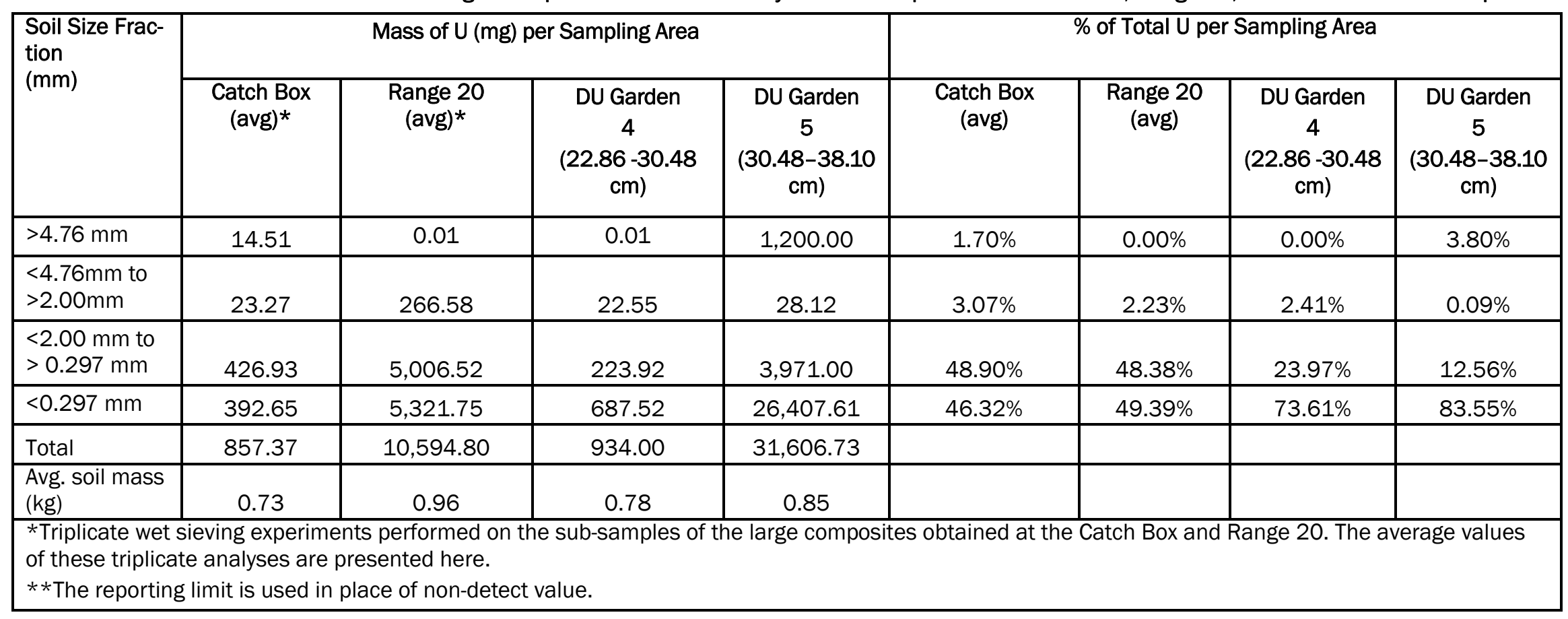


Table 42. Comparison of uranium distribution in soil size fractions produced by dry and wet sieve separation.

\begin{tabular}{|c|c|c|c|c|c|c|c|c|}
\hline \multirow{2}{*}{$\begin{array}{l}\text { Soil Size Frac- } \\
\text { tion } \\
(\mathrm{mm})\end{array}$} & \multicolumn{4}{|c|}{$\begin{array}{c}\text { Dry Sieve Separation } \\
\% \text { of Total U per Sampling Area }\end{array}$} & \multicolumn{4}{|c|}{$\begin{array}{c}\text { Wet Sieve Separation } \\
\% \text { of Total U per Sampling Area }\end{array}$} \\
\hline & $\begin{array}{l}\text { Catch Box } \\
\text { (avg)* }\end{array}$ & $\begin{array}{l}\text { Range } 20 \\
\text { (avg)* }\end{array}$ & $\begin{array}{c}\text { DU Garden } \\
4 \\
(22.86-30.48 \\
\mathrm{cm})\end{array}$ & $\begin{array}{c}\text { DU Garden } \\
5 \\
(30.48-38.10 \\
\mathrm{cm})\end{array}$ & $\begin{array}{l}\text { Catch Box } \\
\text { (avg) }\end{array}$ & $\begin{array}{l}\text { Range } 20 \\
\text { (avg) }\end{array}$ & $\begin{array}{c}\text { DU Garden } \\
4 \\
(22.86-30.48 \\
\mathrm{cm})\end{array}$ & $\begin{array}{c}\text { DU Garden } \\
5 \\
(30.48-38.10 \\
\mathrm{cm})\end{array}$ \\
\hline$>4.76 \mathrm{~mm}$ & $11.30 \%$ & $15.84 \%$ & $72.78 \%$ & $75.02 \%$ & $1.70 \%$ & $0.00 \%$ & $0.00 \%$ & $3.80 \%$ \\
\hline $\begin{array}{l}<4.76 \mathrm{~mm} \text { to } \\
>2.00 \mathrm{~mm}\end{array}$ & $34.41 \%$ & $28.16 \%$ & $7.95 \%$ & $8.13 \%$ & $3.07 \%$ & $2.23 \%$ & $2.41 \%$ & $0.09 \%$ \\
\hline $\begin{array}{l}<2.00 \mathrm{~mm} \text { to } \\
>0.297 \mathrm{~mm}\end{array}$ & $40.59 \%$ & $41.93 \%$ & $15.79 \%$ & $14.90 \%$ & $48.90 \%$ & $48.38 \%$ & $23.97 \%$ & $12.56 \%$ \\
\hline$<0.297 \mathrm{~mm}$ & $13.70 \%$ & $14.07 \%$ & $3.48 \%$ & $1.95 \%$ & $46.32 \%$ & $49.39 \%$ & $73.61 \%$ & $83.55 \%$ \\
\hline
\end{tabular}


The uranium distribution shift to smaller soil size fractions shift is thought to be due to a combination of:

- Small particles with substantial uranium content becoming disaggregated by water from the larger soil particles and passing through the larger sieve sizes.

The uranium oxide minerals breaking apart into smaller individual uranium oxide particles when subjected to the wet sieving process.

The Retention Pond sample consisted of fine-grained sediments that had been transported from the Catch Box. Because it had a smaller particle size distribution than the three surface soil samples discussed above, a different set of sieves with finer particle sizes were used to wet sieve the Retention Pond soil. As seen in Table 21 of the Results, 97 percent of the uranium was observed to be associated with the smallest, $<0.037-\mathrm{mm}$ size fraction following wet sieving of this soil. This is an indication that the uranium present in this sample is primarily present in the form of uranium ions sorbed to individual, fine soil particles. This is expected, as the process for sediment entering the retention pond is surface flow carrying suspended solids and dissolved uranium into the lined pond. The water stays in the retention pond, evaporation occurs, and the sediment dries to form a cake on the bottom of the pond. During this period of prolonged saturation it is expected that any uranium oxides present will form soluble uranium salts that dissolve in the standing water. These ions are then sorbed onto the high surface area, charged soil surfaces. The result is a soil material in which the uranium is highly associated with the soil itself and separation by any technique other than chemical washing of the soil will be difficult. Also, as noted in the Results section, wet sieving of all of these soil samples produced a waste stream of separation water contaminated by the soluble uranium decomposition products.

To achieve the goal of reducing the total uranium concentration within the box and removing the larger, metallic residues of DU penetrators, a simple dry sieve separation of the soil, without the use of water, is indicated.

\section{Heavy liquid density separation for uranium removal: Comparison of four site soils}

Gravity separation technologies separate particles based on differential settling (related to particle size, shape and/ or density) through water, or 
another liquid medium. Each separated fraction consists of various size particles that fall into a similar range of density. These technologies can be very effective for separating organic, metallic, and geologic particles of the same or similar size that have different densities (Larson et al. 2007b). This approach was considered for the YPG site because of the high density of both the uranium metal and the uranium oxides and salts. These latter are produced as the uranium weathers and are evident as black and yellow coatings on the solid surface (Mellini and Riccobono 2005; Figure 1). The specific gravity of uranium is $18.95 \mathrm{~g} / \mathrm{cm}^{3}$, uranium oxide is $10.96 \mathrm{~g} / \mathrm{cm}^{3}$, and that of rock/ soil/sand varies, but can be approximated at $2.5 \mathrm{~g} / \mathrm{cm}^{3}$. This difference in density is what makes gravimetric separation of these corrosion products of DU residues from soil possible. However, the uranium oxides have significant solubility in water and the resulting ionic uranium can form uranium-based salts with lower densities as well as sorb to clays and organic matter in soil and form complexes with soil particles (J ohnson et al. 2004, Choy et al. 2006, Dong et al. 2006).

In order to evaluate the separation of uranium from the four site soils studied at YPG, a series of heavy liquid density separations were performed using a polytungstate solution with a density of $2.85 \mathrm{~g} / \mathrm{cm}^{3}$. This liquid is dense enough to suspend most soil particles, including stones, in the solution, leaving a bottom layer of solids with densities significantly greater than that of the heavy liquid. An additional fraction is suspended in the heavy liquid and is most often considered part of the floating fraction.

In the mining industry it is usually the heavy fraction of a mineral suite that contains the valuable component, which is separated from sand (silica) and other components having a density less than $2.5 \mathrm{~g} / \mathrm{cm}^{3}$. The solution density used for this type of separation is $2.85 \mathrm{~g} / \mathrm{cm}^{3}$, nearly three times the density of water. Two isopolytungstate compounds have been available for some time, and are known as sodium metatungstate or sodium polytungstate (SPT) and lithium metatungstate (LMT). The tungsten anion for SPT and LMT is $\left[\mathrm{H}_{2} \mathrm{~W}_{12} \mathrm{O}_{40}\right]^{6-}$. These compounds belong to a class of structures known in the literature as the "Keggin" species. Both SPT and LMT are relatively non-toxic and generally inert. SPT has a viscosity of over $20 \mathrm{cP}$ at a density of $2.85 \mathrm{~g} / \mathrm{mL}$. While this makes a gravity separation technique potentially very effective for the removal of uranium from soil, the expense of SPT makes it impractical for field-scale separations. 
Table 43 compares the distribution of uranium in the three fractions produced by heavy liquid density separation of the Catch Box, Range 20, DU Garden, and Retention Pond soils. Three of the five soil samples showed distinct separation of the uranium into the bottom fraction. The Catch Box, Range 20, and DU Garden lift 5 samples all left 84 percent or more of the total uranium present in the separated samples at the bottom of the separation vessel.

The Retention Pond and the DU Garden lift 4 soils had all of the uranium in the floating/ suspended fractions. No uranium was found in the bottom fraction. This indicates that most of the uranium in these samples has gone through the entire process of oxidation, dissolution, and sorption onto soil particles. The density of a soil particle containing sorbed uranium is not considerably different from that of clean soil particles. As a result, uranium that has become an ionic sorbed species on these particles will be found in the light fraction with the rest of the soil. As lift 4 is made of soil directly overlying the buried penetrator, the implication is that the oxidation products migrated upwards through the soil.

The implication is that if DU penetrator residues are allowed to weather in the environment, over time the particle size of the uranium metal and its oxidation products will continue to decrease. Once the particle sizes are reduced to the point that the uranium distribution closely matches the soil particle size distribution (i.e., uranium oxides and salts have chemically interacted with soil constituents), physical separation becomes less useful for removal. This leaves technologies that chemically strip the contaminant from the soil and produce a liquid waste that contains the contaminant. Also, there is an increased likelihood that the uranium found in the finer soil fractions can be mobilized in the environment during surface water flow events or transported as dust particles in the air. 
Table 43. Distribution of uranium according to soil particle density achieved by heavy liquid density separation of Catch Box, Range 20, DU Garden and Retention Pond soils.

\begin{tabular}{|c|c|c|c|c|c|c|c|c|c|c|}
\hline \multirow{2}{*}{$\begin{array}{l}\text { Soil Size } \\
\text { Fraction }\end{array}$} & \multicolumn{5}{|c|}{ Mass of $U$ (mg) per Sampling Area } & \multicolumn{5}{|c|}{$\%$ of Total U per Sampling Area } \\
\hline & $\begin{array}{l}\text { Catch Box } \\
\text { (avg) }{ }^{1}\end{array}$ & $\begin{array}{l}\text { Range 20 } \\
\text { (avg) }^{1}\end{array}$ & $\begin{array}{l}\text { DU Garden } \\
4\end{array}$ & $\begin{array}{l}\text { DU Garden } \\
5\end{array}$ & $\begin{array}{l}\text { Retention } \\
\text { Pond }\end{array}$ & $\begin{array}{l}\text { Catch Box } \\
\text { (avg)* }\end{array}$ & $\begin{array}{l}\text { Range } 20 \\
\text { (avg)* }\end{array}$ & $\begin{array}{c}\text { DU Garden } \\
4\end{array}$ & \begin{tabular}{|c} 
DU Garden \\
5
\end{tabular} & $\begin{array}{l}\text { Retention } \\
\text { Pond }\end{array}$ \\
\hline Bottom & 191.67 & $1,017.03$ & 0.00 & $3,123.83$ & 0.00 & $84.16 \%$ & $83.83 \%$ & $0.00 \%$ & $93.02 \%$ & $0.00 \%$ \\
\hline Floating & 9.31 & 53.15 & 15.57 & 30.69 & 14.25 & $5.14 \%$ & $4.66 \%$ & $24.53 \%$ & $0.91 \%$ & $36.91 \%$ \\
\hline Suspended & 23.73 & 130.25 & 47.91 & 203.64 & 24.36 & $10.71 \%$ & $11.51 \%$ & $75.47 \%$ & $6.06 \%$ & $63.09 \%$ \\
\hline \multicolumn{11}{|c|}{$\begin{array}{l}{ }^{1} \text { Triplicate wet sieving experiments performed on the sub-samples of the large composites obtained at the Catch Box and Range } 20 \text {. Average values of } \\
\text { these triplicate analyses are presented here. } \\
{ }^{2} \text { Non-detect value, below the reporting limit }\end{array}$} \\
\hline
\end{tabular}




\section{Water/momentum density separation for uranium removal: Comparison of three site soils}

The complicating factor in water/momentum density separation that is not present in a heavy liquid density separation is the dependence of the separation on the particle size range being separated. When a heavy liquid is used, the particles will float or sink in the liquid regardless of the particle size, as particle density is the primary determiner of motion in the heavy liquid. When a low-density liquid such as water is used, the process must add some type of motion to the system like that obtained with a vibrating table. In motion, different particle sizes will have different migration rates along the table even if they have the same density. Tables 44 and 45 summarize the mass of uranium present in Catch Box, Range 20, and DU Garden lift 5 (30.48- to 38.10-cm bgs) soils as determined by Wilfley Table separation of the soil in two size ranges, $0.841 \mathrm{~mm}$ to $0.297 \mathrm{~mm}$ and $<0.297 \mathrm{~mm}$, respectively.

Table 44. Distribution of uranium according to soil particle size and density achieved by Wilfley Table water/momentum separation of Catch Box, Range 20, and DU Garden soils in the $0.841-\mathrm{mm}$ to $0.297-\mathrm{mm}$ size range.

\begin{tabular}{|c|c|c|c|c|c|c|}
\hline \multirow{2}{*}{$\begin{array}{c}\text { Soil } \\
\text { Fraction }\end{array}$} & \multicolumn{3}{|c|}{ Mass of $U(\mathrm{mg})$ per Sampling Area } & \multicolumn{3}{|c|}{$\%$ of Total U per Sampling Area } \\
\hline & $\begin{array}{l}\text { Catch } \\
\text { Box }^{1}\end{array}$ & Range $20^{1}$ & $\begin{array}{c}\text { DU Garden Lift } 5 \\
(30.48-38.10 \mathrm{~cm} \\
\text { bgs })\end{array}$ & $\begin{array}{c}\text { Catch } \\
\text { Box }^{1}\end{array}$ & $\begin{array}{c}\text { Range } \\
20^{1}\end{array}$ & $\begin{array}{l}\text { DU Garden } \\
\text { Lift } 5 \\
(30.48- \\
38.10 \mathrm{~cm} \\
\text { bgs) }\end{array}$ \\
\hline 1 & 3.25 & 5.72 & 588.42 & 1.20 & 0.25 & 3.75 \\
\hline 2 & 4.04 & 13.56 & 708.90 & 1.49 & 0.60 & 4.52 \\
\hline 3 & 4.02 & 20.89 & $1,243.34$ & 1.49 & 0.92 & 7.93 \\
\hline 4 & 2.44 & 55.26 & 939.09 & 0.90 & 2.43 & 5.99 \\
\hline 5 & 164.55 & $1,848.00$ & $9,073.50$ & 60.84 & 81.23 & 57.88 \\
\hline 6 & 92.15 & 331.61 & $3,076.80$ & 34.07 & 14.58 & 19.63 \\
\hline 7 & ns & ns & 46.30 & na & na & 0.30 \\
\hline Total & 270.45 & $2,275.04$ & $15,676.35$ & & & \\
\hline $\begin{array}{l}\text { Total soil } \\
\text { mass (kg) }\end{array}$ & 0.22 & 0.19 & 0.39 & & & \\
\hline \multicolumn{7}{|c|}{$\begin{array}{l}{ }^{1} \text { Triplicate experiments were performed on the sub-samples of the large soil composites ob- } \\
\text { tained from the Catch Box and Range } 20 \text { sites. The average of the triplicate analyses are pre- } \\
\text { sented here. } \\
\text { ns=no sample } \\
\text { na=not applicable }\end{array}$} \\
\hline
\end{tabular}


All three of the site soils showed a large proportion of the total uranium in the fractions that migrated the furthest distance down the Wilfley Table. Fractions 5 and 6 contained 95, 96, and 78 percent of the total uranium present in the Catch Box, Range 20, and the DU Garden lift 5 soils, respectively, in the soil size range between $0.841 \mathrm{~mm}$ and $0.297 \mathrm{~mm}$.

The same separation procedure was performed on the $<0.297-\mathrm{mm}$ size fraction of the soil samples from the Catch Box, Range 20, and DU Garden lift 5. The masses of uranium present in each of the collected fractions from the Wilfley Table, along with the percentage of uranium in each of the density fractions for this finest size fraction, are shown in Table 45.

Table 45. Distribution of uranium according to soil particle size and density achieved by Wilfley Table water/momentum separation of Catch Box, Range 20, and DU Garden soils in the $<0.297-\mathrm{mm}$ size range.

\begin{tabular}{|c|c|c|c|c|c|c|}
\hline \multirow{2}{*}{$\begin{array}{l}\text { Soil Size } \\
\text { Fraction }\end{array}$} & \multicolumn{3}{|c|}{ Mass of $U$ (mg) per Sampling Area } & \multicolumn{3}{|c|}{$\%$ of Total U per Sampling Area } \\
\hline & Catch Box ${ }^{1}$ & Range $20^{1}$ & $\begin{array}{c}\text { DU Garden } \\
5\end{array}$ & Catch Box ${ }^{1}$ & Range $20^{1}$ & $\begin{array}{c}\text { DU Garden } \\
5\end{array}$ \\
\hline 1 & 30.99 & 73.15 & 72.00 & 7.04 & 2.75 & 1.57 \\
\hline 2 & 33.23 & 42.46 & 693.36 & 7.54 & 1.59 & 15.12 \\
\hline 3 & 65.61 & 231.55 & 481.51 & 14.90 & 8.69 & 10.50 \\
\hline 4 & 14.73 & 97.56 & 250.08 & 3.34 & 3.66 & 5.45 \\
\hline 5 & 256.97 & $1,678.80$ & $1,631.67$ & 58.35 & 66.39 & 35.59 \\
\hline 6 & 38.89 & 450.68 & $1,455.60$ & 8.83 & 16.92 & 31.78 \\
\hline 7 & Ns & ns & 0.57 & na & na & 0.01 \\
\hline Total & 440.40 & $2,664.21$ & $4,584.78$ & & & \\
\hline $\begin{array}{l}\text { Total soil } \\
\text { mass (kg) }\end{array}$ & 0.21 & 0.22 & 0.25 & & & \\
\hline \multicolumn{7}{|c|}{$\begin{array}{l}{ }^{1} \text { Triplicate experiments were performed on the sub-samples of the large soil composites ob- } \\
\text { tained from the Catch Box and Range } 20 \text { sites. The average of the triplicate analyses are pre- } \\
\text { sented here. } \\
\text { ns=no sample } \\
\text { na=not applicable }\end{array}$} \\
\hline
\end{tabular}

For this finest size fraction, water/ momentum density separation was not as successful as observed for the $0.841-\mathrm{mm}$ to $0.297-\mathrm{mm}$ size fraction at moving the uranium from the Catch Box soil to the larger density fractions. Following the trend presented by the larger soil particle size, all three of the site soils showed a large proportion of the total uranium in the 
fractions that migrated the furthest distance down the Wilfley Table. However, in this smaller particle size, fractions 5 and 6 contained only 67, 83, and 67 percent of the total uranium present in the Catch Box, Range 20, and DU Garden lift 5 soils, respectively.

Because water is used to effect the separation, together with the vibration of the table, the concentration of uranium in the process water is important, just as it is in wet sieving. The separation water represents a potential waste stream that would be generated if such a density/momentum separation technique were used. The concentrations of uranium measured in the separation waters ranged from $7 \mathrm{mg} / \mathrm{L}$ to $398 \mathrm{mg} / \mathrm{L}$. These high uranium values in water after a relatively short exposure time ( $<30 \mathrm{~min}$ ) are a further indication of the water solubility of some of the uranium oxides and salts that are present in soils where DU penetrator residues undergo weathering.

\section{Soil Profile of Depleted Uranium}

Results of the DU Garden soil core analysis suggested that uranium actually migrated upwards. This observation is counter to most subsurface migration patterns in temperate climates, in which contaminants migrate downward, but is relatively common in arid environments. Depleted uranium metal must corrode for any migration to occur (Baltz 2000). The observation that the corrosion products expand in volume is supported in the literature (Baltz 2000). This vertical migration may be largely caused by this expansion. In previous excavations of these rods, it has been common to find the bulk of the corrosion on the upper surface of the rod, presumably because this portion is preferentially wet by water seepage. Wicking and upward capillary movement, both of which are common in desert environments, may also play a role in this upward migration pattern. Still, the highest concentration of DU was in the zone where the penetrator was buried. And, not surprisingly, the highest concentrations of various decomposition products of DU (the uranium oxides and salts) were found in this area as well.

Studies by J ohnson et al. (2003, 2004) on surface-deposited (air to surface cannon fire) penetrators in an arid environment found downward DU movement on the order of $8 \mathrm{~cm}$. However, as depth increased, the DU reacted to form relatively insoluble silicate minerals, thereby limiting further migration. The DU Garden differs from these studies in that the rod was already buried at $30.5 \mathrm{~cm}$ (12 in.). Presumably, the corrosion products 
were less exposed to surface precipitation, resulting in less downward movement. Interactions between uranium corrosion products and soil mineral and organic components can also affect uranium mobility (Bednar et al. 2007). However, the desert soils used in this study appear to have minimal organic content and, therefore, have little effect on migration.

\section{Comparison of DU forms from Various YPG Sites}

The DU Garden data from sequential extraction analysis presented in Figure 16 suggests that DU favors association with carbonate minerals and with $\mathrm{Fe}-\mathrm{Mn}$ oxides. However, the results of the surface-collected Range 20 samples only had a single Fe-Mn spike and the DU Garden samples were collected from $12 \mathrm{in}$. bgs. Therefore, this pattern may simply be a factor of weathering. The carbonate forms, which are more soluble, may have been solubilized from the Range 20 samples (J ohnson et al. 2003, 2004). Soil types (soil geomorphology) may also play a factor (Buck et al. 2004). Clay content and mineralogy appear to affect the uranium associations formed. This may be key data to collect in future studies of this kind. 


\section{Conclusions and Recommendations}

Physical separation processes performed in the field using heavily weathered range soils showed that DU and U-oxides, which have a much higher density than most soil constituents, can be concentrated and separated from some range soils by both wet and dry separation techniques.

Density separation is only possible for uranium that is present as metallic uranium or as crystalline uranium oxides. Once the uranium oxides have weathered to the point where uranyl ions have formed, these ions are not amenable to separation by simple density-based techniques. The Range 20 soil of YPG provided an extremely weathered sample, hence the significant concentrations of uranium in the low-density soil particles. As the uranium weathers (oxidizes) and forms uranium salts of varying solubility, uranyl ions in solution can associate with ion binding sites on both mineral and organic soil components. When the uranium becomes an integral part of the soil in this manner, the options for removal of the uranium from the soil are reduced to chemical processes.

\section{Recommendations Specific to Yuma Proving Ground}

Range management of Catch Box areas could be accomplished with simple dry sieve separation using the four sieve sizes employed in this study. The largest and the smallest fractions could be combined and returned to the Catch Box as a relatively uranium-free impact medium and supplemented with additional clean sand.

Range management of buried penetrators, once located and excavated, would require only a single dry sieve separation. Using the $4.76-\mathrm{mm}$ sieve, the soil could be separated into two fractions, $>4.76 \mathrm{~mm}$ and $<4.76 \mathrm{~mm}$. The $>4$.76-mm fraction, containing $>70$ percent of the uranium, could be stored and disposed of with the other high uranium content materials collected from the range during normal range management operations. This would leave a largely uranium-free soil, the $<4$. 76 - $\mathrm{mm}$ fraction, to be returned to the range. 


\section{General Recommendations}

Several general recommendations result from this study. Observations made during the field study suggested that metallic fragments of DU can be easily removed from sand by size separation. Size separation is possible because most DU fragments are larger than the sand particles, and is particularly attractive as it can be easily applied using simple vibratory or agitated screening techniques. Size separation of DU metallic fragments can be easily and inexpensively accomplished and is expected to be applicable to full-scale DU metallic fragment separation operations. Periodically removing these fragments would decrease the rate of release of $U$ to the sand bed, prolonging its life.

It is recommended that an additional field study be conducted focusing strictly on the use of size separation to remove metallic DU fragments. The study would evaluate the effectiveness and costs associated with size separation using actual Catch Box sand with treatment masses on the scale of $1000 \mathrm{~kg}$. Effectiveness under different conditions, such as moisture content of the impact area, can be tested. The study could be designed to provide the data required for a pilot or full-scale demonstration, such as an ESTCP (Environmental Security Testing and Certification Program) project.

This investigation, as well as general observations at facilities like YPG, and scientific journal articles, indicates that DU metals are readily corroded (J ohnson et al. 2004). The oxidation products are more mobile than the metal parent and can be transformed in the environment. The corrosion of the uranium metal should be studied, including the role of microbial processes. If the corrosion process can be retarded, then the mechanism for transport of uranium metal will be limited to that of physical movement of metal fragments. Because the density of DU metal is extremely high, movement would be minimal.

The studies presented in this report suggest that DU can become associated with sand particles, be it by impact smearing or by corrosion and chemical interaction. Sensor studies, which are covered in a separate report, indicate that DU-contaminated sand is deposited around the Catch Box, presumably by airborne processes. Studies should also be conducted to understand the airborne movement of DU-contaminated sand from the Catch Box. Two processes are critical - ejected sand from projectile impact 
and wind-eroded materials. Studies should be designed to investigate these processes. 


\section{References}

Baltz, J . 2000. The corrosion and chemical speciation of depleted uranium munitions at the U.S. Army Yuma Proving Grounds. MS thesis, Civil Engineering, The University of New Mexico, Albuquerque, NM.

Bednar, A., V. F. Medina, D. Ulmer-Scholle, B. Frey, W. Brostoff, B. L. J ohnson, and S. L. Larson. 2007. Effects of organic matter on the speciation of uranium in soil and plant matrices. Chemosphere 70:237-247.

Betti, M. 2003. Civil use of depleted uranium. J ournal of Environmental Radioactivity 64:113-119.

Bleise, A., P. R. Danesi, and W. Burkart. 2003. Properties, use and health effects of depleted uranium (DU): A general overview. J ournal of Environmental Radioactivity 64:93-112.

Buck, B. J ., A. L. Brock, W. H. J ohnson, and A. L. Ulery. 2004. Corrosion of depleted uranium in an arid environment: Soil-geomorphology, SEM/EDS, XRD, and electron microprobe analyses. Soil and Sediment Contamination 13:545-561.

Burkart, W., P. R. Danesi, and J . H. Hendry. 2005. Properties, use and health effects of depleted uranium. International Congress Series 1276:133-136.

Choy, C. C., G. P. Korfiatis, and X. Meng. 2006. Removal of depleted uranium from contaminated soils. J ournal of Hazardous Materials 136:53-60.

Dong, W., G. Xie, T. R. Miller, M. P. Franklin, T. P. Oxenberg, E. J . Bouwer, W. P. Ball, and R.U. Halden. 2006. Sorption and bioreduction of hexavalent uranium at a military facility by the Chesapeake Bay. Environmental Pollution 142:132-142.

Etheridge, J . A., P.-R. J ang, D. L. Monts, D. M. Rogers, C. A. Sparrow, Y. Su, and C. A. Waggoner. 2009. Locating expended depleted uranium munitions. DOD/ USAERDC Contract No. W912HZ-06-C-0032. Starkville, MS: Institute for Clean Energy Technology, Bagley College of Engineering, Mississippi State University.

Giannardi, C., and D. Domenici. 2003. Military use of depleted uranium: Assessment of prolonged population exposure. J ournal of Environmental Radioactivity 64:227-236.

Hamilton, E. I. 2001. Depleted uranium (DU): A holistic consideration of DU and related matters. The Science of the Total Environment 281:5-21.

J ohnson, W. H., B. Buck, H. Brogonia, and A. L. Brock. 2003. Presentation slides, Depleted Uranium Management Project Program Review. Santa Fe, NM: New Mexico State University. 
J ohnson, W. H., B. Buck, H. Brogonia, and A. L. Brock. 2004. Variations in depleted uranium sorption and solubility with depth in arid soils. Soil and Sediment Contamination 13:533-544.

Larson, S. L., P. G. Malone, C. A. Weiss, W. A. Martin, C. Trest, G. Fabian, M. F. Warminsky, D. Mackie, J . J . Tasca, J . Wildey, and J . Wright. 2007a. Amended ballistic sand studies to provide low maintenance lead containment at active small arms firing range systems. ERDC TR-07-14. Vicksburg, MS: U.S. Army Engineer Research and Development Center.

Larson, S. L., C. L. Teeter, V. F. Medina, and W. A. Martin. 2007b. Treatment and management of closed or inactive small arms firing ranges. ERDC/ EL TR-07-6. Vicksburg, MS: U.S. Army Engineer Research and Development Center.

McLaughlin, J . P. 2005. Public health and environmental aspects of DU. International Congress Series 1276:137-140.

Meinrath, A., P. Schneider, and G. Meinrath. 2003. Uranium ores and depleted uranium in the environment, with a reference to uranium in the biosphere from the Erzgebirge/ Sachsen, Germany. J ournal of Environmental Radioactivity 64:175193.

Mellini, M., and F. Riccobono. 2005. Chemical and mineralogical transformations caused by weathering in anti-tank DU penetrators ("the silver bullets") discharged during the Kosovo war. Chemosphere 60:1246-1252.

Ryan, J . A., P. Zhang, D. Hesterbert, J . Chou, and D. E. Sayers. 2001. Formation of chloropyromorphite in a lead-contaminated soil amended with hydroxyapatite. ES\&T 35:3798-3803.

Taggart, A. F. 1945. Handbook of mineral dressing, ores and industrial minerals. New York: J. Wiley.

Tessier, A., P. G. C. Campbell, and M. Bisson. 1979. Sequential extraction procedure for the speciation of particulate trace metals. Anal. Chem. 51:844-851.

Tessier, A., P. G. C. Campbell, and M. Bisson. 1988. Partitioning of trace metals in sediments. In Metal speciation: Theory, analysis and application, ed. J.K. Kramer and H.E. Allen. 183-199. Chelsea, MI: Lewis Publisher.

U.S. Environmental Protection Agency (USEPA). 1999. Test methods for evaluating solid waste, physical/ chemical methods. SW-846. Washington, DC. 


\section{Appendix A. Initial Grind}


Table A1. Background 1 Initial Grind

\begin{tabular}{|c|c|c|c|c|c|c|c|c|c|c|c|c|c|c|}
\hline \multirow[t]{2}{*}{ Separation procedure } & \multicolumn{14}{|c|}{$\begin{array}{l}\text { Metals } \\
(\mathrm{mg} / \mathrm{kg})\end{array}$} \\
\hline & $\mathrm{Pb}$ & $\mathrm{Cr}$ & $\mathrm{Cu}$ & $\mathrm{Ni}$ & $Z n$ & $\mathrm{Fe}$ & $\mathrm{Mn}$ & Mo & $\mathrm{V}$ & $\mathrm{Sb}$ & W & As & $\mathrm{Ca}$ & $u$ \\
\hline IG_<4.76 mm_BGGEL_1 (no grind) rep. 1 & $<5^{\star}$ & $<5$ & $<5$ & $<5$ & 19.25 & 4350.00 & 214.80 & $<5$ & $<5$ & $<5$ & $<5$ & $<5$ & NS & $<5$ \\
\hline IG_<4.76 mm_BGGEL_1 (no grind) rep. 2 & $<5$ & $<5$ & $<5$ & $<5$ & 19.64 & 5010.00 & 223.20 & $<5$ & $<5$ & $<5$ & $<5$ & $<5$ & NS & 11.08 \\
\hline IG_<4.76 mm_BGGEL_1 (no grind) rep. 3 & $<5$ & $<5$ & $<5$ & 11.02 & 26.85 & 7436.00 & 248.40 & $<5$ & 10.11 & $<5$ & $<5$ & $<5$ & NS & 21.17 \\
\hline Average & $* *$ & $* *$ & $* *$ & 11.02 & 21.91 & 5598.67 & 228.80 & ** & 10.11 & ** & $* *$ & ** & & 16.13 \\
\hline IG_<4.76 mm_BGGEL_1(ground) rep. 1 & $<5$ & $<5$ & $<5$ & 10.38 & 25.71 & 7328.00 & 223.80 & $<5$ & 14.05 & $<5$ & $<5$ & $<5$ & NS & $<5$ \\
\hline IG_<4.76 mm_BGGEL_1 (ground) rep. 2 & $<5$ & $<5$ & $<5$ & 5.00 & 24.29 & 6755.00 & 215.90 & $<5$ & 12.85 & $<5$ & $<5$ & $<5$ & NS & 11.08 \\
\hline IG_<4.76 mm_BGGEL_1(ground) rep. 3 & $<5$ & $<5$ & $<5$ & 5.00 & 24.23 & 6685.00 & 213.50 & $<5$ & 12.79 & $<5$ & $<5$ & $<5$ & NS & 21.17 \\
\hline Average & $* *$ & $* *$ & $* *$ & 6.79 & 24.74 & \begin{tabular}{|l}
6922.67 \\
\end{tabular} & 217.73 & $* *$ & 13.23 & $* *$ & $* *$ & $* *$ & & 16.13 \\
\hline St dev & $* *$ & $* *$ & $* *$ & 3.11 & 0.84 & 352.77 & 5.39 & $* *$ & 0.71 & $* *$ & $* *$ & $* *$ & & 7.13 \\
\hline
\end{tabular}


Table A2. Background 2 Initial Grind

\begin{tabular}{|c|c|c|c|c|c|c|c|c|c|c|c|c|c|c|}
\hline Separation Procedure & \multicolumn{14}{|c|}{ Metals (mg/kg) } \\
\hline IG_<4.76 mm_BGGEL_3(no grind) rep. 1 & $<5^{*}$ & 10.90 & $<5$ & 11.57 & 22.51 & 7648.00 & 217.30 & $<5$ & 18.68 & $<5$ & 27.36 & $<5$ & NS & $<5$ \\
\hline IG_<4.76 mm_BGGEL_3(no grind) rep. 3 & $<5$ & 11.66 & $<5$ & 11.81 & 58.86 & 8362.00 & 219.40 & $<5$ & 20.32 & $<5$ & 14.39 & $<5$ & NS & $<5$ \\
\hline Average & ** & 11.42 & ** & 11.99 & 35.25 & 8208.33 & 221.00 & ** & 19.67 & ** & 19.43 & ** & & ** \\
\hline St dev & $* *$ & 0.45 & $* *$ & 0.53 & 20.47 & 501.48 & 4.71 & $* *$ & 0.87 & $* *$ & 6.95 & $* *$ & & $* *$ \\
\hline IG_<4.76 mm_BGGEL_3(ground) rep. 2 & $<5$ & $<5$ & $<5$ & $<5$ & 15.48 & 4636.00 & 179.30 & $<5$ & 11.55 & $<5$ & $<5$ & $<5$ & NS & 11.19 \\
\hline IG_<4.76 mm_BGGEL_3(ground) rep. 3 & $<5$ & $<5$ & $<5$ & $<5$ & 21.48 & 6535.00 & 207.70 & $<5$ & 14.58 & $<5$ & $<5$ & $<5$ & NS & 17.34 \\
\hline Average & $* *$ & $* *$ & ** & $* *$ & 18.10 & 5470.33 & 193.97 & $* *$ & 12.84 & $* *$ & $* *$ & $* *$ & & 14.23 \\
\hline St dev & $* *$ & $* *$ & ** & $* *$ & 3.07 & 970.23 & 14.22 & $* *$ & 1.56 & $* *$ & $* *$ & $* *$ & & 3.08 \\
\hline \% St Dev & $* *$ & $* *$ & $* *$ & $* *$ & 16.98 & 17.74 & 7.33 & $* *$ & 12.18 & ** & $* *$ & $* *$ & & 21.62 \\
\hline \multicolumn{15}{|c|}{ The initial grind sample was ground in the lab also. It was digested both ways: straight from bag; subsample taken from bag and ground in lab } \\
\hline
\end{tabular}


Table A3. Background 3 Initial Grind

\begin{tabular}{|c|c|c|c|c|c|c|c|c|c|c|c|c|c|c|}
\hline Separation Procedure & $\mathrm{Pb}$ & $\mathrm{Cr}$ & $\mathrm{Cu}$ & $\mathrm{Ni}$ & $\mathrm{Zn}$ & $\mathrm{Fe}$ & $\mathrm{Mn}$ & Mo & $\mathrm{V}$ & $\mathrm{Sb}$ & W & As & $\mathrm{Ca}$ & $\mathrm{U}$ \\
\hline IG_<4.76 mm_BGGEL_3(no grind) rep. 1 & $<5^{\star}$ & 10.90 & $<5^{\star}$ & 11.57 & 22.51 & 7648.00 & 217.30 & $<5^{\star}$ & 18.68 & $<5^{\star}$ & 27.36 & $<5^{\star}$ & NS & $<5$ \\
\hline IG_<4.76 mm_BGGEL_3(no grind) rep. 3 & $<5$ & 11.66 & $<5$ & 11.81 & 58.86 & 8362.00 & 219.40 & $<5$ & 20.32 & $<5$ & 14.39 & $<5$ & NS & $<5$ \\
\hline Average & ** & 11.42 & ** & 11.99 & 35.25 & 8208.33 & 221.00 & $* *$ & 19.67 & ** & 19.43 & ** & & ** \\
\hline St dev & ** & 0.45 & ** & 0.53 & 20.47 & 501.48 & 4.71 & $* *$ & 0.87 & ** & 6.95 & ** & & ** \\
\hline IG_<4.76 mm_BGGEL_3(ground) rep. 2 & $<5$ & $<5$ & $<5$ & $<5$ & 15.48 & 4636.00 & 179.30 & $<5$ & 11.55 & $<5$ & $<5$ & $<5$ & NS & 11.19 \\
\hline IG_<4.76 mm_BGGEL_3(ground) rep. 3 & $<5$ & $<5$ & $<5$ & $<5$ & 21.48 & 6535.00 & 207.70 & $<5$ & 14.58 & $<5$ & $<5$ & $<5$ & NS & 17.34 \\
\hline Average & $* *$ & ** & ** & $* *$ & 18.10 & 5470.33 & 193.97 & $* *$ & 12.84 & $* *$ & ** & $* *$ & & 14.23 \\
\hline St dev & $* *$ & $* *$ & ** & $* *$ & 3.07 & 970.23 & 14.22 & $* *$ & 1.56 & $* *$ & ** & $* *$ & & 3.08 \\
\hline \% St Dev & ** & ** & ** & $* *$ & 16.98 & 17.74 & 7.33 & $* *$ & 12.18 & ** & ** & ** & & 21.62 \\
\hline
\end{tabular}


Table A4. Background 4 Initial Grind

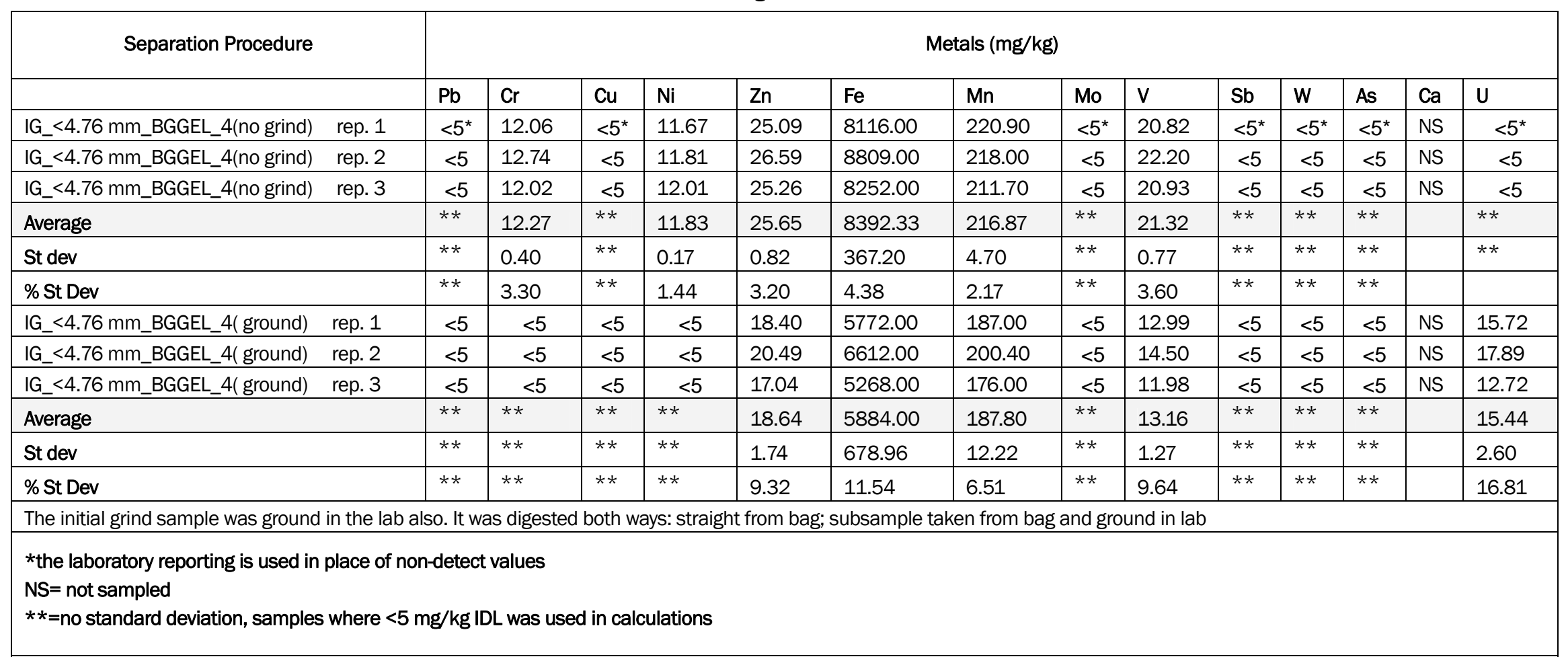


Table A5. Catch Box 1 Initial Grind

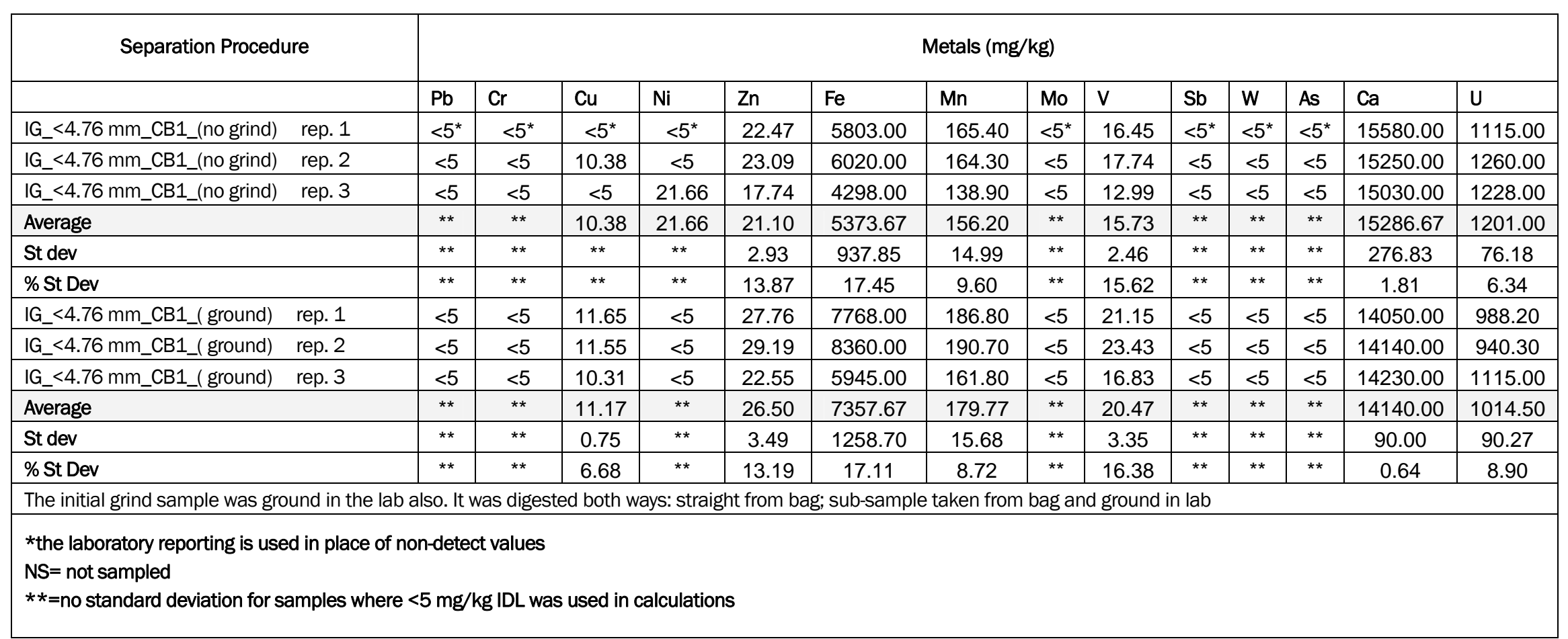


Table A6. Catch Box 2 Initial Grind

\begin{tabular}{|c|c|c|c|c|c|c|c|c|c|c|c|c|c|c|}
\hline Separation Procedure & $\mathrm{Pb}$ & $\mathrm{Cr}$ & $\mathrm{Cu}$ & $\mathrm{Ni}$ & $\mathrm{Zn}$ & $\mathrm{Fe}$ & $\mathrm{Mn}$ & Mo & $\mathrm{V}$ & $\mathrm{Sb}$ & w & As & $\mathrm{Ca}$ & $\mathrm{U}$ \\
\hline IG_<4.76 mm_CB2_(no grind) rep. 1 & $<5^{\star}$ & $<5^{\star}$ & $<5^{\star}$ & $<5^{\star}$ & $<5^{\star}$ & 1635.00 & 90.72 & $<5^{\star}$ & $<5^{\star}$ & $<5^{\star}$ & $<5^{\star}$ & $<5^{\star}$ & NS & 1441.00 \\
\hline IG_<4.76 mm_CB2_(no grind) rep. 3 & $<5$ & $<5$ & $<5$ & $<5$ & $<5$ & 1676.00 & 82.54 & $<5$ & $<5$ & $<5$ & $<5$ & $<5$ & NS & 1268.00 \\
\hline Average & $* *$ & ** & $* *$ & $* *$ & 10.74 & 1907.67 & 89.91333 & $* *$ & $* *$ & $* *$ & ** & $* *$ & & 1300.00 \\
\hline St dev & $* *$ & $* *$ & $* *$ & $* *$ & ** & 437.25 & 7.004922 & $* *$ & ** & $* *$ & $* *$ & $* *$ & & 128.04 \\
\hline IG_<4.76 mm_CB2_(ground) rep. 2 & $<5$ & $<5$ & 10.62 & $<5$ & 26.36 & 7475.00 & 178.7 & $<5$ & 21.42 & $<5$ & $<5$ & $<5$ & NS & 1068.00 \\
\hline IG_<4.76 mm_CB2_(ground) rep. 3 & $<5$ & $<5$ & 10.84 & $<5$ & 28.30 & 7723.00 & 180.4 & $<5$ & 21.90 & $<5$ & $<5$ & $<5$ & NS & 1071.00 \\
\hline Average & $* *$ & $* *$ & 10.73 & $* *$ & 27.38 & 7685.67 & 180.4667 & $* *$ & 21.80 & $* *$ & $* *$ & $* *$ & & 1066.33 \\
\hline St dev & $* *$ & $* *$ & 0.11 & $* *$ & 0.97 & 194.70 & 1.800926 & $* *$ & 0.34 & $* *$ & $* *$ & $* *$ & & 5.69 \\
\hline \% St Dev & $* *$ & $* *$ & 1.03 & $* *$ & 3.56 & 2.53 & 0.997927 & $* *$ & 1.57 & $* *$ & $* *$ & $* *$ & & 0.53 \\
\hline \multicolumn{15}{|c|}{ The initial grind sample was ground in the lab also. It was digested both ways: straight from bag; sub-sample taken from bag and ground in lab } \\
\hline
\end{tabular}


Table A7. Catch Box 3 Initial Grind

\begin{tabular}{|c|c|c|c|c|c|c|c|c|c|c|c|c|c|c|}
\hline Separation Procedure & $\mathrm{Pb}$ & $\mathrm{Cr}$ & $\mathrm{Cu}$ & $\mathrm{Ni}$ & $\mathrm{Zn}$ & $\mathrm{Fe}$ & $\mathrm{Mn}$ & Mo & $\mathrm{V}$ & $\mathrm{Sb}$ & w & As & $\mathrm{Ca}$ & $\mathrm{U}$ \\
\hline IG_<4.76 mm_CB3_(no grind) rep. 1 & $<5^{\star}$ & $<5^{\star}$ & $<5^{\star}$ & $<5^{\star}$ & 14.54 & 3483.00 & 102.00 & $<5^{\star}$ & 12.49 & $<5^{\star}$ & $<5^{\star}$ & $<5^{\star}$ & NS & 633.30 \\
\hline IG_<4.76 mm_CB3_(no grind) rep. 3 & $<5$ & $<5$ & $<5$ & $<5$ & 17.72 & 4170.00 & 138.30 & $<5$ & 15.94 & $<5$ & $<5$ & $<5$ & NS & 935.10 \\
\hline Average & ** & ** & ** & ** & 17.36 & 4157.00 & 127.37 & $* *$ & 14.97 & $* *$ & $* *$ & $* *$ & & 784.87 \\
\hline St dev & ** & ** & $* *$ & $* *$ & 2.66 & 667.59 & 22.04 & $* *$ & 2.16 & $* *$ & $* *$ & ** & & 150.90 \\
\hline IG_<4.76 mm_CB3_(ground) rep. 2 & $<5$ & $<5$ & $<5$ & $<5$ & 25.92 & 6777.00 & 163.20 & $<5$ & 20.46 & $<5$ & $<5$ & $<5$ & NS & 700.90 \\
\hline IG_<4.76 mm_CB3_(ground) rep. 3 & $<5$ & $<5$ & $<5$ & $<5$ & 25.12 & 6581.00 & 162.70 & $<5$ & 20.20 & $<5$ & $<5$ & $<5$ & NS & 775.60 \\
\hline Average & $* *$ & ** & $* *$ & $* *$ & 25.56 & 6695.00 & 163.30 & $* *$ & 20.53 & $* *$ & $* *$ & $* *$ & & 742.67 \\
\hline St dev & $* *$ & $* *$ & $* *$ & $* *$ & 0.41 & 101.84 & 0.66 & $* *$ & 0.36 & $* *$ & $* *$ & $* *$ & & 38.13 \\
\hline \% St Dev & $* *$ & $* *$ & $* *$ & $* *$ & 1.59 & 1.52 & 0.40 & $* *$ & 1.78 & $* *$ & $* *$ & $* *$ & & 5.13 \\
\hline \multicolumn{15}{|c|}{ The initial grind sample was ground in the lab also. It was digested both ways: straight from bag; sub-sample taken from bag and ground in lab } \\
\hline
\end{tabular}


Table A8. Retention Pond Initial Grind

\begin{tabular}{|c|c|c|c|c|c|c|c|c|c|c|c|c|c|c|}
\hline Separation Procedure & $\mathrm{Pb}$ & $\mathrm{Cr}$ & $\mathrm{Cu}$ & $\mathrm{Ni}$ & $\mathrm{Zn}$ & $\mathrm{Fe}$ & $\mathrm{Mn}$ & Mo & $\mathrm{v}$ & $\mathrm{Sb}$ & w & As & $\mathrm{Ca}$ & $u$ \\
\hline IG_<4.76 mm_RP_(no grind) rep. 1 & 13.09 & 25.43 & 42.64 & 23.25 & 88.68 & 17970.00 & 598.60 & $<5^{\star}$ & 48.96 & $<5^{\star}$ & 20.88 & $<5^{\star}$ & NS & 910.10 \\
\hline IG_<4.76 mm_RP_(no grind) rep. 3 & 14.92 & 24.45 & 41.15 & 22.75 & 87.11 & 17180.00 & 581.40 & $<5$ & 47.39 & $<5$ & $<5$ & $<5$ & NS & 910.20 \\
\hline Average & 13.49 & 25.27 & 42.15 & 23.27 & 89.37 & 17943.33 & 595.80 & ** & 48.44 & ** & 16.22 & $* *$ & & 904.83 \\
\hline St dev & 1.27 & 0.76 & 0.87 & 0.53 & 2.67 & 750.36 & 13.22 & $* *$ & 0.91 & $* *$ & 6.59 & $* *$ & & 9.21 \\
\hline IG_<4.76 mm_RP_(ground) rep. 2 & 13.10 & 25.91 & 44.14 & 24.45 & 90.47 & 18430.00 & 621.10 & $<5$ & 47.87 & $<5$ & $<5$ & $<5$ & NS & 1155.00 \\
\hline IG_<4.76 mm_RP_(ground) rep. 3 & 13.07 & 24.38 & 42.98 & 23.56 & 87.26 & 17400.00 & 605.50 & $<5$ & 46.81 & $<5$ & $<5$ & $<5$ & NS & 1176.00 \\
\hline Average & 13.58 & 25.77 & 44.08 & 24.34 & 90.15 & 18373.33 & 619.37 & $* *$ & 48.29 & $* *$ & $* *$ & $* *$ & & 1160.67 \\
\hline St dev & 0.86 & 1.33 & 1.07 & 0.73 & 2.74 & 946.27 & 13.09 & $* *$ & 1.73 & $* *$ & $* *$ & $* *$ & & 13.43 \\
\hline$\%$ St Dev & 6.36 & 5.16 & 2.42 & 3.00 & 3.04 & 5.15 & 2.11 & ** & 3.59 & ** & ** & ** & & 1.16 \\
\hline
\end{tabular}


Table A9. Range 20-1 Initial Grind

\begin{tabular}{|c|c|c|c|c|c|c|c|c|c|c|c|c|c|c|}
\hline & $\mathrm{Pb}$ & $\mathrm{Cr}$ & $\mathrm{Cu}$ & $\mathrm{Ni}$ & $\mathrm{Zn}$ & $\mathrm{Fe}$ & $\mathrm{Mn}$ & Mo & $\mathrm{V}$ & $\mathrm{Sb}$ & w & As & $\mathrm{Ca}$ & $\mathrm{U}$ \\
\hline IG_<4.76 mm_R20-1_(no grind) rep. 1 & $<5$ & 16.64 & 40.38 & $<5$ & 15.58 & 4584.00 & 177.50 & $<5^{*}$ & 29.35 & $<5^{\star}$ & $<5^{*}$ & $<5^{*}$ & 31260.00 & 8928.00 \\
\hline IG_<4.76 mm_R2O-1_(no grind) rep. 3 & 10.17 & 18.27 & 42.00 & 10.40 & 18.71 & 5476.00 & 195.22 & $<5$ & 32.14 & $<5$ & $<5$ & $<5$ & 29640.00 & 8866.00 \\
\hline Average & 11.28 & 17.22 & 41.67 & 10.40 & 16.31 & 4606.00 & 179.13 & ** & 30.70 & ** & ** & ** & 30080.00 & 9320.00 \\
\hline St dev & 1.56 & 0.91 & 1.16 & ** & 2.13 & 859.21 & 15.34 & $* *$ & 1.40 & $* *$ & ** & $* *$ & 1032.86 & 733.31 \\
\hline IG_<4.76 mm_R2O-1_(ground) rep. 2 & $<5$ & 17.26 & 38.20 & 10.12 & 18.83 & 5855.00 & 210.40 & $<5$ & 32.48 & $<5$ & $<5$ & $<5$ & 28040.00 & 7649.00 \\
\hline IG_<4.76 mm_R20-1_(ground) rep. 3 & 10.68 & 17.34 & 38.08 & 10.03 & 18.29 & 5702.00 & 202.90 & $<5$ & 32.57 & $<5$ & $<5$ & $<5$ & 26570.00 & 7620.00 \\
\hline Average & 10.79 & 18.54 & \begin{tabular}{|l|}
39.46 \\
\end{tabular} & \begin{tabular}{|l|}
11.13 \\
\end{tabular} & 21.03 & 6720.00 & 219.77 & $* *$ & 34.82 & $* *$ & $* *$ & $* *$ & 27480.00 & 7301.33 \\
\hline St dev & 0.16 & 2.15 & 2.28 & 1.83 & 4.29 & 1632.52 & 23.03 & $* *$ & 3.97 & $* *$ & ** & $* *$ & 795.05 & 577.24 \\
\hline$\%$ St Dev & 1.44 & 11.59 & 5.78 & 16.47 & 20.38 & 24.29 & 10.48 & $* *$ & 11.40 & $* *$ & ** & $* *$ & 2.89 & 7.91 \\
\hline
\end{tabular}


Table A10. Range 20-2 Initial Grind A

\begin{tabular}{|c|c|c|c|c|c|c|c|c|c|c|c|c|c|c|}
\hline & $\mathrm{Pb}$ & $\mathrm{Cr}$ & $\mathrm{Cu}$ & $\mathrm{Ni}$ & $\mathrm{Zn}$ & $\mathrm{Fe}$ & $\mathrm{Mn}$ & Mo & $\mathrm{v}$ & $\mathrm{Sb}$ & w & As & $\mathrm{Ca}$ & $\mathrm{U}$ \\
\hline IG_<4.76 mm_R2O-2_(no grind) rep. 1 & 22.79 & 22.18 & 45.62 & 14.93 & 29.00 & 9113.00 & 245.80 & $<5^{*}$ & 43.35 & $<5^{*}$ & $<5^{\star}$ & $<5^{\star}$ & NS & 12780.00 \\
\hline IG_<4.76 mm_R2O-2_(no grind) rep. 3 & 23.77 & 23.13 & 46.99 & 14.71 & 29.23 & 8886.00 & 247.10 & $<5$ & 43.51 & $<5$ & $<5$ & $<5$ & NS & 13340.00 \\
\hline Average & 23.77 & 22.96 & 47.12 & 14.89 & 29.26 & 9012.00 & 248.17 & ** & 43.71 & ** & $* *$ & ** & & 13026.67 \\
\hline St dev & 0.98 & 0.71 & 1.57 & 0.16 & 0.27 & 115.55 & 3.04 & ** & 0.50 & ** & $* *$ & $* *$ & & 285.89 \\
\hline IG_<4.76 mm_R2O-2_(ground) rep. 2 & 25.37 & 24.31 & 47.23 & 15.12 & 30.70 & 10190.00 & 258.00 & $<5$ & 47.19 & $<5$ & $<5$ & $<5$ & NS & 13120.00 \\
\hline IG_<4.76 mm_R2O-2_(ground) rep. 3 & 24.88 & 22.76 & 47.29 & 14.94 & 31.64 & 8974.00 & 251.60 & $<5$ & 45.74 & $<5$ & $<5$ & $<5$ & NS & 13120.00 \\
\hline Average & 24.62 & 23.18 & 47.06 & 14.85 & 30.48 & 9155.67 & 250.80 & $* *$ & 45.45 & $* *$ & $* *$ & $* *$ & & 13106.67 \\
\hline St dev & 0.91 & 0.99 & 0.35 & 0.33 & 1.29 & 956.53 & 7.63 & $* *$ & 1.90 & $* *$ & $* *$ & $* *$ & & 23.09 \\
\hline$\%$ St Dev & 3.69 & 4.25 & 0.75 & 2.22 & 4.23 & 10.45 & 3.04 & $* *$ & 4.18 & $* *$ & $* *$ & $* *$ & & 0.18 \\
\hline
\end{tabular}


Table A11. Range 20-2 Initial Grind B

\begin{tabular}{|c|c|c|c|c|c|c|c|c|c|c|c|c|c|c|}
\hline & $\mathrm{Pb}$ & $\mathrm{Cr}$ & $\mathrm{Cu}$ & $\mathrm{Ni}$ & $\mathrm{Zn}$ & $\mathrm{Fe}$ & $\mathrm{Mn}$ & Mo & $\mathrm{v}$ & $\mathrm{Sb}$ & W & As & $\mathrm{Ca}$ & $\mathrm{U}$ \\
\hline IG_<4.76 mm_R2O-2_(no grind) rep. 1 & 24.17 & 22.06 & 42.97 & 14.39 & 28.13 & 9030.00 & 244.40 & $<5^{\star}$ & 42.22 & $<5^{\star}$ & $<5^{\star}$ & $<5^{\star}$ & NS & 11870.00 \\
\hline IG_<4.76 mm_R2O-2_(no grind) rep. 3 & 24.56 & 22.64 & 43.20 & 14.49 & 28.88 & 9030.00 & 248.90 & $<5$ & 43.08 & $<5$ & $<5$ & $<5$ & NS & 12620.00 \\
\hline Average & 23.68 & 22.09 & 43.53 & 14.48 & 27.96 & 8874.33 & 247.10 & ** & 42.25 & ** & $* *$ & ** & & 12270.00 \\
\hline St dev & 1.20 & 0.54 & 0.79 & 0.09 & 1.02 & 269.62 & 2.38 & $* *$ & 0.82 & ** & $* *$ & ** & & 377.49 \\
\hline IG_<4.76 mm_R20-2_(ground) rep. 2 & 23.10 & 21.51 & 41.77 & 14.18 & 26.94 & 8517.00 & 247.50 & $<5$ & 41.76 & $<5$ & $<5$ & $<5$ & NS & 11820.00 \\
\hline IG_<4.76 mm_R2O-2_(ground) rep. 3 & 22.19 & 21.62 & 41.99 & 13.96 & 28.55 & 8777.00 & 246.90 & $<5$ & 41.61 & $<5$ & $<5$ & $<5$ & NS & 11760.00 \\
\hline Average & 22.77 & 21.72 & 41.81 & 14.23 & 28.46 & 8843.33 & 248.40 & $* *$ & 42.06 & $* *$ & $* *$ & $* *$ & & 11750.00 \\
\hline St dev & 0.50 & 0.27 & 0.16 & 0.30 & 1.48 & 364.06 & 2.10 & $* *$ & 0.65 & $* *$ & $* *$ & $* *$ & & 75.50 \\
\hline$\%$ St Dev & 2.20 & 1.26 & 0.38 & 2.13 & 5.19 & 4.12 & 0.85 & $* *$ & 1.55 & $* *$ & $* *$ & $* *$ & & 0.64 \\
\hline \multicolumn{15}{|c|}{ The initial grind sample was ground in the lab also. It was digested both ways: straight from bag; sub-sample taken from bag and ground in lab } \\
\hline
\end{tabular}


Table A12. Range 20-3 Initial Grind

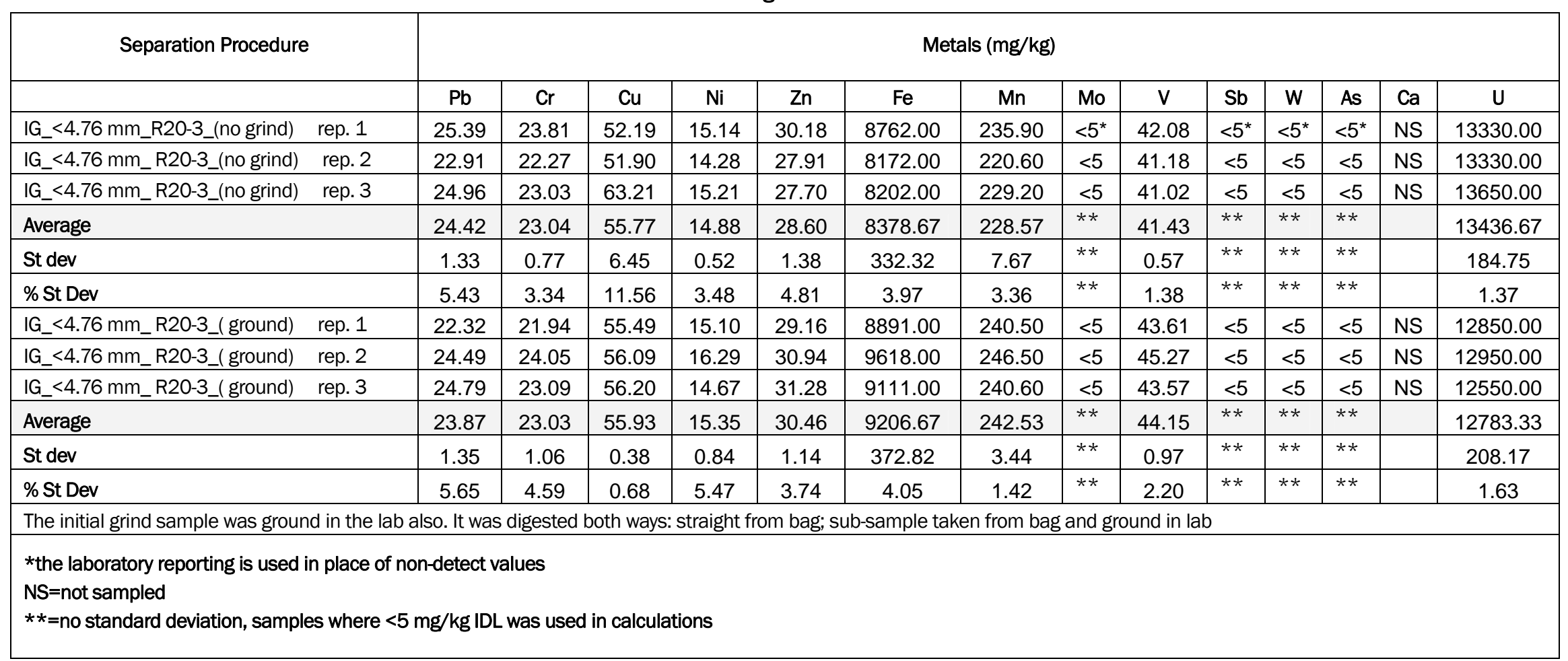


Table A13. DU Garden Lift 1 Initial Grind

\begin{tabular}{|c|c|c|c|c|c|c|c|c|c|c|c|c|c|c|}
\hline & $\mathrm{Pb}$ & $\mathrm{Cr}$ & $\mathrm{Cu}$ & $\mathrm{Ni}$ & $\mathrm{Zn}$ & $\mathrm{Fe}$ & $\mathrm{Mn}$ & Mo & $\mathrm{v}$ & $\mathrm{Sb}$ & w & As & $\mathrm{Ca}$ & $\mathrm{U}$ \\
\hline IG_<4.76 mm_DG-1_(no grind) rep. 1 & $<5^{\star}$ & $<5^{\star}$ & $<5^{\star}$ & $<5^{\star}$ & 20.23 & 4929.00 & 213.60 & $<5^{\star}$ & 10.41 & $<5^{\star}$ & $<5^{\star}$ & $<5^{\star}$ & NS & $<5$ \\
\hline IG_<4.76 mm_DG-1_(no grind) rep. 3 & $<5$ & $<5$ & $<5$ & $<5$ & 21.61 & 5266.00 & 221.30 & $<5$ & 10.72 & $<5$ & $<5$ & $<5$ & NS & $<5$ \\
\hline Average & $* *$ & $* *$ & ** & ** & 21.01 & 5152.33 & 220.77 & ** & 10.70 & $* *$ & $* *$ & $* *$ & & $* *$ \\
\hline St dev & $* *$ & $* *$ & $* *$ & ** & 0.71 & 193.42 & 6.92 & $* *$ & 0.28 & $* *$ & $* *$ & ** & & $* *$ \\
\hline$I \mathrm{IG}_{-}<4.76$ mm_DG-1_(ground) rep. 2 & $<5$ & $<5$ & $<5$ & $<5$ & 20.20 & 5210.00 & 207.80 & $<5$ & 10.50 & $<5$ & $<5$ & $<5$ & NS & $<5$ \\
\hline IG_<4.76 mm_DG-1_(ground) rep. 3 & $<5$ & $<5$ & $<5$ & $<5$ & 19.11 & 4875.00 & 204.80 & $<5$ & $<5$ & $<5$ & $<5$ & $<5$ & NS & $<5$ \\
\hline Average & ** & ** & $* *$ & ** & 20.74 & 5323.67 & 209.77 & $* *$ & 11.13 & $* *$ & $* *$ & $* *$ & & $* *$ \\
\hline St dev & $* *$ & ** & $* *$ & ** & 1.95 & 515.00 & 6.19 & ** & 0.89 & $* *$ & $* *$ & ** & & $* *$ \\
\hline$\%$ St Dev & $* *$ & ** & $* *$ & ** & 9.41 & 9.67 & 2.95 & ** & 8.00 & $* *$ & $* *$ & ** & & $* *$ \\
\hline
\end{tabular}


Table A14. DU Garden Lift 2 Initial Grind

\begin{tabular}{|c|c|c|c|c|c|c|c|c|c|c|c|c|c|c|}
\hline & $\mathrm{Pb}$ & $\mathrm{Cr}$ & $\mathrm{Cu}$ & $\mathrm{Ni}$ & $\mathrm{Zn}$ & $\mathrm{Fe}$ & $\mathrm{Mn}$ & Mo & $\mathrm{v}$ & $\mathrm{Sb}$ & W & As & $\mathrm{Ca}$ & u \\
\hline IG_<4.76 mm_DG-2_(no grind) rep. 1 & $<5^{\star}$ & $<5^{\star}$ & $<5^{\star}$ & 10.80 & 24.60 & 6692.00 & 233.50 & $<5^{\star}$ & 13.65 & $<5^{\star}$ & $<5^{\star}$ & $<5^{\star}$ & NS & $<5^{\star}$ \\
\hline IG_<4.76 mm_DG-2_(no grind) rep. 3 & $<5$ & $<5$ & $<5$ & 10.10 & 23.59 & 6171.00 & 227.60 & $<5$ & 13.06 & $<5$ & $<5$ & $<5$ & NS & $<5$ \\
\hline Average & ** & $* *$ & $* *$ & 10.60 & 24.50 & 6576.00 & 232.57 & ** & 13.86 & $* *$ & ** & $* *$ & & $* *$ \\
\hline St dev & $* *$ & ** & $* *$ & 0.44 & 0.86 & 361.25 & 4.57 & $* *$ & 0.92 & $* *$ & ** & $* *$ & & ** \\
\hline$I \mathrm{IG}_{-}<4.76 \mathrm{~mm} \_$DG-2_(ground) rep. 2 & $<5$ & $<5$ & $<5$ & 10.83 & 26.05 & 7221.00 & 236.40 & $<5$ & 15.59 & $<5$ & $<5$ & $<5$ & NS & $<5$ \\
\hline IG_<4.76 mm_DG-2_(ground) rep. 3 & $<5$ & $<5$ & $<5$ & 10.85 & 25.66 & 7192.00 & 243.50 & $<5$ & 15.35 & $<5$ & $<5$ & $<5$ & NS & $<5$ \\
\hline Average & $* *$ & $* *$ & $* *$ & 11.52 & 25.73 & 7082.00 & 239.17 & $* *$ & 15.36 & $* *$ & $* *$ & $* *$ & & $* *$ \\
\hline St dev & $* *$ & $* *$ & $* *$ & 1.18 & 0.29 & 216.13 & 3.80 & $* *$ & 0.22 & $* *$ & $* *$ & $* *$ & & $* *$ \\
\hline \% St Dev & $* *$ & $* *$ & $* *$ & 10.27 & 1.12 & 3.05 & 1.59 & $* *$ & 1.43 & $* *$ & $* *$ & $* *$ & & $* *$ \\
\hline
\end{tabular}


Table A15. DU Garden Lift 3 Initial Grind

\begin{tabular}{|c|c|c|c|c|c|c|c|c|c|c|c|c|c|c|}
\hline & $\mathrm{Pb}$ & $\mathrm{Cr}$ & $\mathrm{Cu}$ & $\mathrm{Ni}$ & $\mathrm{Zn}$ & $\mathrm{Fe}$ & $\mathrm{Mn}$ & Mo & $\mathrm{v}$ & $\mathrm{Sb}$ & w & As & $\mathrm{Ca}$ & $\mathrm{u}$ \\
\hline IG_<4.76 mm_DG-3_(no grind) rep. 1 & $<5^{\star}$ & $<5^{\star}$ & 15.9 & $<5^{\star}$ & 22.92 & 4640.00 & 204.60 & $<5^{*}$ & $<5^{\star}$ & $<5^{\star}$ & $<5^{\star}$ & $<5^{\star}$ & NS & $<5$ \\
\hline IG_<4.76 mm_DG-3_(no grind) rep. 3 & $<5$ & $<5$ & $<5$ & $<5$ & 21.32 & 5292.00 & 202.60 & $<5$ & $<5$ & $<5$ & $<5$ & $<5$ & NS & $<5$ \\
\hline Average & $* *$ & ** & 13.04 & $* *$ & 22.05 & 5009.67 & 204.23 & ** & $* *$ & $* *$ & $* *$ & $* *$ & & $* *$ \\
\hline St dev & $* *$ & $* *$ & 4.05 & $* *$ & 0.81 & 334.66 & 1.48 & $* *$ & $* *$ & ** & $* *$ & ** & & ** \\
\hline$I \mathrm{IG}_{-}<4.76$ mm_DG-3_(ground) rep. 2 & $<5$ & $<5$ & 18.25 & 11.90 & 30.48 & 6925.00 & 235.10 & $<5$ & 11.90 & $<5$ & $<5$ & $<5$ & NS & $<5$ \\
\hline IG_<4.76 mm_DG-3_(ground) rep. 3 & $<5$ & $<5$ & 13.44 & 11.19 & 26.92 & 6575.00 & 225.30 & $<5$ & 11.13 & $<5$ & $<5$ & $<5$ & NS & $<5$ \\
\hline Average & ** & ** & 21.61 & 11.84 & 30.50 & 6733.00 & 229.90 & $* *$ & 11.51 & ** & $* *$ & $* *$ & NS & $* *$ \\
\hline St dev & $* *$ & ** & 10.27 & 0.62 & 3.60 & 177.46 & 4.93 & $* *$ & 0.39 & ** & $* *$ & $* *$ & NS & ** \\
\hline$\%$ St Dev & $* *$ & ** & 47.51 & 5.25 & 11.79 & 2.64 & 2.14 & ** & 3.35 & ** & $* *$ & $* *$ & NS & $* *$ \\
\hline
\end{tabular}


Table A16. DU Garden Lift 4 Initial Grind

\begin{tabular}{|c|c|c|c|c|c|c|c|c|c|c|c|c|c|c|}
\hline & $\mathrm{Pb}$ & $\mathrm{Cr}$ & $\mathrm{Cu}$ & $\mathrm{Ni}$ & $\mathrm{Zn}$ & $\mathrm{Fe}$ & $\mathrm{Mn}$ & Mo & $\mathrm{V}$ & $\mathrm{Sb}$ & W & As & $\mathrm{Ca}$ & U \\
\hline IG_<4.76 mm_DG-4_(no grind) rep. 1 & 37.98 & 29.93 & 43.61 & 15.12 & 27.31 & 8008.00 & 234.90 & $<5^{\star}$ & 44.34 & $<5^{\star}$ & $<5^{\star}$ & $<5^{\star}$ & NS & 22160.00 \\
\hline IG_<4.76 mm_DG-4_(no grind) rep. 3 & 36.25 & 30.66 & 43.65 & 15.46 & 28.50 & 8298.00 & 239.40 & $<5$ & 43.73 & $<5$ & $<5$ & $<5$ & NS & 21700.00 \\
\hline Average & 36.99 & 30.02 & 43.24 & 15.10 & 28.15 & 8133.00 & 236.83 & ** & 43.36 & $* *$ & ** & $* *$ & & 21510.00 \\
\hline St dev & 0.89 & 0.60 & 0.67 & 0.37 & 0.73 & 149.08 & 2.32 & $* *$ & 1.21 & ** & ** & ** & & 762.95 \\
\hline IG_<4.76 mm_DG-4_(ground) rep. 2 & 30.98 & 38.97 & 30.05 & 15.40 & 28.13 & 8108.00 & 236.60 & $<5$ & 65.19 & $<5$ & $<5$ & $<5$ & NS & 20150.00 \\
\hline IG_<4.76 mm_DG-4_(ground) rep. 3 & 31.34 & 40.85 & 30.86 & 16.59 & 28.07 & 9013.00 & 238.10 & $<5$ & 68.60 & $<5$ & $<5$ & $<5$ & NS & 20220.00 \\
\hline Average & 31.26 & 39.70 & 30.25 & 16.02 & 28.94 & 8509.67 & 235.33 & $* *$ & 65.94 & ** & ** & $* *$ & & 20076.67 \\
\hline St dev & 0.25 & 1.01 & 0.53 & 0.60 & 1.46 & 460.99 & 3.57 & $* *$ & 2.37 & $* *$ & $* *$ & $* *$ & & 190.88 \\
\hline$\%$ St Dev & 0.80 & 2.54 & 1.77 & 3.73 & 5.03 & 5.42 & 1.52 & $* *$ & 3.60 & $* *$ & $* *$ & $* *$ & & 0.95 \\
\hline
\end{tabular}


Table A17. DU Garden Lift 5 Initial Grind

\begin{tabular}{|c|c|c|c|c|c|c|c|c|c|c|c|c|c|c|}
\hline & $\mathrm{Pb}$ & $\mathrm{Cr}$ & $\mathrm{Cu}$ & $\mathrm{Ni}$ & $\mathrm{Zn}$ & $\mathrm{Fe}$ & $\mathrm{Mn}$ & Mo & $\mathrm{V}$ & $\mathrm{Sb}$ & W & As & $\mathrm{Ca}$ & U \\
\hline IG_<4.76 mm_DG-5_(no grind) rep. 1 & 50.98 & 57.09 & 43.33 & 15.71 & 19.90 & 5127.00 & 196.50 & $<5^{\star}$ & 84.51 & $<5^{\star}$ & $<5^{\star}$ & $<5^{\star}$ & NS & 36290.00 \\
\hline IG_<4.76 mm_DG-5_(no grind) rep. 3 & 52.69 & 56.59 & 43.22 & 15.94 & 20.41 & 5288.00 & 198.10 & $<5$ & 84.96 & $<5$ & $<5$ & $<5$ & NS & 35890.00 \\
\hline Average & 52.08 & 56.81 & 43.19 & 15.95 & 20.59 & 5414.33 & 201.97 & ** & 84.09 & $* *$ & ** & $* *$ & & 35683.33 \\
\hline St dev & 0.95 & 0.26 & 0.15 & 0.25 & 0.80 & 367.18 & 8.12 & $* *$ & 1.15 & ** & ** & ** & & 732.21 \\
\hline IG_<4.76 mm_DG-5_(ground) rep. 2 & 47.84 & 54.99 & 40.91 & 16.13 & 21.16 & 6071.00 & 214.30 & $<5$ & 81.35 & $<5$ & $<5$ & $<5$ & NS & 33740.00 \\
\hline IG_<4.76 mm_DG-5_(ground) rep. 3 & 47.47 & 53.38 & 40.01 & 16.82 & 22.86 & 5486.00 & 201.90 & $<5$ & 78.54 & $<5$ & $<5$ & $<5$ & NS & 33100.00 \\
\hline Average & 47.75 & 53.89 & 40.68 & 16.50 & 21.41 & 5822.00 & 212.43 & $* *$ & 79.56 & ** & ** & $* *$ & & 33290.00 \\
\hline St dev & 0.24 & 0.95 & 0.59 & 0.35 & 1.34 & 302.05 & 9.74 & $* *$ & 1.55 & $* *$ & $* *$ & $* *$ & & 391.28 \\
\hline$\%$ St Dev & 0.51 & 1.76 & 1.45 & 2.11 & 6.25 & 5.19 & 4.58 & $* *$ & 1.95 & $* *$ & $* *$ & $* *$ & & 1.18 \\
\hline
\end{tabular}




\section{Appendix B. Dry Sieve Separation}


Table B1. Background 1 Dry Sieve

\begin{tabular}{|c|c|c|c|c|c|c|c|c|c|c|c|c|c|c|}
\hline \multirow[t]{2}{*}{ Separation Process } & \multicolumn{14}{|c|}{ Metals Concentration (mg/kg) } \\
\hline & $\mathrm{Pb}$ & $\mathrm{Cr}$ & $\mathrm{Cu}$ & $\mathrm{Ni}$ & $\mathrm{Zn}$ & $\mathrm{Fe}$ & $\mathrm{Mn}$ & Mo & $\mathrm{V}$ & $\mathrm{Sb}$ & W & As & $\mathrm{Ca}$ & $U * \star \star$ \\
\hline DS_>4_BGGEL_1 rep. 1 & NDT & NDT & NDT & NDT & NDT & NDT & NDT & NDT & NDT & NDT & NDT & NDT & ND & \multirow{3}{*}{$<5^{*}$} \\
\hline DS >4 $\quad$ BGGEL 1 rep. 2 & NDT & NDT & NDT & NDT & NDT & NDT & NDT & NDT & NDT & NDT & NDT & NDT & ND & \\
\hline DS_>4_BGGEL_1 rep. 3 & NDT & NDT & NDT & NDT & NDT & NDT & NDT & NDT & NDT & NDT & NDT & NDT & ND & \\
\hline \multicolumn{15}{|l|}{ Average } \\
\hline \multicolumn{15}{|l|}{ St dev } \\
\hline \multicolumn{15}{|l|}{ \% St Dev } \\
\hline DS_>10_BGGEL_1 rep. 1 & $<5 *$ & $<5 *$ & $<5 *$ & $<5^{*}$ & 15.43 & 4331.00 & 157.50 & $<5 *$ & 11.09 & $<5^{*}$ & $<5^{*}$ & $<5 *$ & ND & $<5 *$ \\
\hline DS_>10_BGGEL_1 rep. 2 & $<5$ & $<5$ & $<5$ & $<5$ & 14.03 & 4366.00 & 162.60 & $<5$ & 11.38 & $<5$ & $<5$ & $<5$ & ND & $<5$ \\
\hline DS_>10_BGGEL_1 rep. 3 & $<5$ & $<5$ & $<5$ & $<5$ & 13.39 & 4089.00 & 159.60 & $<5$ & 10.93 & $<5$ & $<5$ & $<5$ & ND & $<5$ \\
\hline Average & $<5$ & $<5$ & $<5$ & $<5$ & 14.28 & 4262.00 & 159.90 & $<5$ & 11.13 & $<5$ & $<5$ & $<5$ & ND & $<5$ \\
\hline St dev & $* *$ & $* *$ & $* *$ & $* *$ & 1.04 & 150.84 & 2.56 & $* *$ & 0.23 & $* *$ & $* *$ & $* *$ & & $* *$ \\
\hline$\%$ St Dev & $* *$ & $* *$ & $* *$ & $* *$ & 7.30 & 3.54 & 1.60 & $* *$ & 2.05 & $* *$ & $* *$ & $* *$ & & $* *$ \\
\hline DS_>50_BGGEL_1 rep. 1 & $<5 *$ & $<5 *$ & $<5 *$ & $<5 *$ & 24.56 & 7049.00 & 218.60 & $<5 *$ & 12.55 & $<5 *$ & $<5^{*}$ & $<5 *$ & ND & $<5 *$ \\
\hline DS_>50_BGGEL_1 rep. 2 & $<5$ & $<5$ & $<5$ & $<5$ & 18.29 & 4632.00 & 197.00 & $<5$ & 0.05 & $<5$ & $<5$ & $<5$ & ND & $<5$ \\
\hline DS_>50_BGGEL_1 rep. 3 & $<5$ & $<5$ & $<5$ & $<5$ & 18.07 & 4556.00 & 191.90 & $<5$ & 0.05 & $<5$ & $<5$ & $<5$ & ND & $<5$ \\
\hline Average & $<5$ & $<5$ & $<5$ & $<5$ & 20.31 & 5412.33 & 202.50 & $<5$ & 4.22 & $<5$ & $<5$ & $<5$ & ND & $<5$ \\
\hline St dev & $* *$ & $* *$ & ** & $* *$ & 3.69 & 1417.90 & 14.17 & $* *$ & 7.22 & $* *$ & ** & ** & & $\star *$ \\
\hline \% St Dev & $* *$ & $* *$ & $* *$ & $* *$ & 18.15 & 26.20 & 7.00 & $* *$ & 171.15 & $* *$ & $* *$ & $* *$ & & $* *$ \\
\hline DS_<5_BGGEL_1 rep. 1 & 0.05 & $<5^{*}$ & $<5 *$ & $<* 5 *$ & 25.52 & 7336.00 & 195.20 & $<5 *$ & 13.25 & $<5 *$ & $<5 *$ & $<5 *$ & ND & $<5 *$ \\
\hline DS_<5_BGGEL_1 rep. 2 & 0.05 & $<5$ & $<5$ & $<5$ & 23.91 & 6536.00 & 188.00 & $<5$ & 12.12 & $<5$ & $<5$ & $<5$ & ND & $<5$ \\
\hline DS_<5_BGGEL_1 rep. 3 & 10.97 & $<5$ & $<5$ & $<5$ & 23.38 & 6194.00 & 188.10 & $<5$ & 11.22 & $<5$ & $<5$ & $<5$ & ND & $<5$ \\
\hline Average & 3.69 & $<5$ & $<5$ & $<5$ & 24.27 & 6688.67 & 190.43 & $<5$ & 12.20 & $<5$ & $<5$ & $<5$ & ND & $<5$ \\
\hline St dev & 6.30 & ** & $* *$ & ** & 1.11 & 586.11 & 4.13 & $* *$ & 1.02 & $* *$ & ** & $* *$ & & ** \\
\hline$\%$ St Dev & 170.86 & $* *$ & $* *$ & $* *$ & 4.59 & 8.76 & 2.17 & $* *$ & 8.34 & $* *$ & $* *$ & $* *$ & & $* *$ \\
\hline $\begin{array}{l}\text { NDT }=\text { not determined. Samp } \\
\text { ND - non-detect } \\
\text { *the laboratory reporting is } \\
\text { **-no standard deviation for } \\
\text { *** - concentration determir }\end{array}$ & $\begin{array}{l}\text { ed of larg } \\
\text { where of non }<5\end{array}$ & ks. & & 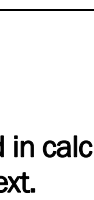 & ons. & & & & & & & & & \\
\hline
\end{tabular}


Table B2. Background 2 Dry Sieve

\begin{tabular}{|c|c|c|c|c|c|c|c|c|c|c|c|c|c|c|}
\hline \multirow[t]{2}{*}{ Separation Procedure } & \multicolumn{14}{|c|}{ Metals (mg/kg) } \\
\hline & $\mathrm{Pb}$ & $\mathrm{Cr}$ & $\mathrm{Cu}$ & $\mathrm{Ni}$ & $\mathrm{Zn}$ & $\mathrm{Fe}$ & $\mathrm{Mn}$ & Mo & V & $\mathrm{Sb}$ & W & As & $\mathrm{Ca}$ & $\mathrm{U} * * *$ \\
\hline DS_>4_BGGEL_2 rep. 1 & NDT & NDT & NDT & NDT & NDT & NDT & NDT & NDT & NDT & NDT & NDT & NDT & NS & \\
\hline DS_>4_BGGEL_2 rep. 2 & NDT & NDT & NDT & NDT & NDT & NDT & NDT & NDT & NDT & NDT & NDT & NDT & NS & \\
\hline DS_>4_BGGEL_2 rep. 3 & NDT & NDT & NDT & NDT & NDT & NDT & NDT & NDT & NDT & NDT & NDT & NDT & NS & $<5 *$ \\
\hline \multicolumn{15}{|l|}{ Average } \\
\hline \multicolumn{15}{|l|}{ St dev } \\
\hline \multicolumn{15}{|l|}{$\%$ St Dev } \\
\hline DS_>10_BGGEL_2 rep. 1 & $<5^{*}$ & $<5 *$ & $<5^{*}$ & $<5 *$ & 14.40 & 3602.00 & 233.40 & $<5^{*}$ & $<5 *$ & $<5^{*}$ & $<5^{*}$ & $<5^{*}$ & NS & $<5^{*}$ \\
\hline DS_>10_BGGEL_2 rep. 2 & $<5$ & $<5$ & $<5$ & $<5$ & 14.97 & 4049.00 & 210.00 & $<5$ & $<5$ & $<5$ & $<5$ & $<5$ & NS & $<5$ \\
\hline DS_>10_BGGEL_2 rep. 3 & $<5$ & $<5$ & $<5$ & $<5$ & 13.83 & 3635.00 & 225.00 & $<5$ & $<5$ & $<5$ & $<5$ & $<5$ & NS & $<5$ \\
\hline Average & $<5$ & $<5$ & $<5$ & $<5$ & 14.40 & 3762.00 & 222.80 & $<5$ & $<5$ & $<5$ & $<5$ & $<5$ & & $<5$ \\
\hline St dev & $* *$ & $* *$ & $* *$ & $* *$ & 0.57 & 249.10 & 11.85 & $* *$ & $* *$ & $* *$ & $* *$ & $* *$ & & $* *$ \\
\hline \% St Dev & $* *$ & $* *$ & $* *$ & $* *$ & 3.96 & 6.62 & 5.32 & $* *$ & $* *$ & $* *$ & $* *$ & $* *$ & & $* *$ \\
\hline DS_>50_BGGEL_2 rep. 1 & $<5^{*}$ & 10.87 & $<5 *$ & 12.76 & 25.76 & 8346.00 & 257.70 & $<5 *$ & 16.67 & $<5 *$ & $<5^{*}$ & $<5 *$ & NS & $<5 *$ \\
\hline DS_>50_BGGEL_2 rep. 2 & $<5$ & 11.26 & $<5$ & 13.02 & 26.25 & 8617.00 & 256.90 & $<5$ & 17.36 & $<5$ & $<5$ & $<5$ & NS & $<5$ \\
\hline DS_>50_BGGEL_2 rep. 3 & $<5$ & 11.29 & $<5$ & 13.55 & 27.17 & 8681.00 & 263.60 & $<5$ & 17.55 & $<5$ & $<5$ & $<5$ & NS & $<5$ \\
\hline Average & $<5$ & 11.14 & $<5$ & 13.11 & 26.39 & 8548.00 & 259.40 & $<5$ & 17.19 & $<5$ & $<5$ & $<5$ & & $<5$ \\
\hline St dev & $* *$ & 0.23 & $* *$ & 0.40 & 0.72 & 177.84 & 3.66 & $* *$ & 0.46 & $* *$ & $* *$ & $* *$ & & $* *$ \\
\hline$\%$ St Dev & $* *$ & 2.10 & $* *$ & 3.07 & 2.71 & 2.08 & 1.41 & ** & 2.69 & $* *$ & $* *$ & $* *$ & & $* *$ \\
\hline DS_<0.05_BGGEL_2 rep. 1 & $<5^{*}$ & $<5^{*}$ & $<5^{*}$ & 10.17 & 24.45 & 7647.00 & 217.00 & $<5$ & 14.17 & $<5$ & $<5$ & $<5$ & NS & $<5$ \\
\hline DS_<0.05_BGGEL_2 rep. 2 & $<5$ & $<5$ & $<5$ & $<5$ & 16.83 & 4858.00 & 187.40 & $<5$ & ND & $<5$ & $<5$ & $<5$ & NS & $<5$ \\
\hline DS_<0.05_BGGEL_2 rep. 3 & $<5$ & $<5$ & $<5$ & $<5$ & 17.09 & 4952.00 & 192.70 & $<5$ & $<5$ & $<5$ & $<5$ & $<5$ & NS & $<5$ \\
\hline Average & $* *$ & $* *$ & $* *$ & 10.17 & 19.46 & 5819.00 & 199.03 & $* *$ & 14.17 & $* *$ & $* *$ & $* *$ & & $* *$ \\
\hline St dev & $* *$ & $* *$ & $* *$ & $* *$ & 4.33 & 1583.79 & 15.78 & $* *$ & $* *$ & $* *$ & $* *$ & $* *$ & & $* *$ \\
\hline$\%$ St Dev & $* *$ & $* *$ & $* *$ & $* *$ & 22.24 & 27.22 & 7.93 & $* *$ & $* *$ & $* *$ & $* *$ & $* *$ & & $* *$ \\
\hline \multicolumn{15}{|c|}{$\begin{array}{l}\text { NDT }=\text { not determined. Sample consisted of large rocks. } \\
\text { ND - non-detect } \\
\text { NS - not sampled } \\
* \text { the laboratory reporting is used in place of non-detect values } \\
* * \text {-no standard deviation for samples where }<5 \mathrm{mg} / \mathrm{kg} \text { IDL was used in calculations. } \\
* * * \text { - concentration determined gravimetrically as described in the text. }\end{array}$} \\
\hline
\end{tabular}


Table B3. Background 3 Dry Sieve

\begin{tabular}{|c|c|c|c|c|c|c|c|c|c|c|c|c|c|c|}
\hline \multirow[t]{2}{*}{ Separation Procedure } & \multicolumn{14}{|c|}{ Metals (mg/kg) } \\
\hline & $\mathrm{Pb}$ & $\mathrm{Cr}$ & $\mathrm{Cu}$ & $\mathrm{Ni}$ & $\mathrm{Zn}$ & $\mathrm{Fe}$ & $\mathrm{Mn}$ & Mo & $\mathrm{V}$ & $\mathrm{Sb}$ & W & As & $\mathrm{Ca}$ & $\mathrm{U} * * *$ \\
\hline DS_>4_BGGEL_3 rep. 1 & NDT & NDT & NDT & NDT & NDT & NDT & NDT & NDT & NDT & NDT & NDT & NDT & NS & \multirow{3}{*}{$<5 *$} \\
\hline DS_>4_BGGEL_3 rep. 2 & NDT & NDT & NDT & NDT & NDT & NDT & NDT & NDT & NDT & NDT & NDT & NDT & NS & \\
\hline DS_>4_BGGEL_3 rep. 3 & NDT & NDT & NDT & NDT & NDT & NDT & NDT & NDT & NDT & NDT & NDT & NDT & NS & \\
\hline \multicolumn{15}{|l|}{ Average } \\
\hline \multicolumn{15}{|l|}{ St dev } \\
\hline \multicolumn{15}{|l|}{$\%$ St Dev } \\
\hline DS_>10_BGGEL_3 rep. 1 & $<5 *$ & $<5 *$ & $<5 *$ & 48.20 & 82.58 & 30520.00 & 1141.00 & $<5 *$ & 72.90 & $<5 *$ & $<5 *$ & $<5 *$ & NS & $<5 *$ \\
\hline DS_>10_BGGEL_3 rep. 2 & $<5$ & $<5$ & $<5$ & 11.98 & 22.16 & 7789.00 & 251.80 & $<5$ & 18.52 & $<5$ & $<5$ & $<5$ & NS & $<5$ \\
\hline DS_>10_BGGEL_3 rep. 3 & $<5$ & $<5$ & $<5$ & 10.68 & 18.65 & 6783.00 & 235.10 & $<5$ & 16.51 & $<5$ & $<5$ & $<5$ & NS & $<5$ \\
\hline Average & $<5$ & $<5$ & $<5$ & 23.62 & 41.13 & 15030.67 & 542.63 & $<5$ & 35.98 & $<5$ & $<5$ & $<5$ & & $<5$ \\
\hline St dev & $* *$ & $* *$ & $* *$ & 21.30 & 35.94 & 13423.58 & 518.27 & $* *$ & 31.99 & $* *$ & $* *$ & $* *$ & & $* *$ \\
\hline \% St Dev & $\star *$ & $* *$ & $* *$ & 90.16 & 87.38 & 89.31 & 95.51 & $* *$ & 88.93 & $* *$ & $* *$ & $* *$ & & $* *$ \\
\hline DS_>50_BGGEL_3 rep. 1 & $<5 *$ & 10.55 & $<5 *$ & 12.43 & 22.54 & 7751.00 & 257.30 & $<5 *$ & 18.61 & $<5 *$ & $<5 *$ & $<5 *$ & NS & $<5 *$ \\
\hline DS_>50_BGGEL_3 rep. 2 & $<5$ & 10.77 & $<5$ & 12.80 & 23.89 & 7884.00 & 258.70 & $<5$ & 20.12 & $<5$ & $<5$ & $<5$ & NS & $<5$ \\
\hline DS_>50_BGGEL_3 rep. 3 & $<5$ & 10.69 & $<5$ & 12.60 & 24.15 & 8019.00 & 264.80 & $<5$ & 19.48 & $<5$ & $<5$ & $<5$ & NS & $<5$ \\
\hline Average & $<5$ & 10.67 & $<5$ & 12.61 & 23.53 & 7884.67 & 260.27 & $<5$ & 19.40 & $<5$ & $<5$ & $<5$ & & $<5$ \\
\hline St dev & $* *$ & 0.11 & $* *$ & 0.19 & 0.86 & 134.00 & 3.99 & $* *$ & 0.76 & $* *$ & $* *$ & $* *$ & & $* *$ \\
\hline \% St Dev & $* *$ & 1.04 & $* *$ & 1.47 & 3.67 & 1.70 & 1.53 & $* *$ & 3.91 & $* *$ & $* *$ & $* *$ & & $* *$ \\
\hline DS_<50_BGGEL_3 rep. 1 & $<5 *$ & $<5 *$ & $<5 *$ & $<5 *$ & 17.04 & 5302.00 & 163.00 & $<5 *$ & 14.13 & $<5 *$ & $<5 *$ & $<5 *$ & NS & $<5 *$ \\
\hline DS_<50_BGGEL_3 rep. 2 & $<5$ & $<5$ & $<5$ & $<5$ & 17.36 & 5539.00 & 163.10 & $<5$ & 14.23 & $<5$ & $<5$ & $<5$ & NS & $<5$ \\
\hline DS_<50_BGGEL_3 rep. 3 & $<5$ & $<5$ & $<5$ & $<5$ & 17.43 & 5488.00 & 160.80 & $<5$ & 14.28 & $<5$ & $<5$ & $<5$ & NS & $<5$ \\
\hline Average & $<5$ & $<5$ & $<5$ & $<5$ & 17.28 & 5443.00 & 162.30 & $<5$ & 14.21 & $<5$ & $<5$ & $<5$ & & $<5$ \\
\hline St dev & $* *$ & $* *$ & $* *$ & $* *$ & 0.21 & 124.74 & 1.30 & ** & 0.08 & ** & $* *$ & ** & & ** \\
\hline \% St Dev & $* *$ & $* *$ & $* *$ & $* *$ & 1.20 & 2.29 & 0.80 & $* *$ & 0.54 & $* *$ & $* *$ & $* *$ & & $* *$ \\
\hline \multicolumn{15}{|c|}{$\begin{array}{l}\text { NDT = not determined. Sample consisted of large rocks. } \\
\text { ND - non-detect } \\
\text { NS - not sampled } \\
\text { *the laboratory reporting is used in place of non-detect }\end{array}$} \\
\hline
\end{tabular}


Table B4. Background 4 Dry Sieve

\begin{tabular}{|c|c|c|c|c|c|c|c|c|c|c|c|c|c|c|}
\hline \multirow[t]{2}{*}{ Separation Procedure } & \multicolumn{14}{|c|}{ Metals (mg/kg) } \\
\hline & $\mathrm{Pb}$ & $\mathrm{Cr}$ & $\mathrm{Cu}$ & $\mathrm{Ni}$ & $\mathrm{Zn}$ & $\mathrm{Fe}$ & $\mathrm{Mn}$ & Mo & $\mathrm{V}$ & $\mathrm{Sb}$ & w & As & $\mathrm{Ca}$ & $U * * *$ \\
\hline DS_>4_BGGEL_4 rep. 1 & NDT & NDT & NDT & NDT & NDT & NDT & NDT & NDT & NDT & NDT & NDT & NDT & NS & \multirow{3}{*}{$<5 *$} \\
\hline DS_>4_BGGEL_4 rep. 2 & NDT & NDT & NDT & NDT & NDT & NDT & NDT & NDT & NDT & NDT & NDT & NDT & NS & \\
\hline DS_>4_BGGEL_4 rep. 3 & NDT & NDT & NDT & NDT & NDT & NDT & NDT & NDT & NDT & NDT & NDT & NDT & NS & \\
\hline \multicolumn{15}{|l|}{ Average } \\
\hline \multicolumn{15}{|l|}{ St dev } \\
\hline \multicolumn{15}{|l|}{$\%$ St Dev } \\
\hline DS_>10_BGGEL_4 rep. 1 & $<5 *$ & 9.60 & $<5 *$ & 10.05 & 19.32 & 6094.00 & 214.20 & $<5^{*}$ & 14.02 & $<5 *$ & $<5 *$ & $<5 *$ & NS & $<5 *$ \\
\hline DS_>10_BGGEL_4 rep. 2 & $<5$ & 10.27 & $<5$ & 11.05 & 23.26 & 6717.00 & 224.70 & $<5$ & 15.18 & $<5$ & $<5$ & $<5$ & NS & $<5$ \\
\hline DS_>10_BGGEL_4 rep. 3 & $<5$ & 10.41 & $<5$ & 10.52 & 20.68 & 6489.00 & 215.40 & $<5$ & 14.32 & $<5$ & $<5$ & $<5$ & NS & $<5$ \\
\hline Average & $<5$ & 10.09 & $<5$ & 10.54 & 21.09 & 6433.33 & 218.10 & $<5$ & 14.51 & $<5$ & $<5$ & $<5$ & & $<5$ \\
\hline St dev & $* *$ & 0.43 & $* *$ & 0.50 & 2.00 & 315.21 & 5.75 & $* *$ & 0.60 & $* *$ & $* *$ & $* *$ & & $* *$ \\
\hline$\%$ St Dev & $* *$ & 4.28 & $* *$ & 4.75 & 9.49 & 4.90 & 2.64 & $* *$ & 4.15 & $* *$ & $* *$ & $* *$ & & $* *$ \\
\hline DS_>50_BGGEL_4 rep. 1 & $<5^{*}$ & $<5 *$ & $<5^{*}$ & 10.21 & 22.27 & 6702.00 & 204.50 & $<5^{*}$ & 15.19 & $<5^{*}$ & $<5 *$ & $<5^{*}$ & NS & $<5 *$ \\
\hline DS_>50_BGGEL_4 rep. 2 & $<5$ & $<5$ & $<5$ & 10.10 & 21.44 & 6810.00 & 200.90 & $<5$ & 15.01 & $<5$ & $<5$ & $<5$ & NS & $<5$ \\
\hline DS_>50_BGGEL_4 rep. 3 & $<5$ & $<5$ & $<5$ & ND & 20.63 & 6376.00 & 206.30 & $<5$ & 13.56 & $<5$ & $<5$ & $<5$ & NS & $<5$ \\
\hline Average & $<5$ & $<5$ & $<5$ & 10.16 & 21.45 & 6629.33 & 203.90 & $<5$ & 14.59 & $<5$ & $<5$ & $<5$ & & $<5$ \\
\hline St dev & $* *$ & $* *$ & $* *$ & 0.08 & 0.82 & 225.94 & 2.75 & $* *$ & 0.89 & $* *$ & $* *$ & $* *$ & & $* *$ \\
\hline$\%$ St Dev & $* *$ & ** & ** & 0.77 & 3.82 & 3.41 & 1.35 & ** & 6.13 & ** & ** & ** & & $* *$ \\
\hline DS_<50_BGGEL_4 rep. 1 & $<5^{*}$ & $<5 *$ & $<5^{*}$ & $<5 *$ & 19.26 & 5285.00 & 155.40 & $<5 *$ & 11.89 & $<5^{*}$ & $<5 *$ & $<5^{*}$ & NS & $<5^{*}$ \\
\hline DS_<50_BGGEL_4 rep. 2 & $<5$ & $<5$ & $<5$ & $<5$ & 19.28 & 5477.00 & 155.60 & $<5$ & 11.85 & $<5$ & $<5$ & $<5$ & NS & $<5$ \\
\hline DS_<50_BGGEL_4 rep. 3 & $<5$ & $<5$ & $<5$ & $<5$ & 19.31 & 5005.00 & 154.90 & $<5$ & 11.43 & $<5$ & $<5$ & $<5$ & NS & $<5$ \\
\hline Average & $<5$ & $<5$ & $<5$ & $<5$ & 19.28 & 5255.67 & 155.30 & $<5$ & 11.72 & $<5$ & $<5$ & $<5$ & & $<5$ \\
\hline St dev & $* *$ & ** & $* *$ & $* *$ & 0.03 & 237.36 & 0.36 & $* *$ & 0.25 & $* *$ & $* *$ & $* *$ & & $* *$ \\
\hline$\%$ St Dev & $* *$ & $* *$ & $* *$ & $* *$ & 0.13 & 4.52 & 0.23 & $* *$ & 2.17 & $* *$ & $* *$ & $* *$ & & $* *$ \\
\hline \multicolumn{15}{|c|}{$\begin{array}{l}\text { NDT = not determined. Sample consisted of large rocks. } \\
\text { ND - non-detect } \\
\text { NS - not sampled }\end{array}$} \\
\hline
\end{tabular}


Table B5. Catch Box 1 Dry Sieve

\begin{tabular}{|c|c|c|c|c|c|c|c|c|c|c|c|c|c|c|}
\hline \multirow[t]{2}{*}{ Separation Procedure } & \multicolumn{14}{|c|}{ Metals (mg/kg) } \\
\hline & $\mathrm{Pb}$ & $\mathrm{Cr}$ & $\mathrm{Cu}$ & $\mathrm{Ni}$ & $\mathrm{Zn}$ & $\mathrm{Fe}$ & $\mathrm{Mn}$ & Mo & $\mathrm{V}$ & $\mathrm{Sb}$ & W & As & $\mathrm{Ca}$ & $\mathrm{U} * * *$ \\
\hline DS_>4_CB_1 rep. 1 & NDT & NDT & NDT & NDT & NDT & NDT & NDT & NDT & NDT & NDT & NDT & NDT & NS & \multirow{3}{*}{$13,000.00$} \\
\hline DS_>4_CB_1 rep. 2 & NDT & NDT & NDT & NDT & NDT & NDT & NDT & NDT & NDT & NDT & NDT & NDT & NS & \\
\hline DS_>4_CB_1 rep. 3 & NDT & NDT & NDT & NDT & NDT & NDT & NDT & NDT & NDT & NDT & NDT & NDT & NS & \\
\hline \multicolumn{15}{|l|}{ Average } \\
\hline \multicolumn{15}{|l|}{ St dev } \\
\hline \multicolumn{15}{|l|}{$\%$ St Dev } \\
\hline DS_>10_CB_1 rep. 1 & $<5 *$ & $<5 *$ & $<5 *$ & $<5 *$ & 19.99 & 5498.00 & 127.80 & $<5 *$ & 14.44 & $<5 *$ & $<5 *$ & $<5 *$ & 8555.00 & 1226.00 \\
\hline DS_>10_CB_1 rep. 2 & $<5$ & $<5$ & $<5$ & $<5$ & 19.15 & 5405.00 & 126.00 & $<5$ & 13.60 & $<5$ & $<5$ & $<5$ & 8719.00 & 957.60 \\
\hline DS_>10_CB_1 rep. 3 & $<5$ & $<5$ & $<5$ & $<5$ & 20.51 & 6285.00 & 138.60 & $<5$ & 15.41 & $<5$ & $<5$ & $<5$ & 8944.00 & 960.80 \\
\hline Average & $<5$ & $<5$ & $<5$ & $<5$ & 19.88 & 5729.33 & 130.80 & $<5$ & 14.48 & $<5$ & $<5$ & $<5$ & 8739.33 & 1048.13 \\
\hline St dev & $* *$ & $* *$ & $* *$ & $* *$ & 0.69 & 483.46 & 6.81 & $* *$ & 0.91 & $* *$ & $* *$ & $* *$ & 195.30 & 154.05 \\
\hline$\%$ St Dev & $* *$ & $* *$ & $* *$ & ** & 3.45 & 8.44 & 5.21 & $* *$ & 6.25 & $* *$ & $* *$ & $* *$ & 2.23 & 14.70 \\
\hline DS_>50_CB_1 rep. 1 & $<5 *$ & $<5 *$ & $<5 *$ & $<5 *$ & 21.45 & 6170.00 & 154.10 & $<5^{*}$ & 15.56 & $<5^{*}$ & $<5^{*}$ & $<5 *$ & 12020.00 & 862.90 \\
\hline DS_>50_CB_1 rep. 2 & $<5$ & $<5$ & $<5$ & $<5$ & 22.43 & 6761.00 & 156.70 & $<5$ & 17.57 & $<5$ & $<5$ & $<5$ & 11450.00 & 879.80 \\
\hline DS_>50_CB_1 rep. 3 & $<5$ & $<5$ & 10.15 & $<5$ & 23.59 & 7277.00 & 163.20 & $<5$ & 18.29 & $<5$ & $<5$ & $<5$ & 11990.00 & 851.40 \\
\hline Average & $<5$ & $<5$ & 10.15 & $<5$ & 22.49 & 6736.00 & 158.00 & $<5$ & 17.14 & $<5$ & $<5$ & $<5$ & 11820.00 & 864.70 \\
\hline St dev & $* *$ & $* *$ & $* *$ & $* *$ & 1.07 & 553.92 & 4.69 & $* *$ & 1.41 & $* *$ & $* *$ & $* *$ & 320.78 & 14.29 \\
\hline$\%$ St Dev & ** & $* *$ & $* *$ & ** & 4.76 & 8.22 & 2.97 & ** & 8.25 & ** & $* *$ & ** & 2.71 & 1.65 \\
\hline DS_<50_CB_1 rep. 1 & $<5^{*}$ & 11.50 & 17.83 & 10.57 & 38.18 & 10530.00 & 265.80 & $<5^{*}$ & 29.37 & $<5^{*}$ & $<5 *$ & $<5^{*}$ & 23870.00 & 1722.00 \\
\hline DS_<50_CB_1 rep. 2 & $<5$ & 10.78 & 17.61 & $<5$ & 34.75 & 9414.00 & 246.20 & $<5$ & 28.21 & $<5$ & $<5$ & $<5$ & 23920.00 & 1700.00 \\
\hline DS_<50_CB_1 rep. 3 & $<5$ & 12.76 & 19.18 & 10.85 & 40.29 & 11340.00 & 276.10 & $<5$ & 31.73 & $<5$ & $<5$ & $<5$ & 23980.00 & 1635.00 \\
\hline Average & $<5$ & 11.68 & 18.21 & 10.71 & 37.74 & 10428.00 & 262.70 & $<5$ & 29.77 & $<5$ & $<5$ & $<5$ & 23923.33 & 1685.67 \\
\hline St dev & $* *$ & 1.00 & 0.85 & 0.20 & 2.80 & 967.04 & 15.19 & $* *$ & 1.79 & $* *$ & $* *$ & $* *$ & 55.08 & 45.24 \\
\hline$\%$ St Dev & $* *$ & 8.58 & 4.67 & 1.85 & 7.41 & 9.27 & 5.78 & $* *$ & 6.03 & $* *$ & $* *$ & $* *$ & 0.23 & 2.68 \\
\hline \multicolumn{15}{|c|}{$\begin{array}{l}\text { NDT = not determined. Sample consisted of large rocks. } \\
\text { ND - non-detect } \\
\text { NS - not sampled }\end{array}$} \\
\hline
\end{tabular}


Table B6. Catch Box soil masses, DU mass, and DU \% of total by size fraction as determined by dry sieve separation.

\begin{tabular}{|c|c|c|c|c|c|c|c|c|c|c|c|c|c|}
\hline \multirow{2}{*}{$\begin{array}{l}\text { Size Frac- } \\
\text { tion }\end{array}$} & \multicolumn{5}{|c|}{ Soil Mass (kg) } & \multicolumn{5}{|c|}{$\mathrm{Mg}$ of DU } & \multicolumn{3}{|c|}{$\%$ Total DU per Fraction } \\
\hline & CB 1 & CB 2 & CB 3 & Avg & stdev & CB 1 & CB 2 & CB 3 & Avg & stdev & CB 1 & CB 2 & CB3 \\
\hline$>4.76 \mathrm{~mm}$ & 0.13 & 0.15 & 0.14 & 0.14 & 0.01 & 1625.00 & 750.00 & 1215.00 & 1196.67 & 10.59 & $26.41 \%$ & $11.46 \%$ & $6.63 \%$ \\
\hline $\begin{array}{l}<4.76 \mathrm{~mm} \\
\text { to } \\
>2.00 \mathrm{~mm}\end{array}$ & 1.30 & 1.70 & 2.00 & 1.67 & 0.35 & 1362.57 & 1924.96 & 8880.00 & 4055.84 & 181.08 & $22.15 \%$ & $29.42 \%$ & $48.47 \%$ \\
\hline $\begin{array}{l}<2.00 \mathrm{~mm} \\
\text { to }>0.30 \\
\mathrm{~mm}\end{array}$ & 2.10 & 2.15 & 1.90 & 2.05 & 0.13 & 1815.87 & 1934.53 & 6506.42 & 3385.61 & 14.60 & $29.52 \%$ & $28.04 \%$ & $35.51 \%$ \\
\hline$<0.30 \mathrm{~mm}$ & 0.80 & 0.90 & 0.90 & 0.87 & 0.06 & 1348.54 & 2034.00 & 1720.17 & 1700.90 & 7.76 & $21.92 \%$ & $31.08 \%$ & $9.39 \%$ \\
\hline Total & 4.33 & 4.90 & 4.94 & & & 6151.98 & 6543.49 & 18321.60 & $10,339.02$ & & & & \\
\hline
\end{tabular}


Table B7. Catch Box 2 Dry Sieve

\begin{tabular}{|c|c|c|c|c|c|c|c|c|c|c|c|c|c|c|}
\hline Separation Procedure & \multicolumn{14}{|c|}{ Metals (mg/kg) } \\
\hline$(\mathrm{ppm})$ & $\mathrm{Pb}$ & $\mathrm{Cr}$ & $\mathrm{Cu}$ & $\mathrm{Ni}$ & $\mathrm{Zn}$ & $\mathrm{Fe}$ & $\mathrm{Mn}$ & Mo & $\mathrm{V}$ & $\mathrm{Sb}$ & W & As & $\mathrm{Ca}$ & $\mathrm{U} * * *$ \\
\hline DS_>4_CB_2 rep.1 & NDT & NDT & NDT & NDT & NDT & NDT & NDT & NDT & NDT & NDT & NDT & NDT & NS & \multirow{3}{*}{$5,000.00$} \\
\hline DS_>4_CB_2 rep. 2 & NDT & NDT & NDT & NDT & NDT & NDT & NDT & NDT & NDT & NDT & NDT & NDT & NS & \\
\hline DS_>4_CB_2 rep. 3 & NDT & NDT & NDT & NDT & NDT & NDT & NDT & NDT & NDT & NDT & NDT & NDT & NS & \\
\hline \multicolumn{15}{|l|}{ Average } \\
\hline \multicolumn{15}{|l|}{ St dev } \\
\hline \multicolumn{15}{|l|}{$\%$ St Dev } \\
\hline DS_>10_CB_2 rep.1 & $<5 *$ & $<5 *$ & 10.61 & $<5 *$ & 26.38 & 6698.00 & 153.50 & $<5 *$ & 18.21 & $<5 *$ & $<5^{*}$ & $<5 *$ & NS & 1119.00 \\
\hline DS_>10_CB_2 rep. 2 & $<5$ & $<5$ & 10.42 & $<5$ & 28.15 & 7222.00 & 161.50 & $<5$ & 19.52 & $<5$ & $<5$ & $<5$ & NS & 1153.00 \\
\hline DS_>10_CB_2 rep. 3 & $<5$ & $<5$ & 10.21 & $<5$ & 25.96 & 6494.00 & 151.70 & $<5$ & 17.82 & $<5$ & $<5$ & $<5$ & NS & 1125.00 \\
\hline Average & $<5$ & $<5$ & 10.41 & $<5$ & 26.83 & 6804.67 & 155.57 & $<5$ & 18.52 & $<5$ & $<5$ & $<5$ & NS & 1132.33 \\
\hline St dev & ** & $* *$ & 0.20 & ** & 1.16 & 375.54 & 5.22 & ** & 0.89 & ** & $\star *$ & $* *$ & & 18.15 \\
\hline$\%$ St Dev & ** & $* *$ & 1.92 & $* *$ & 4.33 & 5.52 & 3.35 & ** & 4.81 & ** & ** & $* *$ & & 1.60 \\
\hline DS_>50_CB_2 rep. 1 & $<5 *$ & $<5 *$ & 10.37 & $<5 *$ & 26.60 & 7705.00 & 179.80 & $<5 *$ & 21.42 & $<5 *$ & $<5^{*}$ & $<5^{*}$ & NS & 835.70 \\
\hline DS_>50_CB_2 rep. 2 & $<5$ & $<5$ & 10.64 & $<5$ & 28.04 & 8230.00 & 187.00 & $<5$ & 22.39 & $<5$ & $<5$ & $<5$ & NS & 869.20 \\
\hline DS_>50_CB_2 rep. 3 & $<5$ & $<5$ & 10.14 & $<5$ & 27.65 & 7581.00 & 178.70 & $<5$ & 20.63 & $<5$ & $<5$ & $<5$ & NS & 854.90 \\
\hline Average & $<5$ & $<5$ & 10.38 & $<5$ & 27.43 & 7838.67 & 181.83 & $<5$ & 21.48 & $<5$ & $<5$ & $<5$ & NS & 853.27 \\
\hline St dev & $* *$ & $* *$ & 0.25 & $* *$ & 0.74 & 344.53 & 4.51 & $* *$ & 0.88 & ** & $* *$ & $* *$ & & 16.81 \\
\hline$\%$ St Dev & ** & $* *$ & 2.41 & ** & 2.72 & 4.40 & 2.48 & ** & 4.10 & ** & ** & $* *$ & & 1.97 \\
\hline DS_<50_CB_2 rep. 1 & $<5 *$ & 13.21 & 19.94 & 12.09 & 43.60 & 11310.00 & 297.70 & $<5 *$ & 35.13 & $<5 *$ & $<5^{*}$ & $<5^{*}$ & NS & 2311.00 \\
\hline DS_<50_CB_2 rep. 2 & $<5$ & 13.60 & 19.77 & 14.24 & 46.68 & 11470.00 & 301.80 & $<5$ & 35.47 & $<5$ & $<5$ & $<5$ & NS & 2255.00 \\
\hline DS_<50_CB_2 rep. 3 & $<5$ & 14.01 & 20.12 & 12.52 & 46.04 & 11910.00 & 305.30 & $<5$ & 36.44 & $<5$ & $<5$ & $<5$ & NS & 2214.00 \\
\hline Average & $<5$ & 13.61 & 19.94 & 12.95 & 45.44 & 11563.33 & 301.60 & $<5$ & 35.68 & $<5$ & $<5$ & $<5$ & NS & 2260.00 \\
\hline St dev & ** & 0.40 & 0.18 & 1.14 & 1.63 & 310.70 & 3.80 & $* *$ & 0.68 & ** & ** & ** & & 48.69 \\
\hline \% St Dev & $* *$ & 2.94 & 0.88 & 8.79 & 3.58 & 2.69 & 1.26 & $* *$ & 1.91 & ** & $* *$ & $* *$ & & 2.15 \\
\hline \multicolumn{15}{|c|}{$\begin{array}{l}\text { NDT= not determined. Sample consisted of large rocks. } \\
\text { ND - non-detect } \\
\text { NS - not sampled } \\
\text { *the laboratory reporting is used in place of non-detect values }\end{array}$} \\
\hline
\end{tabular}


Table B8. Catch Box 3 Dry Sieve

\begin{tabular}{|c|c|c|c|c|c|c|c|c|c|c|c|c|c|c|}
\hline \multirow[t]{2}{*}{ Separation Procedure } & \multicolumn{14}{|c|}{ Metals (mg/kg) } \\
\hline & $\mathrm{Pb}$ & $\mathrm{Cr}$ & $\mathrm{Cu}$ & $\mathrm{Ni}$ & $Z n$ & $\mathrm{Fe}$ & $\mathrm{Mn}$ & Mo & V & $\mathrm{Sb}$ & W & As & $\mathrm{Ca}$ & $U * * *$ \\
\hline DS_>4_BGGEL_3 rep. 1 & NDT & NDT & NDT & NDT & NDT & NDT & NDT & NDT & NDT & NDT & NDT & NDT & NS & \multirow{3}{*}{9000.00} \\
\hline DS_>4_BGGEL_3 rep. 2 & NDT & NDT & NDT & NDT & NDT & NDT & NDT & NDT & NDT & NDT & NDT & NDT & NS & \\
\hline DS_>4_BGGEL_3 rep. 3 & NDT & NDT & NDT & NDT & NDT & NDT & NDT & NDT & NDT & NDT & NDT & NDT & NS & \\
\hline \multicolumn{15}{|l|}{ Average } \\
\hline \multicolumn{15}{|l|}{ St dev } \\
\hline \multicolumn{15}{|l|}{$\%$ St Dev } \\
\hline DS_>10_BGGEL_3 rep. 1 & $<5 *$ & $<5 *$ & $<5^{*}$ & 48.20 & 82.58 & 30520.00 & 1141.00 & $<5 *$ & 72.90 & $<5 *$ & $<5 *$ & $<5 *$ & NS & $<5 *$ \\
\hline DS_>10_BGGEL_3 rep. 2 & $<5$ & $<5$ & $<5$ & 11.98 & 22.16 & 7789.00 & 251.80 & $<5$ & 18.52 & $<5$ & $<5$ & $<5$ & NS & $<5$ \\
\hline DS_>10_BGGEL_3 rep. 3 & $<5$ & $<5$ & $<5$ & 10.68 & 18.65 & 6783.00 & 235.10 & $<5$ & 16.51 & $<5$ & $<5$ & $<5$ & NS & $<5$ \\
\hline Average & $<5$ & $<5$ & $<5$ & 23.62 & 41.13 & 15030.67 & 542.63 & $<5$ & 35.98 & $<5$ & $<5$ & $<5$ & & $<5$ \\
\hline St dev & $* *$ & $* *$ & $* *$ & 21.30 & 35.94 & 13423.58 & 518.27 & $* *$ & 31.99 & $\star *$ & $* *$ & $* *$ & & $* *$ \\
\hline \% St Dev & $* *$ & $* *$ & $* *$ & 90.16 & 87.38 & 89.31 & 95.51 & $* *$ & 88.93 & $\star *$ & $* *$ & $* *$ & & $* *$ \\
\hline DS_>50_BGGEL_3 rep. 1 & $<5 *$ & 10.55 & $<5 *$ & 12.43 & 22.54 & 7751.00 & 257.30 & $<5 *$ & 18.61 & $<5 *$ & $<5 *$ & $<5 *$ & NS & $<5 *$ \\
\hline DS_>50_BGGEL_3 rep. 2 & $<5$ & 10.77 & $<5$ & 12.80 & 23.89 & 7884.00 & 258.70 & $<5$ & 20.12 & $<5$ & $<5$ & $<5$ & NS & $<5$ \\
\hline DS_>50_BGGEL_3 rep. 3 & $<5$ & 10.69 & $<5$ & 12.60 & 24.15 & 8019.00 & 264.80 & $<5$ & 19.48 & $<5$ & $<5$ & $<5$ & NS & $<5$ \\
\hline Average & $<5$ & 10.67 & $<5$ & 12.61 & 23.53 & 7884.67 & 260.27 & $<5$ & 19.40 & $<5$ & $<5$ & $<5$ & & $<5$ \\
\hline St dev & $* *$ & 0.11 & $* *$ & 0.19 & 0.86 & 134.00 & 3.99 & $* *$ & 0.76 & $* *$ & $* *$ & $* *$ & & $* *$ \\
\hline$\%$ St Dev & $* *$ & 1.04 & $* *$ & 1.47 & 3.67 & 1.70 & 1.53 & $* *$ & 3.91 & $* *$ & $* *$ & $* *$ & & $* *$ \\
\hline DS_<50_BGGEL_3 rep. 1 & $<5 *$ & $<5 *$ & $<5^{*}$ & $<5 *$ & 17.04 & 5302.00 & 163.00 & $<5^{*}$ & 14.13 & $<5 *$ & $<5 *$ & $<5 *$ & NS & $<5 *$ \\
\hline DS_<50_BGGEL_3 rep. 2 & $<5$ & $<5$ & $<5$ & $<5$ & 17.36 & 5539.00 & 163.10 & $<5$ & 14.23 & $<5$ & $<5$ & $<5$ & NS & $<5$ \\
\hline DS_<50_BGGEL_3 rep. 3 & $<5$ & $<5$ & $<5$ & $<5$ & 17.43 & 5488.00 & 160.80 & $<5$ & 14.28 & $<5$ & $<5$ & $<5$ & NS & $<5$ \\
\hline Average & $<5$ & $<5$ & $<5$ & $<5$ & 17.28 & 5443.00 & 162.30 & $<5$ & 14.21 & $<5$ & $<5$ & $<5$ & & $<5$ \\
\hline St dev & $* *$ & $* *$ & $* *$ & $* *$ & 0.21 & 124.74 & 1.30 & $* *$ & 0.08 & $* *$ & $* *$ & $* *$ & & $* *$ \\
\hline$\%$ St Dev & $* *$ & $* *$ & $* *$ & $* *$ & 1.20 & 2.29 & 0.80 & $* *$ & 0.54 & $* *$ & $* *$ & $* *$ & & $* *$ \\
\hline $\begin{array}{l}\text { NDT = not determined. Sample } \\
\text { NS - not sampled } \\
* \text { the laboratory reporting is use } \\
* * \text {-no standard deviation for sa } \\
* * * \text { - concentration determine }\end{array}$ & $\begin{array}{l}\text { d of lar } \\
\text { he of no } \\
\text { here }\end{array}$ & $\begin{array}{l}\text { se rocks. } \\
\text { n-detect } \\
\mathrm{mg} / \mathrm{kg} \\
\text { as descr }\end{array}$ & ues & d in cal & ations. & & & & & & & & & \\
\hline
\end{tabular}


Table B9. DU Garden 1 Dry Sieve

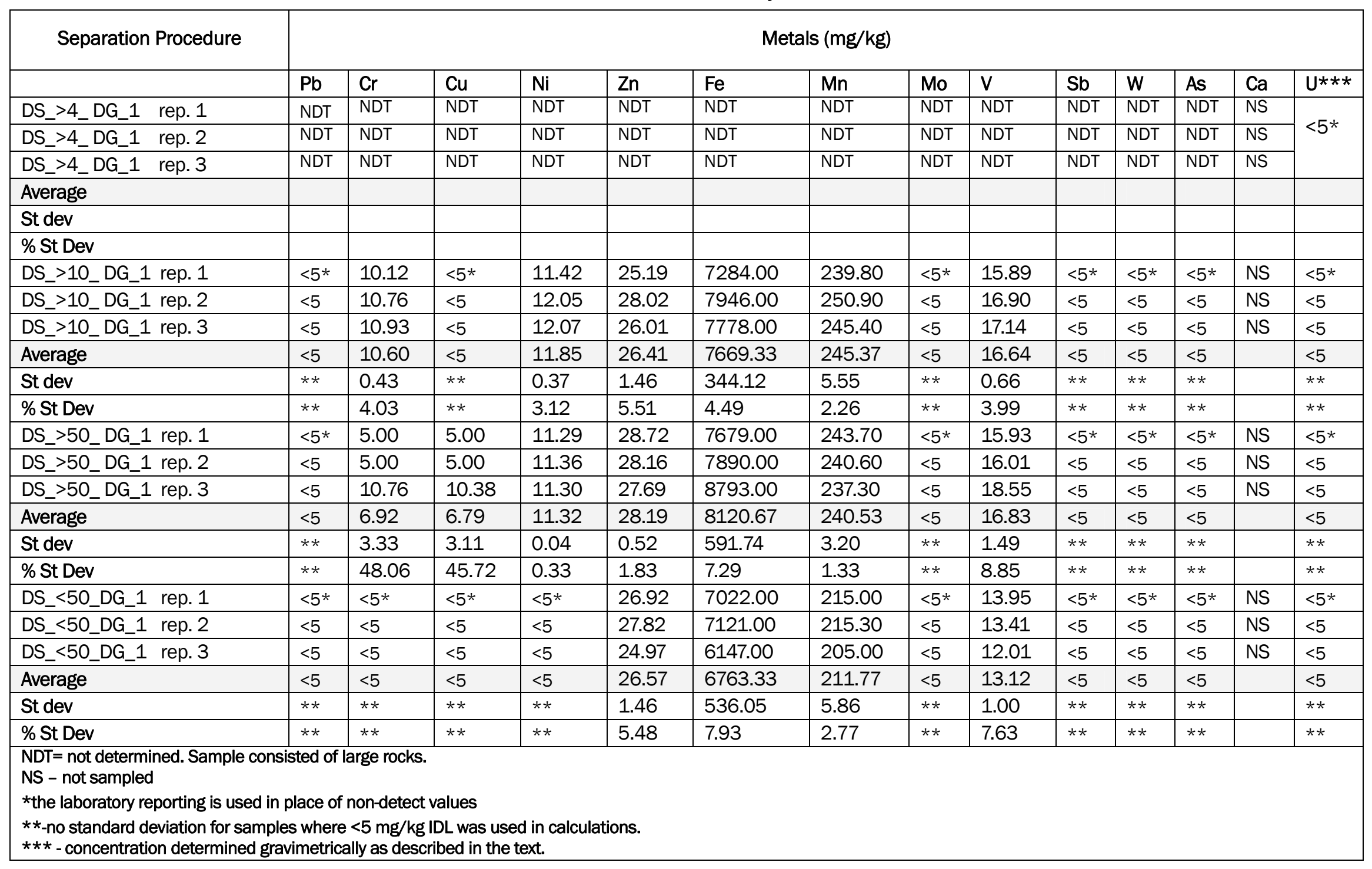


Table B10. DU Garden 2 Dry Sieve

\begin{tabular}{|c|c|c|c|c|c|c|c|c|c|c|c|c|c|c|}
\hline \multirow[t]{2}{*}{ Separation Procedure } & \multicolumn{14}{|c|}{ Metals (mg/kg) } \\
\hline & $\mathrm{Pb}$ & $\mathrm{Cr}$ & $\mathrm{Cu}$ & $\mathrm{Ni}$ & $\mathrm{Zn}$ & $\mathrm{Fe}$ & $\mathrm{Mn}$ & Mo & V & $\mathrm{Sb}$ & W & As & $\mathrm{Ca}$ & $U * * *$ \\
\hline DS_>4_DG_2 rep. 1 & NDT & NDT & NDT & NDT & NDT & NDT & NDT & NDT & NDT & NDT & NDT & NDT & NS & \multirow{3}{*}{$<5^{*}$} \\
\hline DS_>4_DG_2 rep. 2 & NDT & NDT & NDT & NDT & NDT & NDT & NDT & NDT & NDT & NDT & NDT & NDT & NS & \\
\hline DS_>4_DG_2 rep. 3 & NDT & NDT & NDT & NDT & NDT & NDT & NDT & NDT & NDT & NDT & NDT & NDT & NS & \\
\hline \multicolumn{15}{|l|}{ Average } \\
\hline \multicolumn{15}{|l|}{ St dev } \\
\hline \multicolumn{15}{|l|}{$\%$ St Dev } \\
\hline DS_>10_DG_2 rep. 1 & $<5 *$ & 14.51 & 13.48 & 15.12 & 36.78 & 9993.00 & 309.80 & $<5 *$ & 24.84 & $<5 *$ & $<5 *$ & $<5 *$ & NS & $<5 *$ \\
\hline DS_>10_DG_2 rep. 2 & $<5$ & 13.27 & 11.59 & 15.34 & 33.51 & 9761.00 & 301.90 & $<5$ & 22.25 & $<5$ & $<5$ & $<5$ & NS & $<5$ \\
\hline DS_>10_DG_2 rep. 3 & $<5$ & 13.26 & 11.41 & 15.00 & 33.39 & 9617.00 & 299.00 & $<5$ & 22.37 & $<5$ & $<5$ & $<5$ & NS & $<5$ \\
\hline Average & $<5$ & 13.68 & 12.16 & 15.15 & 34.56 & 9790.33 & 303.57 & $<5$ & 23.15 & $<5$ & $<5$ & $<5$ & & $<5$ \\
\hline St dev & $\star *$ & 0.72 & 1.15 & 0.17 & 1.92 & 189.71 & 5.59 & $* *$ & 1.46 & $* *$ & $* *$ & $* *$ & & $* *$ \\
\hline$\%$ St Dev & $\star *$ & 5.25 & 9.43 & 1.14 & 5.57 & 1.94 & 1.84 & ** & 6.31 & $* *$ & $* *$ & $* *$ & & $* *$ \\
\hline DS_>50_DG_2 rep. 1 & $<5 *$ & 10.49 & 62.82 & 14.08 & 44.16 & 8324.00 & 263.50 & $<5 *$ & 18.52 & $<5 *$ & $<5 *$ & $<5 *$ & NS & $<5 *$ \\
\hline DS_>50_DG_2 rep. 2 & $<5$ & 12.30 & 12.32 & 13.47 & 33.57 & 10040.00 & 280.80 & $<5$ & 21.54 & $<5$ & $<5$ & $<5$ & NS & $<5$ \\
\hline DS_>50_DG_2 rep. 3 & $<5$ & 11.97 & 11.81 & 13.28 & 32.23 & 9547.00 & 282.40 & $<5$ & 21.09 & $<5$ & $<5$ & $<5$ & NS & $<5$ \\
\hline Average & $<5$ & 11.59 & 28.98 & 13.61 & 36.65 & 9303.67 & 275.57 & $<5$ & 20.38 & $<5$ & $<5$ & $<5$ & & $<5$ \\
\hline St dev & $\star *$ & 0.96 & 29.30 & 0.42 & 6.54 & 883.50 & 10.48 & $* *$ & 1.63 & $* *$ & $* *$ & $* *$ & & $* *$ \\
\hline$\%$ St Dev & $* *$ & 8.32 & 101.11 & 3.07 & 17.83 & 9.50 & 3.80 & $* *$ & 7.99 & $* *$ & $* *$ & $* *$ & & $* *$ \\
\hline DS_<50_DG_2 rep. 1 & $<5 *$ & 11.87 & 12.09 & 11.97 & 33.52 & 9773.00 & 250.40 & $<5^{*}$ & 20.54 & $<5 *$ & $<5 *$ & $<5 *$ & NS & $<5 *$ \\
\hline DS_<50_DG_2 rep. 2 & $<5$ & 5.00 & 5.00 & 5.00 & 24.76 & 6451.00 & 222.00 & $<5$ & 14.26 & $<5$ & $<5$ & $<5$ & NS & $<5$ \\
\hline DS_<50_DG_2 rep. 3 & $<5$ & 5.00 & 5.00 & 5.00 & 24.88 & 6332.00 & 218.10 & $<5$ & 14.00 & $<5$ & $<5$ & $<5$ & NS & $<5$ \\
\hline Average & $<5$ & 7.29 & 7.36 & 7.32 & 27.72 & 7518.67 & 230.17 & $<5$ & 16.27 & $<5$ & $<5$ & $<5$ & & $<5$ \\
\hline St dev & $\star *$ & 3.97 & 4.09 & 4.02 & 5.02 & 1953.22 & 17.63 & $* *$ & 3.70 & $* *$ & $* *$ & $* *$ & & ** \\
\hline \% St Dev & $* *$ & 54.41 & 55.59 & 54.95 & 18.12 & 25.98 & 7.66 & $* *$ & 22.76 & $* *$ & $* *$ & $* *$ & & $* *$ \\
\hline $\begin{array}{l}\text { NDT }=\text { not determined. Sample } \\
\text { NS - not sampled } \\
* \text { the laboratory reporting is us } \\
* * \text {-no standard deviation for } \mathrm{S} \\
* * * \text { - concentration determin }\end{array}$ & \multicolumn{6}{|c|}{$\begin{array}{l}\text { NDT = not determined. Sample consisted of large rocks. } \\
\text { NS - not sampled }\end{array}$} & & & & & & & & \\
\hline
\end{tabular}


Table B11. DU Garden 3 Dry Sieve

\begin{tabular}{|c|c|c|c|c|c|c|c|c|c|c|c|c|c|c|}
\hline Separation Procedure & \multicolumn{14}{|c|}{ Metals (mg/kg) } \\
\hline (ppm) & $\mathrm{Pb}$ & $\mathrm{Cr}$ & $\mathrm{Cu}$ & $\mathrm{Ni}$ & $\mathrm{Zn}$ & $\mathrm{Fe}$ & $\mathrm{Mn}$ & Mo & V & $\mathrm{Sb}$ & W & As & $\mathrm{Ca}$ & $U * * *$ \\
\hline DS_>4_DG_3 rep. 1 & NDT & NDT & NDT & NDT & NDT & NDT & NDT & NDT & NDT & NDT & NDT & NDT & NS & \multirow{3}{*}{$<5 *$} \\
\hline DS_>4_DG_3 rep. 2 & NDT & NDT & NDT & NDT & NDT & NDT & NDT & NDT & NDT & NDT & NDT & NDT & NS & \\
\hline DS_>4_DG_3 rep. 3 & NDT & NDT & NDT & NDT & NDT & NDT & NDT & NDT & NDT & NDT & NDT & NDT & NS & \\
\hline \multicolumn{15}{|l|}{ Average } \\
\hline \multicolumn{15}{|l|}{ St dev } \\
\hline \multicolumn{15}{|l|}{$\%$ St Dev } \\
\hline DS_>10_DG_3 rep. 1 & 10.72 & 14.95 & 11.07 & 16.36 & 33.18 & 9807.00 & 311.60 & $<5 *$ & 20.57 & $<5 *$ & 40.55 & $<5 *$ & NS & $<5 *$ \\
\hline DS_>10_DG_3 rep. 2 & 5.00 & 10.18 & 5.00 & 12.00 & 23.57 & 6673.00 & 279.20 & $<5$ & 13.09 & $<5$ & 20.06 & $<5$ & NS & $<5$ \\
\hline DS_>10_DG_3 rep. 3 & 5.00 & 10.32 & 5.00 & 12.33 & 24.46 & 6781.00 & 282.60 & $<5$ & 12.95 & $<5$ & 13.65 & $<5$ & NS & $<5$ \\
\hline Average & 6.91 & 11.82 & 7.02 & 13.56 & 27.07 & 7753.67 & 291.13 & $<5$ & 15.54 & $<5$ & 24.75 & $<5$ & & $<5$ \\
\hline St dev & 3.30 & 2.71 & 3.50 & 2.43 & 5.31 & 1779.06 & 17.81 & $\star *$ & 4.36 & ** & 14.05 & ** & & ** \\
\hline \% St Dev & 47.82 & 22.97 & 49.90 & 17.90 & 19.62 & 22.94 & 6.12 & ** & 28.06 & $* *$ & 56.76 & ** & & $* *$ \\
\hline DS_>50_DG_3 rep. 1 & $<5 *$ & $<5 *$ & $<5 *$ & $<5 *$ & 20.46 & 5053.00 & 220.50 & $<5 *$ & 5.00 & $<5 *$ & 17.08 & $<5 *$ & NS & $<5 *$ \\
\hline DS_>50_DG_3 rep. 2 & $<5$ & $<5$ & $<5$ & $<5$ & 20.73 & 5132.00 & 222.70 & $<5$ & 5.00 & $<5$ & 16.58 & $<5$ & NS & $<5$ \\
\hline DS_>50_DG_3 rep. 3 & $<5$ & $<5$ & $<5$ & $<5$ & 21.98 & 5451.00 & 220.70 & $<5$ & 10.01 & $<5$ & 15.26 & $<5$ & NS & $<5$ \\
\hline Average & $<5$ & $<5$ & $<5$ & $<5$ & 21.06 & 5212.00 & 221.30 & $<5$ & 6.67 & $<5$ & 16.31 & $<5$ & & $<5$ \\
\hline St dev & ** & ** & $* *$ & ** & 0.81 & 210.72 & 1.22 & $* *$ & 2.89 & $* *$ & 0.94 & $* *$ & & $* *$ \\
\hline$\%$ St Dev & ** & ** & ** & ** & 3.85 & 4.04 & 0.55 & ** & 43.37 & $* *$ & 5.77 & ** & & ** \\
\hline DS_<50_DG_3 rep. 1 & $<5 *$ & $<5 *$ & $<5 *$ & $<5 *$ & 22.00 & 5535.00 & 193.40 & $<5 *$ & 10.85 & $<5 *$ & 11.56 & $<5 *$ & NS & $<5 *$ \\
\hline DS_<50_DG_3 rep. 2 & $<5$ & $<5$ & $<5$ & $<5$ & 22.45 & 5430.00 & 193.20 & $<5$ & 10.84 & $<5$ & 5.00 & $<5$ & NS & $<5$ \\
\hline DS_<50_DG_3 rep. 3 & $<5$ & $<5$ & $<5$ & $<5$ & 24.50 & 6164.00 & 201.90 & $<5$ & 11.39 & $<5$ & 5.00 & $<5$ & NS & $<5$ \\
\hline Average & $<5$ & $<5$ & $<5$ & $<5$ & 22.98 & 5709.67 & 196.17 & $<5$ & 11.03 & $<5$ & 7.19 & $<5$ & & $<5$ \\
\hline St dev & ** & $* *$ & $* *$ & ** & 1.33 & 396.95 & 4.97 & ** & 0.31 & $* *$ & 3.79 & ** & & ** \\
\hline \% St Dev & ** & $\star *$ & $* *$ & ** & 5.80 & 6.95 & 2.53 & $* *$ & 2.85 & $* *$ & 52.70 & ** & & ** \\
\hline \multicolumn{14}{|c|}{$\begin{array}{l}\text { NDT = not determined. Sample consisted of large rocks. } \\
\text { NS - not sampled }\end{array}$} & \\
\hline
\end{tabular}


Table B12. DU Garden 4 Dry Sieve

\begin{tabular}{|c|c|c|c|c|c|c|c|c|c|c|c|c|c|c|}
\hline \multirow[t]{2}{*}{ Separation Procedure } & \multicolumn{14}{|c|}{ Metals (mg/kg) } \\
\hline & $\mathrm{Pb}$ & $\mathrm{Cr}$ & $\mathrm{Cu}$ & $\mathrm{Ni}$ & $\mathrm{Zn}$ & $\mathrm{Fe}$ & $\mathrm{Mn}$ & Mo & V & $\mathrm{Sb}$ & W & As & $\mathrm{Ca}$ & U \\
\hline DS_>4_DG_4 rep. 1 & NDT & NDT & NDT & NDT & NDT & NDT & NDT & NDT & NDT & NDT & NDT & NDT & NS & \multirow{3}{*}{$239000.00 * * *$} \\
\hline DS_>4_DG_4 rep. 2 & NDT & NDT & NDT & NDT & NDT & NDT & NDT & NDT & NDT & NDT & NDT & NDT & NS & \\
\hline DS_>4_DG_4 rep. 3 & NDT & NDT & NDT & NDT & NDT & NDT & NDT & NDT & NDT & NDT & NDT & NDT & NS & \\
\hline \multicolumn{15}{|l|}{ Average } \\
\hline \multicolumn{15}{|l|}{ St dev } \\
\hline \multicolumn{15}{|l|}{$\%$ St Dev } \\
\hline DS_>10_DG_4 rep. 1 & 52.26 & 37.20 & 58.16 & 14.05 & 20.13 & 6012.00 & 222.00 & $<5 *$ & 55.56 & $<5 *$ & $<5 *$ & $<5 *$ & NS & 33930.00 \\
\hline DS_>10_DG_4 rep. 2 & 49.40 & 38.82 & 57.90 & 15.13 & 22.09 & 6741.00 & 227.60 & $<5$ & 55.59 & $<5$ & $<5$ & $<5$ & NS & 33420.00 \\
\hline DS_>10_DG_4 rep. 3 & 50.50 & 37.39 & 57.34 & 14.77 & 24.66 & 6519.00 & 228.80 & $<5$ & 55.95 & $<5$ & $<5$ & $<5$ & NS & 33410.00 \\
\hline Average & 50.72 & 37.80 & 57.80 & 14.65 & 22.29 & 6424.00 & 226.13 & $<5$ & 55.70 & $<5$ & $<5$ & $<5$ & & 33586.67 \\
\hline St dev & 1.44 & 0.89 & 0.42 & 0.55 & 2.27 & 373.67 & 3.63 & $* *$ & 0.22 & ** & ** & ** & & 297.38 \\
\hline$\%$ St Dev & 2.84 & 2.34 & 0.72 & 3.75 & 10.19 & 5.82 & 1.61 & $* *$ & 0.39 & ** & ** & ** & & 0.89 \\
\hline DS_>50_DG_4 rep. 1 & 44.58 & 32.08 & 50.01 & 12.70 & 21.38 & 6259.00 & 202.60 & $<5 *$ & 49.07 & $<5 *$ & $<5^{*}$ & $<5 *$ & NS & 28870.00 \\
\hline DS_>50_DG_4 rep. 2 & 47.85 & 33.74 & 52.45 & 13.34 & 22.94 & 6481.00 & 213.40 & $<5$ & 51.81 & $<5$ & $<5$ & $<5$ & NS & 30230.00 \\
\hline DS_>50_DG_4 rep. 3 & 45.95 & 32.16 & 51.48 & 12.83 & 20.09 & 5714.00 & 199.30 & $<5$ & 49.22 & $<5$ & $<5$ & $<5$ & NS & 29820.00 \\
\hline Average & 46.13 & 32.66 & 51.31 & 12.96 & 21.47 & 6151.33 & 205.10 & $<5$ & 50.03 & $<5$ & $<5$ & $<5$ & & 29640.00 \\
\hline St dev & 1.64 & 0.94 & 1.23 & 0.34 & 1.43 & 394.67 & 7.37 & ** & 1.54 & ** & ** & ** & & 697.64 \\
\hline$\%$ St Dev & 3.56 & 2.87 & 2.39 & 2.61 & 6.65 & 6.42 & 3.60 & $* *$ & 3.08 & ** & ** & ** & & 2.35 \\
\hline DS_<50_DG_4 rep. 1 & 25.79 & 22.23 & 30.89 & 12.68 & 32.50 & 8431.00 & 214.10 & $<5 *$ & 33.70 & $<5 *$ & $<5 *$ & $<5 *$ & NS & 13230.00 \\
\hline DS_<50_DG_4 rep. 2 & 25.26 & 21.62 & 30.57 & 12.49 & 28.37 & 7979.00 & 208.70 & $<5$ & 32.21 & $<5$ & $<5$ & $<5$ & NS & 13220.00 \\
\hline DS_<50_DG_4 rep. 3 & 24.73 & 21.59 & 30.85 & 13.04 & 29.94 & 8311.00 & 212.20 & $<5$ & 33.77 & $<5$ & $<5$ & $<5$ & NS & 13320.00 \\
\hline Average & 25.26 & 21.81 & 30.77 & 12.74 & 30.27 & 8240.33 & 211.67 & $<5$ & 33.23 & $<5$ & $<5$ & $<5$ & & 13256.67 \\
\hline St dev & 0.53 & 0.36 & 0.17 & 0.28 & 2.08 & 234.14 & 2.74 & ** & 0.88 & ** & ** & ** & & 55.08 \\
\hline \% St Dev & 2.10 & 1.66 & 0.57 & 2.19 & 6.89 & 2.84 & 1.29 & ** & 2.65 & ** & $* *$ & ** & & 0.42 \\
\hline \multicolumn{15}{|c|}{$\begin{array}{l}\text { NDT = not determined. Sample consisted of large rocks. } \\
\text { NS - not sampled }\end{array}$} \\
\hline
\end{tabular}


Table B13. DU Garden 5 Dry Sieve

\begin{tabular}{|c|c|c|c|c|c|c|c|c|c|c|c|c|c|c|}
\hline Separation Procedure & \multicolumn{14}{|c|}{ Metals (mg/kg) } \\
\hline & $\mathrm{Pb}$ & $\mathrm{Cr}$ & $\mathrm{Cu}$ & $\mathrm{Ni}$ & $\mathrm{Zn}$ & $\mathrm{Fe}$ & $\mathrm{Mn}$ & Mo & V & $\mathrm{Sb}$ & W & As & $\mathrm{Ca}$ & $\mathrm{U}$ \\
\hline DS_>4_DG_5 rep. 1 & NDT & NDT & NDT & NDT & NDT & NDT & NDT & NDT & NDT & NDT & NDT & NDT & NS & \multirow{3}{*}{$406000.00 * * *$} \\
\hline DS_>4_DG_5 rep. 2 & NDT & NDT & NDT & NDT & NDT & NDT & NDT & NDT & NDT & NDT & NDT & NDT & NS & \\
\hline DS_>4_DG_5 rep. 3 & NDT & NDT & NDT & NDT & NDT & NDT & NDT & NDT & NDT & NDT & NDT & NDT & NS & \\
\hline \multicolumn{15}{|l|}{ Average } \\
\hline \multicolumn{15}{|l|}{ St dev } \\
\hline \multicolumn{15}{|l|}{$\%$ St Dev } \\
\hline DS_>10_DG_5 rep. 1 & 67.10 & 72.73 & 53.71 & 21.01 & 26.78 & 7469.00 & 229.30 & $<5 *$ & 111.70 & $<5 *$ & 15.70 & $<5 *$ & NS & 42560.00 \\
\hline DS_>10_DG_5 rep. 2 & 67.58 & 77.17 & 57.40 & 22.25 & 25.69 & 7999.00 & 240.10 & $<5$ & 117.30 & $<5$ & 10.33 & $<5$ & NS & 45710.00 \\
\hline DS_>10_DG_5 rep. 3 & 65.66 & 74.25 & 54.41 & 20.95 & 25.84 & 8295.00 & 235.40 & $<5$ & 113.80 & $<5$ & $<5$ & $<5$ & NS & 43730.00 \\
\hline Average & 66.78 & 74.72 & 55.17 & 21.40 & 26.10 & 7921.00 & 234.93 & $<5$ & 114.27 & $<5$ & 13.02 & $<5$ & & 44000.00 \\
\hline St dev & 1.00 & 2.26 & 1.96 & 0.73 & 0.59 & 418.49 & 5.42 & $\star *$ & 2.83 & $* *$ & 3.80 & $* *$ & & 1592.26 \\
\hline$\%$ St Dev & 1.50 & 3.02 & 3.55 & 3.43 & 2.26 & 5.28 & 2.30 & $* *$ & 2.48 & $* *$ & 29.18 & $* *$ & & 3.62 \\
\hline DS_>50_DG_5 rep. 1 & 62.35 & 69.13 & 53.05 & 19.23 & 27.11 & 7628.00 & 217.90 & $<5 *$ & 108.00 & $<5 *$ & $<5^{*}$ & $<5 *$ & NS & 41870.00 \\
\hline DS_>50_DG_5 rep. 2 & 61.46 & 71.33 & 53.75 & 19.44 & 26.89 & 8172.00 & 233.50 & $<5$ & 108.60 & $<5$ & $<5$ & $<5$ & NS & 42310.00 \\
\hline DS_>50_DG_5 rep. 3 & 66.19 & 72.53 & 55.07 & 19.67 & 28.08 & 7948.00 & 229.80 & $<5$ & 112.70 & $<5$ & $<5$ & $<5$ & NS & 44090.00 \\
\hline Average & 63.33 & 71.00 & 53.96 & 19.45 & 27.36 & 7916.00 & 227.07 & $<5$ & 109.77 & $<5$ & $<5$ & $<5$ & & 42756.67 \\
\hline St dev & 2.51 & 1.72 & 1.03 & 0.22 & 0.63 & 273.41 & 8.15 & $* *$ & 2.56 & $* *$ & $\star *$ & $* *$ & & 1175.47 \\
\hline$\%$ St Dev & 3.97 & 2.43 & 1.90 & 1.13 & 2.31 & 3.45 & 3.59 & ** & 2.33 & $* *$ & $\star *$ & $* *$ & & 2.75 \\
\hline DS_<50_DG_5 rep. 1 & 28.53 & 32.29 & 26.12 & 13.95 & 26.70 & 7802.00 & 200.30 & $<5^{*}$ & 51.73 & $<5 *$ & $<5 *$ & $<5 *$ & NS & 16510.00 \\
\hline DS_<50_DG_5 rep. 2 & 27.43 & 32.95 & 26.82 & 13.70 & 29.14 & 7675.00 & 201.30 & $<5$ & 52.97 & $<5$ & $<5$ & $<5$ & NS & 17080.00 \\
\hline DS_<50_DG_5 rep. 3 & 26.86 & 34.29 & 26.86 & 14.27 & 28.70 & 8334.00 & 204.80 & $<5$ & 53.80 & $<5$ & $<5$ & $<5$ & NS & 16870.00 \\
\hline Average & 27.61 & 33.18 & 26.60 & 13.97 & 28.18 & 7937.00 & 202.13 & $<5$ & 52.83 & $<5$ & $<5$ & $<5$ & & 16820.00 \\
\hline St dev & 0.85 & 1.02 & 0.42 & 0.29 & 1.30 & 349.63 & 2.36 & $* *$ & 1.04 & $* *$ & ** & $* *$ & & 288.27 \\
\hline$\%$ St Dev & 3.07 & 3.07 & 1.56 & 2.04 & 4.61 & 4.41 & 1.17 & $* *$ & 1.97 & $* *$ & $* *$ & ** & & 1.71 \\
\hline \multicolumn{15}{|c|}{$\begin{array}{l}\text { NDT = not determined. Sample consisted of large rocks. } \\
\text { NS - not sampled }\end{array}$} \\
\hline
\end{tabular}


Table B14. Range 20-1 Dry Sieve"

\begin{tabular}{|c|c|c|c|c|c|c|c|c|c|c|c|c|c|c|}
\hline \multirow[t]{2}{*}{ Separation Procedure } & \multicolumn{14}{|c|}{ Metals (mg/kg) } \\
\hline & $\mathrm{Pb}$ & $\mathrm{Cr}$ & $\mathrm{Cu}$ & $\mathrm{Ni}$ & $\mathrm{Zn}$ & $\mathrm{Fe}$ & $\mathrm{Mn}$ & Mo & V & $\mathrm{Sb}$ & W & As & $\mathrm{Ca}$ & U \\
\hline DS_>4_20_1 rep. 1 & NDT & NDT & NDT & NDT & NDT & NDT & NDT & NDT & NDT & NDT & NDT & NDT & NS & \multirow{3}{*}{$8,000.00 * * *$} \\
\hline DS_>4_20_1 rep. 2 & NDT & NDT & NDT & NDT & NDT & NDT & NDT & NDT & NDT & NDT & NDT & NDT & NS & \\
\hline DS_>4_20_1 rep. 3 & NDT & NDT & NDT & NDT & NDT & NDT & NDT & NDT & NDT & NDT & NDT & NDT & NS & \\
\hline \multicolumn{15}{|l|}{ Average } \\
\hline \multicolumn{15}{|l|}{ St dev } \\
\hline \multicolumn{15}{|l|}{ \% St Dev } \\
\hline DS_>10_20_1 rep. 1 & 16.83 & 21.72 & 35.48 & 14.46 & 27.29 & 8636.00 & 256.00 & $<5 *$ & 36.97 & $<5^{*}$ & $<5^{*}$ & $<5^{*}$ & 21390.00 & 6116.00 \\
\hline DS_>10_20_1 rep. 2 & 15.06 & 22.21 & 36.58 & 14.70 & 27.01 & 8595.00 & 255.90 & $<5$ & 37.02 & $<5$ & $<5$ & $<5$ & 21470.00 & 6405.00 \\
\hline DS_>10_20_1 rep. 3 & 13.41 & 21.07 & 34.15 & 14.49 & 27.47 & 8527.00 & 250.40 & $<5$ & 36.57 & $<5$ & $<5$ & $<5$ & 21800.00 & 6007.00 \\
\hline Average & 15.10 & 21.67 & 35.40 & 14.55 & 27.26 & 8586.00 & 254.10 & $<5$ & 36.85 & $<5$ & $<5$ & $<5$ & 21553.33 & 6176.00 \\
\hline St dev & 1.71 & 0.57 & 1.22 & 0.13 & 0.23 & 55.05 & 3.20 & $* *$ & 0.25 & $* *$ & $* *$ & $* *$ & 217.33 & 205.67 \\
\hline \% St Dev & 11.33 & 2.64 & 3.44 & 0.90 & 0.85 & 0.64 & 1.26 & $* *$ & 0.67 & $* *$ & $* *$ & $* *$ & 1.01 & 3.33 \\
\hline DS_>50_20_1 rep. 1 & 20.72 & 25.95 & 54.17 & 14.47 & 27.22 & 8938.00 & 231.60 & $<5 *$ & 47.27 & $<5^{*}$ & $<5^{*}$ & $<5 *$ & 27820.00 & 11390.00 \\
\hline DS_>50_20_1 rep. 2 & 19.09 & 24.39 & 55.10 & 13.51 & 24.67 & 7654.00 & 210.80 & $<5$ & 43.92 & $<5$ & $<5$ & $<5$ & 27460.00 & 11440.00 \\
\hline DS_>50_20_1 rep. 3 & 20.76 & 25.16 & 53.36 & 13.74 & 25.07 & 7883.00 & 234.50 & $<5$ & 45.46 & $<5$ & $<5$ & $<5$ & 28360.00 & 11810.00 \\
\hline Average & 20.19 & 25.17 & 54.21 & 13.91 & 25.65 & 8158.33 & 225.63 & $<5$ & 45.55 & $<5$ & $<5$ & $<5$ & 27880.00 & 11546.67 \\
\hline St dev & 0.95 & 0.78 & 0.87 & 0.50 & 1.37 & 684.85 & 12.93 & $* *$ & 1.68 & $* *$ & $* *$ & $* *$ & 452.99 & 229.42 \\
\hline$\%$ St Dev & 4.72 & 3.10 & 1.61 & 3.60 & 5.35 & 8.39 & 5.73 & $* *$ & 3.68 & $* *$ & $* *$ & $* *$ & 1.62 & 1.99 \\
\hline DS_<50_20_1 rep. 1 & 20.96 & 25.07 & 65.94 & 12.33 & 31.24 & 7514.00 & 207.10 & $<5 *$ & 44.19 & $<5^{*}$ & $<5^{*}$ & $<5^{*}$ & 42070.00 & 12250.00 \\
\hline DS_<50_20_1 rep. 2 & 20.70 & 26.62 & 68.27 & 12.77 & 27.34 & 7819.00 & 207.20 & $<5$ & 45.21 & $<5$ & $<5$ & $<5$ & 42470.00 & 12530.00 \\
\hline DS_<50_20_1 rep. 3 & 18.95 & 26.29 & 68.63 & 12.43 & 27.45 & 7752.00 & 205.40 & $<5$ & 45.74 & $<5$ & $<5$ & $<5$ & 43520.00 & 12320.00 \\
\hline Average & 20.20 & 25.99 & 67.61 & 12.51 & 28.68 & 7695.00 & 206.57 & $<5$ & 45.05 & $<5$ & $<5$ & $<5$ & 42686.67 & 12366.67 \\
\hline St dev & 1.09 & 0.82 & 1.46 & 0.23 & 2.22 & 160.29 & 1.01 & $* *$ & 0.79 & $* *$ & $* *$ & $* *$ & 748.89 & 145.72 \\
\hline$\%$ St Dev & 5.41 & 3.14 & 2.16 & 1.84 & 7.74 & 2.08 & 0.49 & $* *$ & 1.75 & $* *$ & $* *$ & $* *$ & 1.75 & 1.18 \\
\hline \multicolumn{15}{|c|}{$\begin{array}{l}\text { NDT = not determined. Sample consisted of large rocks. } \\
\text { NS - not sampled }\end{array}$} \\
\hline
\end{tabular}


Table B15. Range 20 soil masses, DU mass and DU \% of total by size fraction as determined by dry sieve separation.

\begin{tabular}{|c|c|c|c|c|c|c|c|c|c|}
\hline \multirow[t]{2}{*}{ Size Fraction } & \multicolumn{3}{|c|}{$\begin{array}{l}\text { Soil Mass } \\
\quad(\mathrm{Kg})\end{array}$} & \multicolumn{3}{|c|}{ Mg of DU } & \multicolumn{3}{|c|}{$\%$ Total U per Size Fraction } \\
\hline & $20-1$ & $20-2$ & $20-3$ & $\begin{array}{c}20- \\
1\end{array}$ & $\begin{array}{c}20- \\
2\end{array}$ & $\begin{array}{c}20- \\
3\end{array}$ & $\begin{array}{c}20- \\
1\end{array}$ & $\begin{array}{c}20- \\
2\end{array}$ & $\begin{array}{c}20- \\
3\end{array}$ \\
\hline$>4.76 \mathrm{~mm}$ & 1.70 & 1.80 & 2.10 & $13,600.00$ & $3,600.00$ & $10,500.00$ & $26.27 \%$ & $8.85 \%$ & $16.65 \%$ \\
\hline $\begin{array}{l}<4.76 \mathrm{~mm} \text { to } \\
>2.00 \mathrm{~mm}\end{array}$ & 1.60 & 1.15 & 1.90 & $9,881.60$ & $10,547.80$ & $33,386.80$ & $19.09 \%$ & $22.55 \%$ & $27.86 \%$ \\
\hline$<0.30 \mathrm{~mm}$ & 0.70 & 0.55 & 0.70 & $8,656.90$ & $5,876.75$ & $9,345.70$ & $16.72 \%$ & $26.27 \%$ & $21.17 \%$ \\
\hline Total & 5.70 & 4.70 & 6.15 & $51,768.40$ & $40,683.75$ & $84,616.30$ & & & \\
\hline
\end{tabular}


Table B16. Range 20-2 Dry Sieve

\begin{tabular}{|c|c|c|c|c|c|c|c|c|c|c|c|c|c|c|}
\hline Separation Procedure & \multicolumn{14}{|c|}{ Metals (mg/kg) } \\
\hline & $\mathrm{Pb}$ & $\mathrm{Cr}$ & $\mathrm{Cu}$ & $\mathrm{Ni}$ & $\mathrm{Zn}$ & $\mathrm{Fe}$ & $\mathrm{Mn}$ & Mo & $\mathrm{V}$ & $\mathrm{Sb}$ & W & As & $\mathrm{Ca}$ & $U$ \\
\hline DS_>4_20_2 rep. 1 & NDT & NDT & NDT & NDT & NDT & NDT & NDT & NDT & NDT & NDT & NDT & NDT & NS & \multirow{3}{*}{$2,000.00 * * *$} \\
\hline DS_>4_20_2 rep. 2 & NDT & NDT & NDT & NDT & NDT & NDT & NDT & NDT & NDT & NDT & NDT & NDT & NS & \\
\hline DS_>4_20_2 rep. 3 & NDT & NDT & NDT & NDT & NDT & NDT & NDT & NDT & NDT & NDT & NDT & NDT & NS & \\
\hline \multicolumn{15}{|l|}{ Average } \\
\hline \multicolumn{15}{|l|}{ St dev } \\
\hline \multicolumn{15}{|l|}{ \% St Dev } \\
\hline DS_>10_20_2 rep. 1 & 17.18 & 14.62 & 29.03 & 12.84 & 18.68 & 5251.00 & 217.40 & $<5 *$ & 29.38 & $<5 *$ & $<5^{*}$ & $<5^{*}$ & NS & 8178.00 \\
\hline DS_>10_20_2 rep. 2 & 17.44 & 16.28 & 28.83 & 13.55 & 21.38 & 6393.00 & 229.20 & $<5$ & 30.96 & $<5$ & $<5$ & $<5$ & NS & 7876.00 \\
\hline DS_>10_20_2 rep. 3 & 16.26 & 16.53 & 28.52 & 13.71 & 22.58 & 6645.00 & 232.30 & $<5$ & 30.86 & $<5$ & $<5$ & $<5$ & NS & 7873.00 \\
\hline Average & 16.96 & 15.81 & 28.79 & 13.37 & 20.88 & 6096.33 & 226.30 & $<5$ & 30.40 & $<5$ & $<5$ & $<5$ & & 7975.67 \\
\hline St dev & 0.62 & 1.04 & 0.26 & 0.46 & 2.00 & 742.84 & 7.86 & $* *$ & 0.88 & $* *$ & $* *$ & $* *$ & & 175.23 \\
\hline$\%$ St Dev & 3.66 & 6.57 & 0.89 & 3.46 & 9.57 & 12.19 & 3.47 & $* *$ & 2.91 & $* *$ & $* *$ & $* *$ & & 2.20 \\
\hline DS_>50_20_2 rep. 1 & 26.77 & 18.89 & 40.91 & 10.41 & 18.98 & 5249.00 & 219.10 & $<5^{*}$ & 35.64 & $<5^{*}$ & $<5 *$ & $<5 *$ & NS & 14140.00 \\
\hline DS_>50_20_2 rep. 2 & 25.62 & 20.73 & 44.22 & 12.14 & 21.93 & 6067.00 & 229.30 & $<5$ & 37.62 & $<5$ & $<5$ & $<5$ & NS & 14370.00 \\
\hline DS_>50_20_2 rep. 3 & 28.33 & 19.36 & 43.45 & 11.18 & 19.43 & 5343.00 & 218.50 & $<5$ & 36.23 & $<5$ & $<5$ & $<5$ & NS & 14530.00 \\
\hline Average & 26.91 & 19.66 & 42.86 & 11.24 & 20.11 & 5553.00 & 222.30 & $<5$ & 36.50 & $<5$ & $<5$ & $<5$ & & 14346.67 \\
\hline St dev & 1.36 & 0.96 & 1.73 & 0.87 & 1.59 & 447.61 & 6.07 & $* *$ & 1.02 & $* *$ & $* *$ & $* *$ & & 196.04 \\
\hline$\%$ St Dev & 5.06 & 4.86 & 4.04 & 7.71 & 7.90 & 8.06 & 2.73 & ** & 2.79 & ** & ** & ** & & 1.37 \\
\hline DS_<50_20_2 rep.1 & 31.83 & 23.69 & 70.89 & 11.47 & 22.67 & 5434.00 & 196.50 & $<5^{*}$ & 43.16 & $<5^{*}$ & $<5^{*}$ & $<5^{*}$ & 19300.00 & 19300.00 \\
\hline DS_<50_20_2 rep. 2 & 31.53 & 23.70 & 70.60 & 11.19 & 21.05 & 5315.00 & 199.00 & $<5$ & 43.20 & $<5$ & $<5$ & $<5$ & 19410.00 & 19410.00 \\
\hline DS_<50_20_2 rep. 3 & 33.87 & 25.46 & 72.44 & 12.33 & 24.13 & 6044.00 & 209.30 & $<5$ & 44.45 & $<5$ & $<5$ & $<5$ & 19570.00 & 19570.00 \\
\hline Average & 32.41 & 24.28 & 71.31 & 11.66 & 22.62 & 5597.67 & 201.60 & $<5$ & 43.60 & $<5$ & $<5$ & $<5$ & 19426.67 & 19426.67 \\
\hline St dev & 1.27 & 1.02 & 0.99 & 0.59 & 1.54 & 391.09 & 6.78 & $* *$ & 0.73 & $* *$ & $* *$ & $* *$ & 135.77 & 135.77 \\
\hline \% St Dev & 3.93 & 4.20 & 1.39 & 5.09 & 6.81 & 6.99 & 3.37 & $* *$ & 1.68 & $* *$ & $* *$ & $* *$ & 0.70 & 0.70 \\
\hline \multicolumn{15}{|c|}{$\begin{array}{l}\text { NDT = not determined. Sample consisted of large rocks. } \\
\text { NS - not sampled } \\
* \text { the laboratory reporting is used in place of non-detect values } \\
* * \text {-no standard deviation for samples where }<5 \mathrm{mg} / \mathrm{kg} \text { IDL was used in calculations. } \\
* * * \text { - concentration determined gravimetrically as described in the text. }\end{array}$} \\
\hline
\end{tabular}


Table B17. Range 20-3 Dry Sieve

\begin{tabular}{|c|c|c|c|c|c|c|c|c|c|c|c|c|c|c|}
\hline Separation Procedure & \multicolumn{14}{|c|}{ Metals (mg/kg) } \\
\hline & $\mathrm{Pb}$ & $\mathrm{Cr}$ & $\mathrm{Cu}$ & $\mathrm{Ni}$ & $\mathrm{Zn}$ & $\mathrm{Fe}$ & $\mathrm{Mn}$ & Mo & $\mathrm{V}$ & $\mathrm{Sb}$ & w & As & $\mathrm{Ca}$ & $U$ \\
\hline DS_>4_20_3 rep. 1 & NDT & NDT & NDT & NDT & NDT & NDT & NDT & NDT & NDT & NDT & NDT & NDT & NS & \multirow{3}{*}{$5,000.00 * * *$} \\
\hline DS_>4_20_3 rep. 2 & NDT & NDT & NDT & NDT & NDT & NDT & NDT & NDT & NDT & NDT & NDT & NDT & NS & \\
\hline DS_>4_20_3 rep. 3 & NDT & NDT & NDT & NDT & \begin{tabular}{|l|} 
NDT \\
\end{tabular} & \begin{tabular}{|l|} 
NDT \\
\end{tabular} & NDT & NDT & NDT & NDT & NDT & NDT & NS & \\
\hline \multicolumn{15}{|l|}{ Average } \\
\hline \multicolumn{15}{|l|}{ St dev } \\
\hline \multicolumn{15}{|l|}{ \% St Dev } \\
\hline DS_>10_20_3 rep. 1 & 18.79 & 19.79 & 32.38 & 14.66 & 28.47 & 8763.00 & 253.80 & $<5 *$ & 38.45 & $<5 *$ & $<5 *$ & $<5 *$ & NS & 9135.00 \\
\hline DS_>10_20_3 rep. 2 & 17.91 & 18.26 & 31.48 & 13.04 & 24.01 & 7119.00 & 233.00 & $<5$ & 34.47 & $<5$ & $<5$ & $<5$ & NS & 9186.00 \\
\hline DS_>10_20_3 rep. 3 & 19.92 & 17.33 & 32.77 & 12.54 & 26.15 & 6876.00 & 231.10 & $<5$ & 33.88 & $<5$ & $<5$ & $<5$ & NS & 9424.00 \\
\hline Average & 18.87 & 18.46 & 32.21 & 13.41 & 26.21 & 7586.00 & 239.30 & $<5$ & 35.60 & $<5$ & $<5$ & $<5$ & & 9248.33 \\
\hline St dev & 1.01 & 1.24 & 0.66 & 1.11 & 2.23 & 1026.53 & 12.59 & $* *$ & 2.49 & $* *$ & $* *$ & $* *$ & & 154.25 \\
\hline$\%$ St Dev & 5.34 & 6.73 & 2.05 & 8.26 & 8.51 & 13.53 & 5.26 & $* *$ & 6.98 & $* *$ & $* *$ & $* *$ & & 1.67 \\
\hline DS_>50_20_3 rep. 1 & 24.47 & 20.98 & 45.14 & 12.46 & 23.11 & 6417.00 & 211.50 & $<5 *$ & 39.06 & $<5^{*}$ & $<5^{*}$ & $<5^{*}$ & NS & 14860.00 \\
\hline DS_>50_20_3 rep. 2 & 27.67 & 21.48 & 45.74 & 12.97 & 24.80 & 6807.00 & 226.60 & $<5$ & 40.65 & $<5$ & $<5$ & $<5$ & NS & 15000.00 \\
\hline DS_>50_20_3 rep. 3 & 28.27 & 20.89 & 45.82 & 12.90 & 25.00 & 6813.00 & 217.50 & $<5$ & 40.74 & $<5$ & $<5$ & $<5$ & NS & 14920.00 \\
\hline Average & 26.80 & 21.12 & 45.57 & 12.78 & 24.30 & 6679.00 & 218.53 & $<5$ & 40.15 & $<5$ & $<5$ & $<5$ & & 14926.67 \\
\hline St dev & 2.04 & 0.32 & 0.37 & 0.28 & 1.04 & 226.92 & 7.60 & $* *$ & 0.95 & $* *$ & $* *$ & $* *$ & & 70.24 \\
\hline$\%$ St Dev & 7.62 & 1.51 & 0.82 & 2.16 & 4.27 & 3.40 & 3.48 & ** & 2.35 & ** & ** & ** & & 0.47 \\
\hline DS_<50_20_3 rep.1 & 32.72 & 23.59 & 64.84 & 11.52 & 22.57 & 5608.00 & 196.90 & $<5 *$ & 41.75 & $<5^{*}$ & $<5^{*}$ & $<5^{*}$ & NS & 19310.00 \\
\hline DS_<50_20_3 rep. 2 & 29.55 & 24.78 & 68.74 & 12.01 & 24.28 & 6109.00 & 196.30 & $<5$ & 43.51 & $<5$ & $<5$ & $<5$ & NS & 19070.00 \\
\hline DS_<50_20_3 rep. 3 & 31.26 & 24.09 & 65.35 & 13.52 & 22.68 & 5764.00 & 196.10 & $<5$ & 42.35 & $<5$ & $<5$ & $<5$ & NS & 18840.00 \\
\hline Average & 31.18 & 24.15 & 66.31 & 12.35 & 23.18 & 5827.00 & 196.43 & $<5$ & 42.54 & $<5$ & $<5$ & $<5$ & & 19073.33 \\
\hline St dev & 1.59 & 0.60 & 2.12 & 1.04 & 0.96 & 256.37 & 0.42 & $* *$ & 0.89 & $* *$ & $* *$ & $* *$ & & 235.02 \\
\hline \% St Dev & 5.09 & 2.47 & 3.20 & 8.44 & 4.13 & 4.40 & 0.21 & $* *$ & 2.10 & $* *$ & $* *$ & $* *$ & & 1.23 \\
\hline \multicolumn{15}{|c|}{$\begin{array}{l}\text { NDT = not determined. Sample consisted of large rocks. } \\
\text { NS - not sampled } \\
* \text { the laboratory reporting is used in place of non-detect values } \\
* * \text {-no standard deviation for samples where }<5 \mathrm{mg} / \mathrm{kg} \text { IDL was used in calculations. } \\
* * * \text { - concentration determined gravimetrically as described in the text. }\end{array}$} \\
\hline
\end{tabular}




\section{Appendix C. Wet Sieve Separation}


Table C1. Background 1 Wet Sieve

\begin{tabular}{|c|c|c|c|c|c|c|c|c|c|c|c|c|c|c|}
\hline \multirow[t]{2}{*}{ Separation procedure } & \multicolumn{14}{|c|}{ Metals concentration $(\mathrm{mg} / \mathrm{kg})$} \\
\hline & $\mathrm{Pb}$ & $\mathrm{Cr}$ & $\mathrm{Cu}$ & $\mathrm{Ni}$ & $\mathrm{Zn}$ & $\mathrm{Fe}$ & $\mathrm{Mn}$ & Mo & $\mathrm{v}$ & $\mathrm{Sb}$ & W & As & $\mathrm{Ca}$ & $\mathrm{U}$ \\
\hline WS_>4_BGGEL_1 rep. 1 & NDT & NDT & NDT & NDT & NDT & NDT & NDT & NDT & NDT & NDT & NDT & NDT & NS & $* * *$ \\
\hline WS_>4_BGGEL_1 rep. 2 & NDT & NDT & NDT & NDT & NDT & NDT & NDT & NDT & NDT & NDT & NDT & NDT & NS & \\
\hline \multicolumn{15}{|l|}{ Average } \\
\hline \multicolumn{15}{|l|}{ St dev } \\
\hline \multicolumn{15}{|l|}{ \% St Dev } \\
\hline WS_>10_BGGEL_1 rep. 2 & $<5$ & 12.94 & $<5$ & 14.39 & 24.91 & 8159.00 & 292.20 & $<5$ & 19.52 & $<5$ & $<5$ & $<5$ & NS & $<5$ \\
\hline WS_>10_BGGEL_1 rep. 3 & $<5$ & 12.65 & $<5$ & 14.23 & 24.82 & 8098.00 & 294.50 & $<5$ & 19.31 & $<5$ & $<5$ & $<5$ & NS & $<5$ \\
\hline Average & $<5$ & 13.12 & $<5$ & 14.55 & 25.46 & 8245.00 & 296.60 & $<5$ & 19.59 & $<5$ & $<5$ & $<5$ & & $<5$ \\
\hline St dev & $* *$ & 0.59 & $* *$ & 0.42 & 1.03 & 204.08 & 5.75 & $* *$ & 0.32 & $* *$ & $* *$ & $* *$ & & $* *$ \\
\hline \% St Dev & $* *$ & 4.47 & $* *$ & 2.87 & 4.05 & 2.48 & 1.94 & $* *$ & 1.64 & $* *$ & $* *$ & $* *$ & & $* *$ \\
\hline WS_>50_BGGEL_1 rep. 1 & $<5^{\star}$ & 10.66 & $<5 *$ & 13.31 & 25.67 & 7999.00 & 314.10 & $<5 *$ & 18.49 & $<5 *$ & $<5 *$ & $<5 *$ & NS & $<5 *$ \\
\hline \% St Dev & $* *$ & 4.61 & $* *$ & 5.06 & 5.26 & 6.84 & 2.39 & * & 6.68 & * & * & * & & * \\
\hline WS_<5_BGGEL_1 rep. 1 & $<5 *$ & $<5 *$ & 14.26 & 10.11 & 32.53 & 7825.00 & 233.00 & $<5 *$ & 14.03 & $<5 *$ & $<5 *$ & $<5 *$ & NS & $<5 *$ \\
\hline 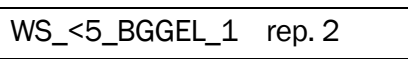 & $<5$ & $<5$ & 13.63 & $<5$ & 31.44 & 7413.00 & 225.00 & $<5$ & 13.34 & $<5$ & $<5$ & $<5$ & NS & $<5$ \\
\hline WS_<5_BGGEL_1 rep. 3 & $<5$ & $<5$ & 14.43 & 10.20 & 32.60 & 8135.00 & 233.20 & $<5$ & 14.63 & $<5$ & $<5$ & $<5$ & NS & $<5$ \\
\hline Average & $<5$ & $<5$ & 14.11 & 10.16 & 32.19 & 7791.00 & 230.40 & $<5$ & 14.00 & $<5$ & $<5$ & $<5$ & & $<5$ \\
\hline St dev & $* *$ & $* *$ & 0.42 & 0.06 & 0.65 & 362.20 & 4.68 & $* *$ & 0.65 & $* *$ & $* *$ & $* *$ & & ** \\
\hline \% St Dev & $* *$ & $* *$ & 2.99 & 0.63 & 2.02 & 4.65 & 2.03 & $* *$ & 4.61 & $* *$ & $* *$ & $* *$ & & $* *$ \\
\hline \multicolumn{15}{|c|}{$\begin{array}{l}\text { NDT= not determined. Sample consisted of large rocks. } \\
\text { NS - not sampled } \\
* \text { the laboratory reporting is used in place of non-detect values } \\
* * \text {-no standard deviation for samples where }<5 \mathrm{mg} / \mathrm{kg} \text { IDL was used in calculations. } \\
* * * \text { - concentration determined gravimetrically as described in the text. }\end{array}$} \\
\hline
\end{tabular}


Table C2. Background 2 Wet Sieve

\begin{tabular}{|c|c|c|c|c|c|c|c|c|c|c|c|c|c|c|}
\hline \multirow[t]{2}{*}{ Separation Procedure } & \multicolumn{14}{|c|}{ Metals (mg/kg) } \\
\hline & $\mathrm{Pb}$ & $\mathrm{Cr}$ & $\mathrm{Cu}$ & $\mathrm{Ni}$ & $\mathrm{Zn}$ & $\mathrm{Fe}$ & $\mathrm{Mn}$ & Mo & V & $\mathrm{Sb}$ & W & As & $\mathrm{Ca}$ & $\mathrm{U}$ \\
\hline WS_>4_BGGEL_2 rep. 1 & NDT & NDT & NDT & NDT & NDT & NDT & NDT & NDT & NDT & NDT & NDT & NDT & NS & $* * *$ \\
\hline WS_>4_BGGEL_2 rep. 2 & NDT & NDT & NDT & NDT & NDT & NDT & NDT & NDT & NDT & NDT & NDT & NDT & NS & \\
\hline WS_>4_BGGEL_2 rep. 3 & NDT & NDT & NDT & NDT & NDT & NDT & NDT & NDT & NDT & NDT & NDT & NDT & NS & \\
\hline \multicolumn{15}{|l|}{ Average } \\
\hline \multicolumn{15}{|l|}{ St dev } \\
\hline \multicolumn{15}{|l|}{ \% St Dev } \\
\hline WS_>10_BGGEL_2 rep. 1 & $<5 *$ & 15.50 & $<5 *$ & 18.11 & 29.07 & 10780.00 & 329.60 & $<5 *$ & 23.47 & $<5 *$ & $<5 *$ & $<5 *$ & NS & $<5 *$ \\
\hline WS_>10_BGGEL_2 rep. 2 & $<5$ & 15.25 & $<5$ & 16.46 & 28.60 & 10720.00 & 326.10 & $<5$ & 23.27 & $<5$ & $<5$ & $<5$ & NS & $<5$ \\
\hline WS_>10_BGGEL_2 rep. 3 & $<5$ & 14.24 & $<5$ & 15.79 & 25.87 & 9536.00 & 311.60 & $<5$ & 20.26 & $<5$ & $<5$ & $<5$ & NS & $<5$ \\
\hline Average & $<5$ & 15.00 & $<5$ & 16.79 & 27.85 & 10345.33 & 322.43 & $<5$ & 22.33 & $<5$ & $<5$ & $<5$ & & $<5$ \\
\hline St dev & $* *$ & 0.67 & ** & 1.19 & 1.73 & 701.54 & 9.54 & $* *$ & 1.80 & $* *$ & ** & $* *$ & & $* *$ \\
\hline$\%$ St Dev & $* *$ & 4.45 & $* *$ & 7.11 & 6.21 & 6.78 & 2.96 & $* *$ & 8.05 & $* *$ & $* *$ & $* *$ & & $* *$ \\
\hline WS_>50_BGGEL_2 rep.1 & 13.16 & 12.09 & 11.29 & 14.85 & 25.99 & 8662.00 & 285.30 & $<5^{*}$ & 18.15 & $<5^{*}$ & $<5^{*}$ & $<5^{*}$ & NS & $<5 *$ \\
\hline WS_>50_BGGEL_2 rep. 2 & 10.76 & 12.47 & 11.54 & 14.87 & 26.40 & 8810.00 & 277.40 & $<5$ & 18.77 & $<5$ & $<5$ & $<5$ & NS & $<5$ \\
\hline WS_>50_BGGEL_2 rep. 3 & 10.17 & 12.85 & 11.91 & 15.92 & 26.98 & 9331.00 & 285.80 & $<5$ & 19.99 & $<5$ & $<5$ & $<5$ & NS & $<5$ \\
\hline Average & 11.36 & 12.47 & 11.58 & 15.21 & 26.46 & 8934.33 & 282.83 & $<5$ & 18.97 & $<5$ & $<5$ & $<5$ & & $<5$ \\
\hline St dev & 1.58 & 0.38 & 0.31 & 0.61 & 0.50 & 351.40 & 4.71 & $* *$ & 0.94 & $* *$ & $* *$ & $* *$ & & $* *$ \\
\hline \% St Dev & 13.94 & 3.05 & 2.69 & 4.02 & 1.88 & 3.93 & 1.67 & $* *$ & 4.93 & $* *$ & $* *$ & $* *$ & & $* *$ \\
\hline WS_<0.05_BGGEL_2 rep. 1 & $<5 *$ & $<5^{*}$ & ND & $<5 *$ & 23.59 & 7373.00 & 197.00 & $<5 *$ & 14.54 & $<5 *$ & $<5 *$ & $<5 *$ & NS & $<5 *$ \\
\hline WS_<0.05_BGGEL_2 rep. 2 & $<5$ & $<5$ & 10.77 & $<5$ & 24.94 & 7730.00 & 207.10 & $<5$ & 14.83 & $<5$ & $<5$ & $<5$ & NS & $<5$ \\
\hline WS_<0.05_BGGEL_2 rep. 3 & $<5$ & $<5$ & 10.25 & $<5$ & 24.37 & 7957.00 & 207.50 & $<5$ & 15.12 & $<5$ & $<5$ & $<5$ & NS & $<5$ \\
\hline Average & $<5$ & $<5$ & 10.51 & $<5$ & 24.30 & 7686.67 & 203.87 & $<5$ & 14.83 & $<5$ & $<5$ & $<5$ & & $<5$ \\
\hline St dev & $* *$ & $* *$ & 0.37 & $* *$ & 0.68 & 294.40 & 5.95 & $* *$ & 0.29 & $* *$ & $* *$ & $* *$ & & ** \\
\hline \% St Dev & $* *$ & $* *$ & 3.50 & $* *$ & 2.79 & 3.83 & 2.92 & $* *$ & 1.96 & $* *$ & $* *$ & $* *$ & & $* *$ \\
\hline \multicolumn{15}{|c|}{$\begin{array}{l}\text { NDT }=\text { not determined. Sample consisted of large rocks. } \\
\text { NS - not sampled } \\
\text { *the laboratory reporting is used in place of non-detect values } \\
\star * \text {-no standard deviation for samples where }<5 \mathrm{mg} / \mathrm{kg} \text { IDL was used in calculations. } \\
\star * * \text { - concentration determined gravimetrically as described in the text. }\end{array}$} \\
\hline
\end{tabular}


Table C3. Background 3 Wet Sieve Separation

\begin{tabular}{|c|c|c|c|c|c|c|c|c|c|c|c|c|c|c|}
\hline \multirow[t]{2}{*}{ Separation Procedure } & \multicolumn{14}{|c|}{ Metals (mg/kg) } \\
\hline & $\mathrm{Pb}$ & $\mathrm{Cr}$ & $\mathrm{Cu}$ & $\mathrm{Ni}$ & $\mathrm{Zn}$ & $\mathrm{Fe}$ & $\mathrm{Mn}$ & Mo & $\mathrm{v}$ & $\mathrm{Sb}$ & W & As & $\mathrm{Ca}$ & U \\
\hline WS_>4_BGGEL_3 rep. 1 & NDT & NDT & NDT & NDT & NDT & NDT & NDT & NDT & NDT & NDT & NDT & NDT & NS & $* * *$ \\
\hline WS_>4_BGGEL_3 rep. 3 & NDT & NDT & NDT & NDT & NDT & NDT & NDT & NDT & NDT & NDT & NDT & NDT & NS & \\
\hline \multicolumn{15}{|l|}{ Average } \\
\hline \multicolumn{15}{|l|}{ St dev } \\
\hline WS_>10_BGGEL_3 rep. 1 & 10.83 & 17.03 & $<5 *$ & 18.32 & 27.24 & 10120.00 & 303.10 & $<5 *$ & 25.31 & $<5 *$ & 15.13 & $<5 *$ & NS & $<5 *$ \\
\hline WS_>10_BGGEL_3 rep. 2 & 13.13 & 17.84 & $<5$ & 19.68 & 29.98 & 11090.00 & 321.10 & $<5$ & 27.14 & $<5$ & 15.24 & $<5$ & NS & $<5$ \\
\hline WS_>10_BGGEL_3 rep. 3 & 11.47 & 18.79 & $<5$ & 20.05 & 30.34 & 11360.00 & 325.90 & $<5$ & 27.17 & $<5$ & 36.21 & $<5$ & NS & $<5$ \\
\hline Average & 11.81 & 17.89 & $<5$ & 19.35 & 29.19 & 10856.67 & 316.70 & $<5$ & 26.54 & $<5$ & 22.19 & $<5$ & & $<5$ \\
\hline St dev & 1.19 & 0.88 & $* *$ & 0.91 & 1.70 & 652.10 & 12.02 & ** & 1.07 & ** & 12.14 & $* *$ & & $* *$ \\
\hline$\%$ St Dev & 10.05 & 4.93 & $* *$ & 4.71 & 5.81 & 6.01 & 3.80 & $* *$ & 4.01 & $* *$ & 54.70 & $* *$ & & $* *$ \\
\hline WS_>50_BGGEL_3 rep. 1 & 8.56 & 9.29 & 10.08 & 9.35 & 22.17 & 6994.00 & 172.00 & $<5 *$ & 17.31 & $<5 *$ & 10.92 & $<5 *$ & NS & $<5 *$ \\
\hline$\%$ St Dev & 22.63 & 28.44 & 11.11 & 38.58 & 17.72 & 29.56 & 30.25 & $* *$ & 26.52 & $* *$ & 11.42 & $* *$ & & $* *$ \\
\hline WS_<50_BGGEL_3 rep. 1 & 11.01 & 12.50 & ND & 15.46 & 26.75 & 9347.00 & 272.50 & $<5^{*}$ & 21.86 & $<5 *$ & 11.03 & $<5 *$ & NS & $<5 *$ \\
\hline WS_<50_BGGEL_3 rep. 2 & 10.85 & 10.67 & ND & 13.15 & 22.92 & 7474.00 & 248.90 & $<5$ & 18.44 & $<5$ & 12.44 & $<5$ & NS & $<5$ \\
\hline WS_<50_BGGEL_3 rep. 3 & 10.64 & 8.38 & ND & 10.63 & 17.88 & 5954.00 & 220.20 & $<5$ & 14.06 & $<5$ & 14.13 & $<5$ & NS & $<5$ \\
\hline Average & 10.83 & 10.52 & & 13.08 & 22.52 & 7591.67 & 247.20 & $<5$ & 18.12 & $<5$ & 12.53 & $<5$ & & $<5$ \\
\hline St dev & \begin{tabular}{|l|}
0.19 \\
\end{tabular} & 2.06 & & 2.42 & 4.45 & 1699.56 & 26.19 & $* *$ & 3.91 & $* *$ & 1.55 & $* *$ & & $* *$ \\
\hline \% St Dev & 1.71 & 19.62 & & \begin{tabular}{|l|}
18.47 \\
\end{tabular} & 19.76 & 22.39 & 10.60 & $* *$ & 21.58 & $* *$ & 12.38 & $* *$ & & ** \\
\hline \multicolumn{15}{|c|}{$\begin{array}{l}\text { NDT }=\text { not determined. Sample consisted of large rocks. } \\
\text { NS - not sampled } \\
* \text { the laboratory reporting is used in place of non-detect values } \\
* * \text {-no standard deviation for samples where }<5 \mathrm{mg} / \mathrm{kg} \text { IDL was used in calculations. } \\
* * * \text { - concentration determined gravimetrically as described in the text. }\end{array}$} \\
\hline
\end{tabular}


Table C4. Background 4 Wet Sieve Separations

\begin{tabular}{|c|c|c|c|c|c|c|c|c|c|c|c|c|c|c|}
\hline \multirow[t]{2}{*}{ Separation Procedure } & \multicolumn{14}{|c|}{ Metals (mg/kg) } \\
\hline & $\mathrm{Pb}$ & $\mathrm{Cr}$ & $\mathrm{Cu}$ & $\mathrm{Ni}$ & $\mathrm{Zn}$ & $\mathrm{Fe}$ & $\mathrm{Mn}$ & Mo & $\mathrm{V}$ & $\mathrm{Sb}$ & W & As & $\mathrm{Ca}$ & $U$ \\
\hline WS_>4_BGGEL_4 rep. 1 & NDT & NDT & NDT & NDT & NDT & NDT & NDT & NDT & NDT & NDT & NDT & NDT & NS & $* * *$ \\
\hline WS_>4_BGGEL_4 rep. 2 & NDT & NDT & NDT & NDT & NDT & NDT & NDT & NDT & NDT & NDT & NDT & NDT & NS & \\
\hline WS_>4_BGGEL_4 rep. 3 & NDT & NDT & NDT & NDT & NDT & NDT & NDT & NDT & NDT & NDT & NDT & NDT & NS & \\
\hline \multicolumn{15}{|l|}{ Average } \\
\hline \multicolumn{15}{|l|}{ St dev } \\
\hline \multicolumn{15}{|l|}{ \% St Dev } \\
\hline WS_>10_BGGEL_4 rep. 1 & $<5^{*}$ & 16.22 & $<5^{*}$ & 16.58 & 29.72 & 9983.00 & 328.20 & $<5^{*}$ & 24.17 & $<5^{*}$ & $<5^{*}$ & $<5^{*}$ & NS & $<5 *$ \\
\hline WS_>10_BGGEL_4 rep. 2 & $<5$ & 13.91 & $<5$ & 14.83 & 26.08 & 8577.00 & 312.00 & $<5$ & 19.89 & $<5$ & $<5$ & $<5$ & NS & $<5$ \\
\hline WS_>10_BGGEL_4 rep. 3 & $<5$ & 12.65 & $<5$ & 13.98 & 24.01 & 7838.00 & 292.00 & $<5$ & 18.59 & $<5$ & $<5$ & $<5$ & NS & $<5$ \\
\hline Average & $<5$ & 14.26 & $<5$ & 15.13 & 26.60 & 8799.33 & 310.73 & $<5$ & 20.88 & $<5$ & $<5$ & $<5$ & & $<5$ \\
\hline St dev & ** & 1.81 & $* *$ & 1.33 & 2.89 & 1089.65 & 18.13 & $* *$ & 2.92 & $* *$ & ** & $* *$ & & ** \\
\hline \% St Dev & $* *$ & 12.70 & $* *$ & 8.76 & 10.87 & 12.38 & 5.84 & $* *$ & 13.98 & ** & ** & ** & & $* *$ \\
\hline WS_>50_BGGEL_4 rep. 1 & $<5 *$ & 10.19 & $<5^{*}$ & 12.33 & 22.95 & 7079.00 & 253.80 & $<5^{*}$ & 16.60 & $<5 *$ & $<5^{*}$ & $<5^{*}$ & NS & $<5 *$ \\
\hline WS_>50_BGGEL_4 rep. 2 & $<5$ & 10.85 & $<5$ & 12.99 & 24.10 & 7324.00 & 253.20 & $<5$ & 17.02 & $<5$ & $<5$ & $<5$ & NS & $<5$ \\
\hline WS_>50_BGGEL_4 rep. 3 & $<5$ & 10.93 & $<5$ & 12.92 & 25.08 & 7434.00 & 256.40 & $<5$ & 17.73 & $<5$ & $<5$ & $<5$ & NS & $<5$ \\
\hline Average & $<5$ & 10.66 & $<5$ & 12.75 & 24.04 & 7279.00 & 254.47 & $<5$ & 17.12 & $<5$ & $<5$ & $<5$ & & $<5$ \\
\hline St dev & $* *$ & 0.41 & ** & 0.36 & 1.07 & 181.73 & 1.70 & $* *$ & 0.57 & $* *$ & ** & ** & & ** \\
\hline$\%$ St Dev & $* *$ & 3.81 & ** & 2.84 & 4.43 & 2.50 & 0.67 & $* *$ & 3.34 & $* *$ & ** & $* *$ & & $* *$ \\
\hline WS_<50_BGGEL_4 rep. 1 & $<5^{*}$ & $<5 *$ & $<5^{*}$ & $<5 *$ & 20.28 & 5588.00 & 155.80 & $<5^{*}$ & 13.29 & $<5 *$ & $<5^{*}$ & $<5 *$ & NS & $<5 *$ \\
\hline WS_<50_BGGEL_4 rep. 2 & $<5$ & $<5$ & $<5$ & $<5$ & 21.34 & 5761.00 & 161.30 & $<5$ & 13.78 & $<5$ & $<5$ & $<5$ & NS & $<5$ \\
\hline WS_<50_BGGEL_4 rep. 3 & $<5$ & $<5$ & $<5$ & $<5$ & 17.89 & 5132.00 & 154.90 & $<5$ & 11.29 & $<5$ & $<5$ & $<5$ & NS & $<5$ \\
\hline Average & $<5$ & $<5$ & $<5$ & $<5$ & 19.84 & 5493.67 & 157.33 & $<5$ & 12.79 & $<5$ & $<5$ & $<5$ & & $<5$ \\
\hline St dev & $* *$ & $* *$ & $* *$ & $* *$ & 1.77 & 324.94 & 3.46 & $* *$ & 1.32 & $* *$ & $* *$ & $* *$ & & $* *$ \\
\hline$\%$ St Dev & $* *$ & $* *$ & $* *$ & $* *$ & 8.91 & 5.91 & 2.20 & $* *$ & 10.32 & $* *$ & $* *$ & $* *$ & & $* *$ \\
\hline \multicolumn{15}{|c|}{$\begin{array}{l}\text { NDT = not determined. Sample consisted of large rocks. } \\
\text { NS - not sampled } \\
* \text { the laboratory reporting is used in place of non-detect values } \\
* * \text {-no standard deviation for samples where }<5 \mathrm{mg} / \mathrm{kg} \text { IDL was used in calculations. } \\
* * * \text { - concentration determined gravimetrically as described in the text. }\end{array}$} \\
\hline
\end{tabular}


Table C5. Catch Box 1 Wet Sieve

\begin{tabular}{|c|c|c|c|c|c|c|c|c|c|c|c|c|c|c|}
\hline Separation Procedure & \multicolumn{14}{|c|}{ Metals (mg/kg) } \\
\hline & $\mathrm{Pb}$ & $\mathrm{Cr}$ & $\mathrm{Cu}$ & $\mathrm{Ni}$ & $\mathrm{Zn}$ & $\mathrm{Fe}$ & $\mathrm{Mn}$ & Mo & V & $\mathrm{Sb}$ & W & As & $\mathrm{Ca}$ & U \\
\hline WS_>4_CB_1_\#1 rep. 1 & NDT & NDT & NDT & NDT & NDT & NDT & NDT & NDT & NDT & NDT & NDT & NDT & NS & $* * *$ \\
\hline WS_>4_CB_1_\#1 rep. 2 & NDT & NDT & NDT & NDT & NDT & NDT & NDT & NDT & NDT & NDT & NDT & NDT & NS & \\
\hline WS_>4_CB_1_\#1 rep. 3 & NDT & NDT & NDT & NDT & NDT & NDT & NDT & NDT & NDT & NDT & NDT & NDT & NS & \\
\hline \multicolumn{15}{|l|}{ Average } \\
\hline \multicolumn{15}{|l|}{ St dev } \\
\hline \multicolumn{15}{|l|}{$\%$ St Dev } \\
\hline WS_>10_CB_1_\#1 rep.1 & $<5^{*}$ & $<5 *$ & $<5^{*}$ & $<5 *$ & 20.93 & 6104.00 & 128.20 & $<5 *$ & 16.45 & $<5^{*}$ & $<5 *$ & $<5 *$ & NS & 1213.00 \\
\hline WS_>10_CB_1_\#1 rep. 2 & $<5$ & $<5$ & $<5$ & $<5$ & 19.12 & 5499.00 & 117.70 & $<5$ & 14.77 & $<5$ & $<5$ & $<5$ & NS & 1183.00 \\
\hline WS_>10_CB_1_\#1 rep. 3 & $<5$ & $<5$ & $<5$ & $<5$ & 21.26 & 6284.00 & 129.60 & $<5$ & 17.00 & $<5$ & $<5$ & $<5$ & NS & 1130.00 \\
\hline Average & $<5$ & $<5$ & $<5$ & $<5$ & 20.44 & 5962.33 & 125.17 & $<5$ & 16.07 & $<5$ & $<5$ & $<5$ & & 1175.33 \\
\hline St dev & ** & ** & ** & $\star *$ & 1.15 & 411.23 & 6.50 & $* *$ & 1.16 & $\star *$ & $\star *$ & $\star *$ & & 42.03 \\
\hline$\%$ St Dev & $* *$ & $* *$ & ** & $\star *$ & 5.64 & 6.90 & 5.20 & $* *$ & 7.23 & $\star *$ & $* *$ & $* *$ & & 3.58 \\
\hline WS_>50_CB_1_\#1 rep.1 & $<5 *$ & $<5 *$ & $<5 *$ & $<5 *$ & 16.68 & 5322.00 & 113.00 & $<5 *$ & 13.04 & $<5 *$ & $<5^{*}$ & $<5 *$ & 8278.00 & 795.10 \\
\hline WS_>50_CB_1_\#1 rep. 2 & $<5$ & $<5$ & $<5$ & $<5$ & 16.48 & 4996.00 & 111.50 & $<5$ & 10.89 & $<5$ & $<5$ & $<5$ & 8873.00 & 772.50 \\
\hline WS_>50_CB_1_\#1 rep. 3 & $<5$ & $<5$ & $<5$ & $<5$ & 14.45 & 4188.00 & 100.80 & $<5$ & $<5$ & $<5$ & $<5$ & $<5$ & 8306.00 & 864.80 \\
\hline Average & $<5$ & $<5$ & $<5$ & $<5$ & 15.87 & 4835.33 & 108.43 & $<5$ & 11.97 & $<5$ & $<5$ & $<5$ & 8485.67 & 810.80 \\
\hline St dev & $* *$ & $* *$ & ** & $\star *$ & 1.23 & 583.82 & 6.65 & $* *$ & 1.52 & $* *$ & $\star *$ & $* *$ & 335.73 & 48.11 \\
\hline$\%$ St Dev & $\star *$ & $* *$ & ** & $\star *$ & 7.77 & 12.07 & 6.14 & $* *$ & 12.71 & $\star *$ & $\star *$ & $* *$ & 3.96 & 5.93 \\
\hline WS_<50_CB_1_\#1 rep. 1 & $<5 *$ & $<5 *$ & 18.82 & $<5 *$ & 33.62 & 8807.00 & 227.40 & $<5 *$ & 23.38 & $<5 *$ & $<5 *$ & $<5 *$ & 21220.00 & 1713.00 \\
\hline WS_<50_CB_1_\#1 rep. 2 & $<5$ & $<5$ & 18.03 & $<5$ & 30.41 & 7802.00 & 208.00 & $<5$ & 20.78 & $<5$ & $<5$ & $<5$ & 20370.00 & 1715.00 \\
\hline WS_<50_CB_1_\#1 rep. 3 & $<5$ & $<5$ & 19.37 & $<5$ & 34.02 & 8964.00 & 227.40 & $<5$ & 25.80 & $<5$ & $<5$ & $<5$ & 21200.00 & 1732.00 \\
\hline Average & $<5$ & $<5$ & 18.74 & $<5$ & 32.68 & 8524.33 & 220.93 & $<5$ & 23.32 & $<5$ & $<5$ & $<5$ & 20930.00 & 1720.00 \\
\hline St dev & $* *$ & $* *$ & 0.67 & $* *$ & 1.98 & 630.47 & 11.20 & $* *$ & 2.51 & $* *$ & $* *$ & ** & 485.08 & 10.44 \\
\hline$\%$ St Dev & $* *$ & $* *$ & 3.59 & $* *$ & 6.05 & 7.40 & 5.07 & $\star *$ & 10.77 & $* *$ & $* *$ & $* *$ & 2.32 & 0.61 \\
\hline WS_>4_CB_1_\#2 rep. 1 & NS & NS & NS & NS & NS & NS & NS & NS & NS & NS & NS & NS & NS & NS \\
\hline WS_>4_CB_1_\#2 rep. 2 & NS & NS & NS & NS & NS & NS & NS & NS & NS & NS & NS & NS & NS & NS \\
\hline WS_>4_CB_1_\#2 rep. 3 & NS & NS & NS & NS & NS & NS & NS & NS & NS & NS & NS & NS & NS & NS \\
\hline \multicolumn{15}{|l|}{ Average } \\
\hline \multicolumn{15}{|l|}{ St dev } \\
\hline \% St Dev & & & & & & & & & & & & & & \\
\hline
\end{tabular}




\begin{tabular}{|c|c|c|c|c|c|c|c|c|c|c|c|c|c|c|}
\hline Separation Procedure & \multicolumn{14}{|c|}{ Metals (mg/kg) } \\
\hline & $\mathrm{Pb}$ & $\mathrm{Cr}$ & $\mathrm{Cu}$ & $\mathrm{Ni}$ & $\mathrm{Zn}$ & $\mathrm{Fe}$ & $\mathrm{Mn}$ & Mo & $\mathrm{V}$ & $\mathrm{Sb}$ & W & As & $\mathrm{Ca}$ & $\mathrm{U}$ \\
\hline WS_>10_CB_1_\#2 rep.1 & $<5 *$ & $<5 *$ & $<5 *$ & $<5^{*}$ & 20.86 & 5780.00 & 129.90 & $<5 *$ & 13.93 & $<5^{*}$ & 10.79 & $<5 *$ & NS & $<5^{*}$ \\
\hline WS_>10_CB_1_\#2 rep. 2 & $<5$ & $<5$ & $<5$ & $<5$ & 14.71 & 3845.00 & 99.30 & $<5$ & 10.12 & $<5$ & 11.54 & $<5$ & NS & $<5$ \\
\hline WS_>10_CB_1_\#2 rep. 3 & $<5$ & $<5$ & $<5$ & $<5$ & 15.22 & 3931.00 & 100.40 & $<5$ & 10.18 & $<5$ & 10.81 & $<5$ & NS & $<5$ \\
\hline Average & $<5$ & $<5$ & $<5$ & $<5$ & 16.93 & 4518.67 & 109.87 & $<5$ & 11.41 & $<5$ & 11.05 & $<5$ & NS & $<5$ \\
\hline St dev & $* *$ & $* *$ & $* *$ & $* *$ & 3.41 & 1093.19 & 17.36 & $\star *$ & 2.18 & $* *$ & 0.43 & $* *$ & & $* *$ \\
\hline$\%$ St Dev & $* *$ & $* *$ & $\star *$ & $* *$ & 20.16 & 24.19 & 15.80 & $\star *$ & 19.13 & $* *$ & 3.87 & $* *$ & & $* *$ \\
\hline WS_>50_CB_1_\#2 rep.1 & $<5 *$ & $<5 *$ & $<5 *$ & $<5 *$ & 12.38 & 3264.00 & 91.51 & $<5 *$ & $<5 *$ & $<5 *$ & $<5 *$ & $<5^{*}$ & 8468.00 & 609.50 \\
\hline WS_>50_CB_1_\#2 rep. 2 & $<5$ & $<5$ & $<5$ & $<5$ & 12.16 & 3304.00 & 89.52 & $<5$ & $<5$ & $<5$ & $<5$ & $<5$ & 8666.00 & 712.00 \\
\hline WS_>50_CB_1_\#2 rep. 3 & $<5$ & $<5$ & $<5$ & $<5$ & 11.66 & 3252.00 & 87.17 & $<5$ & $<5$ & $<5$ & $<5$ & $<5$ & 8314.00 & 638.60 \\
\hline Average & $<5$ & $<5$ & $<5$ & $<5$ & 4.56 & 1882.16 & 43.15 & $<5$ & $<5$ & $<5$ & $<5$ & $<5$ & 140.01 & 72.48 \\
\hline St dev & $* *$ & $* *$ & $* *$ & $* *$ & 0.37 & 27.23 & 2.17 & $* *$ & $* *$ & $* *$ & $* *$ & $* *$ & 176.46 & 52.82 \\
\hline$\%$ St Dev & $\star *$ & $* *$ & $* *$ & $* *$ & 8.10 & 1.45 & 5.03 & $\star *$ & $* *$ & $* *$ & $\star *$ & $* *$ & 126.03 & 72.88 \\
\hline WS_<50_CB_1_\#2 rep.1 & $<5 *$ & 12.34 & 31.67 & 11.20 & 44.59 & 10940.00 & 277.00 & $<5 *$ & 30.40 & $<5^{*}$ & $<5 *$ & $<5^{*}$ & 23130.00 & 1861.00 \\
\hline WS_<50_CB_1_\#2 rep. 2 & $<5$ & 10.17 & 28.83 & 5.00 & 36.32 & 8448.00 & 238.60 & $<5$ & 23.14 & $<5$ & $<5$ & $<5$ & 22870.00 & 1854.00 \\
\hline WS_<50_CB_1_\#2 rep. 3 & $<5$ & $<5$ & 27.67 & 5.00 & 31.81 & 6901.00 & 219.40 & $<5$ & 19.43 & $<5$ & $<5$ & $<5$ & 23420.00 & 2009.00 \\
\hline Average & $<5$ & 11.26 & 29.39 & 7.07 & 37.57 & 8763.00 & 245.00 & $<5$ & 24.32 & $<5$ & $<5$ & $<5$ & 23140.00 & 1908.00 \\
\hline St dev & $* *$ & 1.53 & 2.06 & 3.58 & 6.48 & 2037.84 & 29.33 & $* *$ & 5.58 & ** & $* *$ & $* *$ & 275.14 & 87.54 \\
\hline \% St Dev & $* *$ & 13.63 & 7.00 & 50.65 & 17.25 & 23.26 & 11.97 & $* *$ & 22.94 & $* *$ & ** & ** & 1.19 & 4.59 \\
\hline WS_>4_CB_1_\#3 rep.1 & NS & NS & NS & NS & NS & NS & NS & NS & NS & NS & NS & NS & NS & NS \\
\hline WS_>4_CB_1_\#3 rep. 2 & NS & NS & NS & NS & NS & NS & NS & NS & NS & NS & NS & NS & NS & NS \\
\hline WS_>4_CB_1_\#3 rep. 3 & NS & NS & NS & NS & NS & NS & NS & NS & NS & NS & NS & NS & NS & NS \\
\hline \multicolumn{15}{|l|}{ Average } \\
\hline \multicolumn{15}{|l|}{ St dev } \\
\hline \multicolumn{15}{|l|}{$\%$ St Dev } \\
\hline WS_>10_CB_1_\#3 rep.1 & $<5 *$ & $<5 *$ & $<5 *$ & $<5 *$ & 14.79 & 4008.00 & 96.74 & $<5 *$ & 10.59 & $<5 *$ & 11.22 & $<5^{*}$ & NS & $<5 *$ \\
\hline WS_>10_CB_1_\#3 rep. 2 & $<5$ & $<5$ & $<5$ & $<5$ & 14.55 & 3921.00 & 94.11 & $<5$ & 10.24 & $<5$ & $<5$ & $<5$ & NS & $<5$ \\
\hline WS_>10_CB_1_\#3 rep. 3 & $<5$ & $<5$ & $<5$ & $<5$ & 13.73 & 3710.00 & 89.21 & $<5$ & $<5$ & $<5$ & 10.35 & $<5$ & NS & $<5$ \\
\hline Average & $<5$ & $<5$ & $<5$ & $<5$ & 14.36 & 3879.67 & 93.35 & $<5$ & 10.42 & $<5$ & 10.79 & $<5$ & NS & $<5$ \\
\hline St dev & $* *$ & $* *$ & $* *$ & $* *$ & 0.56 & 153.24 & 3.82 & $* *$ & 0.25 & $* *$ & 0.62 & $* *$ & & $* *$ \\
\hline \% St Dev & $* *$ & $* *$ & $* *$ & $* *$ & 3.87 & 3.95 & 4.09 & $* *$ & 2.38 & $* *$ & 5.70 & $* *$ & & $* *$ \\
\hline WS_>50_CB_1_\#3 rep.1 & $<5 *$ & $<5 *$ & $<5 *$ & $<5 *$ & 12.78 & 3326.00 & 85.57 & $<5 *$ & $<5 *$ & $<5 *$ & $<5 *$ & $<5 *$ & 8086.00 & 550.60 \\
\hline WS_>50_CB_1_\#3 rep. 2 & $<5$ & $<5$ & $<5$ & $<5$ & 15.13 & 4730.00 & 104.10 & $<5$ & $<5$ & $<5$ & $<5$ & $<5$ & 7872.00 & 500.40 \\
\hline
\end{tabular}




\begin{tabular}{|c|c|c|c|c|c|c|c|c|c|c|c|c|c|c|}
\hline Separation Procedure & $\mathrm{Pb}$ & $\mathrm{Cr}$ & $\mathrm{Cu}$ & $\mathrm{Ni}$ & $\mathrm{Zn}$ & $\mathrm{Fe}$ & $\mathrm{Mn}$ & Mo & V & $\mathrm{Sb}$ & w & As & $\mathrm{Ca}$ & $\mathrm{u}$ \\
\hline WS_>50_CB_1_\#3 rep. 3 & $<5$ & $<5$ & $<5$ & $<5$ & 12.38 & 3391.00 & 85.36 & $<5$ & $<5$ & $<5$ & $<5$ & $<5$ & 7710.00 & 551.20 \\
\hline St dev & $* *$ & ** & $* *$ & ** & 1.49 & 792.50 & 10.76 & ** & $* *$ & ** & ** & $* *$ & 188.60 & 29.16 \\
\hline$\%$ St Dev & ** & ** & ** & ** & 11.06 & 20.77 & 11.74 & ** & ** & ** & ** & ** & 2.39 & 5.46 \\
\hline WS_<50_CB_1_\#3 rep. 1 & $<5^{*}$ & $<5^{*}$ & 26.70 & $<5^{*}$ & 25.31 & 5815.00 & 188.10 & $<5^{*}$ & 17.55 & $<5^{*}$ & $<5^{*}$ & $<5 *$ & 21180.00 & 2394.00 \\
\hline Average & $<5$ & $<5$ & 26.40 & $<5$ & 27.27 & 6403.33 & 195.87 & $<5$ & 18.53 & $<5$ & $<5$ & $<5$ & 20906.67 & 2254.00 \\
\hline St dev & $* *$ & $* *$ & 0.68 & $* *$ & 2.53 & 698.97 & 7.75 & $* *$ & 1.03 & $* *$ & $* *$ & $* *$ & 580.46 & 148.07 \\
\hline$\%$ St Dev & ** & $* *$ & 2.58 & $* *$ & 9.29 & 10.92 & 3.96 & ** & 5.55 & ** & ** & $* *$ & 2.78 & 6.57 \\
\hline $\begin{array}{l}\text { For the Catch Box } 1 \text { soil, tripl } \\
\text { NDT = not determined. Samp } \\
\text { NS - not sampled/no sampl } \\
* \text { the laboratory reporting is } \\
* * \text {-no standard deviation for } \\
* * * \text { - concentration determir }\end{array}$ & $\begin{array}{l}\text { s were } \\
\text { nsisted } \\
\text { in plac } \\
\text { ples wh }\end{array}$ & $\begin{array}{l}\text { lone la } \\
\text { of larg } \\
\text { of non } \\
\text { ere }<5 \\
\text { rically }\end{array}$ & $\begin{array}{l}\text { d as: CBI } \\
\text { cks. } \\
\text { ect value } \\
\text { /kg IDL W } \\
\text { escribed }\end{array}$ & $\begin{array}{l}\text { s used } \\
\text { the ter }\end{array}$ & 2 , and C & $1 \# 3$. & & & & & & & & \\
\hline
\end{tabular}


Table C6. Catch Box soil masses, DU mass and DU \% of total by size fraction as determined by wet sieve separation.

\begin{tabular}{|c|c|c|c|c|c|c|c|c|c|c|c|c|c|}
\hline \multirow[t]{2}{*}{$\begin{array}{c}\text { Size } \\
\text { Fraction }\end{array}$} & \multicolumn{5}{|c|}{$\begin{array}{l}\text { Soil Mass } \\
(\mathrm{kg})\end{array}$} & \multicolumn{5}{|c|}{$\mathrm{Mg}$ of DU } & \multicolumn{3}{|c|}{ \% Total DU per Fraction } \\
\hline & CB 1 & CB 2 & CB 3 & Avg & stdev & CB 1 & CB 2 & CB 3 & Avg & stdev & CB 1 & CB 2 & CB 3 \\
\hline$>4.76 \mathrm{~mm}$ & 0.02 & 0.02 & 0.01 & 0.02 & 0.00 & 20.53 & 23.00 & 0.00 & 14.51 & 13.05 & $2.76 \%$ & $2.35 \%$ & $0.00 \%$ \\
\hline $\begin{array}{l}<4.76 \mathrm{~mm} \\
\text { to } \\
>2.00 \mathrm{~mm}\end{array}$ & 0.15 & 0.16 & 0.15 & 0.15 & 0.01 & 59.60 & 0.01 & 10.21 & 23.27 & 31.75 & $8.02 \%$ & $0.00 \%$ & $1.20 \%$ \\
\hline $\begin{array}{l}<2.00 \mathrm{~mm} \\
\text { to }>0.30 \\
\mathrm{~mm}\end{array}$ & 0.39 & 0.42 & 0.43 & 0.41 & 0.02 & 184.10 & 455.28 & 641.42 & 426.93 & 216.65 & $24.77 \%$ & $46.55 \%$ & $75.39 \%$ \\
\hline$<0.30 \mathrm{~mm}$ & 0.24 & 0.14 & 0.08 & 0.16 & 0.08 & 479.06 & 499.70 & 199.20 & 392.65 & 238.93 & $64.45 \%$ & $51.09 \%$ & $23.41 \%$ \\
\hline Total & 0.81 & 0.72 & 0.66 & 0.73 & & 743.29 & 977.99 & 850.83 & 857.37 & & & & \\
\hline
\end{tabular}


Table C7. Catch Box 2 Wet Sieve

\begin{tabular}{|c|c|c|c|c|c|c|c|c|c|c|c|c|c|c|}
\hline \multirow{2}{*}{$\begin{array}{l}\text { Separation Procedure } \\
(\mathrm{ppm})\end{array}$} & \multicolumn{14}{|c|}{ Metals (mg/kg) } \\
\hline & $\mathrm{Pb}$ & $\mathrm{Cr}$ & $\mathrm{Cu}$ & $\mathrm{Ni}$ & $\mathrm{Zn}$ & $\mathrm{Fe}$ & $\mathrm{Mn}$ & Mo & V & $\mathrm{Sb}$ & W & As & $\mathrm{Ca}$ & $\mathrm{U}$ \\
\hline WS_>4_CB_2 rep. 1 & NDT & NDT & NDT & NDT & NDT & NDT & NDT & NDT & NDT & NDT & NDT & NDT & NS & $* * *$ \\
\hline WS_>4_CB_2 rep. 2 & NDT & NDT & NDT & NDT & NDT & NDT & NDT & NDT & NDT & NDT & NDT & NDT & NS & \\
\hline WS_>4_CB_2 rep. 3 & NDT & NDT & NDT & NDT & NDT & NDT & NDT & NDT & NDT & NDT & NDT & NDT & NS & \\
\hline \multicolumn{15}{|l|}{ Average } \\
\hline \multicolumn{15}{|l|}{ St dev } \\
\hline \multicolumn{15}{|l|}{$\%$ St Dev } \\
\hline WS_>10_CB_2 rep.1 & $<5 *$ & $<5 *$ & $<5 *$ & $<5 *$ & 19.09 & 5445.00 & 129.50 & $<5 *$ & 12.14 & $<5 *$ & $<5 *$ & $<5^{*}$ & NS & $<5 *$ \\
\hline WS_>10_CB_2 rep. 2 & $<5$ & $<5$ & $<5$ & $<5$ & 19.89 & 5418.00 & 133.10 & $<5$ & 11.97 & $<5$ & $<5$ & $<5$ & NS & $<5$ \\
\hline WS_>10_CB_2 rep. 3 & $<5$ & $<5$ & $<5$ & $<5$ & 20.05 & 5684.00 & 135.10 & $<5$ & 12.64 & $<5$ & $<5$ & $<5$ & NS & $<5$ \\
\hline Average & $<5$ & $<5$ & $<5$ & $<5$ & 19.68 & 5515.67 & 132.57 & $<5$ & 12.25 & $<5$ & $<5$ & $<5$ & NS & $<5$ \\
\hline St dev & $* *$ & $* *$ & $* *$ & $* *$ & 0.51 & 146.40 & 2.84 & $* *$ & 0.35 & $* *$ & $* *$ & $* *$ & & $* *$ \\
\hline$\%$ St Dev & ** & $* *$ & $* *$ & $* *$ & 2.61 & 2.65 & 2.14 & $* *$ & 2.84 & $* *$ & $* *$ & $* *$ & & ** \\
\hline WS_>50_CB_2 rep. 1 & $<5 *$ & $<5 *$ & 11.90 & $<5 *$ & 21.28 & 5411.00 & 123.90 & $<5 *$ & 15.02 & $<5 *$ & $<5 *$ & $<5^{*}$ & NS & 1109.00 \\
\hline WS_>50_CB_2 rep. 2 & $<5$ & $<5$ & 11.53 & $<5$ & 19.50 & 5254.00 & 120.50 & $<5$ & 14.47 & $<5$ & $<5$ & $<5$ & NS & 1086.00 \\
\hline WS_>50_CB_2 rep. 3 & $<5$ & $<5$ & 11.81 & $<5$ & 21.56 & 5674.00 & 126.10 & $<5$ & 15.40 & $<5$ & $<5$ & $<5$ & NS & 1057.00 \\
\hline Average & $<5$ & $<5$ & 11.75 & $<5$ & 20.78 & 5446.33 & 123.50 & $<5$ & 14.96 & $<5$ & $<5$ & $<5$ & $<5$ & 1084.00 \\
\hline St dev & $* *$ & $* *$ & 0.19 & $* *$ & 1.12 & 212.22 & 2.82 & $* *$ & 0.47 & $\star *$ & $* *$ & $* *$ & * & 26.06 \\
\hline \% St Dev & $* *$ & $* *$ & 1.64 & $* *$ & 5.38 & 3.90 & 2.28 & $* *$ & 3.12 & $* *$ & $* *$ & $* *$ & * & 2.40 \\
\hline WS_<50_CB_2 rep.1 & 10.62 & 14.27 & 32.15 & 11.23 & 47.23 & 10750.00 & 280.70 & $<5 *$ & 34.78 & $<5 *$ & 17.10 & $<5^{*}$ & NS & 3549.00 \\
\hline WS_<50_CB_2 rep. 2 & 10.74 & 14.08 & 32.07 & 11.37 & 46.25 & 11110.00 & 283.10 & $<5$ & 35.53 & $<5$ & 15.19 & $<5$ & NS & 3541.00 \\
\hline WS_<50_CB_2 rep. 3 & 11.61 & 14.16 & 32.27 & 11.53 & 45.45 & 11230.00 & 284.40 & $<5$ & 35.74 & $<5$ & 16.09 & $<5$ & NS & 3542.00 \\
\hline Average & 10.99 & 14.17 & 32.16 & 11.38 & 46.31 & 11030.00 & 282.73 & $<5$ & 35.35 & $<5$ & 16.13 & $<5$ & & 3544.00 \\
\hline St dev & 0.54 & 0.10 & 0.10 & 0.15 & 0.89 & 249.80 & 1.88 & ** & 0.50 & $* *$ & 0.96 & $* *$ & & 4.36 \\
\hline \% St Dev & 4.92 & 0.67 & 0.31 & 1.32 & 1.93 & 2.26 & 0.66 & $* *$ & 1.43 & $* *$ & 5.93 & $* *$ & & 0.12 \\
\hline \multicolumn{15}{|c|}{$\begin{array}{l}\text { NDT = not determined. Sample consisted of large rocks. } \\
\text { NS - not sampled/no sample } \\
* \text { the laboratory reporting is used in place of non-detect values } \\
* * \text {-no standard deviation for samples where }<5 \mathrm{mg} / \mathrm{kg} \text { IDL was used in calculations. } \\
* * * \text { - concentration determined gravimetrically as described in the text. }\end{array}$} \\
\hline
\end{tabular}


Table C8. Catch Box 3 Wet Sieve

\begin{tabular}{|c|c|c|c|c|c|c|c|c|c|c|c|c|c|c|}
\hline \multirow[t]{2}{*}{ Separation Procedure } & \multicolumn{14}{|c|}{ Metals (mg/kg) } \\
\hline & $\mathrm{Pb}$ & $\mathrm{Cr}$ & $\mathrm{Cu}$ & $\mathrm{Ni}$ & $\mathrm{Zn}$ & $\mathrm{Fe}$ & $\mathrm{Mn}$ & Mo & $\mathrm{V}$ & $\mathrm{Sb}$ & $\mathrm{W}$ & As & $\mathrm{Ca}$ & $\mathrm{U}$ \\
\hline WS_>4_CB_3 rep. 1 & NDT & NDT & NDT & NDT & NDT & NDT & NDT & NDT & NDT & NDT & NDT & NDT & NS & $* * *$ \\
\hline WS_>4_CB_3 rep. 2 & NDT & NDT & NDT & NDT & NDT & NDT & NDT & NDT & NDT & NDT & NDT & NDT & NS & \\
\hline WS_>4_CB_3 rep. 3 & NDT & NDT & NDT & NDT & NDT & NDT & NDT & NDT & NDT & NDT & NDT & NDT & NS & \\
\hline \multicolumn{15}{|l|}{ Average } \\
\hline \multicolumn{15}{|l|}{ St dev } \\
\hline \multicolumn{15}{|l|}{$\%$ St Dev } \\
\hline WS_>10_CB_3 rep.1 & $<5 *$ & $<5 *$ & $<5 *$ & $<5 *$ & 21.41 & 6483.00 & 133.60 & $<5 *$ & 15.97 & $<5^{*}$ & $<5 *$ & $<5 *$ & 43.41 & 43.41 \\
\hline WS_>10_CB_3 rep. 2 & $<5$ & $<5$ & $<5$ & $<5$ & 21.24 & 6246.00 & 135.40 & $<5$ & 15.90 & $<5$ & $<5$ & $<5$ & 117.80 & 117.80 \\
\hline WS_>10_CB_3 rep. 3 & $<5$ & $<5$ & $<5$ & $<5$ & 21.54 & 6302.00 & 131.30 & $<5$ & 15.85 & $<5$ & $<5$ & $<5$ & 44.32 & 44.32 \\
\hline Average & $<5$ & $<5$ & $<5$ & $<5$ & 21.40 & 6343.67 & 133.43 & $<5$ & 15.91 & $<5$ & $<5$ & $<5$ & 68.51 & 68.51 \\
\hline St dev & $\star *$ & $\star *$ & $* *$ & $* *$ & 0.15 & 123.87 & 2.06 & $* *$ & 0.06 & $* *$ & $* *$ & $* *$ & 42.69 & 42.69 \\
\hline \% St Dev & $\star *$ & $* *$ & $* *$ & $* *$ & 0.70 & 1.95 & 1.54 & $* *$ & 0.38 & $* *$ & $* *$ & $* *$ & 62.31 & 62.31 \\
\hline WS_>18_CB_3 rep. 1 & $<5 *$ & $<5 *$ & 10.33 & $<5 *$ & 17.08 & 4681.00 & 105.30 & $<5 *$ & 15.54 & $<5 *$ & $<5 *$ & $<5 *$ & NS & 1837.00 \\
\hline WS_>18_CB_3 rep. 2 & $<5$ & $<5$ & 5.00 & $<5$ & 16.79 & 4814.00 & 104.80 & $<5$ & 14.49 & $<5$ & $<5$ & $<5$ & NS & 1147.00 \\
\hline WS_>18_CB_3 rep. 3 & $<5$ & $<5$ & 5.00 & $<5$ & 17.25 & 4789.00 & 106.60 & $<5$ & 15.04 & $<5$ & $<5$ & $<5$ & NS & 1491.00 \\
\hline Average & $<5$ & $<5$ & 6.78 & $<5$ & 17.04 & 4761.33 & 105.57 & $<5$ & 15.02 & $<5$ & $<5$ & $<5$ & & 1491.67 \\
\hline St dev & $\star *$ & $\star *$ & 3.08 & $* *$ & 0.23 & 70.68 & 0.93 & $* *$ & 0.53 & $\star *$ & $* *$ & $\star *$ & & 345.00 \\
\hline$\%$ St Dev & $\star *$ & ** & 45.41 & $* *$ & 1.36 & 1.48 & 0.88 & $* *$ & 3.50 & $\star *$ & ** & $* *$ & & 23.13 \\
\hline WS_<18_>50_CB_3rep. 1 & $<5 *$ & $<5^{*}$ & 14.41 & $<5 *$ & 23.47 & 5371.00 & 129.60 & $<5 *$ & 18.18 & $<5 *$ & 14.87 & $<5 *$ & NS & 2857.00 \\
\hline WS_<18_>50_CB_3rep. 2 & $<5$ & $<5$ & 42.88 & $<5$ & 18.86 & 3747.00 & 114.50 & $<5$ & 14.72 & $<5$ & 17.50 & $<5$ & NS & 2720.00 \\
\hline WS_<18_>50_CB_3rep. 3 & $<5$ & $<5$ & 12.56 & $<5$ & 18.90 & 4138.00 & 114.60 & $<5$ & 13.96 & $<5$ & 20.64 & $<5$ & NS & 1623.00 \\
\hline Average & $<5$ & $<5$ & 23.28 & $<5$ & 20.41 & 4418.67 & 119.57 & $<5$ & 15.62 & $<5$ & 17.67 & $<5$ & & 2400.00 \\
\hline St dev & ** & ** & 17.00 & $* *$ & 2.65 & 847.60 & 8.69 & $* *$ & 2.25 & $* *$ & 2.89 & $* *$ & & 676.38 \\
\hline$\%$ St Dev & $* *$ & $* *$ & 73.00 & $* *$ & 12.98 & 19.18 & 7.27 & $* *$ & 14.40 & $* *$ & 16.35 & $* *$ & & 28.18 \\
\hline WS_>50_CB_3 rep. 1 & $<5 *$ & $<5 *$ & $<5^{*}$ & $<5 *$ & 14.42 & 3805.00 & 106.10 & $<5 *$ & 12.34 & $<5 *$ & 15.79 & $<5 *$ & NS & 865.80 \\
\hline WS_>50_CB_3 rep. 2 & $<5$ & $<5$ & $<5$ & $<5$ & 15.87 & 3980.00 & 111.00 & $<5$ & 13.29 & $<5$ & 19.09 & $<5$ & NS & 892.80 \\
\hline WS_>50_CB_3 rep. 3 & $<5$ & $<5$ & $<5$ & $<5$ & 14.61 & 3792.00 & 108.70 & $<5$ & 12.54 & $<5$ & 14.10 & $<5$ & NS & 901.10 \\
\hline Average & $<5$ & $<5$ & $<5$ & $<5$ & 14.97 & 3859.00 & 108.60 & $<5$ & 12.72 & $<5$ & 16.33 & $<5$ & & 886.57 \\
\hline St dev & $* *$ & $\star *$ & $* *$ & $* *$ & 0.79 & 104.99 & 2.45 & $\star *$ & 0.50 & $\star *$ & 2.54 & $\star *$ & & 18.46 \\
\hline \% St Dev & $\star *$ & ** & ** & $* *$ & 5.27 & 2.72 & 2.26 & $* *$ & 3.94 & $* *$ & 15.54 & $* *$ & & 2.08 \\
\hline WS_<50_CB_3 rep. 1 & $<5 *$ & 5.00 & 24.50 & $<5 *$ & 32.10 & 7612.00 & 227.40 & $<5^{*}$ & 24.88 & $<5^{*}$ & $<5 *$ & $<5^{*}$ & 2150.00 & NS \\
\hline
\end{tabular}




\begin{tabular}{|c|c|c|c|c|c|c|c|c|c|c|c|c|c|c|}
\hline \multirow[t]{2}{*}{ Separation Procedure } & \multicolumn{14}{|c|}{ Metals (mg/kg) } \\
\hline & $\mathrm{Pb}$ & $\mathrm{Cr}$ & $\mathrm{Cu}$ & $\mathrm{Ni}$ & $\mathrm{Zn}$ & $\mathrm{Fe}$ & $\mathrm{Mn}$ & Mo & $\mathrm{V}$ & $\mathrm{Sb}$ & W & As & $\mathrm{Ca}$ & $\mathrm{U}$ \\
\hline WS_<50_CB_3 rep. 3 & $<5$ & 11.04 & 26.34 & $<5$ & 38.30 & 9137.00 & 249.50 & $<5$ & 28.73 & $<5$ & $<5$ & $<5$ & 2142.00 & NS \\
\hline St dev & ** & 3.49 & 1.12 & ** & 3.51 & 873.05 & 12.76 & ** & 2.45 & ** & ** & ** & 24.01 & \\
\hline \% St Dev & ** & 49.72 & 4.46 & $* *$ & 10.24 & 10.74 & 5.43 & $* *$ & 9.46 & ** & $* *$ & $* *$ & 1.11 & \\
\hline \multicolumn{15}{|c|}{$\begin{array}{l}\text { NDT= not determined. Sample consisted of large rocks. } \\
\text { NS - not sampled/no sample } \\
\text { *the laboratory reporting is used in place of non-detect values }\end{array}$} \\
\hline
\end{tabular}


Table C9. DU Garden 1 Wet Sieve Separations

\begin{tabular}{|c|c|c|c|c|c|c|c|c|c|c|c|c|c|c|}
\hline \multirow[t]{2}{*}{ Separation Procedure } & \multicolumn{14}{|c|}{ Metals (mg/kg) } \\
\hline & $\mathrm{Pb}$ & $\mathrm{Cr}$ & $\mathrm{Cu}$ & $\mathrm{Ni}$ & $\mathrm{Zn}$ & $\mathrm{Fe}$ & $\mathrm{Mn}$ & Mo & V & $\mathrm{Sb}$ & W & As & $\mathrm{Ca}$ & $U$ \\
\hline WS_>4_DG_1 rep. 1 & NDT & NDT & NDT & NDT & NDT & NDT & NDT & NDT & NDT & NDT & NDT & NDT & NS & $* * *$ \\
\hline WS_>4_DG_1 rep. 2 & NDT & NDT & NDT & NDT & NDT & NDT & NDT & NDT & NDT & NDT & NDT & NDT & NS & \\
\hline WS_>4_DG_1 rep. 3 & NDT & NDT & NDT & NDT & NDT & NDT & NDT & NDT & NDT & NDT & NDT & NDT & NS & \\
\hline \multicolumn{15}{|l|}{ Average } \\
\hline \multicolumn{15}{|l|}{ St dev } \\
\hline \multicolumn{15}{|l|}{$\%$ St Dev } \\
\hline WS_>10_DG_1 rep. 1 & $<5 *$ & $<5 *$ & $<5 *$ & $<5 *$ & 16.91 & 5316.00 & 223.60 & $<5 *$ & 14.09 & $<5 *$ & $<5 *$ & $<5 *$ & NS & $<5 *$ \\
\hline WS_>10_DG_1 rep. 2 & $<5$ & $<5$ & $<5$ & $<5$ & 17.54 & 5528.00 & 223.80 & $<5$ & 14.41 & $<5$ & $<5$ & $<5$ & NS & $<5$ \\
\hline WS_>10_DG_1 rep. 3 & $<5$ & $<5$ & $<5$ & $<5$ & 20.07 & 5444.00 & 223.70 & $<5$ & 14.23 & $<5$ & $<5$ & $<5$ & NS & $<5$ \\
\hline Average & $<5$ & $<5$ & $<5$ & $<5$ & 18.17 & 5429.33 & 223.70 & $<5$ & 14.24 & $<5$ & $<5$ & $<5$ & & $<5$ \\
\hline St dev & $* *$ & $* *$ & $* *$ & $* *$ & 1.67 & 106.76 & 0.10 & $* *$ & 0.16 & $* *$ & $* *$ & $* *$ & & $* *$ \\
\hline$\%$ St Dev & $* *$ & $* *$ & $* *$ & $* *$ & 9.20 & 1.97 & 0.04 & $* *$ & 1.13 & $* *$ & $* *$ & $* *$ & & $* *$ \\
\hline WS_>50_DG_1 rep. 1 & $<5 *$ & $<5 *$ & 5.00 & 11.90 & 23.70 & 6723.00 & 221.50 & $<5 *$ & 15.43 & $<5 *$ & $<5 *$ & $<5 *$ & NS & $<5 *$ \\
\hline WS_>50_DG_1 rep. 2 & $<5$ & $<5$ & 10.23 & 12.14 & 24.16 & 7133.00 & 221.90 & $<5$ & 16.89 & $<5$ & $<5$ & $<5$ & NS & $<5$ \\
\hline WS_>50_DG_1 rep. 3 & $<5$ & $<5$ & 5.00 & 11.62 & 22.58 & 6704.00 & 218.70 & $<5$ & 15.12 & $<5$ & $<5$ & $<5$ & NS & $<5$ \\
\hline Average & $<5$ & $<5$ & 6.74 & 11.89 & 23.48 & 6853.33 & 220.70 & $<5$ & 15.81 & $<5$ & $<5$ & $<5$ & & $<5$ \\
\hline St dev & $* *$ & $* *$ & 3.02 & 0.26 & 0.81 & 242.38 & 1.74 & $* *$ & 0.95 & $* *$ & $* *$ & $* *$ & & $* *$ \\
\hline$\%$ St Dev & $* *$ & $* *$ & 44.78 & 2.19 & 3.46 & 3.54 & 0.79 & $* *$ & 5.98 & $* *$ & $* *$ & $* *$ & & $* *$ \\
\hline WS_<50_DG_1 rep. 1 & $<5^{*}$ & $<5 *$ & 10.92 & $<5 *$ & 24.98 & 6312.00 & 192.00 & $<5 *$ & 11.95 & $<5 *$ & $<5 *$ & $<5 *$ & NS & $<5 *$ \\
\hline WS_<50_DG_1 rep. 2 & $<5$ & $<5$ & 11.11 & $<5$ & 24.91 & 6494.00 & 193.20 & $<5$ & 13.90 & $<5$ & $<5$ & $<5$ & NS & $<5$ \\
\hline WS_<50_DG_1 rep. 3 & $<5$ & $<5$ & 10.91 & $<5$ & 23.89 & 6145.00 & 189.00 & $<5$ & 11.98 & $<5$ & $<5$ & $<5$ & NS & $<5$ \\
\hline Average & $<5$ & $<5$ & 10.98 & $<5$ & 24.59 & 6317.00 & 191.40 & $<5$ & 12.61 & $<5$ & $<5$ & $<5$ & & $<5$ \\
\hline St dev & $* *$ & $* *$ & 0.11 & $* *$ & 0.61 & 174.55 & 2.16 & $* *$ & 1.12 & $* *$ & $* *$ & $* *$ & & $* *$ \\
\hline$\%$ St Dev & $* *$ & $* *$ & 1.03 & $* *$ & 2.48 & 2.76 & 1.13 & $* *$ & 8.86 & $* *$ & $* *$ & $* *$ & & $* *$ \\
\hline $\begin{array}{l}\text { NDT = not determined. Sampl } \\
\text { NS - not sampled/no sample } \\
\text { *the laboratory reporting is us } \\
\text { **-no standard deviation for } \\
* * * \text { - concentration determin }\end{array}$ & $\begin{array}{l}\text { isted o } \\
\text { place o } \\
\text { vimetri } \\
\text { vimet }\end{array}$ & $\begin{array}{l}\text { arge ro } \\
\text { non-de } \\
<5 \mathrm{mg} \\
\text { lly as c }\end{array}$ & $\begin{array}{l}\text { KS. } \\
\text { ct values } \\
\text { kg IDL Wc } \\
\text { scribed i }\end{array}$ & $\begin{array}{l}\text { sed in ca } \\
\text { e text. }\end{array}$ & lations. & & & & & & & & & \\
\hline
\end{tabular}


Table C10. DU Garden 2 Wet Sieve Separations

\begin{tabular}{|c|c|c|c|c|c|c|c|c|c|c|c|c|c|c|}
\hline Separation Procedure & $\mathrm{Pb}$ & $\mathrm{Cr}$ & $\mathrm{Cu}$ & $\mathrm{Ni}$ & $\mathrm{Zn}$ & $\mathrm{Fe}$ & $\mathrm{Mn}$ & Mo & $\mathrm{V}$ & $\mathrm{Sb}$ & W & As & $\mathrm{Ca}$ & U \\
\hline WS_>4_DG_1 rep. 2 & NDT & NDT & NDT & NDT & NDT & NDT & NDT & NDT & NDT & NDT & NDT & NDT & NS & \\
\hline WS_>4_DG_1 rep. 3 & NDT & NDT & NDT & NDT & NDT & NDT & NDT & NDT & NDT & NDT & NDT & NDT & NS & \\
\hline \multicolumn{15}{|l|}{ St dev } \\
\hline \multicolumn{15}{|l|}{ \% St Dev } \\
\hline WS_>10_DG_2 rep. 1 & 25.14 & 11.33 & $<5 *$ & 13.28 & 22.35 & 6858.00 & 270.40 & $<5^{*}$ & 16.62 & $<5^{*}$ & $<5^{*}$ & $<5 *$ & NS & $<5 *$ \\
\hline WS_>10_DG_2 rep. 2 & 5.00 & 12.31 & $<5$ & 14.18 & 24.07 & 7426.00 & 278.80 & $<5$ & 17.96 & $<5$ & $<5$ & $<5$ & NS & $<5$ \\
\hline WS_>10_DG_2 rep. 3 & 5.00 & 12.47 & $<5$ & 14.36 & 24.63 & 7602.00 & 282.80 & $<5$ & 18.11 & $<5$ & $<5$ & $<5$ & NS & $<5$ \\
\hline WS_>50_DG_2 rep. 2 & $<5$ & 5.00 & 11.00 & 12.48 & 24.13 & 6790.00 & 244.20 & $<5$ & 16.25 & $<5$ & $<5$ & $<5$ & $<5$ & $<5$ \\
\hline WS_>50_DG_2 rep. 3 & $<5$ & 5.00 & 10.71 & 12.31 & 22.46 & 6555.00 & 243.70 & $<5$ & 15.89 & $<5$ & $<5$ & $<5$ & $<5$ & $<5$ \\
\hline Average & $<5$ & 6.77 & 10.89 & 12.54 & 23.59 & 6765.67 & 245.10 & $<5$ & 16.17 & $<5$ & $<5$ & $<5$ & $<5$ & $<5$ \\
\hline St dev & $\star *$ & 3.07 & 0.16 & 0.27 & 0.98 & 199.62 & 2.01 & $* *$ & 0.25 & $* *$ & $* *$ & $* *$ & $* *$ & $\star *$ \\
\hline \% St Dev & $* *$ & 45.28 & 1.44 & 2.16 & 4.14 & 2.95 & 0.82 & $* *$ & 1.52 & $* *$ & $* *$ & $* *$ & $* *$ & $* *$ \\
\hline WS_<50_DG_2 rep. 1 & $<5 *$ & $<5$ & 12.48 & 5.00 & 25.28 & 6131.00 & 224.10 & $<5^{*}$ & 13.06 & $<5 *$ & $<5^{*}$ & $<5^{*}$ & NS & $<5 *$ \\
\hline WS_<50_DG_2 rep. 2 & $<5$ & $<5$ & 13.14 & 10.10 & 27.73 & 7110.00 & 232.00 & $<5$ & 15.08 & $<5$ & $<5$ & $<5$ & NS & $<5$ \\
\hline WS_<50_DG_2 rep. 3 & $<5$ & $<5$ & 12.69 & 5.00 & 25.24 & 6270.00 & 228.40 & $<5$ & 13.45 & $<5$ & $<5$ & $<5$ & NS & $<5$ \\
\hline Average & $<5$ & $<5$ & 12.77 & 6.70 & 26.08 & 6503.67 & 228.17 & $<5$ & 13.86 & $<5$ & $<5$ & $<5$ & & $<5$ \\
\hline
\end{tabular}


Table C11. DU Garden 3 Wet Sieve Separations

\begin{tabular}{|c|c|c|c|c|c|c|c|c|c|c|c|c|c|c|}
\hline \multirow[t]{2}{*}{ Separation Procedure } & \multicolumn{14}{|c|}{ Metals (mg/kg) } \\
\hline & $\mathrm{Pb}$ & $\mathrm{Cr}$ & $\mathrm{Cu}$ & $\mathrm{Ni}$ & $\mathrm{Zn}$ & $\mathrm{Fe}$ & $\mathrm{Mn}$ & Mo & V & $\mathrm{Sb}$ & W & As & $\mathrm{Ca}$ & U \\
\hline WS_>4_DG_3 rep. 1 & NDT & NDT & NDT & NDT & NDT & NDT & NDT & NDT & NDT & NDT & NDT & NDT & NS & $* * *$ \\
\hline WS_>4_DG_3 rep. 2 & NDT & NDT & NDT & NDT & NDT & NDT & NDT & NDT & NDT & NDT & NDT & NDT & NS & \\
\hline WS_>4_DG_3 rep. 3 & NDT & NDT & NDT & NDT & NDT & NDT & NDT & NDT & NDT & NDT & NDT & NDT & NS & \\
\hline \multicolumn{15}{|l|}{ Average } \\
\hline \multicolumn{15}{|l|}{ St dev } \\
\hline \multicolumn{15}{|l|}{ \% St Dev } \\
\hline WS_>10_DG_3 rep.1 & $<5 *$ & 11.92 & $<5 *$ & 13.70 & 21.50 & 6580.00 & 277.30 & $<5 *$ & 13.81 & $<5 *$ & 16.49 & $<5^{*}$ & NS & $<5 *$ \\
\hline WS_>10_DG_3 rep. 2 & $<5$ & 14.99 & $<5$ & 17.57 & 27.83 & 8587.00 & 305.70 & $<5$ & 17.72 & $<5$ & 14.73 & $<5$ & NS & $<5$ \\
\hline WS_>10_DG_3 rep. 3 & $<5$ & 12.71 & $<5$ & 14.61 & 24.27 & 7011.00 & 281.50 & $<5$ & 15.23 & $<5$ & 13.59 & $<5$ & NS & $<5$ \\
\hline Average & $<5$ & 13.21 & $<5$ & 15.29 & 24.53 & 7392.67 & 288.17 & $<5$ & 15.59 & $<5$ & 14.94 & $<5$ & & $<5$ \\
\hline St dev & $* *$ & 1.59 & $* *$ & 2.02 & 3.17 & 1056.53 & 15.33 & $* *$ & 1.98 & $* *$ & 1.46 & $* *$ & & $* *$ \\
\hline$\%$ St Dev & $* *$ & 12.07 & $* *$ & 13.23 & 12.93 & 14.29 & 5.32 & $* *$ & 12.70 & $* *$ & 9.78 & $* *$ & & $* *$ \\
\hline WS_>50_DG_3 rep. 1 & $<5 *$ & $<5 *$ & 5.00 & 10.16 & 19.67 & 5185.00 & 224.70 & $<5 *$ & $<5$ & $<5 *$ & $<5$ & $<5 *$ & NS & $<5 *$ \\
\hline WS_>50_DG_3 rep. 2 & $<5$ & $<5$ & 10.04 & 12.46 & 23.45 & 6300.00 & 237.10 & $<5$ & 12.55 & $<5$ & 13.16 & $<5$ & NS & $<5$ \\
\hline WS_>50_DG_3 rep. 3 & 10.61 & $<5$ & 53.72 & 13.57 & 37.08 & 5272.00 & 227.20 & $<5$ & 10.24 & $<5$ & 10.51 & $<5$ & NS & $<5$ \\
\hline Average & 6.87 & $<5$ & 22.92 & 12.06 & 26.73 & 5585.67 & 229.67 & $<5$ & 11.40 & $<5$ & 11.84 & $<5$ & & $<5$ \\
\hline St dev & 3.24 & $* *$ & 26.79 & 1.74 & 9.16 & 620.16 & 6.56 & $* *$ & 1.63 & $* *$ & 1.87 & $* *$ & & $* *$ \\
\hline$\%$ St Dev & 47.15 & $* *$ & 116.90 & 14.42 & 34.26 & 11.10 & 2.86 & $* *$ & 14.33 & $* *$ & 15.83 & $* *$ & & $* *$ \\
\hline WS_<50_DG_3 rep. 1 & $<5 *$ & $<5 *$ & 11.86 & $<5 *$ & 24.46 & 6102.00 & 206.10 & $<5 *$ & $<5^{*}$ & $<5 *$ & 14.63 & $<5 *$ & NS & $<5 *$ \\
\hline WS_<50_DG_3 rep. 2 & $<5$ & $<5$ & 12.96 & $<5$ & 25.31 & 6071.00 & 208.70 & $<5$ & $<5$ & $<5$ & 5.00 & $<5$ & NS & $<5$ \\
\hline WS_<50_DG_3 rep. 3 & 10.46 & $<5$ & 20.53 & 10.18 & 28.41 & 6128.00 & 214.60 & $<5$ & $<5$ & $<5$ & 5.00 & $<5$ & NS & $<5$ \\
\hline Average & 6.82 & $<5$ & 15.12 & 6.73 & 26.06 & 6100.33 & 209.80 & $<5$ & $<5$ & $<5$ & 8.21 & $<5$ & & $<5$ \\
\hline St dev & 3.15 & $* *$ & 4.72 & 2.99 & 2.08 & 28.54 & 4.36 & $* *$ & $* *$ & $* *$ & 5.56 & $* *$ & & $* *$ \\
\hline$\%$ St Dev & 46.22 & $* *$ & 31.23 & 44.46 & 7.98 & 0.47 & 2.08 & $* *$ & $* *$ & $* *$ & 67.72 & $* *$ & & $* *$ \\
\hline \multicolumn{15}{|c|}{$\begin{array}{l}\text { NDT }=\text { not determined. Sample consisted of large rocks. } \\
\text { NS - not sampled/no sample } \\
* \text { the laboratory reporting is used in place of non-detect values } \\
\star * \text {-no standard deviation for samples where }<5 \mathrm{mg} / \mathrm{kg} \text { IDL was used in calculations. } \\
\star * * \text { - concentration determined gravimetrically as described in the text. }\end{array}$} \\
\hline
\end{tabular}


Table C12. DU Garden 4 Wet Sieve Separations

\begin{tabular}{|c|c|c|c|c|c|c|c|c|c|c|c|c|c|c|}
\hline \multirow[t]{2}{*}{ Separation Procedure } & \multicolumn{14}{|c|}{ Metals (mg/kg) } \\
\hline & $\mathrm{Pb}$ & $\mathrm{Cr}$ & $\mathrm{Cu}$ & $\mathrm{Ni}$ & $\mathrm{Zn}$ & $\mathrm{Fe}$ & $\mathrm{Mn}$ & Mo & V & $\mathrm{Sb}$ & W & As & $\mathrm{Ca}$ & U \\
\hline WS_>4_DG_4 rep. 1 & NDT & NDT & NDT & NDT & NDT & NDT & NDT & NDT & NDT & NDT & NDT & NDT & NS & $* * *$ \\
\hline WS_>4_DG_4 rep. 2 & NDT & NDT & NDT & NDT & NDT & NDT & NDT & NDT & NDT & NDT & NDT & NDT & NS & \\
\hline WS_>4_DG_4 rep. 3 & NDT & NDT & NDT & NDT & NDT & NDT & NDT & NDT & NDT & NDT & NDT & NDT & NS & \\
\hline \multicolumn{15}{|l|}{ Average } \\
\hline \multicolumn{15}{|l|}{ St dev } \\
\hline \multicolumn{15}{|l|}{ \% St Dev } \\
\hline WS_>10_DG_4 rep. 1 & $<5 *$ & 10.43 & $<5^{*}$ & 11.76 & 20.61 & 6838.00 & 243.40 & $<5 *$ & 18.72 & $<5 *$ & 32.12 & $<5 *$ & NS & 375.40 \\
\hline WS_>10_DG_4 rep. 2 & $<5$ & 12.58 & $<5$ & 13.89 & 23.89 & 8038.00 & 262.00 & $<5$ & 21.21 & $<5$ & 27.17 & $<5$ & NS & 290.20 \\
\hline WS_>10_DG_4 rep. 3 & $<5$ & 11.02 & $<5$ & 14.00 & 21.11 & 7190.00 & 251.60 & $<5$ & 19.29 & $<5$ & 32.91 & $<5$ & NS & 314.90 \\
\hline Average & $<5$ & 11.34 & $<5$ & 13.22 & 21.87 & 7355.33 & 252.33 & $<5$ & 19.74 & $<5$ & 30.73 & $<5$ & & 326.83 \\
\hline St dev & $* *$ & 1.11 & $* *$ & 1.26 & 1.77 & 616.85 & 9.32 & ** & 1.30 & $* *$ & 3.11 & $* *$ & & 43.84 \\
\hline \% St Dev & $* *$ & 9.79 & $* *$ & 9.55 & 8.08 & 8.39 & 3.69 & $* *$ & 6.61 & $* *$ & 10.12 & $* *$ & & 13.41 \\
\hline WS_>50_DG_4 rep. 1 & $<5 *$ & 10.83 & 11.33 & 11.51 & 20.61 & 6512.00 & 226.00 & $<5 *$ & 19.64 & $<5 *$ & $<5 *$ & $<5 *$ & NS & 1859.00 \\
\hline WS_>50_DG_4 rep. 2 & $<5$ & $<5$ & 11.09 & 10.88 & 18.73 & 5941.00 & 207.10 & $<5$ & 18.69 & $<5$ & $<5$ & $<5$ & NS & 1889.00 \\
\hline WS_>50_DG_4 rep. 3 & $<5$ & 10.95 & 11.55 & 11.96 & 21.04 & 6720.00 & 221.60 & $<5$ & 20.50 & $<5$ & $<5$ & $<5$ & NS & 1850.00 \\
\hline Average & $<5$ & 10.89 & 11.32 & 11.45 & 20.13 & 6391.00 & 218.23 & $<5$ & 19.61 & $<5$ & $<5$ & $<5$ & & 1866.00 \\
\hline St dev & ** & 0.08 & 0.23 & 0.54 & 1.23 & 403.35 & 9.89 & ** & 0.91 & $* *$ & $* *$ & $\star *$ & & 20.42 \\
\hline$\%$ St Dev & $* *$ & 0.78 & 2.03 & 4.74 & 6.10 & 6.31 & 4.53 & $* *$ & 4.62 & $* *$ & $* *$ & $* *$ & & 1.09 \\
\hline WS_<50_DG_4 rep. 1 & $<5 *$ & $<5 *$ & $<5 *$ & $<5 *$ & 15.55 & 4103.00 & 142.00 & $<5 *$ & 12.84 & $<5 *$ & $<5 *$ & $<5 *$ & NS & 1481.00 \\
\hline WS_<50_DG_4 rep. 2 & $<5$ & $<5$ & 10.61 & $<5$ & 20.01 & 5608.00 & 171.80 & $<5$ & 14.80 & $<5$ & $<5$ & $<5$ & NS & 1399.00 \\
\hline WS_<50_DG_4 rep. 3 & $<5$ & $<5$ & 10.18 & $<5$ & 20.51 & 5091.00 & 155.00 & $<5$ & 13.87 & $<5$ & $<5$ & $<5$ & NS & 1417.00 \\
\hline Average & $<5$ & $<5$ & 10.40 & $<5$ & 18.69 & 4934.00 & 156.27 & $<5$ & 13.84 & $<5$ & $<5$ & $<5$ & & 1432.33 \\
\hline St dev & $* *$ & $* *$ & 0.30 & $* *$ & 2.73 & 764.68 & 14.94 & ** & 0.98 & $* *$ & $* *$ & $* *$ & & 43.10 \\
\hline$\%$ St Dev & $\star *$ & $\star *$ & 2.93 & $* *$ & 14.61 & 15.50 & 9.56 & $* *$ & 7.09 & $\star *$ & $* *$ & $* *$ & & 3.01 \\
\hline \multicolumn{15}{|c|}{$\begin{array}{l}\text { NDT = not determined. Sample consisted of large rocks. } \\
\text { NS - not sampled/no sample } \\
\text { *the laboratory reporting is used in place of non-detect values } \\
* * \text {-no standard deviation for samples where }<5 \mathrm{mg} / \mathrm{kg} \text { IDL was used in calculations. } \\
* * * \text { - concentration determined gravimetrically as described in the text. }\end{array}$} \\
\hline
\end{tabular}


Table C13. DU Garden 5 Wet Sieve Separations

\begin{tabular}{|c|c|c|c|c|c|c|c|c|c|c|c|c|c|c|}
\hline \multirow[t]{2}{*}{ Separation Procedure } & \multicolumn{14}{|c|}{ Metals (mg/kg) } \\
\hline & $\mathrm{Pb}$ & $\mathrm{Cr}$ & $\mathrm{Cu}$ & $\mathrm{Ni}$ & $\mathrm{Zn}$ & $\mathrm{Fe}$ & $\mathrm{Mn}$ & Mo & V & $\mathrm{Sb}$ & W & As & $\mathrm{Ca}$ & $U$ \\
\hline WS_>4_DG_5 rep. 1 & NDT & NDT & NDT & NDT & NDT & NDT & NDT & NDT & NDT & NDT & NDT & NDT & NS & $* * *$ \\
\hline WS_>4_DG_5 rep. 2 & NDT & NDT & NDT & NDT & NDT & NDT & NDT & NDT & NDT & NDT & NDT & NDT & NS & \\
\hline WS_>4_DG_5 rep. 3 & NDT & NDT & NDT & NDT & NDT & NDT & NDT & NDT & NDT & NDT & NDT & NDT & NS & \\
\hline \multicolumn{15}{|l|}{ Average } \\
\hline \multicolumn{15}{|l|}{ St dev } \\
\hline \multicolumn{15}{|l|}{$\%$ St Dev } \\
\hline WS_>10_DG_5 rep. 1 & $<5 *$ & 15.80 & 10.67 & 20.14 & 31.81 & 9792.00 & 324.80 & $<5 *$ & 24.99 & $<5^{*}$ & 10.99 & $<5^{*}$ & NS & 407.80 \\
\hline WS_>10_DG_5 rep. 2 & $<5$ & 16.12 & 10.85 & 18.88 & 31.02 & 10400.00 & 333.20 & $<5$ & 26.46 & $<5$ & 11.26 & $<5$ & NS & 373.30 \\
\hline WS_>10_DG_5 rep. 3 & 11.27 & 15.94 & 10.92 & 18.16 & 32.38 & 10060.00 & 328.10 & $<5$ & 25.49 & $<5$ & $<5$ & $<5$ & NS & 374.40 \\
\hline Average & 7.09 & 15.95 & 10.81 & 19.06 & 31.74 & 10084.00 & 328.70 & $<5$ & 25.65 & $<5$ & 11.13 & $<5$ & & 385.17 \\
\hline St dev & 3.62 & 0.16 & 0.13 & 1.00 & 0.68 & 304.71 & 4.23 & $* *$ & 0.75 & $* *$ & 0.19 & $* *$ & & 19.61 \\
\hline$\%$ St Dev & 51.06 & 1.01 & 1.19 & 5.26 & 2.15 & 3.02 & 1.29 & $* *$ & 2.91 & $* *$ & 1.72 & $* *$ & & 5.09 \\
\hline WS_>50_DG_5 rep. 1 & 54.25 & 60.61 & 51.85 & 21.31 & 30.96 & 8360.00 & 242.60 & $<5 *$ & 91.47 & $<5^{*}$ & $<5 *$ & $<5 *$ & NS & 34380.00 \\
\hline WS_>50_DG_5 rep. 2 & 54.76 & 63.66 & 53.47 & 21.80 & 33.57 & 8813.00 & 249.50 & $<5$ & 93.82 & $<5$ & $<5$ & $<5$ & NS & 35100.00 \\
\hline WS_>50_DG_5 rep. 3 & 56.20 & 61.31 & 52.60 & 21.54 & 30.26 & 8474.00 & 242.00 & $<5$ & 93.33 & $<5$ & $<5$ & $<5$ & NS & 35020.00 \\
\hline Average & 55.07 & 61.86 & 52.64 & 21.55 & 31.60 & 8549.00 & 244.70 & $<5$ & 92.87 & $<5$ & $<5$ & $<5$ & & 34833.33 \\
\hline St dev & 1.01 & 1.60 & 0.81 & 0.25 & 1.74 & 235.63 & 4.17 & $* *$ & 1.24 & $* *$ & $\star *$ & $\star *$ & & 394.63 \\
\hline$\%$ St Dev & 1.84 & 2.58 & 1.54 & 1.14 & 5.52 & 2.76 & 1.70 & $* *$ & 1.33 & $* *$ & $\star *$ & $* *$ & & 1.13 \\
\hline WS_<50_DG_5 rep. 1 & 74.90 & 83.33 & 71.25 & 18.98 & 28.55 & 7316.00 & 203.40 & $<5 *$ & 125.00 & $<5 *$ & $<5 *$ & $<5 *$ & NS & 50510.00 \\
\hline WS_<50_DG_5 rep. 2 & 74.72 & 79.60 & 70.59 & 17.60 & 26.59 & 5177.00 & 172.80 & $<5$ & 119.80 & $<5$ & $<5$ & $<5$ & NS & 52010.00 \\
\hline WS_<50_DG_5 rep. 3 & 71.18 & 80.90 & 69.15 & 17.51 & 19.71 & 4795.00 & 174.00 & $<5$ & 118.00 & $<5$ & $<5$ & $<5$ & NS & 51610.00 \\
\hline Average & 73.60 & 81.28 & 70.33 & 18.03 & 24.95 & 5762.67 & 183.40 & $<5$ & 120.93 & $<5$ & $<5$ & $<5$ & & 51376.67 \\
\hline St dev & 2.10 & 1.89 & 1.07 & 0.82 & 4.64 & 1358.72 & 17.33 & $* *$ & 3.64 & $\star *$ & $\star *$ & $* *$ & & 776.75 \\
\hline$\%$ St Dev & 2.85 & 2.33 & 1.53 & 4.57 & 18.61 & 23.58 & 9.45 & $* *$ & 3.01 & $* *$ & $* *$ & $* *$ & & 1.51 \\
\hline \multicolumn{15}{|c|}{$\begin{array}{l}\text { NDT }=\text { not determined. Sample consisted of large rocks. } \\
\text { NS - not sampled/no sample } \\
\text { *the laboratory reporting is used in place of non-detect values } \\
\star * * \text {-no standard deviation for samples where }<5 \mathrm{mg} / \mathrm{kg} \text { IDL was used in calculations. } \\
* * * \text { - concentration determined gravimetrically as described in the text. }\end{array}$} \\
\hline
\end{tabular}


Table C14. Range 20-1 Wet Sieve

\begin{tabular}{|c|c|c|c|c|c|c|c|c|c|c|c|c|c|c|}
\hline Separation Procedure & \multicolumn{14}{|c|}{ Metals (mg/kg) } \\
\hline & $\mathrm{Pb}$ & $\mathrm{Cr}$ & $\mathrm{Cu}$ & $\mathrm{Ni}$ & $\mathrm{Zn}$ & $\mathrm{Fe}$ & $\mathrm{Mn}$ & Mo & $\mathrm{v}$ & $\mathrm{Sb}$ & W & As & $\mathrm{Ca}$ & U \\
\hline WS_>4_20_1 rep. 1 & NDT & NDT & NDT & NDT & NDT & NDT & NDT & NDT & NDT & NDT & NDT & NDT & NS & $* * *$ \\
\hline WS_>4_20_1 rep. 3 & NDT & NDT & NDT & NDT & NDT & NDT & NDT & NDT & NDT & NDT & NDT & NDT & NS & \\
\hline \multicolumn{15}{|l|}{ Average } \\
\hline \multicolumn{15}{|l|}{ St dev } \\
\hline WS_>10_20_1 rep. 2 & $<5$ & 15.88 & 15.52 & 16.46 & 32.20 & 10800.00 & 280.40 & $<5$ & 30.98 & $<5$ & $<5$ & $<5$ & NS & $<5$ \\
\hline WS_>10_20_1 rep. 3 & $<5$ & 14.31 & 15.12 & 15.85 & 30.89 & 10030.00 & 274.00 & $<5$ & 29.37 & $<5$ & 11.38 & $<5$ & NS & $<5$ \\
\hline Average & $<5$ & 15.01 & 15.13 & 15.96 & 31.12 & 10191.33 & 274.63 & $<5$ & 29.51 & $<5$ & 12.06 & $<5$ & & $<5$ \\
\hline St dev & $* *$ & 0.80 & 0.39 & 0.46 & 0.99 & 546.17 & 5.48 & $* *$ & 1.41 & $* *$ & 0.96 & $* *$ & & $* *$ \\
\hline$\%$ St Dev & ** & 5.31 & 2.55 & 2.85 & 3.17 & 5.36 & 1.99 & $* *$ & 4.76 & $* *$ & 7.97 & ** & & ** \\
\hline WS_>50_20_1 rep. 1 & 24.23 & 28.38 & 59.55 & 14.39 & 25.29 & 7838.00 & 217.00 & $<5 *$ & 49.23 & $<5 *$ & $<5 *$ & $<5^{\star}$ & 19970.00 & 15180.00 \\
\hline$\%$ St Dev & 1.21 & 1.42 & 1.47 & 2.62 & 3.84 & 4.52 & 0.46 & $* *$ & 2.11 & $* *$ & ** & ** & 2.63 & 2.97 \\
\hline WS_<50_20_1 & 20.41 & 25.06 & 69.92 & 19.50 & 30.38 & 7954.00 & 209.90 & $<5^{*}$ & 46.07 & $<5^{*}$ & $<5 *$ & $<5^{*}$ & 41040.00 & 11570.00 \\
\hline 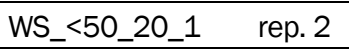 & 19.80 & 25.34 & 70.50 & 12.33 & 29.29 & 7478.00 & 204.50 & $<5$ & 45.58 & $<5$ & $<5$ & $<5$ & 41550.00 & 11820.00 \\
\hline WS_<50_20_1 rep. 3 & 19.30 & 23.73 & 69.42 & 12.31 & 29.11 & 7418.00 & 204.20 & $<5$ & 45.11 & $<5$ & $<5$ & $<5$ & 41900.00 & 11760.00 \\
\hline Average & 19.84 & 24.71 & 69.95 & 14.71 & 29.59 & 7616.67 & 206.20 & $<5$ & 45.59 & $<5$ & $<5$ & $<5$ & 41496.67 & 11716.67 \\
\hline St dev & 0.56 & 0.86 & 0.54 & 4.15 & 0.69 & 293.68 & 3.21 & $* *$ & 0.48 & $* *$ & ** & ** & 432.47 & 130.51 \\
\hline$\%$ St Dev & 2.80 & 3.48 & 0.77 & 28.17 & 2.32 & 3.86 & 1.56 & $* *$ & 1.05 & $* *$ & ** & ** & 1.04 & 1.11 \\
\hline \multicolumn{15}{|c|}{$\begin{array}{l}\text { NDT = not determined. Sample consisted of large rocks. } \\
\text { NS - not sampled/no sample } \\
* \text { the laboratory reporting is used in place of non-detect values } \\
* * \text {-no standard deviation for samples where }<5 \mathrm{mg} / \mathrm{kg} \text { IDL was used in calculations. } \\
* * * \text { - concentration determined gravimetrically as described in the text. }\end{array}$} \\
\hline
\end{tabular}


Table C15. Range 20 soil masses, DU mass and DU \% of total by size fraction as determined by wet sieve separation.

\begin{tabular}{|c|c|c|c|c|c|c|c|c|c|}
\hline \multirow[t]{2}{*}{ Size Fraction } & \multicolumn{3}{|c|}{ Soil Mass } & \multicolumn{3}{|c|}{ Mg of DU } & \multicolumn{3}{|c|}{ \% Total U per Size Fraction } \\
\hline & $20-1$ & $20-2$ & $20-3$ & $20-1$ & $20-2$ & $20-3$ & $20-1$ & $20-2$ & $20-3$ \\
\hline$>4.76 \mathrm{~mm}$ & 0.17 & 0.22 & 0.21 & 0.01 & 0.01 & 0.01 & $0.00 \%$ & $0.00 \%$ & $0.00 \%$ \\
\hline$<4.76 \mathrm{~mm}$ to $>2.00 \mathrm{~mm}$ & 0.15 & 0.16 & 0.17 & 0.01 & 328.43 & 471.30 & $0.00 \%$ & $2.84 \%$ & $3.85 \%$ \\
\hline$<2.00 \mathrm{~mm}$ to $>0.30 \mathrm{~mm}$ & 0.31 & 0.28 & 0.29 & 4661.40 & 4572.40 & 5785.77 & $58.26 \%$ & $39.60 \%$ & $47.28 \%$ \\
\hline$<0.30 \mathrm{~mm}$ & 0.29 & 0.32 & 0.32 & 3339.35 & 6645.19 & 5980.80 & $41.74 \%$ & $57.55 \%$ & $48.87 \%$ \\
\hline Total & 0.91 & 0.99 & 0.99 & 8000.67 & 11546.02 & 12237.88 & & & \\
\hline
\end{tabular}


Table C16. Range 20-2 Wet Sieve

\begin{tabular}{|c|c|c|c|c|c|c|c|c|c|c|c|c|c|c|}
\hline Separation Procedure & \multicolumn{14}{|c|}{ Metals (mg/kg) } \\
\hline & $\mathrm{Pb}$ & $\mathrm{Cr}$ & $\mathrm{Cu}$ & $\mathrm{Ni}$ & $\mathrm{Zn}$ & $\mathrm{Fe}$ & $\mathrm{Mn}$ & Mo & $\mathrm{V}$ & $\mathrm{Sb}$ & W & As & $\mathrm{Ca}$ & U \\
\hline WS_>4_20_2 rep. 1 & NDT & NDT & NDT & NDT & NDT & NDT & NDT & NDT & NDT & NDT & NDT & NDT & NS & $* * *$ \\
\hline WS_>4_20_2 rep. 2 & NDT & NDT & NDT & NDT & NDT & NDT & NDT & NDT & NDT & NDT & NDT & NDT & NS & \\
\hline WS_>4_20_2 rep. 3 & NDT & NDT & NDT & NDT & NDT & NDT & NDT & NDT & NDT & NDT & NDT & NDT & NS & \\
\hline \multicolumn{15}{|l|}{ Average } \\
\hline \multicolumn{15}{|l|}{ St dev } \\
\hline \multicolumn{15}{|l|}{$\%$ St Dev } \\
\hline WS_>10_20_2 rep.1 & $<5$ & 16.58 & 14.36 & 15.79 & 30.13 & 9387.00 & 285.30 & $<5 *$ & 31.76 & $<5 *$ & $<5 *$ & $<5 *$ & NS & 2010.00 \\
\hline WS_>10_20_2 rep. 2 & 12.36 & 16.95 & 14.45 & 16.13 & 29.45 & 9600.00 & 293.50 & $<5$ & 32.29 & $<5$ & $<5$ & $<5$ & NS & 2066.00 \\
\hline WS_>10_20_2 rep.3 & 10.86 & 16.89 & 15.13 & 16.47 & 31.56 & 9803.00 & 290.10 & $<5$ & 32.91 & $<5$ & $<5$ & $<5$ & NS & 2006.00 \\
\hline Average & 11.61 & 16.81 & 14.65 & 16.13 & 30.38 & 9596.67 & 289.63 & $<5$ & 32.32 & $<5$ & $<5$ & $<5$ & & 2027.33 \\
\hline St dev & 1.06 & 0.20 & 0.42 & 0.34 & 1.08 & 208.02 & 4.12 & $* *$ & 0.58 & $* *$ & $* *$ & $* *$ & & 33.55 \\
\hline \% St Dev & 9.14 & 1.18 & 2.87 & 2.11 & 3.55 & 2.17 & 1.42 & $* *$ & 1.78 & $* *$ & $* *$ & $* *$ & & 1.65 \\
\hline WS_>50_20_2 rep.1 & 29.72 & 23.77 & 47.91 & 15.99 & 29.39 & 8818.00 & 251.60 & $<5^{*}$ & 47.16 & $<5 *$ & $<5 *$ & $<5 *$ & NS & 16310.00 \\
\hline WS_>50_20_2 rep. 2 & 25.84 & 25.27 & 47.83 & 15.36 & 27.55 & 8822.00 & 242.20 & $<5$ & 48.08 & $<5$ & $<5$ & $<5$ & NS & 15840.00 \\
\hline WS_>50_20_2 rep. 3 & 27.55 & 24.60 & 49.86 & 15.90 & 29.00 & 9310.00 & 250.70 & $<5$ & 48.57 & $<5$ & $<5$ & $<5$ & NS & 16150.00 \\
\hline Average & 27.70 & 24.55 & 48.53 & 15.75 & 28.65 & 8983.33 & 248.17 & $<5$ & 47.94 & $<5$ & $<5$ & $<5$ & & 16100.00 \\
\hline St dev & 1.94 & 0.75 & 1.15 & 0.34 & 0.97 & 282.91 & 5.19 & $* *$ & 0.72 & $* *$ & $* *$ & $* *$ & & 238.96 \\
\hline$\%$ St Dev & 7.02 & 3.06 & 2.37 & 2.16 & 3.38 & 3.15 & 2.09 & $* *$ & 1.49 & $* *$ & $* *$ & $* *$ & & 1.48 \\
\hline WS_<50_20_2 rep. 1 & 32.97 & 28.08 & 62.70 & 13.80 & 26.96 & 8387.00 & 219.50 & $<5 *$ & 51.39 & $<5 *$ & $<5 *$ & $<5^{*}$ & NS & 20380.00 \\
\hline WS_<50_20_2 rep. 2 & 34.94 & 28.29 & 63.93 & 13.42 & 27.26 & 8126.00 & 217.90 & $<5$ & 51.40 & $<5$ & $<5$ & $<5$ & NS & 20510.00 \\
\hline WS_<50_20_2 rep. 3 & 33.00 & 27.15 & 62.67 & 13.36 & 26.70 & 7894.00 & 217.70 & $<5$ & 50.17 & $<5$ & $<5$ & $<5$ & NS & 20830.00 \\
\hline Average & 33.64 & 27.84 & 63.10 & 13.53 & 26.97 & 8135.67 & 218.37 & $<5$ & 50.99 & $<5$ & $<5$ & $<5$ & & 20573.33 \\
\hline St dev & 1.13 & 0.61 & 0.72 & 0.24 & 0.28 & 246.64 & 0.99 & $* *$ & 0.71 & $* *$ & $* *$ & $* *$ & & 231.59 \\
\hline$\%$ St Dev & 3.36 & 2.18 & 1.14 & 1.76 & 1.04 & 3.03 & 0.45 & $* *$ & 1.39 & $* *$ & $* *$ & ** & & 1.13 \\
\hline $\begin{array}{l}\text { NDT = not determined. Sampl } \\
\text { NS - not sampled/no sample } \\
\text { *the laboratory reporting is u } \\
\text { **-no standard deviation for } \\
\star * * \text { - concentration determin }\end{array}$ & $\begin{array}{l}\text { isted of I } \\
\text { place of } \\
\text { s where } \\
\text { vimetric }\end{array}$ & $\begin{array}{l}\text { ge rocks. } \\
\text { on-detect } \\
5 \mathrm{mg} / \mathrm{kg} \\
\text { y as desc }\end{array}$ & $\begin{array}{l}\text { alues } \\
\text { L was us } \\
\text { oed in the }\end{array}$ & $\begin{array}{l}\text { in calcu } \\
\text { ext. }\end{array}$ & tions. & & & & & & & & & \\
\hline
\end{tabular}


Table C17. Range 20-3 Wet Sieve

\begin{tabular}{|c|c|c|c|c|c|c|c|c|c|c|c|c|c|c|}
\hline Separation Procedure & \multicolumn{14}{|c|}{ Metals (mg/kg) } \\
\hline & $\mathrm{Pb}$ & $\mathrm{Cr}$ & $\mathrm{Cu}$ & $\mathrm{Ni}$ & $\mathrm{Zn}$ & $\mathrm{Fe}$ & $\mathrm{Mn}$ & Mo & $\mathrm{V}$ & $\mathrm{Sb}$ & W & As & $\mathrm{Ca}$ & U \\
\hline WS_>4_20_3 rep. 1 & NDT & NDT & NDT & NDT & NDT & NDT & NDT & NDT & NDT & NDT & NDT & NDT & NS & $* * *$ \\
\hline WS_>4_20_3 rep. 2 & NDT & NDT & NDT & NDT & NDT & NDT & NDT & NDT & NDT & NDT & NDT & NDT & NS & \\
\hline WS_>4_20_3 rep. 3 & NDT & NDT & NDT & NDT & NDT & NDT & NDT & NDT & NDT & NDT & NDT & NDT & NS & \\
\hline \multicolumn{15}{|l|}{ Average } \\
\hline \multicolumn{15}{|l|}{ St dev } \\
\hline \multicolumn{15}{|l|}{ \% St Dev } \\
\hline WS_>10_20_3 rep.1 & 13.28 & 12.14 & 16.91 & 11.42 & 22.14 & 6247.00 & 242.00 & $<5 *$ & 26.55 & $<5^{*}$ & 11.63 & $<5^{*}$ & NS & 3055.00 \\
\hline WS_>10_20_3 rep. 2 & 13.06 & 12.85 & 16.58 & 12.49 & 23.75 & 6924.00 & 255.40 & $<5$ & 26.43 & $<5$ & 10.25 & $<5$ & NS & 2659.00 \\
\hline WS_>10_20_3 rep. 3 & 13.44 & 10.84 & 15.15 & 10.11 & 19.92 & 5570.00 & 237.20 & $<5$ & 23.38 & $<5$ & $<5$ & $<5$ & NS & 2702.00 \\
\hline Average & 13.26 & 11.94 & 16.21 & 11.34 & 21.94 & 6247.00 & 244.87 & $<5$ & 25.45 & $<5$ & 10.94 & $<5$ & & 2805.33 \\
\hline St dev & 0.19 & 1.02 & 0.94 & 1.19 & 1.92 & 677.00 & 9.43 & ** & 1.80 & $* *$ & 0.98 & $* *$ & & 217.28 \\
\hline$\%$ St Dev & 1.44 & 8.53 & 5.77 & 10.51 & 8.77 & 10.84 & 3.85 & $* *$ & 7.06 & $* *$ & 8.92 & $* *$ & & 7.75 \\
\hline WS_>50_20_3 rep. 1 & 32.60 & 24.53 & 52.50 & 12.48 & 21.49 & 5782.00 & 205.90 & $<5^{*}$ & 43.75 & $<5 *$ & $<5 *$ & $<5 *$ & NS & 19820.00 \\
\hline WS_>50_20_3 rep. 2 & 33.65 & 25.28 & 53.31 & 13.22 & 23.71 & 6431.00 & 210.20 & $<5$ & 45.45 & $<5$ & $<5$ & $<5$ & NS & 19800.00 \\
\hline WS_>50_20_3 rep. 3 & 32.47 & 24.19 & 52.75 & 13.25 & 22.99 & 6495.00 & 219.70 & $<5$ & 45.34 & $<5$ & $<5$ & $<5$ & NS & 19620.00 \\
\hline Average & 32.91 & 24.67 & 52.85 & 12.98 & 22.73 & 6236.00 & 211.93 & $<5$ & 44.85 & $<5$ & $<5$ & $<5$ & & 19746.67 \\
\hline St dev & 0.65 & 0.56 & 0.41 & 0.44 & 1.13 & 394.48 & 7.06 & $* *$ & 0.95 & $* *$ & $* *$ & ** & & 110.15 \\
\hline$\%$ St Dev & 1.97 & 2.26 & 0.78 & 3.36 & 4.98 & 6.33 & 3.33 & $* *$ & 2.12 & $* *$ & $* *$ & $* *$ & & 0.56 \\
\hline WS_<50_20_3 rep.1 & 32.54 & 23.68 & 66.69 & 11.73 & 25.39 & 5949.00 & 199.60 & $<5^{*}$ & 43.41 & $<5^{*}$ & 18.64 & $<5^{*}$ & NS & 18640.00 \\
\hline WS_<50_20_3 rep. 2 & 31.68 & 23.70 & 66.91 & 11.28 & 24.38 & 5876.00 & 199.10 & $<5$ & 43.22 & $<5$ & 19.15 & $<5$ & NS & 18850.00 \\
\hline WS_<50_20_3 rep. 3 & 29.99 & 23.81 & 67.51 & 11.86 & 26.91 & 6379.00 & 203.10 & $<5$ & 43.90 & $<5$ & 14.12 & $<5$ & NS & 18580.00 \\
\hline Average & 31.40 & 23.73 & 67.04 & 11.62 & 25.56 & 6068.00 & 200.60 & $<5$ & 43.51 & $<5$ & 17.30 & $<5$ & & 18690.00 \\
\hline St dev & 1.30 & 0.07 & 0.42 & 0.30 & 1.27 & 271.80 & 2.18 & $* *$ & 0.35 & $* *$ & 2.77 & $* *$ & & 141.77 \\
\hline$\%$ St Dev & 4.13 & 0.29 & 0.63 & 2.62 & 4.98 & 4.48 & 1.09 & $* *$ & 0.81 & $* *$ & 16.00 & $* *$ & & 0.76 \\
\hline \multicolumn{15}{|c|}{$\begin{array}{l}\text { NDT = not determined. Sample consisted of large rocks. } \\
\text { NS - not sampled/no sample } \\
* \text { the laboratory reporting is used in place of non-detect values } \\
* * \text {-no standard deviation for samples where }<5 \mathrm{mg} / \mathrm{kg} \text { IDL was used in calculations. } \\
* * * \text { - concentration determined gravimetrically as described in the text. }\end{array}$} \\
\hline
\end{tabular}


Table C18. Retention Pond Wet Sieve Separation

\begin{tabular}{|c|c|c|c|c|c|c|c|c|c|c|c|c|c|c|}
\hline Separation Procedure & \multicolumn{14}{|c|}{ Metals (mg/kg) } \\
\hline & $\mathrm{Pb}$ & $\mathrm{Cr}$ & $\mathrm{Cu}$ & $\mathrm{Ni}$ & $\mathrm{Zn}$ & $\mathrm{Fe}$ & $\mathrm{Mn}$ & Mo & $\mathrm{V}$ & $\mathrm{Sb}$ & W & As & $\mathrm{Ca}$ & $U$ \\
\hline WS_>20_RP rep. 1 & 12.07 & 12.49 & 26.53 & $<5 *$ & 72.92 & 7692.00 & 202.60 & $<5 *$ & 17.99 & $<5 *$ & $<5^{*}$ & $<5 *$ & NS & 47.54 \\
\hline WS_>20_RP rep. 2 & 13.03 & 12.20 & 26.99 & $<5$ & 73.65 & 6971.00 & 197.70 & $<5$ & 16.50 & $<5$ & $<5$ & $<5$ & NS & 69.90 \\
\hline WS_>20_RP rep. 3 & 11.40 & 11.70 & 25.87 & $<5$ & 71.83 & 6560.00 & 192.40 & $<5$ & 15.24 & $<5$ & $<5$ & $<5$ & NS & 77.27 \\
\hline Average & 12.17 & 12.13 & 26.46 & $<5$ & 72.80 & 7074.33 & 197.57 & $<5$ & 16.58 & $<5$ & $<5$ & $<5$ & & 64.90 \\
\hline St dev & 0.82 & 0.40 & 0.56 & $* *$ & 0.92 & 573.03 & 5.10 & $* *$ & 1.38 & $* *$ & $* *$ & $* *$ & & 15.48 \\
\hline$\%$ St Dev & 6.73 & 3.29 & 2.13 & $* *$ & 1.26 & 8.10 & 2.58 & $* *$ & 8.30 & $* *$ & $\star *$ & $* *$ & & 23.85 \\
\hline WS_>60_RP rep. 1 & 12.47 & 15.08 & 16.81 & $<5 *$ & 77.37 & 7551.00 & 264.40 & $<5 *$ & 19.26 & $<5 *$ & $<5 *$ & $<5 *$ & NS & 294.90 \\
\hline WS_>60_RP rep. 2 & 11.38 & 15.67 & 17.61 & $<5$ & 100.90 & 7734.00 & 271.80 & $<5$ & 19.94 & $<5$ & $<5$ & $<5$ & NS & 306.20 \\
\hline WS_>60_RP rep. 3 & 13.06 & 15.67 & 17.63 & $<5$ & 90.80 & 8042.00 & 277.60 & $<5$ & 20.54 & $<5$ & $<5$ & $<5$ & NS & 301.50 \\
\hline Average & 12.30 & 15.47 & 17.35 & $<5$ & 89.69 & 7775.67 & 271.27 & $<5$ & 19.91 & $<5$ & $<5$ & $<5$ & & 300.87 \\
\hline St dev & 0.85 & 0.34 & 0.47 & ** & 11.80 & 248.14 & 6.62 & ** & 0.64 & ** & ** & ** & & 5.68 \\
\hline$\%$ St Dev & 6.93 & 2.20 & 2.70 & $* *$ & 13.16 & 3.19 & 2.44 & ** & 3.22 & ** & ** & ** & & 1.89 \\
\hline WS_>120_RP rep. 1 & 52.74 & 18.32 & 86.64 & 10.26 & 69.52 & 8941.00 & 279.60 & $<5 *$ & 26.10 & $<5 *$ & $<5 *$ & $<5^{*}$ & NS & 1494.00 \\
\hline WS_>120_RP rep. 2 & 50.40 & 17.82 & 87.63 & $<5$ & 67.99 & 8593.00 & 270.50 & $<5$ & 25.60 & $<5$ & $<5$ & $<5$ & NS & 1509.00 \\
\hline WS_>120_RP rep. 3 & 52.50 & 18.47 & 86.03 & 10.21 & 69.91 & 9114.00 & 280.00 & $<5$ & 26.14 & $<5$ & 17.41 & $<5$ & NS & 1544.00 \\
\hline Average & 51.88 & 18.20 & 86.77 & 10.24 & 69.14 & 8882.67 & 276.70 & $<5$ & 25.95 & $<5$ & 17.41 & $<5$ & & 1515.67 \\
\hline St dev & 1.29 & 0.34 & 0.81 & 0.04 & 1.01 & 265.35 & 5.37 & $* *$ & 0.30 & $* *$ & * & $\star *$ & & 25.66 \\
\hline \% St Dev & 2.48 & 1.87 & 0.93 & 0.35 & 1.47 & 2.99 & 1.94 & ** & 1.16 & $* *$ & * & ** & & 1.69 \\
\hline WS_>400_RP & 13.72 & 24.99 & 45.45 & 22.03 & 87.89 & 16950.00 & 424.60 & $<5 *$ & 45.44 & $<5^{*}$ & $<5 *$ & $<5 *$ & NS & 132.70 \\
\hline WS_>400_RP & 13.06 & 29.53 & 47.44 & 26.25 & 102.00 & 20260.00 & 500.00 & $<5$ & 56.44 & $<5$ & $<5$ & $<5$ & NS & 19.25 \\
\hline WS_>400_RP rep. 3 & 12.89 & 26.29 & 41.90 & 23.33 & 92.74 & 18280.00 & 451.70 & $<5$ & 50.06 & $<5$ & $<5$ & $<5$ & NS & 79.70 \\
\hline Average & 13.22 & 26.94 & 44.93 & 23.87 & 94.21 & 18496.67 & 458.77 & $<5$ & 50.65 & $<5$ & $<5$ & $<5$ & & 77.22 \\
\hline St dev & 0.44 & 2.34 & 2.81 & 2.16 & 7.17 & 1665.60 & 38.19 & ** & 5.52 & ** & ** & ** & & 56.77 \\
\hline \% St Dev & 3.32 & 8.68 & 6.25 & 9.05 & 7.61 & 9.00 & 8.33 & $* *$ & 10.91 & $* *$ & $* *$ & $* *$ & & 73.51 \\
\hline WS_<400_RP rep. 1 & 21.10 & 19.30 & 70.60 & 17.19 & 73.99 & 12110.00 & 490.90 & $<5 *$ & 35.12 & $<5 *$ & $<5 *$ & $<5^{*}$ & NS & 1314.00 \\
\hline WS_<400_RP rep. 2 & 21.54 & 21.54 & 74.81 & 19.11 & 81.43 & 13610.00 & 517.30 & $<5$ & 38.22 & $<5$ & $<5$ & $<5$ & NS & 1272.00 \\
\hline WS_<400_RP rep. 3 & 21.15 & 19.52 & 73.10 & 17.37 & 75.71 & 11950.00 & 489.40 & $<5$ & 36.07 & $<5$ & $<5$ & $<5$ & NS & 1325.00 \\
\hline Average & 21.26 & 20.12 & 72.84 & 17.89 & 77.04 & 12556.67 & 499.20 & $<5$ & 36.47 & $<5$ & $<5$ & $<5$ & & 1303.67 \\
\hline St dev & 0.24 & 1.23 & 2.12 & 1.06 & 3.90 & 915.71 & 15.69 & $* *$ & 1.59 & $* *$ & $* *$ & $* *$ & & 27.97 \\
\hline \% St Dev & 1.13 & 6.14 & 2.91 & 5.93 & 5.06 & 7.29 & 3.14 & $* *$ & 4.35 & $* *$ & $\star *$ & $* *$ & & 2.15 \\
\hline
\end{tabular}




\section{Appendix D. Heavy Liquid Density Separation}


Table D1. Background 1 HLDS

\begin{tabular}{|c|c|c|c|c|c|c|c|c|c|c|c|c|c|c|}
\hline \multirow[t]{2}{*}{ Separation Process } & \multicolumn{14}{|c|}{ Metals (mg/kg) } \\
\hline & $\mathrm{Pb}$ & $\mathrm{Cr}$ & $\mathrm{Cu}$ & $\mathrm{Ni}$ & $\mathrm{Zn}$ & $\mathrm{Fe}$ & $\mathrm{Mn}$ & Mo & V & $\mathrm{Sb}$ & W & As & $\mathrm{Ca}$ & $\mathrm{U}$ \\
\hline HLDS_B_BGGEL_1 rep. 1 & $<5$ & $<5$ & $<5$ & $<5$ & 20.61 & 6187.00 & 221.20 & $<5$ & $<5$ & $<5$ & 98.52 & $<5$ & NS & $<5$ \\
\hline HLDS_B_BGGEL_1 rep. 2 & $<5$ & $<5$ & $<5$ & $<5$ & $<5$ & 4566.00 & 249.70 & $<5$ & $<5$ & $<5$ & 91.38 & $<5$ & NS & $<5$ \\
\hline HLDS_B_BGGEL_ 1 rep. 3 & $<5$ & $<5$ & $<5$ & $<5$ & $<5$ & 5951.00 & 236.50 & $<5$ & $<5$ & $<5$ & 64.94 & $<5$ & NS & $<5$ \\
\hline Average & $<5$ & $<5$ & $<5$ & $<5$ & 20.61 & 5568.00 & 235.80 & $<5$ & $<5$ & $<5$ & 84.95 & $<5$ & & $<5$ \\
\hline St dev & $*$ & * & * & * & * & 875.74 & 14.26 & * & * & * & 17.69 & * & * & * \\
\hline$\%$ St Dev & * & * & * & * & * & 15.73 & 6.05 & * & * & * & 20.83 & * & * & * \\
\hline HLDS_F_BGGEL_1 rep. 1 & $<5$ & 40.15 & $<5$ & $<5$ & 27.25 & 3109.00 & 161.50 & $<5$ & $<5$ & $<5$ & 20620.00 & $<5$ & NS & $<5$ \\
\hline HLDS_F_BGGEL_1 rep. 2 & $<5$ & 43.27 & $<5$ & $<5$ & 24.89 & 2123.00 & 142.80 & $<5$ & $<5$ & $<5$ & 23250.00 & $<5$ & NS & $<5$ \\
\hline HLDS_F_BGGEL_1 rep. 3 & $<5$ & 38.07 & $<5$ & $<5$ & 21.98 & 1466.00 & 131.90 & $<5$ & $<5$ & $<5$ & 21320.00 & $<5$ & NS & $<5$ \\
\hline Average & $<5$ & 40.50 & $<5$ & $<5$ & 24.71 & 2232.67 & 145.40 & $<5$ & $<5$ & $<5$ & 21730.00 & $<5$ & & $<5$ \\
\hline St dev & * & 2.62 & * & * & 2.64 & 826.97 & 14.97 & * & * & $*$ & 1362.09 & $\star$ & & $*$ \\
\hline$\%$ St Dev & * & 6.46 & * & * & 10.68 & 37.04 & 10.30 & * & * & * & 6.27 & * & & * \\
\hline HLDS_S_BGGEL_1 rep. 1 & $<5$ & 16.03 & $<5$ & $<5$ & 19.50 & 3151.00 & 154.90 & $<5$ & $<5$ & $<5$ & 6930.00 & $<5$ & NS & $<5$ \\
\hline HLDS_S_BGGEL_1 rep. 2 & $<5$ & 13.50 & $<5$ & $<5$ & 18.25 & 3189.00 & 156.30 & $<5$ & $<5$ & $<5$ & 5327.00 & $<5$ & NS & $<5$ \\
\hline HLDS_S_BGGEL_1 rep. 3 & $<5$ & 16.40 & $<5$ & $<5$ & 18.18 & 2879.00 & 152.70 & $<5$ & $<5$ & $<5$ & 7496.00 & $<5$ & NS & $<5$ \\
\hline Average & $<5$ & 15.31 & $<5$ & $<5$ & 18.64 & 3073.00 & 154.63 & $<5$ & $<5$ & $<5$ & 6584.33 & $<5$ & & $<5$ \\
\hline St dev & * & 1.58 & * & * & 0.74 & 169.08 & 1.81 & * & * & * & 1125.06 & * & & * \\
\hline$\%$ St Dev & * & 10.31 & * & * & 3.98 & 5.50 & 1.17 & * & * & * & 17.09 & * & & * \\
\hline
\end{tabular}


Table D2. Background 2 HLDS

\begin{tabular}{|c|c|c|c|c|c|c|c|c|c|c|c|c|c|c|}
\hline Separation Procedure & \multicolumn{14}{|c|}{ Metals (mg/kg) } \\
\hline HLDS_B_BGGEL_2 rep. 1 & 15.86 & ND & ND & ND & ND & 3932.00 & 303.00 & ND & ND & ND & 79.45 & ND & NS & $\overline{N D}$ \\
\hline HLDS_B_BGGEL_ 2 rep. 3 & NR & NR & NR & NR & NR & NR & NR & NR & NR & NR & NR & NR & NR & NR \\
\hline Average & 15.86 & & & & & 3194.00 & 269.15 & & & & 68.05 & & & \\
\hline HLDS_F_BGGEL_2 rep. 1 & ND & 13.12 & ND & 10.78 & 23.82 & 6406.00 & 218.40 & ND & 13.07 & ND & 2532.00 & ND & NS & ND \\
\hline HLDS_F_BGGEL_2 rep. 2 & ND & 14.13 & ND & 11.45 & 23.89 & 6544.00 & 220.10 & ND & 12.87 & ND & 3370.00 & ND & NS & ND \\
\hline HLDS_F_BGGEL_2 rep. 3 & ND & 12.71 & ND & 10.01 & 22.10 & 6002.00 & 211.30 & ND & 12.08 & ND & 2687.00 & ND & NS & ND \\
\hline Average & & 13.32 & & 10.75 & 23.27 & 6317.33 & 216.60 & & 12.67 & & 2863.00 & & & \\
\hline St dev & & 0.73 & & 0.72 & 1.01 & 281.67 & 4.67 & & 0.52 & & 445.86 & & & \\
\hline Average & & 10.84 & & 10.42 & 22.85 & 6047.00 & 203.60 & & 11.59 & & 1305.00 & & & \\
\hline St dev & & & & & 2.06 & 659.10 & 24.98 & & 1.02 & & 46.81 & & & \\
\hline$\%$ St Dev & & & & & \begin{tabular}{|l|}
9.01 \\
\end{tabular} & 10.90 & 12.27 & & 8.81 & & \begin{tabular}{|l|}
3.59 \\
\end{tabular} & & & \\
\hline $\begin{array}{l}\mathrm{ND}=\text { non detect } \\
\mathrm{NS}=\text { no sample } \\
*=\text { no standard deviation }\end{array}$ & 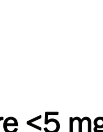 & 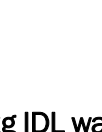 & & & & & & & & & & & & \\
\hline
\end{tabular}


Table D3. Background 3 HLDS

\begin{tabular}{|c|c|c|c|c|c|c|c|c|c|c|c|c|c|c|}
\hline \multirow[t]{2}{*}{ Separation Procedure } & \multicolumn{14}{|c|}{ Metals (mg/kg) } \\
\hline & $\mathrm{Pb}$ & $\mathrm{Cr}$ & $\mathrm{Cu}$ & $\mathrm{Ni}$ & $\mathrm{Zn}$ & $\mathrm{Fe}$ & $\mathrm{Mn}$ & Mo & $\mathrm{V}$ & $\mathrm{Sb}$ & W & As & $\mathrm{Ca}$ & $\mathrm{U}$ \\
\hline HLDS_B_BGGEL_3 rep. 1 & 23.20 & ND & ND & ND & 32.88 & 15310.00 & 369.20 & ND & 51.28 & ND & 305.00 & ND & NS & ND \\
\hline HLDS_B_BGGEL_3 rep. 2 & 22.66 & 21.25 & ND & ND & 31.83 & 15350.00 & 375.20 & ND & 51.01 & ND & 272.70 & ND & NS & ND \\
\hline HLDS_B_BGGEL_3 rep. 3 & 21.44 & ND & ND & ND & 22.08 & 9015.00 & 329.50 & ND & 31.27 & ND & 373.90 & ND & NS & ND \\
\hline Average & 22.43 & 21.25 & & & 28.93 & 13225.00 & 357.97 & & 44.52 & & 317.20 & & & \\
\hline St dev & 0.90 & & & & 5.96 & 3646.02 & 24.83 & & 11.48 & & 51.69 & & & \\
\hline$\%$ St Dev & 4.02 & & & & 20.59 & 27.57 & 6.94 & & 25.78 & & 16.30 & & & \\
\hline HLDS_F_BGGEL_3 rep. 1 & ND & 19.90 & ND & 13.09 & 27.58 & 6148.00 & 219.50 & ND & 13.63 & ND & 6602.00 & ND & NS & ND \\
\hline HLDS_F_BGGEL_3 rep. 2 & ND & 19.64 & ND & 11.40 & 27.37 & 6045.00 & 220.60 & ND & 13.93 & ND & 6457.00 & ND & NS & ND \\
\hline HLDS_F_BGGEL_3 rep. 3 & ND & 21.83 & ND & 11.33 & 28.38 & 5461.00 & 216.60 & ND & 13.55 & ND & 8839.00 & ND & NS & ND \\
\hline Average & & 20.46 & & 11.94 & 27.78 & 5884.67 & 218.90 & & 13.70 & & 7299.33 & & & \\
\hline St dev & & 1.20 & & 1.00 & 0.53 & 370.50 & 2.07 & & 0.20 & & 1335.36 & & & \\
\hline$\%$ St Dev & & 5.85 & & 8.35 & 1.92 & 6.30 & 0.94 & & 1.46 & & 18.29 & & & \\
\hline HLDS_S_BGGEL_3 rep.1 & ND & 14.13 & ND & 10.56 & 26.66 & 7468.00 & 196.50 & ND & 16.43 & ND & 979.30 & ND & NS & ND \\
\hline HLDS_S_BGGEL_3 rep. 2 & ND & 11.44 & ND & ND & 23.84 & 6282.00 & 185.50 & ND & 14.28 & ND & 1054.00 & ND & NS & ND \\
\hline HLDS_S_BGGEL_3 rep. 3 & ND & 13.03 & ND & 10.41 & 26.33 & 7383.00 & 196.10 & ND & 16.79 & ND & 789.90 & ND & NS & ND \\
\hline Average & & 12.87 & & 10.49 & 25.61 & 7044.33 & 192.70 & & 15.83 & & 941.07 & & & \\
\hline St dev & & 1.35 & & 0.11 & 1.54 & 661.57 & 6.24 & & 1.36 & & 136.14 & & & \\
\hline$\%$ St Dev & & 10.51 & & 1.01 & 6.02 & 9.39 & 3.24 & & 8.57 & & 14.47 & & & \\
\hline
\end{tabular}


Table D4. Background 4 HLDS

\begin{tabular}{|c|c|c|c|c|c|c|c|c|c|c|c|c|c|c|}
\hline \multirow[t]{2}{*}{ Separation Procedure } & \multicolumn{14}{|c|}{ Metals (mg/kg) } \\
\hline & $\mathrm{Pb}$ & $\mathrm{Cr}$ & $\mathrm{Cu}$ & $\mathrm{Ni}$ & $\mathrm{Zn}$ & $\mathrm{Fe}$ & $\mathrm{Mn}$ & Mo & $\mathrm{V}$ & $\mathrm{Sb}$ & w & As & $\mathrm{Ca}$ & $\mathrm{U}$ \\
\hline HLDS_B_BGGEL_4 rep. 1 & 18.96 & ND & ND & ND & 14.33 & 5834.00 & 370.50 & ND & 23.00 & ND & 160.00 & ND & NS & ND \\
\hline HLDS_B_BGGEL_4 rep. 2 & 26.44 & ND & 11.91 & 10.72 & 19.33 & 7073.00 & 436.50 & ND & 29.36 & ND & 118.30 & ND & NS & ND \\
\hline HLDS_B_BGGEL_4 rep. 3 & NR & NR & NR & NR & NR & NR & NR & NR & NR & NR & NR & NR & NR & NR \\
\hline Average & 22.70 & & 11.91 & 10.72 & 16.83 & 6453.50 & 403.50 & & 26.18 & & 139.15 & & & \\
\hline St dev & 5.29 & & & & 3.54 & 876.11 & 46.67 & & 4.50 & & 29.49 & & & \\
\hline$\%$ St Dev & 23.30 & & & & 21.01 & 13.58 & 11.57 & & 17.18 & & 21.19 & & & \\
\hline HLDS_F_BGGEL_4 rep. 1 & ND & ND & ND & ND & 14.68 & 3464.00 & 151.20 & ND & ND & ND & 1541.00 & ND & NS & ND \\
\hline HLDS_F_BGGEL_4 rep. 2 & ND & 11.93 & ND & ND & 21.80 & 4894.00 & 174.90 & $\mathrm{ND}$ & 10.19 & ND & 2121.00 & ND & NS & ND \\
\hline HLDS_F_BGGEL_4 rep. 3 & ND & 10.79 & ND & ND & 19.72 & 4403.00 & 170.90 & $\mathrm{ND}$ & ND & ND & 2369.00 & ND & NS & ND \\
\hline Average & & 11.36 & & & 18.73 & 4253.67 & 165.67 & & 10.19 & & 2010.33 & & & \\
\hline St dev & & 0.81 & & & 3.66 & 726.60 & 12.69 & & & & 424.95 & & & \\
\hline \% St Dev & & 7.10 & & & 19.54 & 17.08 & 7.66 & & & & 21.14 & & & \\
\hline HLDS_S_BGGEL_4 rep. 1 & ND & 15.87 & ND & ND & 19.60 & 1908.00 & 112.70 & $\mathrm{ND}$ & ND & ND & 7799.00 & ND & NS & ND \\
\hline HLDS_S_BGGEL_4 rep. 2 & ND & 17.97 & ND & ND & 18.99 & 1908.00 & 119.10 & ND & ND & ND & 9004.00 & ND & NS & ND \\
\hline HLDS_S_BGGEL_4 rep. 3 & ND & 16.63 & ND & ND & 18.33 & 1884.00 & 115.30 & ND & ND & ND & 7849.00 & ND & NS & ND \\
\hline Average & & 16.82 & & & 18.97 & 1900.00 & 115.70 & & & & 8217.33 & & & \\
\hline St dev & & 1.06 & & & 0.64 & 13.86 & 3.22 & & & & 681.73 & & & \\
\hline$\%$ St Dev & & 6.32 & & & 3.35 & 0.73 & 2.78 & & & & 8.30 & & & \\
\hline \multicolumn{15}{|c|}{$\begin{array}{l}\mathrm{ND}=\text { non detect } \\
\mathrm{NS}=\text { no sample } \\
*=\text { no standard deviation, samples where }<5 \mathrm{mg} / \mathrm{kg} \text { IDL was used in calculations } \\
\mathrm{NR}=\text { No replicate }\end{array}$} \\
\hline
\end{tabular}


Table D5. Catch Box 1 HLDS

\begin{tabular}{|c|c|c|c|c|c|c|c|c|c|c|c|c|c|c|}
\hline \multirow[t]{2}{*}{ Separation Procedure } & \multicolumn{14}{|c|}{ Metals (mg/kg) } \\
\hline & $\mathrm{Pb}$ & $\mathrm{Cr}$ & $\mathrm{Cu}$ & $\mathrm{Ni}$ & $\mathrm{Zn}$ & $\mathrm{Fe}$ & $\mathrm{Mn}$ & Mo & V & $\mathrm{Sb}$ & W & As & $\mathrm{Ca}$ & $\mathrm{U}$ \\
\hline HLDS_B_CB_1_A rep.1 & 28.14 & 27.94 & 46.18 & $<5$ & 32.87 & 11450.00 & 261.40 & $<5$ & 59.97 & $<5$ & 135.30 & $<5$ & 12420.00 & 20900.00 \\
\hline HLDS_B_CB_1_A rep. 2 & 26.52 & 29.33 & 45.49 & $<5$ & 36.52 & 13640.00 & 288.30 & $<5$ & 66.04 & $<5$ & 52.81 & $<5$ & 13600.00 & 20430.00 \\
\hline HLDS_B_CB_1_A rep. 3 & 27.47 & 25.50 & 42.86 & $<5$ & 32.84 & 9310.00 & 239.40 & $<5$ & 52.46 & $<5$ & 200.60 & $<5$ & 11980.00 & 20760.00 \\
\hline Average & 27.38 & 27.59 & 44.84 & $<5$ & 34.08 & 11466.67 & 263.03 & $<5$ & 59.49 & $<5$ & 129.57 & $<5$ & 12666.67 & 20696.67 \\
\hline St dev & 0.81 & 1.94 & 1.75 & & 2.12 & 2165.05 & 24.49 & & 6.80 & & 74.06 & & 837.70 & 241.32 \\
\hline$\%$ St Dev & 2.97 & 7.03 & 3.91 & & 6.21 & 18.88 & 9.31 & & 11.44 & & 57.16 & & 6.61 & 1.17 \\
\hline HLDS_F CB_1_A rep. 1 & $<5$ & $<5$ & $<5$ & $<5$ & 25.95 & 6486.00 & 153.90 & $<5$ & 13.26 & $<5$ & 879.80 & $<5$ & 12030.00 & 164.30 \\
\hline HLDS_F CB_1_A rep. 2 & $<5$ & $<5$ & $<5$ & $<5$ & 27.69 & 7002.00 & 163.50 & $<5$ & 13.00 & $<5$ & 814.80 & $<5$ & 12620.00 & 137.00 \\
\hline HLDS_F CB_1_A rep. 3 & $<5$ & $<5$ & $<5$ & $<5$ & 22.38 & 5490.00 & 136.20 & $<5$ & 10.84 & $<5$ & 1156.00 & $<5$ & 11860.00 & 163.40 \\
\hline Average & $<5$ & $<5$ & $<5$ & $<5$ & 25.34 & 6326.00 & 151.20 & $<5$ & 12.37 & $<5$ & 950.20 & $<5$ & 12170.00 & 154.90 \\
\hline St dev & & & & & 2.71 & 768.59 & 13.85 & & 1.33 & & 181.17 & & 398.87 & 15.51 \\
\hline$\%$ St Dev & & & & & 10.68 & 12.15 & 9.16 & & 10.74 & & 19.07 & & 3.28 & 10.01 \\
\hline HLDS_S_CB_1_A rep.1 & $<5$ & $<5$ & $<5$ & $<5$ & 10.77 & 2534.00 & 78.99 & $<5$ & $<5$ & $<5$ & 2143.00 & $<5$ & 8686.00 & 156.90 \\
\hline HLDS_S_CB_1_A rep. 2 & $<5$ & $<5$ & $<5$ & $<5$ & 12.39 & 2525.00 & 78.35 & $<5$ & $<5$ & $<5$ & 2014.00 & $<5$ & 8984.00 & 166.90 \\
\hline HLDS_S_CB_1_A rep. 3 & $<5$ & $<5$ & $<5$ & $<5$ & 10.19 & 2474.00 & 77.13 & $<5$ & $<5$ & $<5$ & 2088.00 & $<5$ & 8481.00 & 159.40 \\
\hline Average & $<5$ & $<5$ & $<5$ & $<5$ & 11.12 & 2511.00 & 78.16 & $<5$ & $<5$ & $<5$ & 2081.67 & $<5$ & 8717.00 & 161.07 \\
\hline St dev & & & & & 1.14 & 32.36 & 0.94 & & & & 64.73 & & 252.93 & 5.20 \\
\hline$\%$ St Dev & & & & & 10.26 & 1.29 & 1.21 & & & & 3.11 & & 2.90 & 3.23 \\
\hline HLDS_B_CB_1_B rep.1 & 11.88 & 14.66 & 22.11 & $<5$ & 28.22 & 8610.00 & 254.40 & $<5$ & 33.79 & $<5$ & 188.70 & $<5$ & 10740.00 & 8412.00 \\
\hline HLDS_B_CB_1_B rep. 2 & 10.77 & 14.09 & 22.21 & $<5$ & 29.34 & 9106.00 & 254.30 & $<5$ & 34.31 & $<5$ & 125.30 & $<5$ & 10640.00 & 8215.00 \\
\hline HLDS_B_CB_1_B rep. 3 & 11.27 & 14.46 & 21.94 & $<5$ & 30.63 & 9342.00 & 260.20 & $<5$ & 35.88 & $<5$ & 144.60 & $<5$ & 10910.00 & 8049.00 \\
\hline Average & 11.31 & 14.40 & 22.09 & $<5$ & 29.40 & 9019.33 & 256.30 & $<5$ & 34.66 & $<5$ & 152.87 & $<5$ & 10763.33 & 8225.33 \\
\hline St dev & 0.56 & 0.29 & 0.14 & & 1.21 & 373.62 & 3.38 & & 1.09 & & 32.50 & & 136.50 & 181.72 \\
\hline$\%$ St Dev & 4.92 & 2.01 & 0.62 & & 4.10 & 4.14 & 1.32 & & 3.14 & & 21.26 & & 1.27 & 2.21 \\
\hline HLDS_F_CB_1_B rep. 1 & $<5$ & $<5$ & $<5$ & $<5$ & 22.27 & 5627.00 & 144.10 & $<5$ & 13.79 & $<5$ & 1117.00 & $<5$ & 10400.00 & 359.40 \\
\hline HLDS_F_CB_1_B rep. 2 & $<5$ & $<5$ & $<5$ & $<5$ & 22.33 & 5584.00 & 143.60 & $<5$ & 13.61 & $<5$ & 963.80 & $<5$ & 10050.00 & 358.30 \\
\hline HLDS_F_CB_1_B rep. 3 & $<5$ & $<5$ & $<5$ & $<5$ & 22.82 & 5763.00 & 146.00 & $<5$ & 13.60 & $<5$ & 943.10 & $<5$ & 10100.00 & 362.40 \\
\hline Average & $<5$ & $<5$ & $<5$ & $<5$ & 22.47 & 5658.00 & 144.57 & $<5$ & 13.67 & $<5$ & 1007.97 & $<5$ & 10183.33 & 360.03 \\
\hline St dev & & & & & 0.30 & 93.44 & 1.27 & & 0.11 & & 94.99 & & 189.30 & 2.12 \\
\hline$\%$ St Dev & & & & & 1.34 & 1.65 & 0.88 & & 0.78 & & 9.42 & & 1.86 & 0.59 \\
\hline
\end{tabular}




\begin{tabular}{|c|c|c|c|c|c|c|c|c|c|c|c|c|c|c|}
\hline \multirow[t]{2}{*}{ Separation Procedure } & \multicolumn{14}{|c|}{ Metals (mg/kg) } \\
\hline & $\mathrm{Pb}$ & $\mathrm{Cr}$ & $\mathrm{Cu}$ & $\mathrm{Ni}$ & $\mathrm{Zn}$ & $\mathrm{Fe}$ & $\mathrm{Mn}$ & Mo & $\mathrm{V}$ & $\mathrm{Sb}$ & W & As & $\mathrm{Ca}$ & $\mathrm{U}$ \\
\hline HLDS_S_CB_1_B rep.1 & $<5$ & $<5$ & $<5$ & $<5$ & 23.03 & 6029.00 & 162.00 & $<5$ & 14.03 & $<5$ & 452.00 & $<5$ & 12060.00 & 153.60 \\
\hline HLDS_S_CB_1_B rep. 2 & $<5$ & $<5$ & $<5$ & $<5$ & 22.65 & 5953.00 & 162.70 & $<5$ & 14.81 & $<5$ & 536.00 & $<5$ & 12370.00 & 154.90 \\
\hline HLDS_S_CB_1_B rep. 3 & $<5$ & $<5$ & $<5$ & $<5$ & 22.97 & 6055.00 & 162.60 & $<5$ & 14.54 & $<5$ & 503.80 & $<5$ & 12300.00 & 145.70 \\
\hline Average & $<5$ & $<5$ & $<5$ & $<5$ & 22.88 & 6012.33 & 162.43 & $<5$ & 14.46 & $<5$ & 497.27 & $<5$ & 12243.33 & 151.40 \\
\hline St dev & & & & & 0.20 & 53.00 & 0.38 & & 0.40 & & 42.38 & & 162.58 & 4.98 \\
\hline \% St Dev & & & & & 0.89 & 0.88 & 0.23 & & 2.74 & & 8.52 & & 1.33 & 3.29 \\
\hline HLDS_B_CB_1_C rep.1 & 12.72 & 23.47 & 28.80 & 14.29 & 50.90 & 15600.00 & 402.00 & $<5$ & 59.97 & $<5$ & 49.01 & $<5$ & 11750.00 & 9099.00 \\
\hline HLDS_B_CB_1_C rep. 2 & 13.39 & 23.14 & 28.60 & 14.46 & 53.09 & 16370.00 & 404.00 & $<5$ & 64.04 & $<5$ & 37.74 & $<5$ & 12140.00 & 8736.00 \\
\hline HLDS_B_CB_1_C rep. 3 & 14.44 & 23.05 & 28.14 & 14.53 & 52.81 & 16130.00 & 403.10 & $<5$ & 60.81 & $<5$ & 35.56 & $<5$ & 11790.00 & 8785.00 \\
\hline Average & 13.52 & 23.22 & 28.51 & 14.43 & 52.27 & 16033.33 & 403.03 & $<5$ & 61.61 & $<5$ & 40.77 & $<5$ & 11893.33 & 8873.33 \\
\hline St dev & 0.87 & 0.22 & 0.34 & 0.12 & 1.19 & 394.00 & 1.00 & & 2.15 & & 7.22 & & 214.55 & 196.96 \\
\hline$\%$ St Dev & 6.41 & 0.95 & 1.19 & 0.86 & 2.28 & 2.46 & 0.25 & & 3.49 & & 17.71 & & 1.80 & 2.22 \\
\hline HLDS_F_CB_1_C rep.1 & $<5$ & $<5$ & $<5$ & $<5$ & 16.16 & 3858.00 & 99.42 & $<5$ & $<5$ & $<5$ & 1576.00 & $<5$ & 7912.00 & 107.20 \\
\hline HLDS_F_CB_1_C rep. 2 & $<5$ & $<5$ & $<5$ & $<5$ & 15.95 & 3801.00 & 97.93 & $<5$ & $<5$ & $<5$ & 1588.00 & $<5$ & 7953.00 & 95.59 \\
\hline HLDS_F_CB_1_C rep. 3 & $<5$ & $<5$ & $<5$ & $<5$ & 15.61 & 3729.00 & 96.53 & $<5$ & $<5$ & $<5$ & 1155.00 & $<5$ & 7541.00 & 94.02 \\
\hline Average & $<5$ & $<5$ & $<5$ & $<5$ & 15.91 & 3796.00 & 97.96 & $<5$ & $<5$ & $<5$ & 1439.67 & $<5$ & 7802.00 & 98.94 \\
\hline St dev & & & & & 0.28 & 64.65 & 1.45 & & & & 246.60 & & 226.96 & 7.20 \\
\hline$\%$ St Dev & & & & & 1.74 & 1.70 & 1.48 & & & & 17.13 & & 2.91 & 7.28 \\
\hline HLDS_S_CB_1_C rep.1 & $<5$ & $<5$ & $<5$ & $<5$ & 25.04 & 6347.00 & 156.30 & $<5$ & 14.40 & $<5$ & 1297.00 & $<5$ & 12730.00 & 139.90 \\
\hline HLDS_S_CB_1_C rep. 2 & $<5$ & $<5$ & $<5$ & $<5$ & 25.75 & 6371.00 & 155.60 & $<5$ & 14.42 & $<5$ & 1292.00 & $<5$ & 12270.00 & 139.40 \\
\hline HLDS_S_CB_1_C rep. 3 & $<5$ & $<5$ & $<5$ & $<5$ & 24.96 & 6190.00 & 153.20 & $<5$ & 13.90 & $<5$ & 1154.00 & $<5$ & 12550.00 & 135.50 \\
\hline Average & $<5$ & $<5$ & $<5$ & $<5$ & 25.25 & 6302.67 & 155.03 & $<5$ & 14.24 & $<5$ & 1247.67 & $<5$ & 12516.67 & 138.27 \\
\hline St dev & & & & & 0.43 & 98.31 & 1.63 & & 0.29 & & 81.16 & & 231.80 & 2.41 \\
\hline \% St Dev & & & & & 1.72 & 1.56 & 1.05 & & 2.07 & & 6.50 & & 1.85 & 1.74 \\
\hline
\end{tabular}


Table D6. Soil mass, DU mass and \% total DU per density fraction for HLDS of Catch Box soils*

\begin{tabular}{|c|c|c|c|c|c|c|c|c|c|c|c|c|c|}
\hline \multirow[t]{2}{*}{$\begin{array}{c}\text { Size } \\
\text { Fraction }\end{array}$} & \multicolumn{5}{|c|}{$\begin{array}{l}\text { Soil Mass } \\
\text { (kg) }\end{array}$} & \multicolumn{5}{|c|}{ Mg of DU } & \multicolumn{3}{|c|}{ \% Total DU per Fraction } \\
\hline & CB 1 & CB 2 & CB 3 & Avg & stdev & CB 1 & CB 2 & CB 3 & Avg & stdev & CB 1 & CB 2 & СВ 3 \\
\hline Bottom & 0.01 & 0.02 & 0.01 & 0.01 & 0.01 & 62.99 & 357.60 & 154.42 & 191.67 & 150.80 & 77.41 & 84.80 & 90.27 \\
\hline Suspended & 0.04 & 0.02 & 0.04 & 0.03 & 0.01 & 6.11 & 13.96 & 7.85 & 9.31 & 4.13 & 7.51 & 3.31 & 4.59 \\
\hline Floating & 0.06 & 0.06 & 0.03 & 0.05 & 0.02 & 12.28 & 50.12 & 8.80 & 23.73 & 22.92 & 15.09 & 11.89 & 5.15 \\
\hline Total & 0.11 & 0.11 & 0.08 & 0.10 & & 81.38 & 421.69 & 171.07 & 224.71 & 176.38 & & & \\
\hline
\end{tabular}


Table D7. Catch Box 2 HLDS

\begin{tabular}{|c|c|c|c|c|c|c|c|c|c|c|c|c|c|c|}
\hline \multirow[t]{2}{*}{ Separation Procedure } & \multicolumn{14}{|c|}{ Metals (mg/kg) } \\
\hline & $\mathrm{Pb}$ & $\mathrm{Cr}$ & $\mathrm{Cu}$ & $\mathrm{Ni}$ & $\mathrm{Zn}$ & $\mathrm{Fe}$ & $\mathrm{Mn}$ & Mo & V & $\mathrm{Sb}$ & W & As & $\mathrm{Ca}$ & $\mathrm{U}$ \\
\hline HLDS_B_CB_2_A rep. 1 & 10.46 & 10.36 & 16.23 & $<5$ & 15.19 & 4013.00 & 119.80 & $<5$ & 20.23 & $<5$ & 633.70 & $<5$ & NS & 6881.00 \\
\hline HLDS_B_CB_2_A rep. 2 & 11.79 & 10.45 & 16.52 & $<5$ & 16.24 & 4196.00 & 123.70 & $<5$ & 20.92 & $<5$ & 576.80 & $<5$ & NS & 6955.00 \\
\hline HLDS_B_CB_2_A rep. 3 & 10.38 & $<5$ & 15.65 & $<5$ & 15.75 & 4041.00 & 116.90 & $<5$ & 20.13 & $<5$ & 583.60 & $<5$ & NS & 6462.00 \\
\hline Average & 10.88 & 10.41 & 16.13 & $<5$ & 15.73 & 4083.33 & 120.13 & $<5$ & 20.43 & $<5$ & 598.03 & $<5$ & & 6766.00 \\
\hline St dev & 0.79 & 0.06 & 0.44 & * & 0.53 & 98.57 & 3.41 & * & 0.43 & * & 31.07 & * & & 265.86 \\
\hline$\%$ St Dev & 7.28 & 0.61 & 2.75 & * & 3.34 & 2.41 & 2.84 & * & 2.11 & * & 5.20 & * & & 3.93 \\
\hline HLDS_F_CB_2_A rep. 1 & ND & 0.00 & ND & ND & 27.84 & 6659.00 & 166.40 & ND & 16.40 & ND & 1969.00 & ND & NS & 546.10 \\
\hline HLDS_F_CB_2_A rep. 2 & ND & 10.97 & ND & ND & 24.16 & 5628.00 & 153.20 & ND & 14.01 & ND & 3393.00 & ND & NS & 561.40 \\
\hline HLDS_F_CB_2_A rep. 3 & ND & 0.00 & ND & ND & 22.26 & 5048.00 & 142.70 & ND & 13.02 & ND & 2936.00 & ND & NS & 530.80 \\
\hline Average & & 3.66 & & & 24.75 & 5778.33 & 154.10 & & 14.48 & & 2766.00 & & & 546.10 \\
\hline St dev & & & & & 2.84 & 815.95 & 11.88 & & 1.74 & & 727.06 & & & 15.30 \\
\hline$\%$ St Dev & & & & & 11.46 & 14.12 & 7.71 & & 12.00 & & 26.29 & & & 2.80 \\
\hline HLDS_S_CB_2_A rep. 1 & ND & ND & 11.00 & ND & 30.04 & 7668.00 & 204.80 & ND & 20.67 & ND & 528.10 & ND & NS & 688.00 \\
\hline HLDS_S_CB_2_A rep. 2 & ND & ND & 11.34 & ND & 31.92 & 8283.00 & 213.20 & ND & 21.77 & ND & 439.10 & ND & NS & 690.30 \\
\hline HLDS_S_CB_2_A rep. 3 & ND & ND & 10.48 & ND & 27.71 & 7181.00 & 192.90 & ND & 19.61 & ND & 503.30 & ND & NS & 692.70 \\
\hline Average & & & 10.94 & & 29.89 & 7710.67 & 203.63 & & 20.68 & & 490.17 & & & 690.33 \\
\hline St dev & & & 0.43 & & 2.11 & 552.24 & 10.20 & & 1.08 & & 45.93 & & & 2.35 \\
\hline$\%$ St Dev & & & 3.96 & & 7.06 & 7.16 & 5.01 & & 5.22 & & 9.37 & & & 0.34 \\
\hline HLDS_B_CB_2_B rep.1 & 20.30 & 15.78 & 28.56 & $<5$ & 19.68 & 5658.00 & 154.80 & $<5$ & 33.14 & $<5$ & 285.40 & $<5$ & NS & 12780.00 \\
\hline HLDS_B_CB_2_B rep. 2 & 19.55 & 16.64 & 28.06 & $<5$ & 20.39 & 5932.00 & 158.10 & $<5$ & 33.67 & $<5$ & 262.00 & $<5$ & NS & 12570.00 \\
\hline HLDS_B_CB_2_B rep. 3 & 23.25 & 15.85 & 27.95 & $<5$ & 18.72 & 5436.00 & 151.80 & $<5$ & 32.87 & $<5$ & 312.30 & $<5$ & NS & 12910.00 \\
\hline Average & 21.03 & 16.09 & 28.19 & $<5$ & 19.60 & 5675.33 & 154.90 & $<5$ & 33.23 & $<5$ & 286.57 & $<5$ & & 12753.33 \\
\hline St dev & 1.96 & 0.48 & 0.33 & * & 0.84 & 248.45 & 3.15 & * & 0.41 & * & 25.17 & * & & 171.56 \\
\hline$\%$ St Dev & 9.30 & 2.97 & 1.15 & * & 4.28 & 4.38 & 2.03 & * & 1.22 & * & 8.78 & * & & 1.35 \\
\hline HLDS_F_CB_2_B rep. 1 & $<5$ & 5.00 & $<5$ & $<5$ & 24.14 & 5817.00 & 167.30 & $<5$ & 15.78 & $<5$ & 2022.00 & $<5$ & NS & 1058.00 \\
\hline HLDS_F_CB_2_B rep. 2 & $<5$ & 10.11 & $<5$ & $<5$ & 26.75 & 6139.00 & 172.20 & $<5$ & 15.79 & $<5$ & 2142.00 & $<5$ & NS & 992.10 \\
\hline HLDS_F_CB_2_B rep. 3 & $<5$ & 5.00 & $<5$ & $<5$ & 23.75 & 5523.00 & 158.40 & $<5$ & 15.42 & $<5$ & 2307.00 & $<5$ & NS & 939.60 \\
\hline Average & $<5$ & 6.70 & $<5$ & $<5$ & 24.88 & 5826.33 & 165.97 & $<5$ & 15.66 & $<5$ & 2157.00 & $<5$ & & 996.57 \\
\hline St dev & * & 2.95 & * & * & 1.63 & 308.11 & 7.00 & * & 0.21 & * & 143.09 & * & & 59.33 \\
\hline
\end{tabular}




\begin{tabular}{|c|c|c|c|c|c|c|c|c|c|c|c|c|c|c|}
\hline \multirow[t]{2}{*}{ Separation Procedure } & \multicolumn{14}{|c|}{ Metals (mg/kg) } \\
\hline & $\mathrm{Pb}$ & $\mathrm{Cr}$ & $\mathrm{Cu}$ & $\mathrm{Ni}$ & $\mathrm{Zn}$ & $\mathrm{Fe}$ & $\mathrm{Mn}$ & Mo & $\mathrm{V}$ & $\mathrm{Sb}$ & w & As & $\mathrm{Ca}$ & U \\
\hline$\%$ St Dev & $*$ & 44.01 & * & $*$ & 6.56 & 5.29 & 4.22 & $*$ & 1.35 & $*$ & 6.63 & * & & 5.95 \\
\hline HLDS_S_CB_2_B rep.1 & $<5$ & 12.04 & $<5$ & $<5$ & 26.07 & 5758.00 & 164.80 & $<5$ & 14.24 & $<5$ & 3566.00 & $<5$ & NS & 648.00 \\
\hline HLDS_S_CB_2_B rep. 2 & $<5$ & 5.00 & $<5$ & $<5$ & 25.91 & 6229.00 & 172.20 & $<5$ & 15.12 & $<5$ & 1216.00 & $<5$ & NS & 608.00 \\
\hline HLDS_S_CB_2_B rep. 3 & $<5$ & 5.00 & $<5$ & $<5$ & 23.94 & 5652.00 & 161.90 & $<5$ & 14.12 & $<5$ & 1378.00 & $<5$ & NS & 612.90 \\
\hline Average & $<5$ & 7.35 & $<5$ & $<5$ & 25.31 & 5879.67 & 166.30 & $<5$ & 14.49 & $<5$ & 2053.33 & $<5$ & & 622.97 \\
\hline St dev & * & 4.06 & * & * & 1.19 & 307.14 & 5.31 & * & 0.55 & * & 1312.51 & * & & 21.82 \\
\hline$\%$ St Dev & $*$ & 55.33 & * & $*$ & 4.69 & 5.22 & 3.19 & * & 3.77 & * & 63.92 & * & & 3.50 \\
\hline HLDS_B_CB_2_C rep. 1 & 50.18 & 36.35 & 63.34 & 5.00 & 14.32 & 3964.00 & 175.00 & $<5$ & 65.14 & $<5$ & 73.63 & $<5$ & NS & 31940.00 \\
\hline HLDS_B_CB_2_C rep. 2 & 46.09 & 32.52 & 61.81 & 5.00 & 16.45 & 4520.00 & 186.80 & $<5$ & 62.75 & $<5$ & 77.15 & $<5$ & NS & 29800.00 \\
\hline HLDS_B_CB_2_C rep. 3 & 50.48 & 41.65 & 65.81 & 20.13 & 17.44 & 4231.00 & 174.10 & $<5$ & 66.24 & $<5$ & 99.99 & $<5$ & NS & 32960.00 \\
\hline Average & 48.92 & 36.84 & 63.65 & 10.04 & 16.07 & 4238.33 & 178.63 & $<5$ & 64.71 & $<5$ & 83.59 & $<5$ & & 31566.67 \\
\hline St dev & 2.45 & 4.58 & 2.02 & 8.74 & 1.59 & 278.07 & 7.09 & * & 1.78 & * & 14.31 & * & & 1612.74 \\
\hline \% St Dev & 5.01 & 12.44 & 3.17 & 86.98 & 9.92 & 6.56 & 3.97 & * & 2.76 & * & 17.12 & * & & 5.11 \\
\hline HLDS_F_CB_2_C rep. 1 & ND & ND & ND & ND & 19.78 & 4960.00 & 131.20 & ND & 13.01 & ND & 681.00 & ND & NS & 840.20 \\
\hline HLDS_F_CB_2_C rep. 2 & ND & ND & ND & ND & 21.09 & 5285.00 & 140.60 & ND & 14.53 & ND & 618.90 & ND & NS & 925.00 \\
\hline HLDS_F_CB_2_C rep. 3 & ND & ND & ND & ND & 22.17 & 5720.00 & 145.50 & ND & 15.32 & ND & 482.60 & ND & NS & 882.80 \\
\hline Average & & & & & 21.01 & 5321.67 & 139.10 & & 14.29 & & 594.17 & & & 882.67 \\
\hline St dev & & & & & 1.20 & 381.32 & 7.27 & & 1.17 & & 101.49 & & & 42.40 \\
\hline$\%$ St Dev & & & & & 5.70 & 7.17 & 5.22 & & 8.22 & & 17.08 & & & 4.80 \\
\hline HLDS_S_CB_2_C rep. 1 & ND & 10.29 & 17.51 & ND & 22.24 & 4593.00 & 135.20 & ND & 10.97 & ND & 3434.00 & ND & NS & 431.70 \\
\hline HLDS_S_CB_2_C rep. 2 & ND & 11.51 & 10.54 & ND & 32.67 & 4614.00 & 134.20 & ND & 11.14 & ND & 4142.00 & ND & NS & 412.80 \\
\hline HLDS_S_CB_2_C rep. 3 & ND & 10.69 & ND & ND & 22.74 & 4492.00 & 135.10 & ND & 11.24 & ND & 3679.00 & ND & NS & 452.20 \\
\hline Average & & 10.83 & 14.03 & & 25.88 & 4566.33 & 134.83 & & 11.12 & & 3751.67 & & & 432.23 \\
\hline St dev & & 0.62 & 4.93 & & 5.88 & 65.23 & 0.55 & & 0.14 & & 359.55 & & & 19.71 \\
\hline \% St Dev & & 5.74 & 35.14 & & 22.73 & 1.43 & 0.41 & & 1.23 & & 9.58 & & & 4.56 \\
\hline
\end{tabular}


Table D8. Catch Box 3 HLDS

\begin{tabular}{|c|c|c|c|c|c|c|c|c|c|c|c|c|c|c|}
\hline \multirow[t]{2}{*}{ Separation Procedure } & \multicolumn{14}{|c|}{ Metals (mg/kg) } \\
\hline & $\mathrm{Pb}$ & $\mathrm{Cr}$ & $\mathrm{Cu}$ & $\mathrm{Ni}$ & $\mathrm{Zn}$ & $\mathrm{Fe}$ & $\mathrm{Mn}$ & Mo & $\mathrm{V}$ & $\mathrm{Sb}$ & W & As & $\mathrm{Ca}$ & $\mathrm{U}$ \\
\hline HLDS_B_CB_3_A rep. 1 & 22.41 & 28.89 & 41.86 & 18.77 & 69.98 & 18580.00 & 507.00 & $<5$ & 71.17 & $<5$ & 93.34 & $<5$ & NS & 11990.00 \\
\hline HLDS_B_CB_3_A rep. 2 & 21.19 & 27.85 & 37.35 & 17.21 & 63.46 & 17230.00 & 485.50 & $<5$ & 67.04 & $<5$ & 150.10 & $<5$ & NS & 12140.00 \\
\hline HLDS_B_CB_3_A rep. 3 & 20.38 & 30.27 & 38.47 & 18.25 & 69.56 & 19030.00 & 515.80 & $<5$ & 73.72 & $<5$ & 92.76 & $<5$ & NS & 12040.00 \\
\hline Average & 21.33 & 29.00 & 39.23 & 18.08 & 67.67 & 18280.00 & 502.77 & $<5$ & 70.64 & $<5$ & 112.07 & * & & 12056.67 \\
\hline St dev & 1.02 & 1.21 & 2.35 & 0.79 & 3.65 & 936.75 & 15.59 & * & 3.37 & * & 32.94 & * & & 76.38 \\
\hline$\%$ St Dev & 4.79 & 4.19 & 5.99 & 4.39 & 5.39 & 5.12 & 3.10 & * & 4.77 & * & 29.39 & * & & 0.63 \\
\hline HLDS_F_CB_3_A rep.1 & $<5$ & 13.86 & 13.19 & 10.76 & 40.41 & 9939.00 & 248.20 & $<5$ & 23.11 & $<5$ & 1823.00 & $<5$ & NS & 195.60 \\
\hline HLDS_F_CB_3_A rep. 2 & $<5$ & 14.02 & 13.63 & 12.04 & 42.25 & 10160.00 & 253.60 & $<5$ & 23.05 & $<5$ & 1959.00 & $<5$ & NS & 204.40 \\
\hline HLDS_F_CB_3_A rep. 3 & $<5$ & 13.68 & 13.03 & 11.02 & 40.12 & 9862.00 & 248.50 & $<5$ & 22.69 & $<5$ & 1750.00 & $<5$ & NS & 196.20 \\
\hline Average & $<5$ & 13.85 & 13.28 & 11.27 & 40.93 & 9987.00 & 250.10 & $<5$ & 22.95 & $<5$ & 1844.00 & * & & 198.73 \\
\hline St dev & * & 0.17 & 0.31 & 0.68 & 1.16 & 154.69 & 3.03 & * & 0.23 & * & 106.07 & * & & 4.92 \\
\hline$\%$ St Dev & * & 1.23 & 2.34 & 6.00 & 2.82 & 1.55 & 1.21 & * & 0.99 & * & 5.75 & * & & 2.47 \\
\hline HLDS_S_CB_3_A rep.1 & $<5$ & $<5$ & $<5$ & $<5$ & 15.77 & 3895.00 & 91.14 & $<5$ & $<5$ & $<5$ & 567.80 & $<5$ & NS & 161.90 \\
\hline HLDS_S_CB_3_A rep. 2 & $<5$ & $<5$ & $<5$ & $<5$ & 15.30 & 4043.00 & 93.23 & $<5$ & $<5$ & $<5$ & 512.00 & $<5$ & NS & 147.20 \\
\hline HLDS_S_CB_3_A rep. 3 & $<5$ & $<5$ & $<5$ & $<5$ & 14.81 & 4024.00 & 93.43 & $<5$ & $<5$ & $<5$ & 636.10 & $<5$ & NS & 145.00 \\
\hline Average & $<5$ & $<5$ & $<5$ & $<5$ & 15.29 & 3987.33 & 92.60 & $<5$ & $<5$ & $<5$ & 571.97 & $<5$ & & 151.37 \\
\hline St dev & * & * & * & $*$ & 0.48 & 80.53 & 1.27 & * & * & * & 62.15 & * & & 9.19 \\
\hline$\%$ St Dev & * & * & * & * & 3.14 & 2.02 & 1.37 & * & * & * & 10.87 & * & & 6.07 \\
\hline HLDS_B_CB_3_B rep.1 & 56.88 & 50.41 & 81.06 & 19.20 & 61.49 & 15870.00 & 441.00 & $<5$ & 99.28 & $<5$ & 159.20 & $<5$ & NS & 39610.00 \\
\hline HLDS_B_CB_3_B rep. 2 & 59.77 & 50.67 & 83.17 & 19.60 & 63.44 & 16440.00 & 451.80 & $<5$ & 101.40 & $<5$ & 166.80 & $<5$ & NS & 40210.00 \\
\hline HLDS_B_CB_3_B rep. 3 & 60.14 & 50.15 & 80.48 & 20.25 & 63.98 & 16520.00 & 456.50 & $<5$ & 100.50 & $<5$ & 152.80 & $<5$ & NS & 39260.00 \\
\hline Average & 58.93 & 50.41 & 81.57 & 19.68 & 62.97 & 16276.67 & 449.77 & $<5$ & 100.39 & $<5$ & 159.60 & $<5$ & & 39693.33 \\
\hline St dev & 1.78 & 0.26 & 1.42 & 0.53 & 1.31 & 354.45 & 7.95 & * & 1.06 & * & 7.01 & * & & 480.45 \\
\hline$\%$ St Dev & 3.03 & 0.52 & 1.74 & 2.69 & 2.08 & 2.18 & 1.77 & * & 1.06 & * & 4.39 & * & & 1.21 \\
\hline HLDS_F_CB_3_B rep. 1 & $<5$ & $<5$ & $<5$ & $<5$ & 14.34 & 3626.00 & 98.74 & $<5$ & $<5$ & $<5$ & 507.00 & $<5$ & NS & 453.20 \\
\hline HLDS_F_CB_3_B rep. 2 & $<5$ & $<5$ & $<5$ & $<5$ & 15.23 & 3855.00 & 102.50 & $<5$ & 10.66 & $<5$ & 656.10 & $<5$ & NS & 448.00 \\
\hline HLDS_F_CB_3_B rep. 3 & $<5$ & $<5$ & $<5$ & $<5$ & 15.93 & 3956.00 & 103.60 & $<5$ & 10.88 & $<5$ & 494.40 & $<5$ & NS & 421.20 \\
\hline Average & $<5$ & $<5$ & $<5$ & $<5$ & 15.17 & 3812.33 & 101.61 & $<5$ & 10.77 & $<5$ & 552.50 & $<5$ & & 440.80 \\
\hline St dev & * & * & * & * & 0.80 & 169.09 & 2.55 & * & 0.16 & * & 89.94 & * & & 17.17 \\
\hline$\%$ St Dev & * & * & * & * & 5.25 & 4.44 & 2.51 & * & 1.44 & * & 16.28 & * & & 3.90 \\
\hline
\end{tabular}




\begin{tabular}{|c|c|c|c|c|c|c|c|c|c|c|c|c|c|c|}
\hline \multirow[t]{2}{*}{ Separation Procedure } & \multicolumn{14}{|c|}{ Metals (mg/kg) } \\
\hline & $\mathrm{Pb}$ & $\mathrm{Cr}$ & $\mathrm{Cu}$ & $\mathrm{Ni}$ & $\mathrm{Zn}$ & $\mathrm{Fe}$ & $\mathrm{Mn}$ & Mo & $\mathrm{V}$ & $\mathrm{Sb}$ & W & As & $\mathrm{Ca}$ & $\mathrm{U}$ \\
\hline HLDS_S_CB_3_B rep. 1 & $<5$ & 15.36 & 17.09 & 13.85 & 51.48 & 12120.00 & 310.50 & $<5$ & 29.72 & $<5$ & 1097.00 & $<5$ & NS & 512.90 \\
\hline HLDS_S_CB_3_B rep. 2 & $<5$ & 16.25 & 18.11 & 14.71 & 53.97 & 12770.00 & 321.60 & $<5$ & 32.00 & $<5$ & 943.50 & $<5$ & NS & 474.40 \\
\hline HLDS_S_CB_3_B rep.3 & $<5$ & 16.08 & 17.68 & 14.51 & 52.46 & 12710.00 & 322.40 & $<5$ & 30.68 & $<5$ & 1093.00 & $<5$ & NS & 474.80 \\
\hline Average & $<5$ & 15.90 & 17.63 & 14.36 & 52.64 & 12533.33 & 318.17 & $<5$ & 30.80 & $<5$ & 1044.50 & $<5$ & & 487.37 \\
\hline St dev & * & 0.47 & 0.51 & 0.45 & 1.25 & 359.21 & 6.65 & * & 1.14 & * & 87.49 & * & & 22.11 \\
\hline$\%$ St Dev & * & 2.97 & 2.91 & 3.13 & 2.38 & 2.87 & 2.09 & * & 3.72 & * & 8.38 & * & & 4.54 \\
\hline HLDS_B_CB_3_C rep. 1 & 15.37 & 22.23 & 27.55 & 13.42 & 48.18 & 15520.00 & 400.70 & $<5$ & 61.54 & $<5$ & 180.40 & $<5$ & NS & 8131.00 \\
\hline HLDS_B_CB_3_C rep. 2 & 15.40 & 20.73 & 28.25 & 12.38 & 42.36 & 13280.00 & 385.60 & $<5$ & 51.65 & $<5$ & 263.40 & $<5$ & NS & 8987.00 \\
\hline HLDS_B_CB_3_C rep. 3 & 17.59 & 18.73 & 27.26 & 11.30 & 38.37 & 11830.00 & 354.80 & $<5$ & 47.97 & $<5$ & 291.00 & $<5$ & NS & 8902.00 \\
\hline Average & 16.12 & 20.56 & 27.69 & 12.37 & 42.97 & 13543.33 & 380.37 & $<5$ & 53.72 & $<5$ & 244.93 & $<5$ & & 8673.33 \\
\hline St dev & 1.27 & 1.76 & 0.51 & 1.06 & 4.93 & 1859.04 & 23.39 & * & 7.02 & * & 57.57 & * & & 471.59 \\
\hline$\%$ St Dev & 7.90 & 8.54 & 1.84 & 8.57 & 11.48 & 13.73 & 6.15 & * & 13.06 & * & 23.50 & * & & 5.44 \\
\hline HLDS_F_CB_3_C rep.1 & $<5$ & $<5$ & $<5$ & $<5$ & 14.37 & 3694.00 & 97.63 & $<5$ & 5.00 & $<5$ & 560.40 & $<5$ & NS & 196.00 \\
\hline HLDS_F_CB_3_C rep. 2 & $<5$ & $<5$ & $<5$ & $<5$ & 17.94 & 4237.00 & 106.40 & $<5$ & 10.84 & $<5$ & 513.00 & $<5$ & NS & 178.10 \\
\hline HLDS_F_CB_3_C rep. 3 & $<5$ & $<5$ & $<5$ & $<5$ & 15.20 & 3921.00 & 100.90 & $<5$ & 5.00 & $<5$ & 518.40 & $<5$ & NS & 182.80 \\
\hline Average & $<5$ & $<5$ & $<5$ & $<5$ & 15.84 & 3950.67 & 101.64 & $<5$ & 6.95 & $<5$ & 530.60 & $<5$ & & 185.63 \\
\hline St dev & * & * & * & * & 1.87 & 272.71 & 4.43 & * & 3.37 & * & 25.95 & * & & 9.28 \\
\hline$\%$ St Dev & * & * & * & * & 11.80 & 6.90 & 4.36 & * & 48.54 & * & 4.89 & * & & 5.00 \\
\hline HLDS_S_CB_3_C rep. 1 & $<5$ & 12.49 & 11.97 & 10.87 & 43.91 & 10650.00 & 295.00 & $<5$ & 25.22 & $<5$ & 1177.00 & $<5$ & NS & 225.30 \\
\hline HLDS_S_CB_3_C rep. 2 & $<5$ & 13.62 & 13.01 & 11.74 & 48.18 & 11520.00 & 311.90 & $<5$ & 28.21 & $<5$ & 1483.00 & $<5$ & NS & 205.00 \\
\hline HLDS_S_CB_3_C rep. 3 & $<5$ & 12.80 & 12.33 & 11.59 & 45.75 & 11100.00 & 302.80 & $<5$ & 26.80 & $<5$ & 1275.00 & $<5$ & NS & 210.20 \\
\hline Average & $<5$ & 12.97 & 12.44 & 11.40 & 45.95 & 11090.00 & 303.23 & $<5$ & 26.74 & $<5$ & 1311.67 & $<5$ & & 213.50 \\
\hline St dev & * & 0.58 & 0.53 & 0.47 & 2.14 & 435.09 & 8.46 & * & 1.50 & * & 156.26 & $*$ & & 10.54 \\
\hline$\%$ St Dev & * & 4.50 & 4.25 & 4.08 & 4.66 & 3.92 & 2.79 & * & 5.59 & * & 11.91 & * & & 4.94 \\
\hline HDLS-F-CB3-\#1-1 & $<5$ & $<5$ & $<5$ & $<5$ & 14.34 & 3626.00 & 98.74 & $<5$ & $<5$ & $<5$ & 507.00 & $<5$ & NS & 453.20 \\
\hline HDLS-F-CB3-\#1-2 & $<5$ & $<5$ & $<5$ & $<5$ & 15.23 & 3855.00 & 102.50 & $<5$ & 10.66 & $<5$ & 656.10 & $<5$ & NS & 448.00 \\
\hline HDLS-F-CB3-\#1-3 & $<5$ & $<5$ & $<5$ & $<5$ & 15.93 & 3956.00 & 103.60 & $<5$ & 10.88 & $<5$ & 494.40 & $<5$ & NS & 421.20 \\
\hline Average & $<5$ & $<5$ & $<5$ & $<5$ & 15.17 & 3812.33 & 101.61 & $<5$ & 10.77 & $<5$ & 552.50 & $<5$ & & 440.80 \\
\hline St dev & * & * & * & * & 0.80 & 169.09 & 2.55 & * & 0.16 & * & 89.94 & * & & 17.17 \\
\hline \% St Dev & * & * & * & * & 5.25 & 4.44 & 2.51 & * & 1.44 & * & 16.28 & * & & 3.90 \\
\hline HDLS-F-CB3-\#2-1 & $<5$ & $<5$ & $<5$ & $<5$ & 14.37 & 3694.00 & 97.63 & $<5$ & 5.00 & $<5$ & 560.40 & $<5$ & NS & 196.00 \\
\hline HDLS-F-CB3-\#2-2 & $<5$ & $<5$ & $<5$ & $<5$ & 17.94 & 4237.00 & 106.40 & $<5$ & 10.84 & $<5$ & 513.00 & $<5$ & NS & 178.10 \\
\hline
\end{tabular}




\begin{tabular}{|c|c|c|c|c|c|c|c|c|c|c|c|c|c|c|}
\hline \multirow[t]{2}{*}{ Separation Procedure } & \multicolumn{14}{|c|}{ Metals (mg/kg) } \\
\hline & $\mathrm{Pb}$ & $\mathrm{Cr}$ & $\mathrm{Cu}$ & $\mathrm{Ni}$ & $\mathrm{Zn}$ & $\mathrm{Fe}$ & $\mathrm{Mn}$ & Mo & $\mathrm{v}$ & $\mathrm{Sb}$ & w & As & $\mathrm{Ca}$ & $U$ \\
\hline HDLS-F-CB3-\#2-3 & $<5$ & $<5$ & $<5$ & $<5$ & 15.20 & 3921.00 & 100.90 & $<5$ & 5.00 & $<5$ & 518.40 & $<5$ & NS & 182.80 \\
\hline St dev & * & * & * & * & 1.87 & 272.71 & 4.43 & * & 3.37 & * & 25.95 & * & & 9.28 \\
\hline$\%$ St Dev & * & * & * & * & 11.80 & 6.90 & 4.36 & * & 48.54 & * & 4.89 & * & & 5.00 \\
\hline
\end{tabular}


Table D9. DU Garden 1 HLDS

\begin{tabular}{|c|c|c|c|c|c|c|c|c|c|c|c|c|c|c|}
\hline \multirow[t]{2}{*}{ Separation Procedure } & \multicolumn{14}{|c|}{ Metals (mg/kg) } \\
\hline & $\mathrm{Pb}$ & $\mathrm{Cr}$ & $\mathrm{Cu}$ & $\mathrm{Ni}$ & $\mathrm{Zn}$ & $\mathrm{Fe}$ & $\mathrm{Mn}$ & Mo & $\mathrm{V}$ & $\mathrm{Sb}$ & W & As & $\mathrm{Ca}$ & $\mathrm{U}$ \\
\hline HLDS_B_DG_1 rep. 1 & $<5$ & $<5$ & $<5$ & $<5$ & $<5$ & 4274.00 & 197.10 & $<5$ & $<5$ & $<5$ & 34.47 & $<5$ & NS & $<5$ \\
\hline HLDS_B_DG_1 rep. 2 & NS & NS & NS & NS & NS & NS & NS & NS & NS & NS & NS & NS & NS & NS \\
\hline HLDS_B_DG_1 rep. 3 & NS & NS & NS & NS & NS & NS & NS & NS & NS & NS & NS & NS & NS & NS \\
\hline Average & $<5$ & $<5$ & $<5$ & $<5$ & $<5$ & 4274.00 & 197.10 & $<5$ & $<5$ & $<5$ & 34.47 & $<5$ & & $<5$ \\
\hline St dev & * & * & * & * & * & & & * & * & * & & * & & * \\
\hline \% St Dev & * & * & * & * & * & & & * & * & * & & * & & * \\
\hline HLDS_F_DG_1 rep. 1 & $<5$ & 12.27 & $<5$ & $<5$ & 20.84 & 4100.00 & 178.80 & $<5$ & $<5$ & $<5$ & 3790.00 & $<5$ & NS & $<5$ \\
\hline HLDS_F_DG_1 rep. 2 & $<5$ & 12.13 & $<5$ & $<5$ & 20.26 & 4311.00 & 175.60 & $<5$ & $<5$ & $<5$ & 3543.00 & $<5$ & NS & $<5$ \\
\hline HLDS_F_DG_1 rep. 3 & $<5$ & 10.89 & $<5$ & $<5$ & 19.38 & 3943.00 & 173.10 & $<5$ & $<5$ & $<5$ & 3139.00 & $<5$ & NS & $<5$ \\
\hline Average & $<5$ & 11.76 & $<5$ & $<5$ & 20.16 & 4118.00 & 175.83 & $<5$ & $<5$ & $<5$ & 3490.67 & $<5$ & & $<5$ \\
\hline St dev & * & 0.76 & * & * & 0.74 & 184.66 & 2.86 & * & * & * & 328.64 & * & & * \\
\hline$\%$ St Dev & $*$ & 6.46 & * & * & 3.65 & 4.48 & 1.62 & * & * & * & 9.41 & * & & * \\
\hline HLDS_S_DG_1 rep. 1 & $<5$ & $<5$ & $<5$ & $<5$ & 21.35 & 4393.00 & 182.60 & $<5$ & $<5$ & $<5$ & 2295.00 & $<5$ & NS & $<5$ \\
\hline HLDS_S_DG_1 rep. 2 & $<5$ & $<5$ & $<5$ & $<5$ & 17.77 & 3405.00 & 163.30 & $<5$ & $<5$ & $<5$ & 2936.00 & $<5$ & NS & $<5$ \\
\hline HLDS_S_DG_1 rep. 3 & $<5$ & $<5$ & $<5$ & $<5$ & 19.30 & 3393.00 & 166.70 & $<5$ & $<5$ & $<5$ & 2786.00 & $<5$ & NS & $<5$ \\
\hline Average & $<5$ & $<5$ & $<5$ & $<5$ & 19.47 & 3730.33 & 170.87 & $<5$ & $<5$ & $<5$ & 2672.33 & $<5$ & & $<5$ \\
\hline St dev & * & * & * & * & 1.80 & 573.92 & 10.30 & * & * & * & 335.28 & * & & * \\
\hline \% St Dev & $*$ & * & * & * & 9.22 & 15.39 & 6.03 & * & * & * & 12.55 & * & & * \\
\hline
\end{tabular}


Table D10. DU Garden 2 HLDS

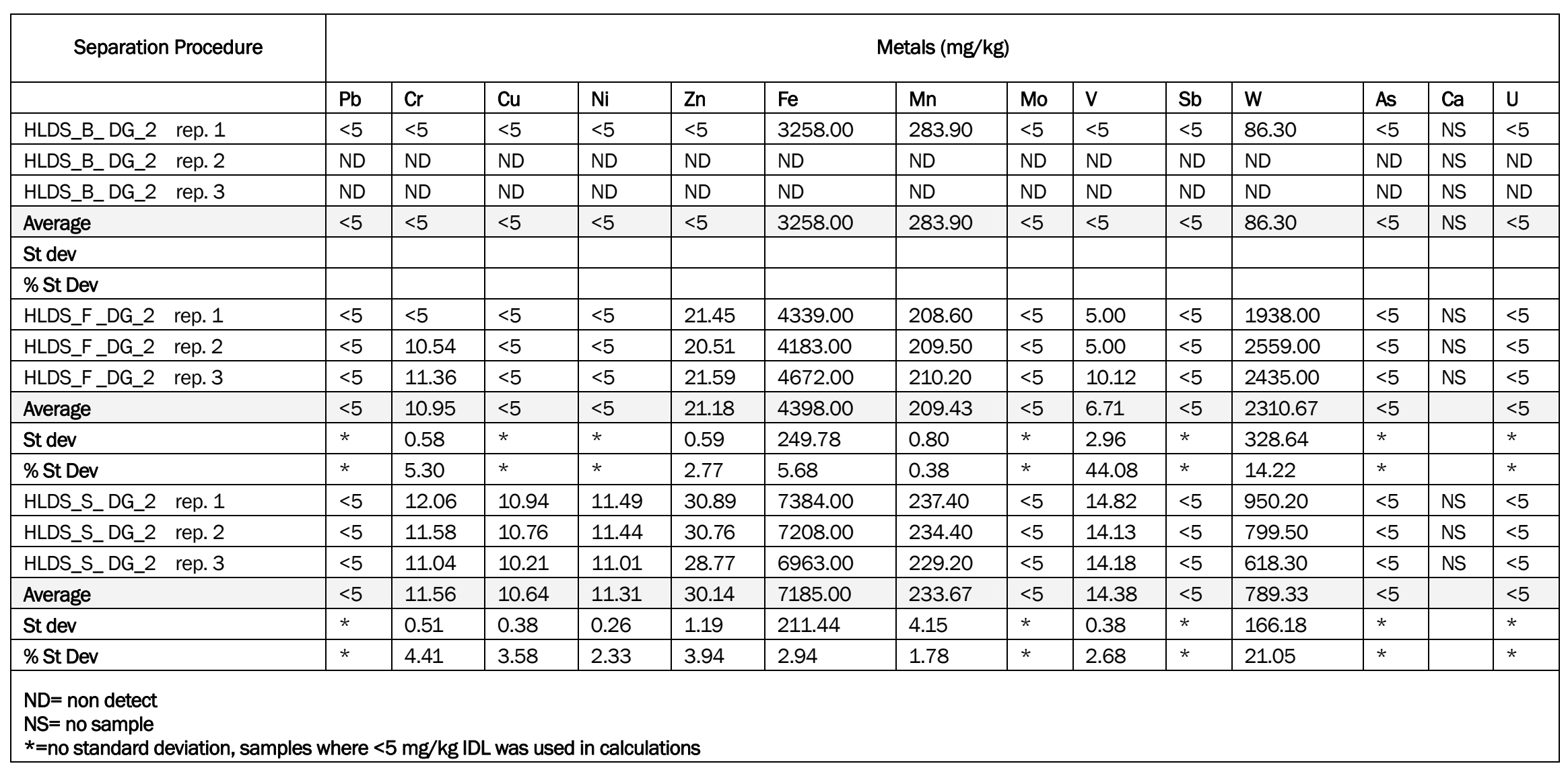


Table D11. DU Garden 3 HLDS

\begin{tabular}{|c|c|c|c|c|c|c|c|c|c|c|c|c|c|c|}
\hline \multirow[t]{2}{*}{ Separation Procedure } & \multicolumn{14}{|c|}{ Metals (mg/kg) } \\
\hline & $\mathrm{Pb}$ & $\mathrm{Cr}$ & $\mathrm{Cu}$ & $\mathrm{Ni}$ & $\mathrm{Zn}$ & $\mathrm{Fe}$ & $\mathrm{Mn}$ & Mo & $\mathrm{V}$ & $\mathrm{Sb}$ & W & As & $\mathrm{Ca}$ & U \\
\hline HLDS_B_DG_3 rep.1 & $<5$ & $<5$ & $<5$ & $<5$ & $<5$ & 2704.00 & 219.80 & $<5$ & $<5$ & $<5$ & 703.00 & $<5$ & NS & 138.70 \\
\hline HLDS_B_DG_3 rep. 2 & ND & ND & ND & ND & ND & ND & ND & ND & ND & ND & ND & ND & NS & ND \\
\hline HLDS_B_DG_3 rep. 3 & ND & ND & ND & ND & ND & 0.00 & 0.00 & ND & ND & ND & 0.00 & ND & NS & 0.00 \\
\hline Average & $<5$ & $<5$ & $<5$ & $<5$ & $<5$ & 1352.00 & 109.90 & $<5$ & $<5$ & $<5$ & 351.50 & $<5$ & & 69.35 \\
\hline St dev & * & * & * & * & * & 1912.02 & 155.42 & * & * & * & 497.10 & $*$ & & 98.08 \\
\hline \% St Dev & * & * & * & * & * & 141.42 & 141.42 & * & * & * & 141.42 & * & & 141.42 \\
\hline HLDS_F_DG_3 rep.1 & $<5$ & 11.96 & $<5$ & 10.77 & 24.97 & 5301.00 & 217.10 & $<5$ & $<5$ & $<5$ & 1108.00 & $<5$ & NS & $<5$ \\
\hline HLDS_F_DG_3 rep. 2 & $<5$ & 13.54 & $<5$ & 10.52 & 23.96 & 4922.00 & 211.70 & $<5$ & $<5$ & $<5$ & 1885.00 & $<5$ & NS & $<5$ \\
\hline HLDS_F_DG_3 rep. 3 & $<5$ & 11.46 & $<5$ & 11.10 & 25.66 & 4420.00 & 205.30 & $<5$ & $<5$ & $<5$ & 1434.00 & $<5$ & NS & $<5$ \\
\hline Average & $<5$ & 12.32 & $<5$ & 10.80 & 24.86 & 4881.00 & 211.37 & $<5$ & $<5$ & $<5$ & 1475.67 & $<5$ & & $<5$ \\
\hline St dev & * & 1.09 & * & 0.29 & 0.86 & 441.93 & 5.91 & * & * & * & 390.17 & $*$ & & * \\
\hline$\%$ St Dev & * & 8.81 & * & 2.69 & 3.44 & 9.05 & 2.79 & * & * & * & 26.44 & * & & * \\
\hline HLDS_S_DG_3 rep.1 & $<5$ & 12.12 & $<5$ & 5.00 & 23.57 & 4841.00 & 210.80 & $<5$ & 5.00 & 5.00 & 1716.00 & $<5$ & NS & $<5$ \\
\hline HLDS_S_DG_3 rep. 2 & $<5$ & 11.04 & $<5$ & 5.00 & 24.40 & 4481.00 & 206.50 & $<5$ & 5.00 & 5.00 & 1421.00 & $<5$ & NS & $<5$ \\
\hline HLDS_S_DG_3 rep. 3 & ND & 13.05 & ND & 12.23 & 28.11 & 6561.00 & 221.80 & $<5$ & 10.46 & ND & 829.10 & $<5$ & NS & $<5$ \\
\hline Average & $<5$ & 12.07 & $<5$ & 7.41 & 25.36 & 5294.33 & 213.03 & $<5$ & 6.82 & 5.00 & 1322.03 & $<5$ & & $<5$ \\
\hline St dev & * & 1.01 & $*$ & 4.17 & 2.42 & 1111.64 & 7.89 & * & 3.15 & 0.00 & 451.66 & * & & * \\
\hline$\%$ St Dev & * & 8.33 & $*$ & 56.33 & 9.53 & 21.00 & 3.70 & * & 46.22 & 0.00 & 34.16 & * & & * \\
\hline
\end{tabular}


Table D12. DU Garden 4 HLDS

\begin{tabular}{|c|c|c|c|c|c|c|c|c|c|c|c|c|c|c|}
\hline Separation Procedure & \multicolumn{14}{|c|}{ Metals (mg/kg) } \\
\hline & $\mathrm{Pb}$ & $\mathrm{Cr}$ & $\mathrm{Cu}$ & $\mathrm{Ni}$ & $\mathrm{Zn}$ & $\mathrm{Fe}$ & $\mathrm{Mn}$ & Mo & $\mathrm{v}$ & $\mathrm{Sb}$ & w & As & $\mathrm{Ca}$ & $\mathrm{U}$ \\
\hline HLDS_B_DG_4 rep. 1 & 630.40 & 400.60 & 710.90 & 53.58 & $<5$ & 5670.00 & 162.20 & $<5$ & 594.70 & $<5$ & 130.20 & $<5$ & NS & NS \\
\hline HLDS_B_DG_4 rep. 3 & 637.60 & 417.30 & 737.50 & 55.14 & $<5$ & 5738.00 & 200.80 & $<5$ & 609.00 & $<5$ & 194.10 & $<5$ & NS & NS \\
\hline Average & 648.10 & 417.73 & 735.83 & 54.97 & $<5$ & 5213.00 & 171.47 & $<5$ & 615.70 & $<5$ & 161.87 & $<5$ & & \\
\hline St dev & 24.69 & 17.35 & 24.14 & 1.32 & & 851.12 & 25.97 & * & 25.03 & * & 31.95 & * & & \\
\hline HLDS_F_DG_4 rep. 2 & $<5$ & 22.64 & $<5$ & $<5$ & 28.65 & 5992.00 & 189.20 & $<5$ & 12.55 & $<5$ & 9149.00 & $<5$ & NS & 548.20 \\
\hline HLDS_F_DG_4 rep. 3 & $<5$ & 21.19 & $<5$ & $<5$ & 28.06 & 5878.00 & 187.50 & $<5$ & 11.75 & $<5$ & 7939.00 & $<5$ & NS & 550.20 \\
\hline Average & $<5$ & 20.67 & $<5$ & $<5$ & 27.70 & 5804.00 & 186.60 & $<5$ & 11.90 & $<5$ & 7965.33 & $<5$ & & 656.27 \\
\hline St dev & * & 2.28 & * & * & 1.17 & 233.95 & 3.15 & * & 0.59 & * & 1170.72 & * & & 185.45 \\
\hline \% St Dev & * & 11.01 & * & * & 4.23 & 4.03 & 1.69 & * & 4.92 & * & 14.70 & * & & 28.26 \\
\hline HLDS_S_DG_4 rep. 1 & $<5$ & 12.16 & 56.45 & 10.16 & 26.77 & 6535.00 & 192.60 & $<5$ & 13.07 & $<5$ & 1295.00 & $<5$ & NS & 554.20 \\
\hline$\%$ St Dev & * & 4.55 & 134.11 & 44.33 & 3.57 & 6.59 & 2.98 & * & 5.60 & * & 7.46 & * & & 2.81 \\
\hline
\end{tabular}


Table D13. DU Garden 5 HLDS

\begin{tabular}{|c|c|c|c|c|c|c|c|c|c|c|c|c|c|c|}
\hline \multirow[t]{2}{*}{ Separation Procedure } & \multicolumn{14}{|c|}{ Metals (mg/kg) } \\
\hline & $\mathrm{Pb}$ & $\mathrm{Cr}$ & $\mathrm{Cu}$ & $\mathrm{Ni}$ & $\mathrm{Zn}$ & $\mathrm{Fe}$ & $\mathrm{Mn}$ & Mo & V & $\mathrm{Sb}$ & W & As & $\mathrm{Ca}$ & $\mathrm{U}$ \\
\hline HLDS_B_DG_5 rep. 1 & 843.50 & 547.60 & 1114.00 & $<5$ & $<5$ & 986.10 & 115.50 & $<5$ & 952.90 & $<5$ & 363.40 & $<5$ & NS & 627600.00 \\
\hline HLDS_B_DG_5 rep. 2 & 838.10 & 544.50 & 1114.00 & $<5$ & $<5$ & 1038.00 & 115.70 & $<5$ & 950.90 & $<5$ & 299.10 & $<5$ & NS & 624200.00 \\
\hline HLDS_B_DG_5 rep. 3 & 828.30 & 540.80 & 1104.00 & $<5$ & $<5$ & 976.50 & 112.50 & $<5$ & 939.80 & $<5$ & 779.20 & $<5$ & NS & 622500.00 \\
\hline Average & 836.63 & 544.30 & 1110.67 & $<5$ & $<5$ & 1000.20 & 114.57 & $<5$ & 947.87 & $<5$ & 480.57 & $<5$ & & 624766.67 \\
\hline St dev & 7.71 & 3.40 & 5.77 & * & * & 33.09 & 1.79 & * & 7.06 & * & 260.61 & * & & 2596.79 \\
\hline \% St Dev & 0.92 & 0.63 & 0.52 & * & * & 3.31 & 1.56 & * & 0.74 & * & 54.23 & * & & 0.42 \\
\hline HLDS_F_DG_5 rep. 1 & $<5$ & 43.16 & $<5$ & $<5$ & 30.29 & 3166.00 & 138.00 & $<5$ & 10.82 & $<5$ & 12670.00 & $<5$ & NS & 2591.00 \\
\hline HLDS_F_DG_5 rep. 2 & $<5$ & 39.45 & $<5$ & $<5$ & 25.28 & 3542.00 & 144.20 & $<5$ & 11.02 & $<5$ & 11110.00 & $<5$ & NS & 2417.00 \\
\hline HLDS_F_DG_5 rep. 3 & $<5$ & 33.39 & $<5$ & $<5$ & 25.75 & 2822.00 & 130.30 & $<5$ & 5.00 & $<5$ & 9907.00 & $<5$ & NS & 2265.00 \\
\hline Average & $<5$ & 38.67 & $<5$ & $<5$ & 27.11 & 3176.67 & 137.50 & $<5$ & 8.95 & $<5$ & 11229.00 & $<5$ & & 2424.33 \\
\hline St dev & * & 4.93 & * & * & 2.77 & 360.12 & 6.96 & * & 3.42 & * & 1385.34 & * & & 163.12 \\
\hline$\%$ St Dev & * & 12.75 & * & * & 10.21 & 11.34 & 5.06 & * & 38.22 & * & 12.34 & * & & 6.73 \\
\hline HLDS_S_DG_5 rep. 1 & $<5$ & 18.71 & $<5$ & $<5$ & 25.61 & 4766.00 & 176.00 & $<5$ & 11.28 & $<5$ & 3015.00 & $<5$ & NS & 1822.00 \\
\hline HLDS_S_DG_5 rep. 2 & $<5$ & 19.54 & $<5$ & $<5$ & 26.51 & 4883.00 & 176.80 & $<5$ & 11.89 & $<5$ & 3183.00 & $<5$ & NS & 1802.00 \\
\hline HLDS_S_DG_5 rep. 3 & $<5$ & 19.81 & $<5$ & $<5$ & 27.19 & 5016.00 & 178.80 & $<5$ & 10.97 & $<5$ & 3158.00 & $<5$ & NS & 1791.00 \\
\hline Average & $<5$ & 19.35 & $<5$ & $<5$ & 26.44 & 4888.33 & 177.20 & $<5$ & 11.38 & $<5$ & 3118.67 & $<5$ & & 1805.00 \\
\hline St dev & * & 0.57 & * & * & 0.79 & 125.09 & 1.44 & * & 0.47 & * & 90.64 & * & & 15.72 \\
\hline \% St Dev & * & 2.96 & * & * & 3.00 & 2.56 & 0.81 & * & 4.11 & * & 2.91 & * & & 0.87 \\
\hline \multicolumn{15}{|c|}{$\begin{array}{l}\mathrm{ND}=\text { non detect } \\
\mathrm{NS}=\text { no sample } \\
\star=\text { no standard deviation, samples where }<5 \mathrm{mg} / \mathrm{kg} \mathrm{IDL} \text { was used in calculations } \\
\mathrm{nr}=\text { no replicate repeated }\end{array}$} \\
\hline
\end{tabular}


Table D14. Range 20-1 HLDS

\begin{tabular}{|c|c|c|c|c|c|c|c|c|c|c|c|c|c|c|}
\hline Separation Procedure & \multicolumn{14}{|c|}{ Metals (mg/kg) } \\
\hline & $\mathrm{Pb}$ & $\mathrm{Cr}$ & $\mathrm{Cu}$ & $\mathrm{Ni}$ & $\mathrm{Zn}$ & $\mathrm{Fe}$ & $\mathrm{Mn}$ & Mo & $\mathrm{V}$ & $\mathrm{Sb}$ & w & As & $\mathrm{Ca}$ & $\mathrm{U}$ \\
\hline HLDS_B_20_1_A & 284.40 & 184.10 & 470.00 & $<5$ & $<5$ & 3955.00 & 379.50 & $<5$ & 310.00 & $<5$ & 222.10 & $<5$ & 5647.00 & 183300.00 \\
\hline HLDS_B_20_1_A & 282.10 & 183.00 & 364.80 & $<5$ & $<5$ & 4896.00 & 386.50 & $<5$ & 308.60 & $<5$ & 290.70 & $<5$ & 5944.00 & 181400.00 \\
\hline HLDS_B_20_1_A & 312.10 & 205.40 & 399.30 & $<5$ & $<5$ & 6031.00 & 418.30 & $<5$ & 337.80 & $<5$ & 329.00 & $<5$ & 6297.00 & 198100.00 \\
\hline Average & 292.87 & 190.83 & 411.37 & $<5$ & $<5$ & 4960.67 & 394.77 & $<5$ & 318.80 & $<5$ & 280.60 & $<5$ & 5962.67 & 187600.00 \\
\hline St dev & 16.70 & 12.63 & 53.63 & * & * & 1039.51 & 20.68 & * & 16.47 & * & 54.16 & * & 325.40 & 9142.76 \\
\hline$\%$ St Dev & 5.70 & 6.62 & 13.04 & * & $*$ & 20.96 & 5.24 & * & 5.17 & * & 19.30 & * & 5.46 & 4.87 \\
\hline HLDS_F 20_1_A rep. 1 & $<5$ & $<5$ & $<5$ & $<5$ & $<5$ & 3835.00 & 152.90 & $<5$ & $<5$ & $<5$ & 1780.00 & $<5$ & 18050.00 & 2286.00 \\
\hline HLDS_F 20_1_A rep. 2 & $<5$ & $<5$ & $<5$ & $<5$ & $<5$ & 3952.00 & 153.30 & $<5$ & $<5$ & $<5$ & 1890.00 & $<5$ & 18140.00 & 2050.00 \\
\hline HLDS_F 20_1_A rep. 3 & $<5$ & $<5$ & $<5$ & $<5$ & $<5$ & 3411.00 & 140.80 & $<5$ & $<5$ & $<5$ & 1486.00 & $<5$ & 16660.00 & 1936.00 \\
\hline Average & $<5$ & $<5$ & $<5$ & $<5$ & $<5$ & 3732.67 & 149.00 & $<5$ & $<5$ & $<5$ & 1718.67 & $<5$ & 17616.67 & 2090.67 \\
\hline St dev & * & * & * & * & * & 284.65 & 7.10 & * & * & * & 208.87 & * & 829.72 & 178.51 \\
\hline$\%$ St Dev & * & * & * & * & $*$ & 7.63 & 4.77 & * & * & * & 12.15 & * & 4.71 & 8.54 \\
\hline HLDS_S_20_1_A & $<5$ & $<5$ & $<5$ & $<5$ & $<5$ & 4214.00 & 202.00 & $<5$ & $<5$ & $<5$ & 795.80 & $<5$ & 32370.00 & 2023.00 \\
\hline HLDS_S_20_1_A & $<5$ & $<5$ & $<5$ & $<5$ & $<5$ & 5214.00 & 231.10 & $<5$ & $<5$ & $<5$ & 1228.00 & $<5$ & 35360.00 & 2269.00 \\
\hline HLDS_S_20_1_A & $<5$ & $<5$ & $<5$ & $<5$ & $<5$ & 4746.00 & 207.80 & $<5$ & $<5$ & $<5$ & 1124.00 & $<5$ & 32250.00 & 1972.00 \\
\hline Average & $<5$ & $<5$ & $<5$ & $<5$ & $<5$ & 4724.67 & 213.63 & $<5$ & $<5$ & $<5$ & 1049.27 & $<5$ & 33326.67 & 2088.00 \\
\hline St dev & * & * & * & * & $*$ & 500.34 & 15.40 & * & * & * & 225.58 & * & 1761.94 & 158.81 \\
\hline$\%$ St Dev & * & $*$ & * & * & $*$ & 10.59 & 7.21 & * & * & * & 21.50 & * & 5.29 & 7.61 \\
\hline HLDS_B_20_1_B & 367.10 & 238.60 & 484.60 & $<5$ & $<5$ & 8216.00 & 342.60 & $<5$ & 413.80 & $<5$ & 438.40 & $<5$ & 6657.00 & 241100.00 \\
\hline HLDS_B_20_1_B & 369.20 & 239.50 & 478.10 & $<5$ & $<5$ & 8945.00 & 343.90 & $<5$ & 421.90 & $<5$ & 398.90 & $<5$ & 6763.00 & 242800.00 \\
\hline HLDS_B_20_1_B & 377.10 & 256.80 & 489.60 & $<5$ & $<5$ & 9688.00 & 352.60 & $<5$ & 428.40 & $<5$ & 352.20 & $<5$ & 7014.00 & 243400.00 \\
\hline Average & 371.13 & 244.97 & 484.10 & $<5$ & $<5$ & 8949.67 & 346.37 & $<5$ & 421.37 & $<5$ & 396.50 & $<5$ & 6811.33 & 242433.33 \\
\hline St dev & 5.27 & 10.26 & 5.77 & * & * & 736.01 & 5.44 & * & 7.31 & * & 43.15 & * & 183.34 & 1193.04 \\
\hline \% St Dev & 1.42 & 4.19 & 1.19 & * & * & 8.22 & 1.57 & * & 1.74 & * & 10.88 & * & 2.69 & 0.49 \\
\hline HLDS_F 20_1_B rep. 1 & $<5$ & $<5$ & $<5$ & $<5$ & $<5$ & 4167.00 & 170.00 & $<5$ & $<5$ & $<5$ & 675.60 & $<5$ & 26840.00 & 2765.00 \\
\hline HLDS_F 20_1_B rep. 2 & $<5$ & $<5$ & $<5$ & $<5$ & $<5$ & 4963.00 & 182.90 & $<5$ & $<5$ & $<5$ & 527.20 & $<5$ & 27310.00 & 2687.00 \\
\hline HLDS_F 20_1_B rep. 3 & $<5$ & $<5$ & $<5$ & $<5$ & $<5$ & 4429.00 & 171.00 & $<5$ & $<5$ & $<5$ & 687.60 & $<5$ & 26300.00 & 2626.00 \\
\hline Average & $<5$ & $<5$ & $<5$ & $<5$ & $<5$ & 4519.67 & 174.63 & $<5$ & $<5$ & $<5$ & 630.13 & $<5$ & 26816.67 & 2692.67 \\
\hline St dev & * & * & * & * & $*$ & 405.67 & 7.18 & * & * & * & 89.34 & * & 505.40 & 69.67 \\
\hline$\%$ St Dev & * & $*$ & * & * & * & 8.98 & 4.11 & * & * & * & 14.18 & * & 1.88 & 2.59 \\
\hline
\end{tabular}




\begin{tabular}{|c|c|c|c|c|c|c|c|c|c|c|c|c|c|c|}
\hline Separation Procedure & \multicolumn{14}{|c|}{ Metals (mg/kg) } \\
\hline & $\mathrm{Pb}$ & $\mathrm{Cr}$ & $\mathrm{Cu}$ & $\mathrm{Ni}$ & $\mathrm{Zn}$ & $\mathrm{Fe}$ & $\mathrm{Mn}$ & Mo & $\mathrm{V}$ & $\mathrm{Sb}$ & W & As & $\mathrm{Ca}$ & $\mathrm{U}$ \\
\hline HLDS_S_20_1_B rep. 1 & $<5$ & $<5$ & $<5$ & $<5$ & $<5$ & 5237.00 & 184.30 & $<5$ & $<5$ & $<5$ & 1126.00 & $<5$ & 37270.00 & 2639.00 \\
\hline HLDS_S_20_1_B rep. 2 & $<5$ & $<5$ & $<5$ & $<5$ & $<5$ & 4370.00 & 157.90 & $<5$ & $<5$ & $<5$ & 870.20 & $<5$ & 32240.00 & 2272.00 \\
\hline HLDS_S_20_1_B rep. 3 & $<5$ & $<5$ & $<5$ & $<5$ & $<5$ & 5067.00 & 169.70 & $<5$ & $<5$ & $<5$ & 656.60 & $<5$ & 32430.00 & 2303.00 \\
\hline Average & $<5$ & $<5$ & $<5$ & $<5$ & $<5$ & 4891.33 & 170.63 & $<5$ & $<5$ & $<5$ & 884.27 & $<5$ & 33980.00 & 2404.67 \\
\hline St dev & * & $*$ & $*$ & $*$ & * & 459.42 & 13.22 & * & $*$ & * & 235.02 & * & 2850.81 & 203.53 \\
\hline \% St Dev & * & * & * & * & $*$ & 9.39 & 7.75 & * & * & * & 26.58 & * & 8.39 & 8.46 \\
\hline HLDS_B_20_1_C & 216.20 & 142.10 & 283.50 & $<5$ & $<5$ & 7442.00 & 302.40 & $<5$ & 248.20 & $<5$ & 101.30 & $<5$ & 3540.00 & 140100.00 \\
\hline HLDS_B_20_1_C & 212.60 & 143.10 & 278.60 & $<5$ & $<5$ & 7252.00 & 296.50 & $<5$ & 250.80 & $<5$ & 115.70 & $<5$ & 3265.00 & 138700.00 \\
\hline HLDS_B_20_1_C & 230.50 & 143.40 & 282.70 & $<5$ & $<5$ & 7772.00 & 304.40 & $<5$ & 252.70 & $<5$ & $<5$ & $<5$ & 3306.00 & 138300.00 \\
\hline Average & 219.77 & 142.87 & 281.60 & $<5$ & $<5$ & 7488.67 & 301.10 & $<5$ & 250.57 & $<5$ & 108.50 & $<5$ & 3370.33 & 139033.33 \\
\hline St dev & 9.47 & 0.68 & 2.63 & * & * & 263.12 & 4.11 & * & 2.26 & * & 10.18 & * & 148.36 & 945.16 \\
\hline$\%$ St Dev & 4.31 & 0.48 & 0.93 & $*$ & * & 3.51 & 1.36 & * & 0.90 & * & 9.38 & * & 4.40 & 0.68 \\
\hline HLDS_F_20_1_C & $<5$ & $<5$ & $<5$ & $<5$ & $<5$ & 3644.00 & 164.20 & $<5$ & $<5$ & $<5$ & 1278.00 & $<5$ & 19640.00 & 2230.00 \\
\hline HLDS_F_20_1_C & $<5$ & $<5$ & $<5$ & $<5$ & $<5$ & 4422.00 & 178.80 & $<5$ & $<5$ & $<5$ & 1453.00 & $<5$ & 19980.00 & 2265.00 \\
\hline HLDS_F_20_1_C & $<5$ & $<5$ & $<5$ & $<5$ & $<5$ & 4292.00 & 176.10 & $<5$ & $<5$ & $<5$ & 1672.00 & $<5$ & 20530.00 & 2273.00 \\
\hline Average & $<5$ & $<5$ & $<5$ & $<5$ & $<5$ & 4119.33 & 173.03 & $<5$ & $<5$ & $<5$ & 1467.67 & $<5$ & 20050.00 & 2256.00 \\
\hline St dev & * & * & * & $*$ & * & 416.75 & 7.77 & * & * & * & 197.41 & * & 449.11 & 22.87 \\
\hline$\%$ St Dev & * & * & * & * & * & 10.12 & 4.49 & * & * & * & 13.45 & * & 2.24 & 1.01 \\
\hline HLDS_S_20_1_C rep. 1 & $<5$ & $<5$ & $<5$ & $<5$ & $<5$ & 8045.00 & 210.60 & $<5$ & $<5$ & $<5$ & 1078.00 & $<5$ & 34880.00 & 2697.00 \\
\hline HLDS_S_20_1_C rep. 2 & $<5$ & $<5$ & $<5$ & $<5$ & $<5$ & 9249.00 & 240.90 & $<5$ & $<5$ & $<5$ & 1206.00 & $<5$ & 39410.00 & 3088.00 \\
\hline HLDS_S_20_1_C rep. 3 & $<5$ & $<5$ & $<5$ & $<5$ & $<5$ & 7325.00 & 204.30 & $<5$ & $<5$ & $<5$ & 1025.00 & $<5$ & 34980.00 & 2757.00 \\
\hline Average & $<5$ & $<5$ & $<5$ & $<5$ & $<5$ & 8206.33 & 218.60 & $<5$ & $<5$ & $<5$ & 1103.00 & $<5$ & 36423.33 & 2847.33 \\
\hline St dev & * & $*$ & $*$ & $*$ & * & 972.09 & 19.57 & * & $*$ & $*$ & 93.05 & $*$ & 2587.01 & 210.57 \\
\hline \% St Dev & * & * & * & $*$ & * & 11.85 & 8.95 & * & * & $*$ & 8.44 & * & 7.10 & 7.40 \\
\hline $\begin{array}{l}\mathrm{ND}=\text { non detect } \\
\mathrm{NS}=\text { no sample } \\
*=\text { no standard deviation, sam } \\
\mathrm{nr}=\text { no replicate performed }\end{array}$ & $e<5$ & 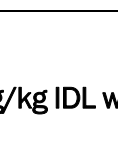 & 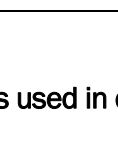 & 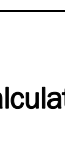 & & & & & & & & & & \\
\hline
\end{tabular}


Table D15. Range 20-2 HLDS

\begin{tabular}{|c|c|c|c|c|c|c|c|c|c|c|c|c|c|c|}
\hline Separation Procedure & \multicolumn{14}{|c|}{ Metals (mg/kg) } \\
\hline & $\mathrm{Pb}$ & $\mathrm{Cr}$ & $\mathrm{Cu}$ & $\mathrm{Ni}$ & $\mathrm{Zn}$ & $\mathrm{Fe}$ & $\mathrm{Mn}$ & Mo & $\mathrm{V}$ & $\mathrm{Sb}$ & W & As & $\mathrm{Ca}$ & $U$ \\
\hline HLDS_B_20_2 rep. 1 & 615.90 & 399.40 & 829.40 & ND & ND & 11800.00 & 513.10 & ND & 722.50 & ND & 123.80 & $\mathrm{ND}$ & & 446400.00 \\
\hline HLDS_B_2O_2 rep. 2 & NR & $\mathrm{NR}$ & NR & NR & NR & NR & NR & NR & NR & NR & NR & NR & NR & NR \\
\hline Average & 615.90 & 399.40 & 829.40 & & & 11800.00 & 513.10 & & 722.50 & & 123.80 & & & 446400.00 \\
\hline \multicolumn{15}{|l|}{ St dev } \\
\hline \multicolumn{15}{|l|}{$\%$ St Dev } \\
\hline HLDS_F_20_2 rep. 3 & $<5$ & 10.96 & 16.22 & $<5$ & 20.11 & 5210.00 & 241.60 & $<5$ & 18.66 & $<5$ & 1131.00 & $<5$ & NR & 920.70 \\
\hline Average & $<5$ & 11.40 & 16.55 & 10.51 & 20.90 & 5433.33 & 244.80 & $<5$ & 19.83 & $<5$ & 1122.00 & $<5$ & & 979.70 \\
\hline St dev & * & 0.44 & 0.47 & 0.12 & 0.89 & 202.21 & 3.06 & * & 1.08 & * & 9.00 & * & & 86.50 \\
\hline$\%$ St Dev & * & 3.82 & 2.86 & 1.14 & 4.28 & 3.72 & 1.25 & * & 5.43 & * & 0.80 & * & & 8.83 \\
\hline HLDS_S_20_2 rep.1 & 10.02 & 14.37 & 30.66 & 10.60 & 23.70 & 5741.00 & 186.40 & $<5$ & 21.09 & $<5$ & 1027.00 & $<5$ & NR & 2878.00 \\
\hline HLDS_S_20_2 rep. 2 & 10.07 & 14.07 & 29.78 & 10.00 & 21.89 & 5564.00 & 183.00 & $<5$ & 21.49 & $<5$ & 1110.00 & $<5$ & NR & 2871.00 \\
\hline
\end{tabular}


Table D16. Range 20-3 HLDS

\begin{tabular}{|c|c|c|c|c|c|c|c|c|c|c|c|c|c|c|}
\hline \multirow[t]{2}{*}{ Separation Procedure } & \multicolumn{14}{|c|}{ Metals (mg/kg) } \\
\hline & $\mathrm{Pb}$ & $\mathrm{Cr}$ & $\mathrm{Cu}$ & $\mathrm{Ni}$ & $\mathrm{Zn}$ & $\mathrm{Fe}$ & $\mathrm{Mn}$ & Mo & $\mathrm{V}$ & $\mathrm{Sb}$ & W & As & $\mathrm{Ca}$ & $\mathrm{U}$ \\
\hline HLDS_B_20_3 rep.1 & 372.60 & 178.90 & 378.40 & $<5$ & $<5$ & 6879.00 & 602.70 & $<5$ & 338.80 & $<5$ & 192.70 & $<5$ & NS & 208400.00 \\
\hline HLDS_B_20_3 rep. 2 & 351.20 & 171.90 & 355.00 & $<5$ & $<5$ & 5949.00 & 559.00 & $<5$ & 312.70 & $<5$ & 215.30 & $<5$ & NS & 192600.00 \\
\hline HLDS_B_20_3 rep. 3 & 714.50 & 426.30 & 864.10 & $<5$ & $<5$ & 4400.00 & 476.50 & $<5$ & 746.80 & $<5$ & $<5$ & $<5$ & NS & 488900.00 \\
\hline Average & 479.43 & 259.03 & 532.50 & $<5$ & $<5$ & 5742.67 & 546.07 & $<5$ & 466.10 & $<5$ & 204.00 & $<5$ & & 296633.33 \\
\hline St dev & 203.85 & 144.90 & 287.41 & * & * & 1252.31 & 64.09 & * & 243.44 & * & 15.98 & * & & 166695.12 \\
\hline$\%$ St Dev & 42.52 & 55.94 & 53.97 & * & * & 21.81 & 11.74 & * & 52.23 & * & 7.83 & * & & 56.20 \\
\hline HLDS_F_20_3 rep.1 & $<5$ & 12.37 & 18.13 & 10.79 & 23.76 & 5319.00 & 210.60 & $<5$ & 19.71 & $<5$ & 1293.00 & $<5$ & NS & 1296.00 \\
\hline HLDS_F_20_3 rep. 2 & $<5$ & 10.46 & 23.58 & 12.51 & 28.38 & 4891.00 & 190.30 & $<5$ & 17.52 & $<5$ & 767.40 & $<5$ & NS & 1152.00 \\
\hline HLDS_F_20_3 rep. 3 & $<5$ & 11.99 & 18.07 & 10.54 & 22.57 & 5312.00 & 212.40 & $<5$ & 19.16 & $<5$ & 1100.00 & $<5$ & NS & 1289.00 \\
\hline Average & $<5$ & 11.61 & 19.93 & 11.28 & 24.90 & 5174.00 & 204.43 & $<5$ & 18.80 & $<5$ & 1053.47 & $<5$ & & 1245.67 \\
\hline St dev & * & 1.01 & 3.16 & 1.07 & 3.07 & 245.11 & 12.27 & * & 1.14 & * & 265.87 & $*$ & & 81.19 \\
\hline$\%$ St Dev & * & 8.71 & 15.88 & 9.51 & 12.32 & 4.74 & 6.00 & * & 6.06 & * & 25.24 & $*$ & & 6.52 \\
\hline HLDS_S_20_3 rep.1 & $<5$ & 14.66 & 36.42 & 10.00 & 22.33 & 5372.00 & 184.30 & $<5$ & 22.40 & $<5$ & 1339.00 & $<5$ & NS & 4275.00 \\
\hline HLDS_S_20_3 rep. 2 & 10.60 & 15.49 & 36.81 & 10.70 & 23.03 & 5915.00 & 190.30 & $<5$ & 23.31 & $<5$ & 1167.00 & $<5$ & NS & 4140.00 \\
\hline HLDS_S_20_3 rep. 3 & 10.51 & 13.46 & 34.96 & $<5$ & 19.88 & 5008.00 & 176.20 & $<5$ & 21.51 & $<5$ & 816.40 & $<5$ & NS & 4231.00 \\
\hline Average & 10.56 & 14.54 & 36.06 & 10.35 & 21.75 & 5431.67 & 183.60 & $<5$ & 22.41 & $<5$ & 1107.47 & $<5$ & & 4215.33 \\
\hline St dev & 0.06 & 1.02 & 0.98 & 0.49 & 1.65 & 456.43 & 7.08 & * & 0.90 & * & 266.34 & * & & 68.85 \\
\hline \% St Dev & 0.60 & 7.02 & 2.70 & 4.78 & 7.61 & 8.40 & 3.85 & * & 4.02 & * & 24.05 & $*$ & & 1.63 \\
\hline $\begin{array}{l}\mathrm{ND}=\text { non detect } \\
\mathrm{NS}=\text { no sample } \\
*=\text { no standard deviation, sam } \\
\mathrm{nr}=\text { no replicate performed }\end{array}$ & re $<5 n$ & $\operatorname{g} \mid \mathrm{IDL}$ & sed ir & ulatio & & & & & & & & & & \\
\hline
\end{tabular}


Table D17. Summary of HLDS on Range 20 soils with soil masses, $\mathrm{mg}$ of DU per fraction and \% total DU per soil fraction

\begin{tabular}{|c|c|c|c|c|c|c|c|c|c|}
\hline \multirow[t]{2}{*}{$\begin{array}{l}\text { Density } \\
\text { Fraction }\end{array}$} & \multicolumn{3}{|c|}{ Soil Mass } & \multicolumn{3}{|c|}{ Mg of DU } & \multicolumn{3}{|c|}{$\begin{array}{c}\% \text { Total U per } \\
\text { Density Fraction* }\end{array}$} \\
\hline & $20-1 *$ & $20-2$ & $20-3$ & $20-1^{*}$ & $20-2$ & $20-3$ & $20-1$ & $20-2$ & $20-3$ \\
\hline Suspended & 0.013 & 0.012 & 0.022 & 31.81 & 34.92 & 92.74 & $2.97 \%$ & $2.41 \%$ & $8.60 \%$ \\
\hline Floating & 0.093 & 0.079 & 0.077 & 217.44 & 77.40 & 95.92 & $20.30 \%$ & $5.33 \%$ & $8.89 \%$ \\
\hline
\end{tabular}


Table D18. DU Garden 1 HLDS

\begin{tabular}{|c|c|c|c|c|c|c|c|c|c|c|c|c|c|c|}
\hline \multirow[t]{2}{*}{ Separation Procedure } & \multicolumn{14}{|c|}{ Metals (mg/kg) } \\
\hline & $\mathrm{Pb}$ & $\mathrm{Cr}$ & $\mathrm{Cu}$ & $\mathrm{Ni}$ & $\mathrm{Zn}$ & $\mathrm{Fe}$ & $\mathrm{Mn}$ & Mo & $\mathrm{V}$ & $\mathrm{Sb}$ & W & As & $\mathrm{Ca}$ & $\mathrm{U}$ \\
\hline HLDS_B_DG_1 rep. 1 & $<5$ & $<5$ & $<5$ & $<5$ & $<5$ & 4274.00 & 197.10 & $<5$ & $<5$ & $<5$ & 34.47 & $<5$ & NS & $<5$ \\
\hline HLDS_B_DG_1 rep. 2 & NS & NS & NS & NS & NS & NS & NS & NS & NS & NS & NS & NS & NS & NS \\
\hline HLDS_B_DG_1 rep. 3 & NS & NS & NS & NS & NS & NS & NS & NS & NS & NS & NS & NS & NS & NS \\
\hline Average & $<5$ & $<5$ & $<5$ & $<5$ & $<5$ & 4274.00 & 197.10 & $<5$ & $<5$ & $<5$ & 34.47 & $<5$ & & $<5$ \\
\hline St dev & * & * & * & * & * & & & * & * & * & & * & & * \\
\hline$\%$ St Dev & * & * & * & * & * & & & * & * & * & & * & & * \\
\hline HLDS_F_DG_1 rep.1 & $<5$ & 12.27 & $<5$ & $<5$ & 20.84 & 4100.00 & 178.80 & $<5$ & $<5$ & $<5$ & 3790.00 & $<5$ & NS & $<5$ \\
\hline HLDS_F_DG_1 rep. 2 & $<5$ & 12.13 & $<5$ & $<5$ & 20.26 & 4311.00 & 175.60 & $<5$ & $<5$ & $<5$ & 3543.00 & $<5$ & NS & $<5$ \\
\hline HLDS_F_DG_1 rep. 3 & $<5$ & 10.89 & $<5$ & $<5$ & 19.38 & 3943.00 & 173.10 & $<5$ & $<5$ & $<5$ & 3139.00 & $<5$ & NS & $<5$ \\
\hline Average & $<5$ & 11.76 & $<5$ & $<5$ & 20.16 & 4118.00 & 175.83 & $<5$ & $<5$ & $<5$ & 3490.67 & $<5$ & & $<5$ \\
\hline St dev & * & 0.76 & $*$ & * & 0.74 & 184.66 & 2.86 & * & * & * & 328.64 & * & & $*$ \\
\hline \% St Dev & * & 6.46 & * & * & 3.65 & 4.48 & 1.62 & * & * & * & 9.41 & * & & * \\
\hline HLDS_S_DG_1 rep. 1 & $<5$ & $<5$ & $<5$ & $<5$ & 21.35 & 4393.00 & 182.60 & $<5$ & $<5$ & $<5$ & 2295.00 & $<5$ & NS & $<5$ \\
\hline HLDS_S_DG_1 rep. 2 & $<5$ & $<5$ & $<5$ & $<5$ & 17.77 & 3405.00 & 163.30 & $<5$ & $<5$ & $<5$ & 2936.00 & $<5$ & NS & $<5$ \\
\hline HLDS_S_DG_1 rep. 3 & $<5$ & $<5$ & $<5$ & $<5$ & 19.30 & 3393.00 & 166.70 & $<5$ & $<5$ & $<5$ & 2786.00 & $<5$ & NS & $<5$ \\
\hline Average & $<5$ & $<5$ & $<5$ & $<5$ & 19.47 & 3730.33 & 170.87 & $<5$ & $<5$ & $<5$ & 2672.33 & $<5$ & & $<5$ \\
\hline St dev & * & * & * & * & 1.80 & 573.92 & 10.30 & * & $*$ & * & 335.28 & $*$ & & $*$ \\
\hline$\%$ St Dev & * & * & * & * & 9.22 & 15.39 & 6.03 & * & * & * & 12.55 & * & & $*$ \\
\hline
\end{tabular}


Table D19. Retention Pond HLDS

\begin{tabular}{|c|c|c|c|c|c|c|c|c|c|c|c|c|c|c|}
\hline \multirow[t]{2}{*}{ Separation Procedure } & \multicolumn{14}{|c|}{ Metals (mg/kg) } \\
\hline & $\mathrm{Pb}$ & $\mathrm{Cr}$ & $\mathrm{Cu}$ & $\mathrm{Ni}$ & $\mathrm{Zn}$ & $\mathrm{Fe}$ & $\mathrm{Mn}$ & Mo & $\mathrm{V}$ & $\mathrm{Sb}$ & W & As & $\mathrm{Ca}$ & $\mathrm{U}$ \\
\hline HLDS_B_RP rep. 1 & NS & NS & NS & NS & NS & NS & NS & NS & NS & NS & NS & NS & NS & NS \\
\hline HLDS_B_RP rep. 2 & NS & NS & NS & NS & NS & NS & NS & NS & NS & NS & NS & NS & NS & NS \\
\hline HLDS_B_RP rep. 3 & NS & NS & NS & NS & NS & NS & NS & NS & NS & NS & NS & NS & NS & NS \\
\hline \multicolumn{15}{|l|}{ Average } \\
\hline \multicolumn{15}{|l|}{ St dev } \\
\hline \multicolumn{15}{|l|}{$\%$ St Dev } \\
\hline HLDS_F_RP rep. 1 & $<5$ & 108.80 & 29.32 & $<5$ & 92.15 & 12090.00 & 385.40 & $<5$ & 29.33 & $<5$ & 52210.00 & $<5$ & NS & 274.80 \\
\hline HLDS_F_RP rep. 2 & $<5$ & 105.00 & 29.39 & 10.25 & 90.82 & 12520.00 & 393.30 & $<5$ & 28.06 & $<5$ & 49950.00 & $<5$ & NS & 286.30 \\
\hline HLDS_F_RP rep. 3 & $<5$ & 104.60 & 29.18 & 5.00 & 90.01 & 12070.00 & 381.90 & $<5$ & 28.52 & $<5$ & 49670.00 & $<5$ & NS & 269.20 \\
\hline Average & $<5$ & 106.13 & 29.30 & 7.63 & 90.99 & 12226.67 & 386.87 & $<5$ & 28.64 & $<5$ & 50610.00 & $<5$ & & 276.77 \\
\hline St dev & & 2.32 & 0.11 & 3.71 & 1.08 & 254.23 & 5.84 & * & 0.64 & $*$ & 1392.70 & * & & 8.72 \\
\hline \% St Dev & & 2.18 & 0.36 & 48.69 & 1.19 & 2.08 & 1.51 & * & 2.25 & * & 2.75 & * & & 3.15 \\
\hline HLDS_S_RP rep. 1 & 18.94 & 49.87 & 34.93 & 19.19 & 86.14 & 15910.00 & 477.70 & $<5$ & 34.58 & $<5$ & 16740.00 & $<5$ & NS & 278.10 \\
\hline HLDS_S_RP rep. 2 & 5.00 & 41.95 & 34.41 & 22.81 & 80.33 & 15240.00 & 453.00 & $<5$ & 33.59 & $<5$ & 12650.00 & $<5$ & NS & 239.80 \\
\hline HLDS_S_RP rep. 3 & 5.00 & 41.91 & 32.82 & 17.90 & 78.97 & 14920.00 & 440.20 & $<5$ & 32.79 & $<5$ & 12830.00 & $<5$ & NS & 232.10 \\
\hline Average & 9.65 & 44.58 & 34.05 & 19.97 & 81.81 & 15356.67 & 456.97 & $<5$ & 33.65 & $<5$ & 14073.33 & $<5$ & NS & 250.00 \\
\hline St dev & 8.05 & 4.58 & 1.10 & 2.55 & 3.81 & 505.21 & 19.06 & * & 0.90 & * & 2311.15 & * & & 24.64 \\
\hline$\%$ St Dev & 83.43 & 10.28 & 3.23 & 12.75 & 4.65 & 3.29 & 4.17 & * & 2.66 & * & 16.42 & * & & 9.86 \\
\hline
\end{tabular}




\section{Appendix E. Water/Momentum Density Separation (Wilfley Table)}


Table E1. Background 1 Separation by Wilfley Table

\begin{tabular}{|c|c|c|c|c|c|c|c|c|c|c|c|c|c|c|}
\hline Separation Procedure & & & & & & & tals (mg/ & & & & & & & \\
\hline & $\mathrm{Pb}$ & $\mathrm{Cr}$ & $\mathrm{Cu}$ & $\mathrm{Ni}$ & $\mathrm{Zn}$ & $\mathrm{Fe}$ & $\mathrm{Mn}$ & Mo & $\mathrm{V}$ & $\mathrm{Sb}$ & W & As & $\mathrm{Ca}$ & $\mathrm{U}$ \\
\hline WT_B1_BGGEL_1 rep.1 & $<5$ & $<5$ & $<5$ & $<5$ & 21.89 & 4996.00 & 180.50 & $<5$ & $<5$ & $<5$ & $<5$ & $<5$ & NS & $<5$ \\
\hline WT_B1_BGGEL_1 rep. 2 & $<5$ & $<5$ & $<5$ & $<5$ & 24.05 & 4910.00 & 179.20 & $<5$ & $<5$ & $<5$ & $<5$ & $<5$ & NS & $<5$ \\
\hline WT_B1_BGGEL_1 rep. 3 & $<5$ & $<5$ & $<5$ & $<5$ & 21.28 & 4691.00 & 177.60 & $<5$ & $<5$ & $<5$ & $<5$ & $<5$ & NS & $<5$ \\
\hline Average & $<5$ & $<5$ & $<5$ & $<5$ & 22.41 & 4865.67 & 179.10 & $<5$ & $<5$ & $<5$ & $<5$ & $<5$ & NS & $<5$ \\
\hline St dev & * & * & * & * & 1.46 & 157.26 & 1.45 & * & * & * & * & * & & * \\
\hline \% St Dev & * & * & * & * & 6.50 & 3.23 & 0.81 & * & * & * & * & * & & * \\
\hline WT_B2_BGGEL_1 rep.1 & $<5$ & $<5$ & $<5$ & $<5$ & 23.54 & 4705.00 & 186.20 & $<5$ & $<5$ & $<5$ & $<5$ & $<5$ & NS & $<5$ \\
\hline WT_B2_BGGEL_1 rep. 2 & $<5$ & $<5$ & $<5$ & $<5$ & 24.20 & 4955.00 & 189.10 & $<5$ & $<5$ & $<5$ & $<5$ & $<5$ & NS & $<5$ \\
\hline WT_B2_BGGEL_1 rep. 3 & $<5$ & $<5$ & $<5$ & $<5$ & 22.70 & 4446.00 & 184.10 & $<5$ & $<5$ & $<5$ & $<5$ & $<5$ & NS & $<5$ \\
\hline Average & $<5$ & $<5$ & $<5$ & $<5$ & 23.48 & 4702.00 & 186.47 & $<5$ & $<5$ & $<5$ & $<5$ & $<5$ & & $<5$ \\
\hline St dev & * & * & * & * & 0.75 & 254.51 & 2.51 & * & * & * & * & * & & * \\
\hline \% St Dev & * & * & * & * & 3.20 & 5.41 & 1.35 & * & * & * & * & * & & * \\
\hline WT_B3_BGGEL_1 rep.1 & $<5$ & $<5$ & $<5$ & $<5$ & 18.92 & 4367.00 & 185.80 & $<5$ & $<5$ & $<5$ & $<5$ & $<5$ & NS & $<5$ \\
\hline WT_B3_BGGEL_1 rep. 2 & $<5$ & $<5$ & $<5$ & $<5$ & 17.15 & 3878.00 & 185.40 & $<5$ & $<5$ & $<5$ & $<5$ & $<5$ & NS & $<5$ \\
\hline WT_B3_BGGEL_1 rep.3 & $<5$ & $<5$ & $<5$ & $<5$ & 18.15 & 4149.00 & 179.90 & $<5$ & $<5$ & $<5$ & $<5$ & $<5$ & NS & $<5$ \\
\hline Average & $<5$ & $<5$ & $<5$ & $<5$ & 18.07 & 4131.33 & 183.70 & $<5$ & $<5$ & $<5$ & $<5$ & $<5$ & & $<5$ \\
\hline St dev & * & * & * & * & 0.89 & 244.98 & 3.30 & * & * & * & * & * & & * \\
\hline \% St Dev & * & * & * & * & 4.91 & 5.93 & 1.79 & * & * & * & * & * & & * \\
\hline WT_B4_BGGEL_1 rep. 1 & $<5$ & $<5$ & $<5$ & $<5$ & 19.56 & 4619.00 & 196.10 & $<5$ & $<5$ & $<5$ & $<5$ & $<5$ & NS & $<5$ \\
\hline WT_B4_BGGEL_1 rep. 2 & $<5$ & $<5$ & $<5$ & $<5$ & 18.01 & 4247.00 & 193.60 & $<5$ & $<5$ & $<5$ & $<5$ & $<5$ & NS & $<5$ \\
\hline WT_B4_BGGEL_1 rep.3 & $<5$ & $<5$ & $<5$ & $<5$ & 17.52 & 3997.00 & 185.50 & $<5$ & $<5$ & $<5$ & $<5$ & $<5$ & NS & $<5$ \\
\hline Average & $<5$ & $<5$ & $<5$ & $<5$ & 18.36 & 4287.67 & 191.73 & $<5$ & $<5$ & $<5$ & $<5$ & $<5$ & & $<5$ \\
\hline St dev & * & * & * & * & 1.06 & 312.99 & 5.54 & * & * & * & * & * & & * \\
\hline \% St Dev & * & * & * & * & 5.80 & 7.30 & 2.89 & * & * & * & * & * & & * \\
\hline WT_B5_BGGEL_1 rep. 1 & $<5$ & $<5$ & $<5$ & $<5$ & 11.29 & 2803.00 & 175.50 & $<5$ & $<5$ & $<5$ & $<5$ & $<5$ & $<5$ & $<5$ \\
\hline WT_B5_BGGEL_1 rep. 2 & $<5$ & $<5$ & $<5$ & $<5$ & 12.27 & 3057.00 & 166.00 & $<5$ & $<5$ & $<5$ & $<5$ & $<5$ & $<5$ & $<5$ \\
\hline WT_B5_BGGEL_1 rep. 3 & $<5$ & $<5$ & $<5$ & $<5$ & 11.96 & 3077.00 & 174.20 & $<5$ & $<5$ & $<5$ & $<5$ & $<5$ & $<5$ & $<5$ \\
\hline Average & $<5$ & $<5$ & $<5$ & $<5$ & 11.84 & 2979.00 & 171.90 & $<5$ & $<5$ & $<5$ & $<5$ & $<5$ & & $<5$ \\
\hline St dev & * & * & * & * & 0.50 & 152.75 & 5.15 & * & * & * & * & * & & * \\
\hline \% St Dev & * & * & * & * & 4.23 & 5.13 & 3.00 & * & * & * & * & * & & * \\
\hline
\end{tabular}


Table E2. Background 2 Water Separation using the Wilfley Table

\begin{tabular}{|c|c|c|c|c|c|c|c|c|c|c|c|c|c|c|}
\hline \multirow[t]{2}{*}{ Separation Procedure } & \multicolumn{14}{|c|}{ Metals (mg/kg) } \\
\hline & $\mathrm{Pb}$ & $\mathrm{Cr}$ & $\mathrm{Cu}$ & $\mathrm{Ni}$ & $\mathrm{Zn}$ & $\mathrm{Fe}$ & $\mathrm{Mn}$ & Mo & $\mathrm{V}$ & $\mathrm{Sb}$ & W & As & $\mathrm{Ca}$ & $U$ \\
\hline WT_B1_BGGEL_2 rep.1 & 10.66 & ND & ND & ND & 22.70 & 5913.00 & 203.30 & ND & ND & ND & 25.01 & ND & NS & ND \\
\hline WT_B1_BGGEL 2 rep. 2 & 9.64 & ND & ND & ND & 18.58 & 4713.00 & 187.60 & ND & ND & ND & 29.52 & ND & NS & ND \\
\hline WT_B1_BGGEL_2 rep. 3 & 10.23 & ND & ND & ND & 20.18 & 5229.00 & 197.70 & ND & ND & ND & 31.82 & ND & NS & ND \\
\hline Average & 10.18 & ND & ND & ND & 20.49 & 5285.00 & 196.20 & ND & ND & ND & 28.78 & ND & & ND \\
\hline St dev & 0.51 & & & & 2.08 & 601.96 & 7.96 & & & & 3.46 & & & \\
\hline$\%$ St Dev & 5.05 & & & & 10.14 & 11.39 & 4.06 & & & & 12.04 & & & \\
\hline WT_B2_BGGEL_2 rep. 1 & ND & ND & ND & ND & 19.70 & 4934.00 & 183.60 & ND & ND & ND & ND & ND & NS & ND \\
\hline WT_B2_BGGEL_2 rep. 2 & ND & ND & ND & ND & 21.04 & 5375.00 & 188.80 & ND & ND & ND & ND & ND & NS & ND \\
\hline WT_B2_BGGEL_2 rep. 3 & ND & ND & ND & ND & 17.28 & 4335.00 & 175.10 & ND & ND & ND & ND & ND & NS & ND \\
\hline Average & ND & ND & ND & ND & 19.34 & 4881.33 & 182.50 & ND & ND & ND & ND & ND & & ND \\
\hline St dev & & & & & 1.91 & 522.00 & 6.92 & & & & & & & \\
\hline \% St Dev & & & & & 9.85 & 10.69 & 3.79 & & & & & & & \\
\hline WT_B3_BGGEL_2 rep. 1 & ND & ND & ND & 16.92 & 14.10 & 4193.00 & 175.00 & ND & ND & ND & ND & ND & NS & ND \\
\hline WT_B3_BGGEL_2 rep. 2 & ND & ND & ND & ND & 13.93 & 4218.00 & 179.20 & ND & ND & ND & ND & ND & NS & ND \\
\hline WT_B3_BGGEL_2 rep. 3 & ND & ND & ND & ND & 11.81 & 3581.00 & 168.00 & ND & ND & ND & ND & ND & NS & ND \\
\hline Average & ND & ND & ND & 16.92 & 13.28 & 3997.33 & 174.07 & ND & ND & ND & ND & ND & & ND \\
\hline St dev & & & & & 1.28 & 360.77 & 5.66 & & & & & & & \\
\hline$\%$ St Dev & & & & & 9.61 & 9.03 & 3.25 & & & & & & & \\
\hline WT_B4_BGGEL_2 rep. 1 & ND & ND & ND & ND & 13.37 & 4148.00 & 174.40 & ND & ND & ND & ND & ND & NS & ND \\
\hline WT_B4_BGGEL_2 rep. 2 & ND & ND & ND & ND & 14.92 & 4637.00 & 186.40 & ND & ND & ND & ND & ND & NS & ND \\
\hline WT_B4_BGGEL_2 rep. 3 & ND & ND & ND & ND & 13.33 & 4089.00 & 182.30 & ND & ND & ND & ND & ND & NS & ND \\
\hline Average & ND & ND & ND & ND & 13.87 & 4291.33 & 181.03 & ND & ND & ND & ND & ND & & ND \\
\hline St dev & & & & & 0.91 & 300.81 & 6.10 & & & & & & & \\
\hline$\%$ St Dev & & & & & 6.54 & 7.01 & 3.37 & & & & & & & \\
\hline WT_B5_BGGEL_2 rep. 1 & ND & ND & ND & ND & 13.61 & 4919.00 & 240.10 & ND & 10.88 & ND & ND & ND & NS & ND \\
\hline WT_B5_BGGEL_2 rep. 2 & ND & ND & ND & ND & 12.07 & 4360.00 & 233.90 & ND & ND & ND & ND & ND & NS & ND \\
\hline
\end{tabular}




\begin{tabular}{|c|c|c|c|c|c|c|c|c|c|c|c|c|c|c|}
\hline \multirow[t]{2}{*}{ Separation Procedure } & \multicolumn{14}{|c|}{ Metals (mg/kg) } \\
\hline & $\mathrm{Pb}$ & $\mathrm{Cr}$ & $\mathrm{Cu}$ & $\mathrm{Ni}$ & $\mathrm{Zn}$ & $\mathrm{Fe}$ & $\mathrm{Mn}$ & Mo & $\mathrm{v}$ & $\mathrm{Sb}$ & w & As & $\mathrm{Ca}$ & $U$ \\
\hline WT_B5_BGGEL_2 rep. 3 & ND & ND & ND & 10.89 & 17.66 & 6283.00 & 280.20 & ND & 12.54 & ND & ND & ND & NS & ND \\
\hline Average & ND & ND & ND & 10.89 & 14.45 & 5187.33 & 251.40 & ND & 11.71 & ND & ND & ND & & ND \\
\hline St dev & & & & & 2.89 & 989.18 & 25.13 & & 1.17 & & & & & \\
\hline$\%$ St Dev & & & & & 19.99 & 19.07 & 10.00 & & 10.02 & & & & & \\
\hline WT_B6_BGGEL_2 rep. 3 & & & & & & & & & & & & & NS & \\
\hline Average & & & & & 10.85 & 2478.00 & 121.50 & & & & & & & \\
\hline \multicolumn{15}{|l|}{ St dev } \\
\hline \multicolumn{15}{|l|}{ \% St Dev } \\
\hline WT_B7_BGGEL_2 rep. 1 & 11.16 & 12.30 & 10.32 & 12.81 & 77.34 & 55650.00 & 614.20 & ND & 18.92 & ND & ND & ND & NS & \\
\hline \multicolumn{15}{|l|}{ St dev } \\
\hline \% St Dev & & & & & & & & & & & & & & \\
\hline $\begin{array}{l}\mathrm{ND}=\text { non detect } \\
\mathrm{NS}=\text { no sample } \\
*=\text { no standard deviation, sa }\end{array}$ & vhere & 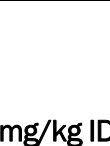 & 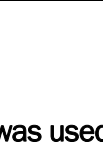 & - & & & & & & & & & & \\
\hline
\end{tabular}


Table E3. Background 3 Water Separation using the Wilfley Table

\begin{tabular}{|c|c|c|c|c|c|c|c|c|c|c|c|c|c|c|}
\hline Separation Procedure & & & & & & & (mg/kg) & & & & & & & \\
\hline (ppm) & $\mathrm{Pb}$ & $\mathrm{Cr}$ & $\mathrm{Cu}$ & $\mathrm{Ni}$ & $\mathrm{Zn}$ & $\mathrm{Fe}$ & $\mathrm{Mn}$ & Mo & V & $\mathrm{Sb}$ & W & As & $\mathrm{Ca}$ & $\mathrm{U}$ \\
\hline WT_B1_BGGEL_3 rep. 1 & ND & ND & ND & ND & 22.61 & 6269.00 & 185.50 & ND & 13.67 & ND & ND & ND & NS & ND \\
\hline WT_B1_BGGEL_3 rep. 2 & ND & ND & ND & ND & 23.10 & 6533.00 & 189.20 & ND & 14.73 & ND & ND & ND & NS & ND \\
\hline WT_B1_BGGEL_3 rep. 3 & ND & ND & ND & ND & 21.96 & 6227.00 & 184.70 & ND & 13.37 & ND & ND & ND & NS & ND \\
\hline Average & & & & & 22.56 & 6343.00 & 186.47 & & 13.92 & & & & & \\
\hline St dev & & & & & 0.57 & 165.88 & 2.40 & & 0.71 & & & & & \\
\hline$\%$ St Dev & & & & & 2.54 & 2.62 & 1.29 & & 5.13 & & & & & \\
\hline WT_B2_BGGEL_3 rep. 1 & ND & ND & ND & ND & 19.59 & 5843.00 & 178.60 & ND & 12.90 & ND & ND & ND & NS & ND \\
\hline WT_B2_BGGEL_3 rep. 2 & ND & ND & ND & ND & 19.93 & 6091.00 & 179.80 & ND & 13.53 & ND & ND & ND & NS & ND \\
\hline WT_B2_BGGEL_3 rep. 3 & ND & ND & ND & ND & 19.91 & 6088.00 & 183.20 & ND & 13.82 & ND & ND & ND & NS & ND \\
\hline Average & & & & & 19.81 & 6007.33 & 180.53 & & 13.42 & & & & & \\
\hline St dev & & & & & 0.19 & 142.32 & 2.39 & & 0.47 & & & & & \\
\hline$\%$ St Dev & & & & & 0.96 & 2.37 & 1.32 & & 3.51 & & & & & \\
\hline WT_B3_BGGEL_3 rep. 1 & ND & ND & ND & ND & 15.10 & 4936.00 & 165.10 & ND & 11.37 & ND & ND & ND & NS & ND \\
\hline WT_B3_BGGEL_3 rep. 2 & ND & ND & ND & ND & 17.40 & 5580.00 & 171.20 & ND & 12.46 & ND & ND & ND & NS & ND \\
\hline WT_B3_BGGEL_3 rep. 3 & ND & ND & ND & ND & 17.07 & 5313.00 & 171.00 & ND & 12.10 & ND & ND & ND & NS & ND \\
\hline Average & & & & & 16.52 & 5276.33 & 169.10 & & 11.98 & & & & & \\
\hline St dev & & & & & 1.24 & 323.56 & 3.47 & & 0.56 & & & & & \\
\hline$\%$ St Dev & & & & & 7.53 & 6.13 & 2.05 & & 4.64 & & & & & \\
\hline WT_B4_BGGEL_3 rep. 1 & ND & ND & ND & ND & 15.34 & 5174.00 & 177.80 & ND & 12.27 & ND & ND & ND & NS & ND \\
\hline WT_B4_BGGEL_3 rep. 2 & ND & ND & ND & ND & 17.98 & 5819.00 & 182.30 & ND & 13.66 & ND & ND & ND & NS & ND \\
\hline WT_B4_BGGEL_3 rep. 3 & ND & ND & ND & ND & 17.63 & 5993.00 & 192.10 & ND & 14.10 & ND & ND & ND & NS & ND \\
\hline Average & & & & & 16.98 & 5662.00 & 184.07 & & 13.34 & & & & & \\
\hline St dev & & & & & 1.43 & 431.48 & 7.31 & & 0.96 & & & & & \\
\hline$\%$ St Dev & & & & & 8.44 & 7.62 & 3.97 & & 7.16 & & & & & \\
\hline WT_B5_BGGEL_3 rep. 1 & ND & 12.55 & ND & 13.82 & 27.85 & 8732.00 & 271.10 & ND & 21.93 & ND & ND & ND & NS & ND \\
\hline WT_B5_BGGEL_3 rep. 2 & ND & 13.64 & ND & 14.87 & 27.32 & 9552.00 & 277.20 & ND & 23.82 & ND & ND & ND & NS & ND \\
\hline WT_B5_BGGEL_3 rep. 3 & ND & 12.72 & ND & 13.88 & 26.20 & 9072.00 & 269.90 & ND & 22.47 & ND & ND & ND & NS & ND \\
\hline Average & & 12.97 & & 14.19 & 27.12 & 9118.67 & 272.73 & & 22.74 & & & & & \\
\hline St dev & & 0.59 & & 0.59 & 0.84 & 411.99 & 3.91 & & 0.97 & & & & & \\
\hline$\%$ St Dev & & 4.52 & & 4.16 & 3.11 & 4.52 & 1.44 & & 4.28 & & & & & \\
\hline
\end{tabular}




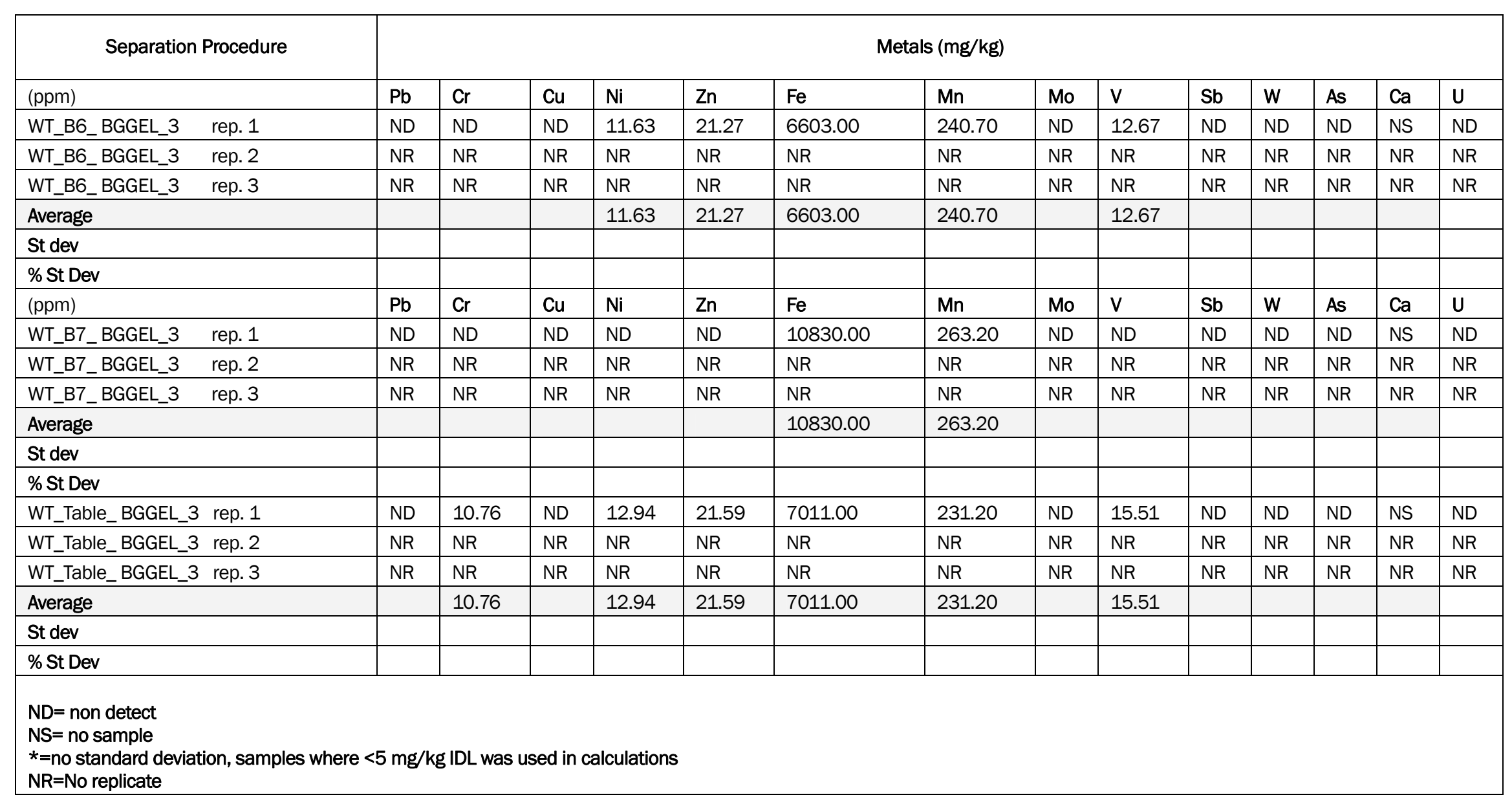


Table E4. Background 4 Water Separation using the Wilfley Table

\begin{tabular}{|c|c|c|c|c|c|c|c|c|c|c|c|c|c|c|}
\hline \multirow[t]{2}{*}{ Separation Procedure } & \multicolumn{14}{|c|}{ Metals (mg/kg) } \\
\hline & $\mathrm{Pb}$ & $\mathrm{Cr}$ & $\mathrm{Cu}$ & $\mathrm{Ni}$ & $\mathrm{Zn}$ & $\mathrm{Fe}$ & $\mathrm{Mn}$ & Mo & $\mathrm{V}$ & $\mathrm{Sb}$ & W & As & $\mathrm{Ca}$ & $\mathrm{U}$ \\
\hline WT_B1_BGGEL_4 rep. 1 & ND & 10.19 & ND & ND & 31.37 & 7458.00 & 177.40 & ND & 18.65 & ND & ND & ND & NS & ND \\
\hline WT_B1_BGGEL_4 rep. 2 & ND & 10.69 & ND & ND & 27.23 & 7746.00 & 187.10 & ND & 20.03 & ND & ND & ND & NS & ND \\
\hline WT_B1_BGGEL_4 rep. 3 & ND & 11.15 & ND & ND & 27.28 & 8152.00 & 191.20 & ND & 21.36 & ND & ND & ND & NS & ND \\
\hline Average & & 10.68 & & & 28.63 & 7785.33 & 185.23 & & 20.01 & & & & & \\
\hline St dev & & 0.48 & & & 2.38 & 348.67 & 7.09 & & 1.36 & & & & & \\
\hline$\%$ St Dev & & 4.50 & & & 8.30 & 4.48 & 3.83 & & 6.77 & & & & & \\
\hline WT_B2_BGGEL_4 rep. 1 & ND & ND & ND & ND & 25.10 & 7759.00 & 180.50 & ND & 20.37 & ND & ND & ND & NS & ND \\
\hline WT_B2_BGGEL_4 rep. 2 & ND & ND & ND & ND & 23.02 & 6666.00 & 168.30 & ND & 17.10 & ND & ND & ND & NS & ND \\
\hline WT_B2_BGGEL_4 rep. 3 & ND & ND & ND & ND & 23.30 & 6892.00 & 176.30 & ND & 17.38 & ND & ND & ND & NS & ND \\
\hline Average & & & & & 23.81 & 7105.67 & 175.03 & & 18.28 & & & & & \\
\hline St dev & & & & & 1.13 & 576.98 & 6.20 & & 1.81 & & & & & \\
\hline$\%$ St Dev & & & & & 4.74 & 8.12 & 3.54 & & 9.91 & & & & & \\
\hline WT_B3_BGGEL_4 rep. 1 & ND & 10.62 & ND & 10.52 & 24.06 & 7806.00 & 198.60 & ND & 20.36 & ND & ND & ND & NS & ND \\
\hline WT_B3_BGGEL_4 rep. 2 & ND & 10.69 & ND & 10.53 & 23.82 & 7982.00 & 198.60 & ND & 20.21 & ND & ND & ND & NS & ND \\
\hline WT_B3_BGGEL_4 rep. 3 & ND & 10.43 & ND & 10.29 & 23.59 & 7680.00 & 201.50 & ND & 19.29 & ND & ND & ND & NS & ND \\
\hline Average & & 10.58 & & 10.45 & 23.82 & 7822.67 & 199.57 & & 19.95 & & & & & \\
\hline St dev & & 0.13 & & 0.14 & 0.24 & 151.69 & 1.67 & & 0.58 & & & & & \\
\hline$\%$ St Dev & & 1.27 & & 1.30 & 0.99 & 1.94 & 0.84 & & 2.90 & & & & & \\
\hline WT_B4_BGGEL_4 rep. 1 & ND & 10.54 & ND & 10.81 & 22.78 & 7261.00 & 200.80 & ND & 18.77 & ND & 27.75 & ND & NS & ND \\
\hline WT_B4_BGGEL_4 rep. 2 & ND & 9.56 & ND & ND & 20.07 & 6354.00 & 198.90 & ND & 16.17 & ND & 31.69 & ND & NS & ND \\
\hline WT_B4_BGGEL_4 rep. 3 & ND & 9.35 & ND & ND & 20.49 & 6562.00 & 199.90 & ND & 14.37 & ND & 26.36 & ND & NS & ND \\
\hline Average & & 9.82 & & 10.81 & 21.11 & 6725.67 & 199.87 & & 16.44 & & 28.60 & & & \\
\hline St dev & & 0.63 & & & 1.46 & 475.13 & 0.95 & & 2.21 & & 2.76 & & & \\
\hline$\%$ St Dev & & 6.46 & & & 6.91 & 7.06 & 0.48 & & 13.46 & & 9.67 & & & \\
\hline WT_B5_BGGEL_4 rep. 1 & ND & 11.76 & ND & 12.29 & 21.98 & 7920.00 & 244.30 & ND & 18.89 & ND & ND & ND & NS & ND \\
\hline WT_B5_BGGEL_4 rep. 2 & ND & 12.77 & ND & 13.10 & 24.91 & 8614.00 & 243.30 & ND & 21.95 & ND & ND & ND & NS & ND \\
\hline WT_B5_BGGEL_4 rep. 3 & ND & 12.94 & ND & 13.32 & 27.73 & 9286.00 & 256.00 & ND & 23.57 & ND & ND & ND & NS & ND \\
\hline Average & & 12.49 & & 12.90 & 24.87 & 8606.67 & 247.87 & & 21.47 & & & & & \\
\hline St dev & & 0.64 & & 0.54 & 2.88 & 683.03 & 7.06 & & 2.38 & & & & & \\
\hline$\%$ St Dev & & 5.11 & & 4.20 & 11.56 & 7.94 & 2.85 & & 11.07 & & & & & \\
\hline
\end{tabular}




\begin{tabular}{|c|c|c|c|c|c|c|c|c|c|c|c|c|c|c|}
\hline Separation Procedure & $\mathrm{Pb}$ & $\mathrm{Cr}$ & $\mathrm{Cu}$ & $\mathrm{Ni}$ & $\mathrm{Zn}$ & $\mathrm{Fe}$ & $\mathrm{Mn}$ & Mo & $\mathrm{V}$ & $\mathrm{Sb}$ & w & As & $\mathrm{Ca}$ & $\mathrm{U}$ \\
\hline WT_B6_BGGEL_4 rep. 1 & ND & ND & ND & ND & ND & 8516.00 & 321.10 & ND & ND & ND & ND & ND & NS & ND \\
\hline WT_B6_BGGEL_4 rep. 3 & NR & NR & NR & NR & NR & NR & NR & NR & NR & NR & NR & NR & NR & NR \\
\hline Average & & & & & & 8516.00 & 321.10 & & & & & & & \\
\hline \multicolumn{15}{|l|}{ St dev } \\
\hline WT_Table rep. 2 & NR & NR & NR & NR & NR & NR & $\mathrm{NR}$ & NR & NR & NR & NR & NR & NR & NR \\
\hline WT_Table rep. 3 & $\mathrm{NR}$ & $\mathrm{NR}$ & NR & $\mathrm{NR}$ & NR & NR & $\mathrm{NR}$ & $\mathrm{NR}$ & NR & NR & $\mathrm{NR}$ & NR & $\mathrm{NR}$ & NR \\
\hline Average & & & & & 30.66 & 9338.00 & 280.00 & & 20.33 & & & & & \\
\hline \multicolumn{15}{|l|}{ St dev } \\
\hline \% St Dev & & & & & & & & & & & & & & \\
\hline $\begin{array}{l}N R=\text { No replicate } \\
N D=\text { non detect } \\
N S=\text { no sample } \\
\star=\text { no standard deviation, sam }\end{array}$ & & & & & & & & & & & & & & \\
\hline
\end{tabular}


Table E5. Catch Box 1 Water Separation using the Wilfley Table

\begin{tabular}{|c|c|c|c|c|c|c|c|c|c|c|c|c|c|c|}
\hline Separation Procedure & \multicolumn{14}{|c|}{ Metals (mg/kg) } \\
\hline & $\mathrm{Pb}$ & $\mathrm{Cr}$ & $\mathrm{Cu}$ & $\mathrm{Ni}$ & $\mathrm{Zn}$ & $\mathrm{Fe}$ & $\mathrm{Mn}$ & Mo & $\mathrm{V}$ & $\mathrm{Sb}$ & W & As & $\mathrm{Ca}$ & U \\
\hline WT_>50_B1_CB_1 rep. 1 & $<5$ & $<5$ & 27.08 & $<5$ & 52.34 & 10510.00 & 353.40 & $<5$ & 29.07 & $<5$ & 41.32 & $<5$ & 22920.00 & 3117.00 \\
\hline WT_>50_B1_CB_1 rep. 2 & $<5$ & $<5$ & 5.00 & $<5$ & 5.00 & 4741.00 & 255.30 & $<5$ & 5.00 & $<5$ & 43.25 & $<5$ & 22170.00 & 3392.00 \\
\hline WT_>50_B1_CB_1 rep. 3 & NS & NS & NS & NS & NS & NS & NS & NS & NS & NS & NS & NS & NS & NS \\
\hline Average & $<5$ & $<5$ & 16.04 & $<5$ & 28.67 & 7625.50 & 304.35 & $<5$ & 17.04 & $<5$ & 42.29 & $<5$ & 22545.00 & 3254.50 \\
\hline St dev & * & * & 10.52 & * & 33.47 & 4079.30 & 69.37 & * & 17.02 & * & 1.36 & * & 530.33 & 194.45 \\
\hline$\%$ St Dev & * & * & 65.59 & * & 116.76 & 53.50 & 22.79 & * & 99.91 & * & 3.23 & * & 2.35 & 5.97 \\
\hline WT_>50_B2_CB_1 rep. 1 & $<5$ & $<5$ & 43.32 & $<5$ & 69.35 & 10760.00 & 533.90 & $<5$ & $<5$ & $<5$ & $<5$ & $<5$ & 36770.00 & 4041.00 \\
\hline WT_>50_B2_CB_1 rep. 2 & NS & NS & NS & NS & NS & NS & NS & NS & NS & NS & NS & NS & NS & NS \\
\hline WT_>50_B2_CB_1 rep. 3 & NS & NS & NS & NS & NS & NS & NS & NS & NS & NS & NS & NS & NS & NS \\
\hline Average & $<5$ & $<5$ & 43.32 & $<5$ & 69.35 & 10760.00 & 533.90 & $<5$ & $<5$ & $<5$ & $<5$ & $<5$ & 36770.00 & 4041.00 \\
\hline St dev & * & * & 43.32 & * & 69.35 & 10760.00 & 533.90 & * & * & * & * & * & 36770.00 & 4041.00 \\
\hline$\%$ St Dev & * & * & 100.00 & * & 100.00 & 100.00 & 100.00 & * & * & * & * & * & 100.00 & 100.00 \\
\hline WT_>50_B3_CB_1 rep. 1 & $<5$ & 21.20 & 34.12 & $<5$ & 48.35 & 8300.00 & 422.50 & $<5$ & 29.78 & $<5$ & $<5$ & $<5$ & 35770.00 & 3994.00 \\
\hline WT_>50_B3_CB_1 rep. 2 & $<5$ & $<5$ & 35.26 & $<5$ & 56.57 & 10630.00 & 456.70 & $<5$ & 32.37 & $<5$ & $<5$ & $<5$ & 34850.00 & 4045.00 \\
\hline WT_>50_B3_CB_1 rep. 3 & NS & NS & NS & NS & NS & NS & NS & NS & NS & NS & NS & NS & NS & NS \\
\hline Average & $<5$ & 21.20 & 34.69 & $<5$ & 52.46 & 9465.00 & 439.60 & $<5$ & 31.08 & $<5$ & $<5$ & $<5$ & 35310.00 & 4019.50 \\
\hline St dev & * & * & 0.81 & * & 5.81 & 1647.56 & 24.18 & * & 1.83 & * & * & * & 650.54 & 36.06 \\
\hline$\%$ St Dev & * & * & 2.32 & * & 11.08 & 17.41 & 5.50 & * & 5.89 & * & * & * & 1.84 & 0.90 \\
\hline WT_>50_B4_CB_1 rep. 1 & $<5$ & $<5$ & 22.21 & $<5$ & 27.20 & 4246.00 & 266.90 & $<5$ & $<5$ & $<5$ & $<5$ & $<5$ & 25110.00 & 2437.00 \\
\hline WT_>50_B4_CB_1 rep. 2 & NS & NS & NS & NS & NS & NS & NS & NS & NS & NS & NS & NS & NS & NS \\
\hline WT_>50_B4_CB_1 rep. 3 & NS & NS & NS & NS & NS & NS & NS & NS & NS & NS & NS & NS & NS & NS \\
\hline Average & $<5$ & $<5$ & 22.21 & $<5$ & 27.20 & 4246.00 & 266.90 & $<5$ & $<5$ & $<5$ & $<5$ & $<5$ & 25110.00 & 2437.00 \\
\hline St dev & * & * & 22.21 & * & 27.20 & 4246.00 & 266.90 & * & * & * & * & * & 25110.00 & 2437.00 \\
\hline \% St Dev & * & * & 100.00 & * & 100.00 & 100.00 & 100.00 & * & * & * & * & * & 100.00 & 100.00 \\
\hline WT_>50_B5_CB_1 rep. 1 & $<5$ & $<5$ & $<5$ & $<5$ & 12.02 & 3250.00 & 94.81 & $<5$ & $<5$ & $<5$ & 11.74 & $<5$ & 9304.00 & 860.10 \\
\hline WT_>50_B5_CB_1 rep. 2 & $<5$ & $<5$ & $<5$ & $<5$ & 14.21 & 3726.00 & 102.00 & $<5$ & $<5$ & $<5$ & 11.43 & $<5$ & 9264.00 & 871.00 \\
\hline WT_>50_B5_CB_1 rep. 3 & $<5$ & $<5$ & $<5$ & $<5$ & 22.59 & 3381.00 & 98.52 & $<5$ & $<5$ & $<5$ & 12.58 & $<5$ & 9333.00 & 890.70 \\
\hline Average & $<5$ & $<5$ & $<5$ & $<5$ & 16.27 & 3452.33 & 98.44 & $<5$ & $<5$ & $<5$ & 11.92 & $<5$ & 9300.33 & 873.93 \\
\hline St dev & * & * & * & * & 5.58 & 245.89 & 3.60 & * & * & * & 0.60 & * & 34.65 & 15.51 \\
\hline \% St Dev & * & * & * & * & 34.28 & 7.12 & 3.65 & * & * & * & 4.99 & * & 0.37 & 1.77 \\
\hline
\end{tabular}




\begin{tabular}{|c|c|c|c|c|c|c|c|c|c|c|c|c|c|c|}
\hline Separation Procedure & \multicolumn{14}{|c|}{ Metals (mg/kg) } \\
\hline & $\mathrm{Pb}$ & $\mathrm{Cr}$ & $\mathrm{Cu}$ & $\mathrm{Ni}$ & $\mathrm{Zn}$ & $\mathrm{Fe}$ & $\mathrm{Mn}$ & Mo & $\mathrm{V}$ & $\mathrm{Sb}$ & W & As & $\mathrm{Ca}$ & $\mathrm{U}$ \\
\hline WT_>50_B6_CB_1 rep. 1 & $<5$ & $<5$ & 11.14 & $<5$ & 13.77 & 3887.00 & 126.00 & $<5$ & 15.99 & $<5$ & $<5$ & $<5$ & 10770.00 & 3578.00 \\
\hline WT_>50_B6_CB_1 rep. 2 & $<5$ & $<5$ & 11.70 & $<5$ & 16.26 & 4618.00 & 134.50 & $<5$ & 17.98 & $<5$ & $<5$ & $<5$ & 10630.00 & 3514.00 \\
\hline WT_>50_B6_CB_1 & $<5$ & $<5$ & 11.38 & $<5$ & 15.34 & 4289.00 & 128.60 & $<5$ & 17.61 & $<5$ & $<5$ & $<5$ & 10560.00 & 3541.00 \\
\hline Average & $<5$ & $<5$ & 11.41 & $<5$ & 15.12 & 4264.67 & 129.70 & $<5$ & 17.19 & $<5$ & $<5$ & $<5$ & 10653.33 & 3544.33 \\
\hline St dev & * & * & 0.28 & * & 1.26 & 366.11 & 4.36 & * & 1.06 & * & * & * & 106.93 & 32.13 \\
\hline$\%$ St Dev & * & * & 2.46 & * & 8.33 & 8.58 & 3.36 & * & 6.16 & * & * & * & 1.00 & 0.91 \\
\hline WT_<50_B1_CB_1 rep. 1 & $<5$ & 18.62 & 31.35 & 16.96 & 63.23 & 14020.00 & 499.50 & $<5$ & 43.96 & $<5$ & $<5$ & $<5$ & 35020.00 & 3099.00 \\
\hline WT_<50_B1_CB_1 & $<5$ & 19.22 & 33.55 & 18.19 & 68.24 & 15160.00 & 523.10 & $<5$ & 46.82 & $<5$ & $<5$ & $<5$ & 35540.00 & 3024.00 \\
\hline WT_<50_B1_CB_1 rep. 3 & $<5$ & 17.28 & 29.74 & 15.36 & 57.27 & 12970.00 & 478.70 & $<5$ & 40.85 & $<5$ & $<5$ & $<5$ & 35030.00 & 3173.00 \\
\hline Average & $<5$ & 18.37 & 31.55 & 16.84 & 62.91 & 14050.00 & 500.43 & $<5$ & 43.88 & $<5$ & $<5$ & $<5$ & 35196.67 & 3098.67 \\
\hline St dev & * & 0.99 & 1.91 & 1.42 & 5.49 & 1095.31 & 22.21 & * & 2.99 & * & * & * & 297.38 & 74.50 \\
\hline$\%$ St Dev & * & 5.41 & 6.06 & 8.43 & 8.73 & 7.80 & 4.44 & * & 6.81 & * & * & * & 0.84 & 2.40 \\
\hline WT_<50_B2_CB_1 rep. 1 & $<5$ & 15.86 & 29.20 & 14.01 & 53.43 & 11210.00 & 448.80 & $<5$ & 36.74 & $<5$ & $<5$ & $<5$ & 34430.00 & 3296.00 \\
\hline WT_<50_B2_CB_1 rep. 2 & $<5$ & 15.78 & 29.85 & 14.05 & 51.83 & 10950.00 & 450.70 & $<5$ & 36.29 & $<5$ & $<5$ & $<5$ & 36190.00 & 3379.00 \\
\hline WT_<50_B2_CB_1 rep. 3 & $<5$ & 18.04 & 32.20 & 16.50 & 60.71 & 13100.00 & 490.70 & $<5$ & 41.07 & $<5$ & $<5$ & $<5$ & 36110.00 & 3293.00 \\
\hline Average & $<5$ & 16.56 & 30.42 & 14.85 & 55.32 & 11753.33 & 463.40 & $<5$ & 38.03 & $<5$ & $<5$ & $<5$ & 35576.67 & 3322.67 \\
\hline St dev & * & 1.28 & 1.58 & 1.43 & 4.73 & 1173.47 & 23.66 & * & 2.64 & * & $*$ & * & 993.85 & 48.81 \\
\hline$\%$ St Dev & * & 7.74 & 5.19 & 9.60 & 8.56 & 9.98 & 5.11 & * & 6.94 & * & * & * & 2.79 & 1.47 \\
\hline WT_<50_B3_CB_1 rep. 1 & 17.89 & 20.65 & 61.56 & 14.13 & 36.50 & 9695.00 & 243.60 & $<5$ & 37.20 & $<5$ & $<5$ & $<5$ & 58430.00 & 6753.00 \\
\hline WT_<50_B3_CB_1 rep. 2 & 15.77 & 22.16 & 62.00 & 14.65 & 37.96 & 10470.00 & 244.30 & $<5$ & 38.89 & $<5$ & $<5$ & $<5$ & 57170.00 & 6509.00 \\
\hline WT_<50_B3_CB_1 rep. 3 & 15.54 & 20.36 & 58.87 & 13.99 & 35.38 & 9758.00 & 234.70 & $<5$ & 36.15 & $<5$ & $<5$ & $<5$ & 56270.00 & 6420.00 \\
\hline Average & 16.40 & 21.06 & 60.81 & 14.26 & 36.61 & 9974.33 & 240.87 & $<5$ & 37.41 & $<5$ & $<5$ & $<5$ & 57290.00 & 6560.67 \\
\hline St dev & 1.30 & 0.97 & 1.69 & 0.35 & 1.29 & 430.41 & 5.35 & * & 1.38 & * & * & * & 1084.99 & 172.41 \\
\hline$\%$ St Dev & 7.90 & 4.59 & 2.79 & 2.44 & 3.53 & 4.32 & 2.22 & * & 3.69 & * & * & * & 1.89 & 2.63 \\
\hline WT_<50_B4_CB_1 rep. 1 & $<5$ & $<5$ & 11.60 & $<5$ & 32.03 & 8328.00 & 206.50 & $<5$ & 20.74 & $<5$ & $<5$ & $<5$ & 18750.00 & 466.20 \\
\hline WT_<50_B4_CB_1 rep. 2 & $<5$ & $<5$ & 11.53 & $<5$ & 31.29 & 8026.00 & 198.80 & $<5$ & 21.35 & $<5$ & $<5$ & $<5$ & 18960.00 & 451.70 \\
\hline WT_<50_B4_CB_1 rep. 3 & $<5$ & $<5$ & 11.45 & $<5$ & 31.58 & 8149.00 & 202.20 & $<5$ & 21.15 & $<5$ & $<5$ & $<5$ & 18870.00 & 463.00 \\
\hline Average & $<5$ & $<5$ & 11.53 & $<5$ & 31.63 & 8167.67 & 202.50 & $<5$ & 21.08 & $<5$ & $<5$ & $<5$ & 18860.00 & 460.30 \\
\hline St dev & * & * & 0.08 & * & 0.37 & 151.86 & 3.86 & * & 0.31 & * & * & * & 105.36 & 7.62 \\
\hline$\%$ St Dev & * & * & 0.65 & * & 1.18 & 1.86 & 1.91 & * & 1.48 & * & * & * & 0.56 & 1.65 \\
\hline WT_<50_B5_CB_1 & $<5$ & $<5$ & 12.58 & $<5$ & 25.62 & 7004.00 & 178.30 & $<5$ & 21.66 & $<5$ & $<5$ & $<5$ & 19520.00 & 1884.00 \\
\hline WT_<50_B5_CB_1 & $<5$ & $<5$ & 13.18 & $<5$ & 28.81 & 8052.00 & 192.60 & $<5$ & 23.95 & $<5$ & $<5$ & $<5$ & 19980.00 & 1879.00 \\
\hline
\end{tabular}




\begin{tabular}{|c|c|c|c|c|c|c|c|c|c|c|c|c|c|c|}
\hline & $\mathrm{Pb}$ & $\mathrm{Cr}$ & $\mathrm{Cu}$ & $\mathrm{Ni}$ & $\mathrm{Zn}$ & $\mathrm{Fe}$ & $\mathrm{Mn}$ & Mo & $\mathrm{v}$ & $\mathrm{Sb}$ & W & As & $\mathrm{Ca}$ & $U$ \\
\hline WT_<50_B5_CB_1 rep. 3 & $<5$ & $<5$ & 13.16 & $<5$ & 28.55 & 7768.00 & 187.30 & $<5$ & 24.56 & $<5$ & $<5$ & $<5$ & 19790.00 & 1864.00 \\
\hline St dev & * & * & 0.34 & * & 1.77 & 542.01 & 7.23 & * & 1.53 & * & * & * & 231.16 & 10.41 \\
\hline$\%$ StDev & * & * & 2.63 & * & 6.40 & 7.12 & 3.89 & * & 6.54 & * & * & * & 1.17 & 0.55 \\
\hline $\begin{array}{ll}\text { WT_<50_B6_CB_1 } & \text { rep. } 1\end{array}$ & 11.43 & $<5$ & 16.95 & $<5$ & $<5$ & 2925.00 & 142.40 & $<5$ & 23.73 & $<5$ & $<5$ & $<5$ & 10140.00 & 6648.00 \\
\hline Average & 11.36 & $<5$ & 17.01 & $<5$ & 10.18 & 3319.00 & 149.00 & $<5$ & 24.10 & $<5$ & $<5$ & $<5$ & 9653.00 & 6481.00 \\
\hline St dev & 0.19 & * & 0.41 & * & 10.18 & 435.12 & 5.72 & * & 0.76 & * & * & * & 459.94 & 351.62 \\
\hline \% St Dev & 1.63 & * & 2.40 & * & 100.00 & 13.11 & 3.84 & * & 3.16 & * & * & * & 4.76 & 5.43 \\
\hline \multicolumn{15}{|l|}{ SEPARATION WATER } \\
\hline WT_<50_B1_CB_1 & $<5$ & $<5$ & $<5$ & $<5$ & $<5$ & $<5$ & $<5$ & $<5$ & $<5$ & $<5$ & 0.95 & $<5$ & 96.34 & 9.74 \\
\hline WT_<50_B2_CB_1 & $<5$ & $<5$ & $<5$ & $<5$ & $<5$ & $<5$ & $<5$ & $<5$ & $<5$ & $<5$ & 0.74 & $<5$ & 55.41 & 7.20 \\
\hline
\end{tabular}


Table E6. DU Garden 5 Water Separation using the Wilfley Table

\begin{tabular}{|c|c|c|c|c|c|c|c|c|c|c|c|c|c|c|}
\hline Separation Procedure & \multicolumn{14}{|c|}{ Metals (mg/kg) } \\
\hline & $\mathrm{Pb}$ & $\mathrm{Cr}$ & $\mathrm{Cu}$ & $\mathrm{Ni}$ & $\mathrm{Zn}$ & $\mathrm{Fe}$ & $\mathrm{Mn}$ & Mo & V & $\mathrm{Sb}$ & W & As & $\mathrm{Ca}$ & $\mathrm{U}$ \\
\hline WT_>50_B1_DG_5 & 42.53 & 46.45 & 38.88 & 18.82 & 36.31 & 8754.00 & 276.70 & $<5$ & 65.45 & $<5$ & 22.67 & $<5$ & NS & 25520.00 \\
\hline WT_>50_B1_DG_5 & 40.69 & 48.15 & 40.54 & 19.47 & 40.89 & 9867.00 & 285.20 & $<5$ & 68.30 & $<5$ & 15.69 & $<5$ & NS & 25370.00 \\
\hline WT_>50_B1_DG_5 & 41.36 & 46.55 & 39.53 & 18.92 & 36.54 & 9326.00 & 285.20 & $<5$ & 66.55 & $<5$ & $<5$ & $<5$ & NS & 25860.00 \\
\hline Average & 41.53 & 47.05 & 39.65 & 19.07 & 37.91 & 9315.67 & 282.37 & $<5$ & 66.77 & $<5$ & 19.18 & $<5$ & & 25583.33 \\
\hline St dev & 0.93 & 0.95 & 0.84 & 0.35 & 2.58 & 556.57 & 4.91 & * & 1.44 & * & 4.94 & * & & 251.06 \\
\hline$\%$ St Dev & 2.24 & 2.03 & 2.11 & 1.84 & 6.81 & 5.97 & 1.74 & * & 2.15 & * & 25.73 & * & & 0.98 \\
\hline WT_>50_B2_DG_5 & 39.07 & 43.45 & 36.44 & 18.03 & 34.23 & 9015.00 & 253.90 & $<5$ & 62.50 & $<5$ & 20.17 & $<5$ & NS & 23520.00 \\
\hline WT_>50_B2_DG_5 rep. 2 & 34.71 & 44.64 & 35.90 & 17.61 & 33.00 & 8337.00 & 248.30 & $<5$ & 62.13 & $<5$ & $<5$ & $<5$ & NS & 23500.00 \\
\hline WT_>50_B2_DG_5 & 39.24 & 44.13 & 35.53 & 17.25 & 33.87 & 8087.00 & 248.00 & $<5$ & 61.91 & $<5$ & 14.20 & $<5$ & NS & 23870.00 \\
\hline Average & 37.67 & 44.07 & 35.96 & 17.63 & 33.70 & 8479.67 & 250.07 & $<5$ & 62.18 & $<5$ & 17.19 & $<5$ & & 23630.00 \\
\hline St dev & 2.57 & 0.60 & 0.46 & 0.39 & 0.63 & 480.17 & 3.32 & * & 0.30 & $*$ & 4.22 & * & & 208.09 \\
\hline$\%$ St Dev & 6.82 & 1.35 & 1.27 & 2.21 & 1.88 & 5.66 & 1.33 & * & 0.48 & * & 24.56 & * & & 0.88 \\
\hline WT_>50_B3_DG_5 & 18.96 & 24.77 & 20.29 & 12.55 & 25.04 & 6988.00 & 199.30 & $<5$ & 35.18 & $<5$ & 13.88 & $<5$ & NS & 11810.00 \\
\hline WT_>50_B3_DG_5 & 17.17 & 26.02 & 19.74 & 12.74 & 26.35 & 6951.00 & 203.20 & $<5$ & 35.28 & $<5$ & 11.87 & $<5$ & NS & 11460.00 \\
\hline WT_>50_B3_DG_5 & 16.69 & 25.63 & 19.86 & 12.90 & 26.45 & 6985.00 & 196.90 & $<5$ & 34.96 & $<5$ & 15.41 & $<5$ & NS & 11590.00 \\
\hline Average & 17.61 & 25.47 & 19.96 & 12.73 & 25.95 & 6974.67 & 199.80 & $<5$ & 35.14 & $<5$ & 13.72 & $<5$ & & 11620.00 \\
\hline St dev & 1.20 & 0.64 & 0.29 & 0.18 & 0.79 & 20.55 & 3.18 & * & 0.16 & * & 1.78 & * & & 176.92 \\
\hline$\%$ St Dev & 6.79 & 2.51 & 1.45 & 1.38 & 3.03 & 0.29 & 1.59 & * & 0.47 & * & 12.94 & * & & 1.52 \\
\hline WT_>50_B4_DG_5 & 20.60 & 27.44 & 20.12 & 14.35 & 24.59 & 7492.00 & 202.40 & $<5$ & 39.30 & $<5$ & $<5$ & $<5$ & NS & 13170.00 \\
\hline WT_>50_B4_DG_5 & 21.19 & 30.37 & 21.22 & 15.56 & 27.10 & 8482.00 & 214.30 & $<5$ & 41.14 & $<5$ & $<5$ & $<5$ & NS & 13640.00 \\
\hline WT_>50_B4_DG_5 & 19.23 & 27.87 & 19.67 & 14.97 & 24.01 & 7055.00 & 198.00 & $<5$ & 37.27 & $<5$ & $<5$ & $<5$ & NS & 12870.00 \\
\hline Average & 20.34 & 28.56 & 20.34 & 14.96 & 25.23 & 7676.33 & 204.90 & $<5$ & 39.24 & $<5$ & $<5$ & $<5$ & & 13226.67 \\
\hline St dev & 1.01 & 1.58 & 0.80 & 0.61 & 1.64 & 731.14 & 8.43 & * & 1.94 & * & * & * & & 388.12 \\
\hline$\%$ St Dev & 4.94 & 5.54 & 3.92 & 4.04 & 6.51 & 9.52 & 4.12 & * & 4.93 & * & * & * & & 2.93 \\
\hline WT_>50_B5_DG_5 & 81.27 & 96.42 & 65.45 & 21.31 & 21.65 & 7719.00 & 199.90 & $<5$ & 135.90 & $<5$ & $<5$ & $<5$ & NS & 59650.00 \\
\hline WT_>50_B5_DG_5 & 79.11 & 93.34 & 65.29 & 22.07 & 23.44 & 7925.00 & 204.90 & $<5$ & 138.10 & $<5$ & $<5$ & $<5$ & NS & 61230.00 \\
\hline WT_>50_B5_DG_5 rep. 3 & 83.67 & 95.55 & 64.93 & 21.05 & 22.21 & 7120.00 & 202.90 & $<5$ & 136.90 & $<5$ & $<5$ & $<5$ & NS & 60590.00 \\
\hline Average & 81.35 & 95.10 & 65.22 & 21.48 & 22.43 & 7588.00 & 202.57 & $<5$ & 136.97 & $<5$ & $<5$ & $<5$ & & 60490.00 \\
\hline St dev & 2.28 & 1.59 & 0.27 & 0.53 & 0.92 & 418.18 & 2.52 & * & 1.10 & $*$ & * & * & & 794.73 \\
\hline$\%$ St Dev & 2.80 & 1.67 & 0.41 & 2.47 & 4.08 & 5.51 & 1.24 & * & 0.80 & * & * & * & & 1.31 \\
\hline
\end{tabular}




\begin{tabular}{|c|c|c|c|c|c|c|c|c|c|c|c|c|c|c|}
\hline Separation Procedure & \multicolumn{14}{|c|}{ Metals (mg/kg) } \\
\hline & $\mathrm{Pb}$ & $\mathrm{Cr}$ & $\mathrm{Cu}$ & $\mathrm{Ni}$ & $\mathrm{Zn}$ & $\mathrm{Fe}$ & $\mathrm{Mn}$ & Mo & $\mathrm{V}$ & $\mathrm{Sb}$ & W & As & $\mathrm{Ca}$ & $\mathrm{U}$ \\
\hline WT_>50_B6_DG_5 & 348.20 & 231.40 & 457.00 & $<5$ & $<5$ & 5352.00 & 219.70 & $<5$ & 405.90 & $<5$ & $<5$ & $<5$ & NS & 258200.00 \\
\hline WT_>50_B6_DG_5 & 358.00 & 221.60 & 447.70 & $<5$ & $<5$ & 5048.00 & 215.90 & $<5$ & 388.40 & $<5$ & $<5$ & $<5$ & NS & 252800.00 \\
\hline WT_>50_B6_DG_5 & 353.80 & 231.60 & 453.20 & $<5$ & $<5$ & 4849.00 & 217.40 & $<5$ & 395.60 & $<5$ & $<5$ & $<5$ & NS & 258200.00 \\
\hline Average & 353.33 & 228.20 & 452.63 & $<5$ & $<5$ & 5083.00 & 217.67 & $<5$ & 396.63 & $<5$ & $<5$ & $<5$ & & 256400.00 \\
\hline St dev & 4.92 & 5.72 & 4.68 & * & $*$ & 253.32 & 1.91 & * & 8.80 & $*$ & * & $*$ & & 3117.69 \\
\hline$\%$ St Dev & 1.39 & 2.51 & 1.03 & * & * & 4.98 & 0.88 & * & 2.22 & * & * & * & & 1.22 \\
\hline WT_>50_B7_DG_5 & $<5$ & $<5$ & $<5$ & $<5$ & $<5$ & 1606.00 & $<5$ & $<5$ & $<5$ & $<5$ & $<5$ & $<5$ & NS & 46300.00 \\
\hline WT_>50_B7_DG_5 & NR & NR & NR & NR & NR & NR & NR & NR & NR & NR & NR & NR & NS & NR \\
\hline WT_>50_B7_DG_5 & NR & $\mathrm{NR}$ & NR & NR & NR & NR & NR & NR & NR & NR & NR & NR & NS & NR \\
\hline Average & $<5$ & $<5$ & $<5$ & $<5$ & $<5$ & 1606.00 & $<5$ & $<5$ & $<5$ & $<5$ & $<5$ & $<5$ & & 46300.00 \\
\hline St dev & * & * & * & * & * & & * & * & * & * & * & * & & \\
\hline$\%$ St Dev & * & * & * & * & * & & * & * & $*$ & * & * & * & & \\
\hline WT_<50_B1_DG_5 & 25.17 & 28.76 & 24.90 & 13.73 & 29.98 & 6879.00 & 211.50 & $<5$ & 41.08 & $<5$ & 13.60 & $<5$ & NS & 14410.00 \\
\hline WT_<50_B1_DG_5 & 25.13 & 29.89 & 26.33 & 13.94 & 31.81 & 7286.00 & 208.90 & $<5$ & 40.20 & $<5$ & 10.64 & $<5$ & NS & 14380.00 \\
\hline WT_<50_B1_DG_5 & 24.99 & 28.59 & 24.66 & 13.51 & 29.90 & 6502.00 & 203.80 & $<5$ & 39.51 & $<5$ & $<5$ & $<5$ & NS & 14410.00 \\
\hline Average & 25.10 & 29.08 & 25.30 & 13.73 & 30.56 & 6889.00 & 208.07 & $<5$ & 40.26 & $<5$ & 12.12 & $<5$ & & 14400.00 \\
\hline St dev & 0.09 & 0.71 & 0.90 & 0.22 & 1.08 & 392.10 & 3.92 & * & 0.79 & * & 2.09 & * & & 17.32 \\
\hline$\%$ St Dev & 0.38 & 2.43 & 3.57 & 1.57 & 3.53 & 5.69 & 1.88 & * & 1.95 & * & 17.27 & * & & 0.12 \\
\hline WT_<50_B2_A_DG_5 rep. 1 & 21.14 & 26.12 & 23.19 & 13.50 & 28.21 & 7084.00 & 217.70 & $<5$ & 36.13 & $<5$ & 10.90 & $<5$ & NS & 12810.00 \\
\hline WT_<50_B2_A_DG_5 rep. 2 & 21.35 & 27.60 & 23.55 & 14.09 & 29.48 & 7372.00 & 227.10 & $<5$ & 36.56 & $<5$ & 12.01 & $<5$ & NS & 12940.00 \\
\hline WT_<50_B2_A_DG_5 rep. 3 & 21.84 & 25.83 & 22.76 & 13.05 & 29.32 & 6530.00 & 216.60 & $<5$ & 35.80 & $<5$ & $<5$ & $<5$ & NS & 12770.00 \\
\hline Average & 21.44 & 26.52 & 23.17 & 13.55 & 29.00 & 6995.33 & 220.47 & $<5$ & 36.16 & $<5$ & 11.46 & $<5$ & & 12840.00 \\
\hline St dev & 0.36 & 0.95 & 0.40 & 0.52 & 0.69 & 427.95 & 5.77 & * & 0.38 & * & 0.78 & * & & 88.88 \\
\hline$\%$ St Dev & 1.68 & 3.58 & 1.71 & 3.85 & 2.38 & 6.12 & 2.62 & * & 1.05 & $*$ & 6.85 & * & & 0.69 \\
\hline WT_<50_B2_B_DG_5 rep.1 & $<5$ & 10.15 & 15.81 & 10.11 & 34.21 & 8111.00 & 255.20 & $<5$ & 19.73 & $<5$ & 12.30 & $<5$ & NS & 1270.00 \\
\hline WT_<50_B2_B_DG_5 rep. 2 & $<5$ & 11.28 & 17.33 & 11.54 & 40.90 & 9322.00 & 276.30 & $<5$ & 22.93 & $<5$ & 13.35 & $<5$ & NS & 1204.00 \\
\hline WT_<50_B2_B_DG_5 rep. 3 & $<5$ & 10.78 & 16.63 & 10.57 & 39.55 & 8722.00 & 266.80 & $<5$ & 21.13 & $<5$ & 17.39 & $<5$ & NS & 1216.00 \\
\hline Average & $<5$ & 10.74 & 16.59 & 10.74 & 38.22 & 8718.33 & 266.10 & $<5$ & 21.26 & $<5$ & 14.35 & $<5$ & & 1230.00 \\
\hline St dev & * & 0.57 & 0.76 & 0.73 & 3.54 & 605.51 & 10.57 & * & 1.60 & * & 2.69 & * & & 35.16 \\
\hline \% St Dev & * & 5.27 & 4.59 & 6.80 & 9.26 & 6.95 & 3.97 & * & 7.54 & * & 18.73 & * & & 2.86 \\
\hline WT_<50_B3_DG_5 & 17.70 & 24.08 & 19.21 & 11.49 & 24.83 & 5718.00 & 189.60 & $<5$ & 29.83 & $<5$ & 10.27 & $<5$ & NS & 10970.00 \\
\hline WT_<50_B3_DG_5 rep. 2 & 19.26 & 23.41 & 19.67 & 13.04 & 26.67 & 6240.00 & 200.60 & $<5$ & 30.28 & $<5$ & 5.00 & $<5$ & NS & 10860.00 \\
\hline
\end{tabular}




\begin{tabular}{|c|c|c|c|c|c|c|c|c|c|c|c|c|c|c|}
\hline Separation Procedure & \multicolumn{14}{|c|}{ Metals (mg/kg) } \\
\hline & $\mathrm{Pb}$ & $\mathrm{Cr}$ & $\mathrm{Cu}$ & $\mathrm{Ni}$ & $\mathrm{Zn}$ & $\mathrm{Fe}$ & $\mathrm{Mn}$ & Mo & V & $\mathrm{Sb}$ & W & As & $\mathrm{Ca}$ & $\mathrm{U}$ \\
\hline WT_<50_B3_DG_5 & 19.69 & 22.41 & 19.38 & 11.97 & 24.53 & 5942.00 & 194.90 & $<5$ & 30.55 & $<5$ & 5.00 & $<5$ & NS & 11000.00 \\
\hline Average & 18.88 & 23.30 & 19.42 & 12.17 & 25.34 & 5966.67 & 195.03 & $<5$ & 30.22 & $<5$ & 6.76 & $<5$ & & 10943.33 \\
\hline St dev & 1.05 & 0.84 & 0.23 & 0.79 & 1.16 & 261.87 & 5.50 & * & 0.36 & * & 3.04 & * & & 73.71 \\
\hline$\%$ St Dev & 5.55 & 3.61 & 1.20 & 6.52 & 4.57 & 4.39 & 2.82 & * & 1.20 & * & 45.03 & * & & 0.67 \\
\hline WT_<50_B4_DG_5 & 10.81 & 15.67 & 12.75 & $<5$ & 18.73 & 4853.00 & 154.00 & $<5$ & 17.73 & $<5$ & 10.46 & $<5$ & NS & 6371.00 \\
\hline WT_<50_B4_DG_5 & 10.55 & 15.41 & 12.44 & $<5$ & 17.40 & 4674.00 & 151.40 & $<5$ & 18.31 & $<5$ & 13.14 & $<5$ & NS & 6372.00 \\
\hline WT_<50_B4_DG_5 & $<5$ & 14.94 & 12.56 & $<5$ & 18.03 & 4464.00 & 150.40 & $<5$ & 18.47 & $<5$ & 11.78 & $<5$ & NS & 6494.00 \\
\hline Average & 10.68 & 15.34 & 12.58 & $<5$ & 18.05 & 4663.67 & 151.93 & $<5$ & 18.17 & $<5$ & 11.79 & $<5$ & & 6412.33 \\
\hline St dev & 0.18 & 0.37 & 0.16 & * & 0.67 & 194.71 & 1.86 & * & 0.39 & * & 1.34 & * & & 70.73 \\
\hline$\%$ St Dev & 1.72 & 2.41 & 1.24 & * & 3.69 & 4.17 & 1.22 & * & 2.14 & $*$ & 11.36 & $*$ & & 1.10 \\
\hline WT_<50_B5_DG_5 & 24.27 & 27.73 & 20.61 & 5.00 & 14.98 & 3952.00 & 131.80 & $<5$ & 36.46 & $<5$ & 14.83 & $<5$ & NS & 16540.00 \\
\hline WT_<50_B5_DG_5 & 22.70 & 29.50 & 21.28 & 10.82 & 23.90 & 4609.00 & 141.80 & $<5$ & 38.12 & $<5$ & 10.10 & $<5$ & NS & 16180.00 \\
\hline WT_<50_B5_DG_5 & 23.19 & 29.64 & 20.90 & 5.00 & 16.63 & 4447.00 & 136.40 & $<5$ & 36.66 & $<5$ & 12.32 & $<5$ & NS & 16230.00 \\
\hline Average & 23.39 & 28.96 & 20.93 & 6.94 & 18.50 & 4336.00 & 136.67 & $<5$ & 37.08 & $<5$ & 12.42 & $<5$ & & 16316.67 \\
\hline St dev & 0.80 & 1.06 & 0.34 & 3.36 & 4.75 & 342.28 & 5.01 & * & 0.91 & * & 2.37 & * & & 195.02 \\
\hline \% St Dev & 3.43 & 3.68 & 1.61 & 48.42 & 25.65 & 7.89 & 3.66 & * & 2.44 & * & 19.06 & * & & 1.20 \\
\hline WT_<50_B6_DG_5 & 231.90 & 145.90 & 282.60 & $<5$ & $<5$ & 7450.00 & 165.60 & $<5$ & 256.00 & $<5$ & $<5$ & $<5$ & NS & 164300.00 \\
\hline WT_<50_B6_DG_5 & 213.00 & 148.50 & 273.00 & $<5$ & $<5$ & 8036.00 & 165.50 & $<5$ & 254.40 & $<5$ & $<5$ & $<5$ & NS & 158400.00 \\
\hline WT_<50_B6_DG_5 & 232.90 & 147.10 & 277.40 & $<5$ & $<5$ & 7475.00 & 167.30 & $<5$ & 253.40 & $<5$ & $<5$ & $<5$ & NS & 162500.00 \\
\hline Average & 225.93 & 147.17 & 277.67 & $<5$ & $<5$ & 7653.67 & 166.13 & $<5$ & 254.60 & $<5$ & $<5$ & $<5$ & & 161733.33 \\
\hline St dev & 11.21 & 1.30 & 4.81 & * & * & 331.35 & 1.01 & * & 1.31 & * & * & $*$ & & 3023.79 \\
\hline$\%$ St Dev & 4.96 & 0.88 & 1.73 & * & * & 4.33 & 0.61 & * & 0.52 & * & * & $*$ & & 1.87 \\
\hline WT_<50_B7_DG_5 & $<5$ & $<5$ & $<5$ & $<5$ & $<5$ & 9352.00 & 233.00 & $<5$ & $<5$ & $<5$ & $<5$ & $<5$ & NS & 2846.00 \\
\hline WT_<50_B7_DG_5 & NR & NR & NR & NR & NR & NR & NR & NR & NR & NR & NR & NR & NS & NR \\
\hline WT_<50_B7_DG_5 rep. 3 & NR & $\mathrm{NR}$ & NR & NR & NR & NR & NR & NR & NR & NR & NR & NR & NS & NR \\
\hline Average & $<5$ & $<5$ & $<5$ & $<5$ & $<5$ & 9352.00 & 233.00 & $<5$ & $<5$ & $<5$ & $<5$ & $<5$ & & 2846.00 \\
\hline St dev & * & $*$ & * & $*$ & * & & & * & $*$ & $*$ & * & $*$ & & \\
\hline$\%$ St Dev & * & * & * & * & * & & & * & * & * & * & * & & \\
\hline Water Results & $\mathrm{Pb}$ & $\mathrm{Cr}$ & $\mathrm{Cu}$ & $\mathrm{Ni}$ & $\mathrm{Zn}$ & $\mathrm{Fe}$ & $\mathrm{Mn}$ & Mo & $\mathrm{V}$ & $\mathrm{Sb}$ & W & As & $\mathrm{Ca}$ & U \\
\hline WT_DG_5_<50_B2 & $<5$ & $<5$ & $<5$ & $<5$ & $<5$ & $<5$ & $<5$ & $<5$ & $<5$ & $<5$ & 0.16 & $<5$ & NS & 7.97 \\
\hline
\end{tabular}




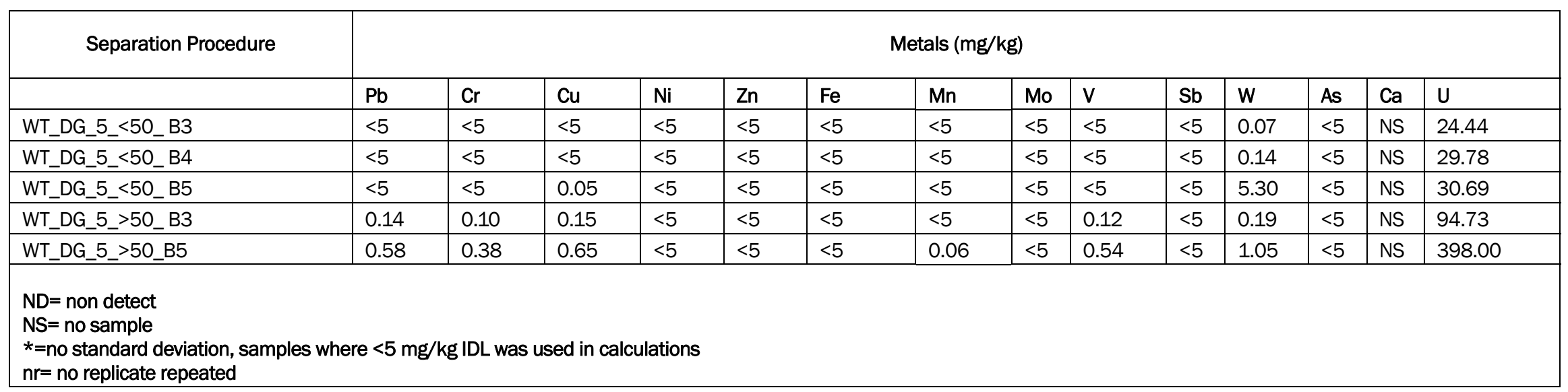


Table E7. Range 20-1 Water Separation using the Wilfley Table

\begin{tabular}{|c|c|c|c|c|c|c|c|c|c|c|c|c|c|c|c|}
\hline \multicolumn{2}{|c|}{ Separation Procedure } & \multicolumn{14}{|c|}{ Metals (mg/kg) } \\
\hline & & $\mathrm{Pb}$ & $\mathrm{Cr}$ & $\mathrm{Cu}$ & $\mathrm{Ni}$ & $\mathrm{Zn}$ & $\mathrm{Fe}$ & $\mathrm{Mn}$ & Mo & V & $\mathrm{Sb}$ & W & As & $\mathrm{Ca}$ & U \\
\hline WT_>50_B1_20_1_ & rep. 1 & $<5$ & $<5$ & 38.85 & $<5$ & 45.79 & 9971.00 & 240.50 & $<5$ & 35.41 & $<5$ & $<5$ & $<5$ & 62670.00 & 5717.00 \\
\hline WT_>50_B1_20_1_ & rep. 2 & NR & NR & NR & NR & NR & NR & NR & NR & NR & NR & NR & NR & NR & NR \\
\hline WT_>50_B1_20_1_ & rep. 3 & NR & NR & NR & NR & NR & NR & NR & NR & NR & NR & NR & NR & NR & NR \\
\hline Average & & $<5$ & $<5$ & 38.85 & $<5$ & 45.79 & 9971.00 & 240.50 & $<5$ & 35.41 & $<5$ & $<5$ & $<5$ & 62670.00 & 5717.00 \\
\hline \multicolumn{16}{|l|}{ St dev } \\
\hline \multicolumn{16}{|l|}{$\%$ St Dev } \\
\hline WT_>50_B2_20_1_ & rep. 1 & $<5$ & $<5$ & 36.19 & $<5$ & 46.92 & 8823.00 & 235.20 & $<5$ & 31.43 & $<5$ & $<5$ & $<5$ & 90190.00 & 3423.00 \\
\hline WT_>50_B2_20_1_ & rep. 2 & $<5$ & $<5$ & 37.01 & $<5$ & 46.74 & 8079.00 & 229.40 & $<5$ & 30.69 & $<5$ & $<5$ & $<5$ & 90030.00 & 3364.00 \\
\hline WT_>50_B2_20_1_ & rep. 3 & $<5$ & $<5$ & 36.78 & $<5$ & 49.01 & 8922.00 & 238.30 & $<5$ & 30.80 & $<5$ & $<5$ & $<5$ & 92080.00 & 3385.00 \\
\hline Average & & $<5$ & $<5$ & 36.66 & $<5$ & 47.56 & 8608.00 & 234.30 & $<5$ & 30.97 & $<5$ & $<5$ & $<5$ & 90766.67 & 3390.67 \\
\hline St dev & & * & * & 0.42 & * & 1.26 & 460.79 & 4.52 & * & 0.40 & * & * & * & 1140.19 & 29.91 \\
\hline$\%$ St Dev & & * & * & 1.15 & * & 2.65 & 5.35 & 1.93 & * & 1.29 & * & * & * & 1.26 & 0.88 \\
\hline WT_>50_B3_20_1_ & rep. 1 & 14.27 & 11.92 & 37.60 & 11.51 & 33.10 & 7242.00 & 203.20 & $<5$ & 25.57 & $<5$ & $<5$ & $<5$ & 46400.00 & 1883.00 \\
\hline WT_>50_B3_20_1_ & rep. 2 & 11.63 & $<5$ & 35.91 & $<5$ & 26.34 & 5584.00 & 182.80 & $<5$ & 23.11 & $<5$ & $<5$ & $<5$ & 46090.00 & 1914.00 \\
\hline WT_>50_B3_20_1_ & rep. 3 & 14.89 & 10.13 & 37.51 & 10.26 & 27.65 & 5768.00 & 185.20 & $<5$ & 23.17 & $<5$ & $<5$ & $<5$ & 45820.00 & 1900.00 \\
\hline Average & & 13.60 & 11.03 & 37.01 & 10.89 & 29.03 & 6198.00 & 190.40 & $<5$ & 23.95 & $<5$ & $<5$ & $<5$ & 46103.33 & 1899.00 \\
\hline St dev & & 1.73 & 1.27 & 0.95 & 0.88 & 3.59 & 908.80 & 11.15 & * & 1.40 & * & * & * & 290.23 & 15.52 \\
\hline$\%$ St Dev & & 12.73 & 11.48 & 2.57 & 8.12 & 12.35 & 14.66 & 5.86 & * & 5.86 & * & * & * & 0.63 & 0.82 \\
\hline WT_>50_B4_20_1_ & rep. 1 & 10.01 & $<5$ & 34.00 & $<5$ & 17.24 & 4565.00 & 172.90 & $<5$ & 18.30 & $<5$ & $<5$ & $<5$ & 29450.00 & 1794.00 \\
\hline WT_>50_B4_20_1_ & rep. 2 & 11.19 & $<5$ & 36.79 & $<5$ & 19.02 & 4902.00 & 182.70 & $<5$ & 19.73 & $<5$ & $<5$ & $<5$ & 30990.00 & 1875.00 \\
\hline WT_>50_B4_20_1_ & rep. 3 & 10.93 & $<5$ & 37.18 & $<5$ & 21.15 & 5475.00 & 189.80 & $<5$ & 20.09 & $<5$ & $<5$ & $<5$ & 30700.00 & 1857.00 \\
\hline Average & & 10.71 & $<5$ & 35.99 & $<5$ & 19.14 & 4980.67 & 181.80 & $<5$ & 19.37 & $<5$ & $<5$ & $<5$ & 30380.00 & 1842.00 \\
\hline St dev & & 0.62 & * & 1.73 & * & 1.96 & 460.07 & 8.49 & * & 0.95 & * & * & * & 818.35 & 42.53 \\
\hline$\%$ St Dev & & 5.79 & * & 4.82 & * & 10.23 & 9.24 & 4.67 & * & 4.89 & * & * & * & 2.69 & 2.31 \\
\hline WT_>50_B5_20_1_ & rep. 1 & 28.52 & 23.67 & 43.95 & 13.42 & 23.59 & 7478.00 & 202.90 & $<5$ & 44.56 & $<5$ & $<5$ & $<5$ & 21680.00 & 13740.00 \\
\hline WT_>50_B5_20_1_ & rep. 2 & 29.07 & 24.74 & 45.39 & 14.00 & 24.04 & 7700.00 & 197.10 & $<5$ & 46.09 & $<5$ & $<5$ & $<5$ & 20810.00 & 14060.00 \\
\hline WT_>50_B5_20_1_ & rep. 3 & 31.08 & 24.46 & 45.14 & 13.70 & 23.76 & 7713.00 & 200.80 & $<5$ & 45.61 & $<5$ & $<5$ & $<5$ & 20320.00 & 14200.00 \\
\hline Average & & 29.56 & 24.29 & 44.83 & 13.71 & 23.80 & 7630.33 & 200.27 & $<5$ & 45.42 & $<5$ & $<5$ & $<5$ & 20936.67 & 14000.00 \\
\hline St dev & & 1.35 & 0.55 & 0.77 & 0.29 & 0.23 & 132.08 & 2.94 & * & 0.78 & * & * & * & 688.79 & 235.80 \\
\hline \% St Dev & & 4.56 & 2.28 & 1.72 & 2.12 & 0.95 & 1.73 & 1.47 & * & 1.72 & * & * & * & 3.29 & 1.68 \\
\hline
\end{tabular}




\begin{tabular}{|c|c|c|c|c|c|c|c|c|c|c|c|c|c|c|}
\hline Separation Procedure & \multicolumn{14}{|c|}{ Metals (mg/kg) } \\
\hline & $\mathrm{Pb}$ & $\mathrm{Cr}$ & $\mathrm{Cu}$ & $\mathrm{Ni}$ & $\mathrm{Zn}$ & $\mathrm{Fe}$ & $\mathrm{Mn}$ & Mo & $\mathrm{V}$ & $\mathrm{Sb}$ & W & As & $\mathrm{Ca}$ & $U$ \\
\hline WT_>50_B6_20_1_ & 59.94 & 42.32 & 78.20 & 16.29 & 23.52 & 9431.00 & 254.20 & $<5$ & 82.36 & $<5$ & $<5$ & $<5$ & 17330.00 & 30160.00 \\
\hline WT_>50_B6_20_1_ & 57.04 & 40.92 & 77.80 & 16.14 & 23.44 & 9401.00 & 247.50 & $<5$ & 80.04 & $<5$ & $<5$ & $<5$ & 17200.00 & 29990.00 \\
\hline WT_>50_B6_20_1_ & 58.48 & 43.26 & 79.52 & 17.41 & 25.98 & 11590.00 & 267.10 & $<5$ & 87.00 & $<5$ & $<5$ & $<5$ & 17500.00 & 30290.00 \\
\hline Average & 58.49 & 42.17 & 78.51 & 16.61 & 24.31 & 10140.67 & 256.27 & $<5$ & 83.13 & $<5$ & $<5$ & $<5$ & 17343.33 & 30146.67 \\
\hline St dev & 1.45 & 1.18 & 0.90 & 0.69 & 1.44 & 1255.25 & 9.96 & * & 3.54 & $*$ & * & $*$ & 150.44 & 150.44 \\
\hline$\%$ St Dev & 2.48 & 2.79 & 1.15 & 4.18 & 5.94 & 12.38 & 3.89 & * & 4.26 & * & * & * & 0.87 & 0.50 \\
\hline WT_<50_B1_20_1_ & 50.10 & 18.66 & 60.30 & 13.07 & 33.64 & 8380.00 & 236.00 & $<5$ & 31.33 & $<5$ & 5.00 & $<5$ & 64050.00 & 6099.00 \\
\hline WT_<50_B1_20_1_ & 22.61 & 18.08 & 60.45 & 12.93 & 32.76 & 8197.00 & 235.60 & $<5$ & 30.83 & $<5$ & 5.00 & $<5$ & 62730.00 & 6101.00 \\
\hline WT_<50_B1_20_1_ & 14.84 & 18.34 & 60.82 & 13.10 & 32.62 & 8127.00 & 237.70 & $<5$ & 31.42 & $<5$ & 22.30 & $<5$ & 64190.00 & 6088.00 \\
\hline Average & 29.18 & 18.36 & 60.52 & 13.03 & 33.01 & 8234.67 & 236.43 & $<5$ & 31.19 & $<5$ & 10.77 & $<5$ & 63656.67 & 6096.00 \\
\hline St dev & 18.53 & 0.29 & 0.27 & 0.09 & 0.55 & 130.64 & 1.12 & * & 0.32 & * & 9.99 & * & 805.56 & 7.00 \\
\hline$\%$ St Dev & 63.48 & 1.58 & 0.44 & 0.70 & 1.68 & 1.59 & 0.47 & * & 1.02 & * & 92.77 & * & 1.27 & 0.11 \\
\hline WT_<50_B2_20_1_ & 14.46 & 24.51 & 41.42 & 21.74 & 87.19 & 17320.00 & 553.30 & $<5$ & 43.84 & $<5$ & $<5$ & $<5$ & 56090.00 & 946.30 \\
\hline WT_<50_B2_20_1_ & 5.00 & 23.90 & 40.51 & 21.28 & 85.35 & 16830.00 & 548.10 & $<5$ & 41.14 & $<5$ & $<5$ & $<5$ & 54810.00 & 943.10 \\
\hline$W T \_<50 \_B 2$ 20_1_ & 5.00 & 23.72 & 40.94 & 21.14 & 84.51 & 16720.00 & 544.80 & $<5$ & 43.00 & $<5$ & $<5$ & $<5$ & 56600.00 & 941.50 \\
\hline Average & 8.15 & 24.04 & 40.96 & 21.39 & 85.68 & 16956.67 & 548.73 & $<5$ & 42.66 & $<5$ & $<5$ & $<5$ & 55833.33 & 943.63 \\
\hline St dev & 5.46 & 0.41 & 0.46 & 0.31 & 1.37 & 319.43 & 4.29 & * & 1.38 & * & * & * & 922.19 & 2.44 \\
\hline \% St Dev & 66.99 & 1.72 & 1.11 & 1.47 & 1.60 & 1.88 & 0.78 & * & 3.24 & * & * & * & 1.65 & 0.26 \\
\hline WT_<50_B3_20_1_ & 13.90 & 15.92 & 57.72 & 11.28 & 26.66 & 6883.00 & 200.30 & $<5$ & 28.44 & $<5$ & $<5$ & $<5$ & 48370.00 & 5834.00 \\
\hline WT_<50_B3_20_1_ & 15.48 & 14.82 & 56.28 & 10.42 & 24.52 & 6031.00 & 189.70 & $<5$ & 27.26 & $<5$ & $<5$ & $<5$ & 47710.00 & 5774.00 \\
\hline WT_<50_B3_20_1_ & 18.18 & 14.80 & 55.86 & 10.15 & 23.73 & 6045.00 & 187.80 & $<5$ & 26.88 & $<5$ & $<5$ & $<5$ & 47500.00 & 5758.00 \\
\hline Average & 15.85 & 15.18 & 56.62 & 10.62 & 24.97 & 6319.67 & 192.60 & $<5$ & 27.53 & $<5$ & $<5$ & $<5$ & 47860.00 & 5788.67 \\
\hline St dev & 2.16 & 0.64 & 0.98 & 0.59 & 1.52 & 487.91 & 6.74 & * & 0.81 & * & * & * & 453.98 & 40.07 \\
\hline$\%$ St Dev & 13.65 & 4.22 & 1.72 & 5.56 & 6.07 & 7.72 & 3.50 & * & 2.96 & * & * & * & 0.95 & 0.69 \\
\hline WT_<50_B4_20_1_ & 10.76 & 12.76 & 47.91 & 10.70 & 24.02 & 6403.00 & 183.30 & $<5$ & 24.56 & $<5$ & $<5$ & $<5$ & 38540.00 & 3507.00 \\
\hline WT_<50_B4_20_1_ & $<5$ & 12.58 & 47.37 & 10.56 & 23.30 & 6241.00 & 184.80 & $<5$ & 23.90 & $<5$ & $<5$ & $<5$ & 37890.00 & 3500.00 \\
\hline WT_<50_B4_20_1_ & 11.75 & 13.48 & 47.60 & 10.72 & 24.17 & 6582.00 & 185.10 & $<5$ & 24.28 & $<5$ & $<5$ & $<5$ & 37260.00 & 3446.00 \\
\hline Average & 11.26 & 12.94 & 47.63 & 10.66 & 23.83 & 6408.67 & 184.40 & $<5$ & 24.25 & $<5$ & $<5$ & $<5$ & 37896.67 & 3484.33 \\
\hline St dev & 0.70 & 0.48 & 0.27 & 0.09 & 0.47 & 170.57 & 0.96 & * & 0.33 & * & * & $*$ & 640.03 & 33.38 \\
\hline \% St Dev & 6.22 & 3.68 & 0.57 & 0.82 & 1.95 & 2.66 & 0.52 & * & 1.37 & * & * & * & 1.69 & 0.96 \\
\hline WT_<50_B5_20_1_ & $<5$ & $<5$ & $<5$ & $<5$ & $<5$ & 6300.00 & 182.50 & $<5$ & $<5$ & $<5$ & $<5$ & $<5$ & 27030.00 & 21470.00 \\
\hline WT_<50_B5_20_1_rep. 2 & $<5$ & $<5$ & $<5$ & $<5$ & $<5$ & 4737.00 & 155.50 & $<5$ & $<5$ & $<5$ & $<5$ & $<5$ & 23360.00 & 18930.00 \\
\hline
\end{tabular}




\begin{tabular}{|c|c|c|c|c|c|c|c|c|c|c|c|c|c|c|}
\hline Separation Procedure & \multicolumn{14}{|c|}{ Metals (mg/kg) } \\
\hline & $\mathrm{Pb}$ & $\mathrm{Cr}$ & $\mathrm{Cu}$ & $\mathrm{Ni}$ & $\mathrm{Zn}$ & $\mathrm{Fe}$ & $\mathrm{Mn}$ & Mo & $\mathrm{V}$ & $\mathrm{Sb}$ & W & As & $\mathrm{Ca}$ & U \\
\hline WT_<50_B5_20_1_ & $<5$ & $<5$ & $<5$ & $<5$ & $<5$ & 4611.00 & 149.60 & $<5$ & $<5$ & $<5$ & $<5$ & $<5$ & 24120.00 & 18560.00 \\
\hline Average & $<5$ & $<5$ & $<5$ & $<5$ & $<5$ & 5216.00 & 162.53 & $<5$ & $<5$ & $<5$ & $<5$ & $<5$ & 24836.67 & 19653.33 \\
\hline St dev & * & * & * & $*$ & * & 940.88 & 17.54 & * & * & * & * & * & 1937.12 & 1584.12 \\
\hline$\%$ St Dev & * & * & $*$ & * & * & 18.04 & 10.79 & $*$ & $*$ & $*$ & * & * & 7.80 & 8.06 \\
\hline WT_<50_B6_20_1_ rep. 1 & 134.20 & $<5$ & 181.40 & $<5$ & $<5$ & 4289.00 & 190.10 & $<5$ & 163.90 & $<5$ & $<5$ & $<5$ & 10990.00 & 87350.00 \\
\hline WT_<50_B6_20_1_ rep. 2 & 147.60 & $<5$ & 193.00 & $<5$ & $<5$ & 2241.00 & 156.60 & $<5$ & 163.10 & $<5$ & $<5$ & $<5$ & 10370.00 & 93450.00 \\
\hline WT_<50_B6_20_1_rep. 3 & 143.70 & $<5$ & 186.00 & $<5$ & $<5$ & 2721.00 & 149.90 & $<5$ & 157.40 & $<5$ & $<5$ & $<5$ & 10190.00 & 89610.00 \\
\hline Average & 141.83 & $<5$ & 186.80 & $<5$ & $<5$ & 3083.67 & 165.53 & $<5$ & 161.47 & $<5$ & $<5$ & $<5$ & 10516.67 & 90136.67 \\
\hline St dev & 6.89 & * & 5.84 & * & * & 1071.08 & 21.54 & * & 3.54 & $*$ & * & * & 419.68 & 3083.92 \\
\hline$\%$ St Dev & 4.86 & * & 3.13 & * & * & 34.73 & 13.01 & * & 2.20 & * & * & * & 3.99 & 3.42 \\
\hline $\begin{array}{l}\text { WATER Samples } \\
(\mathrm{ppm})\end{array}$ & $\mathrm{Pb}$ & $\mathrm{Cr}$ & $\mathrm{Cu}$ & $\mathrm{Ni}$ & $\mathrm{Zn}$ & $\mathrm{Fe}$ & $\mathrm{Mn}$ & Mo & V & $\mathrm{Sb}$ & W & As & $\mathrm{Ca}$ & U \\
\hline WT_>50_B2_20_1_ & $<5$ & $<5$ & $<5$ & $<5$ & $<5$ & $<5$ & $<5$ & $<5$ & $<5$ & $<5$ & 0.22 & $<5$ & 57.18 & 9.57 \\
\hline WT_>50_B3_20_1_ & $<5$ & $<5$ & $<5$ & $<5$ & $<5$ & $<5$ & $<5$ & $<5$ & $<5$ & $<5$ & 0.11 & $<5$ & 92.06 & 13.89 \\
\hline WT_>50_B4_20_1_ & $<5$ & $<5$ & $<5$ & $<5$ & $<5$ & $<5$ & $<5$ & $<5$ & $<5$ & $<5$ & $<5$ & $<5$ & 131.30 & 12.17 \\
\hline WT_>50_B5_20_1_ & 0.33 & 0.21 & 0.46 & $<5$ & $<5$ & $<5$ & $<5$ & $<5$ & 0.43 & $<5$ & $<5$ & $<5$ & 386.10 & 220.50 \\
\hline WT_<50_B1_20_1_ & $<5$ & $<5$ & $<5$ & $<5$ & $<5$ & $<5$ & $<5$ & $<5$ & $<5$ & $<5$ & 0.35 & $<5$ & 71.10 & 12.64 \\
\hline WT_<50_B2_20_1_ & $<5$ & $<5$ & $<5$ & $<5$ & $<5$ & $<5$ & $<5$ & $<5$ & $<5$ & $<5$ & 0.31 & $<5$ & 55.93 & 9.00 \\
\hline WT_<50_B5_20_1_ & 0.12 & 0.09 & 0.17 & $<5$ & $<5$ & $<5$ & $<5$ & $<5$ & 0.16 & $<5$ & 0.23 & $<5$ & 134.00 & 85.17 \\
\hline $\begin{array}{l}\mathrm{ND}=\text { non detect } \\
\mathrm{NS}=\text { no sample } \\
*=\text { no standard deviation, sample } \\
\mathrm{nr}=\text { no replicate performed }\end{array}$ & ere $<5$ & 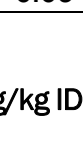 & s used $i$ & 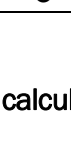 & & & & & & & & & & \\
\hline
\end{tabular}


Table E8. Retention Pond Water Separation using the Wilfley Table

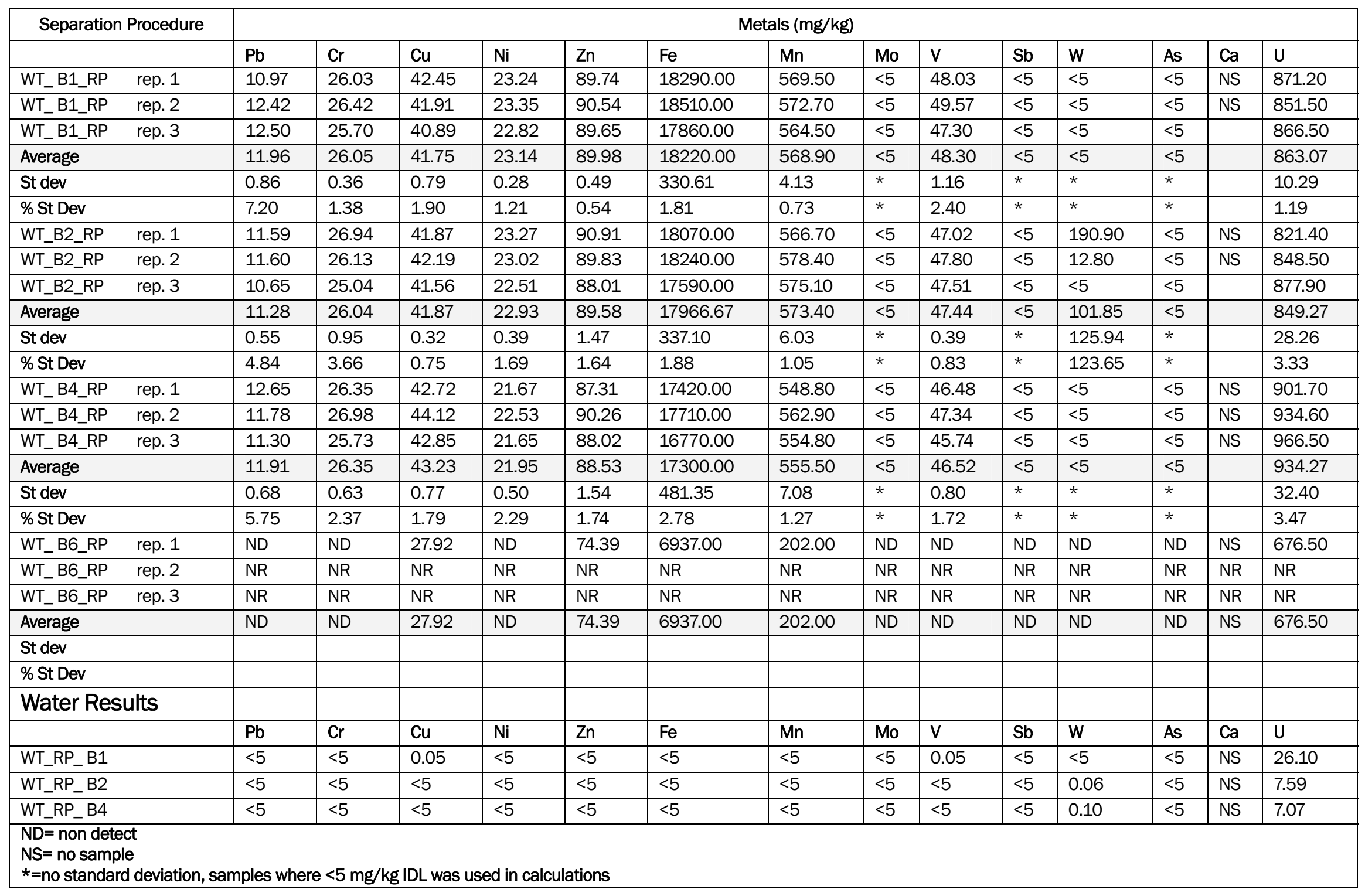




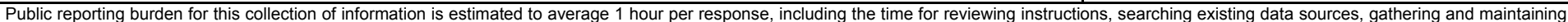

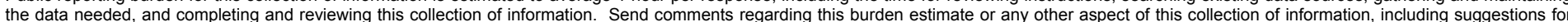

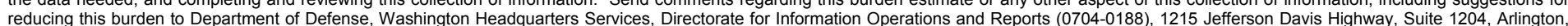

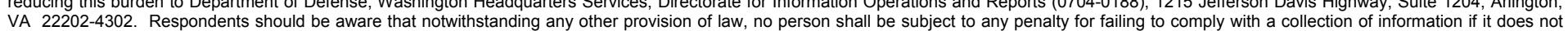
VA 22202-4302. Respondents should be aware that notwithstanding any other provision of law, no person shall be sube
display a currently valid OMB control number. PLEASE DO NOT RETURN YOUR FORM TO THE ABOVE ADDRESS.

\begin{tabular}{l|c}
$\begin{array}{l}\text { 1. REPORT DATE (DD-MM-YYYY) } \\
\text { March } 2009\end{array}$ & $\begin{array}{c}\text { 2. REPORT TYPE } \\
\text { Final report }\end{array}$ \\
\hline
\end{tabular}

\section{TITLE AND SUBTITLE}

Separation of Depleted Uranium from Soil

3. DATES COVERED (From - To)

5a. CONTRACT NUMBER

5b. GRANT NUMBER

5c. PROGRAM ELEMENT NUMBER

5d. PROJECT NUMBER

5e. TASK NUMBER

5f. WORK UNIT NUMBER

8. PERFORMING ORGANIZATION REPORT NUMBER

ERDC/EL TR-09-1

U.S. Army Engineer Research and Development Center

3909 Halls Ferry Road, Vicksburg, MS 39180-6199

ARDEC

Picatinny Arsenal, Building 355

NJ 07806-5008

Applied Research Associates, Inc., Southern Division

119 Monument Place, Vicksburg, MS 39180

9. SPONSORING / MONITORING AGENCY NAME(S) AND ADDRESS(ES)

10. SPONSOR/MONITOR'S ACRONYM(S)

U.S. Army Corps of Engineers

Washington, DC 20314-1000

11. SPONSOR/MONITOR'S REPORT NUMBER(S)

\section{DISTRIBUTION / AVAILABILITY STATEMENT}

Approved for public release; distribution is unlimited.

\section{SUPPLEMENTARY NOTES}

\section{ABSTRACT}

Dry and wet physical separation processes were tested at Yuma Proving Ground to remove depleted uranium (DU) from soil. Four sample locations were tested that had varied uranium concentration, weathering and aging of fired, DU residues. Reduction of soil DU concentration was achieved using simple vibratory or agitated screening techniques. For soils into which the DU had been recently fired, these techniques were successful at removing a large fraction ( $>70$ percent) of the total uranium present (by mass). A heavy liquid separation process based on a water/sodium polytungstate solution was tested. This produced a sinking fraction that contained nearly 100 percent uranium and uranium oxide by mass for the less weathered soils. However, this type of wet separation is not currently practical for field use. A water-based separation process using an angled vibrating table to facilitate gravity transport of separated DU was also tested. This method produced a fraction of concentrated uranium along with fractions of soil particles with reduced densities. However, this process required extensive particle size separation prior to use and produced a contaminated waste stream that required secondary treatment. The extent to which DU and DU residues could be removed from the Yuma soils depended on the extent of soil weathering and corrosion of the DU alloy.

\begin{tabular}{|c|c|c|c|c|c|}
\hline \multicolumn{2}{|l|}{ 15. SUBJECT TERMS } & \multicolumn{2}{|c|}{ Heavy liquid density separation } & \multicolumn{2}{|c|}{ Wet sieve separation } \\
\hline \multicolumn{2}{|l|}{ Depleted uranium } & \multicolumn{2}{|l|}{ Soil separation } & \multicolumn{2}{|c|}{ Wilfley Table } \\
\hline \multicolumn{2}{|l|}{ Dry sieve separation } & \multicolumn{2}{|c|}{ Water/momentum density separation } & \multicolumn{2}{|c|}{ Yuma Proving Ground } \\
\hline \multicolumn{3}{|c|}{ 16. SECURITY CLASSIFICATION OF: } & \multirow[t]{2}{*}{$\begin{array}{l}\text { 17. LIMITATION } \\
\text { OF ABSTRACT }\end{array}$} & \multirow[t]{2}{*}{$\begin{array}{l}\text { 18. NUMBER } \\
\text { OF PAGES }\end{array}$} & $\begin{array}{l}\text { 19a. NAME OF RESPONSIBLE } \\
\text { PERSON }\end{array}$ \\
\hline $\begin{array}{l}\text { a. REPORT } \\
\text { UNCLASSIFIED }\end{array}$ & $\begin{array}{l}\text { b. ABSTRACT } \\
\text { UNCLASSIFIED }\end{array}$ & $\begin{array}{l}\text { c. THIS PAGE } \\
\text { UNCLASSIFIED }\end{array}$ & & & $\begin{array}{l}\text { 19b. TELEPHONE NUMBER (include } \\
\text { area code) }\end{array}$ \\
\hline
\end{tabular}

